\title{
PATTERNS OF CONSOLIDATION
}

in a divided landscape

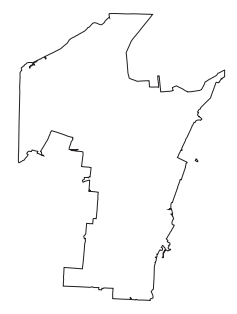

Oliver Syme 
A C K N OW L E D G E M EN T S

Kerstin Thompson, my sincere appreciation for your unwavering diligence, and rationale. Thank you for sharing your time with us this year. I am very grateful for your guidance.

Carles Almoyna, you offered new insight and gave me a lot to consider this year. Thank you for your attention to detail and enthusiasm in studio.

$M \ll D$, without writing a list - thank you for everything you have provided over the years. I would not be in such a position without your kindness, generosity and care.

A 120 point thesis submitted to the School of Architecture and Design, Victoria University of Wellington, in partial fulfilment of the requirements for the degree, Master of Architecture (Professional)

Victoria University of Wellington

February 2017 


\section{A B S T R A C T}

This thesis uses design based research to meet the challenge of urban densification. It proposes an approach for higher density housing development that enhances livability, achieves compactness and responds to a city's unique landscape. To accommodate an increasing amount of people within the city, strategies and experimentation into the density of built form contributing to the urban fabric must be explored. The design based research addresses how improvements can be made upon an existing site through the reconfiguration of built form with an analysis into density, topography, existing natural ecologies and the key components fundamental to a successful urban and public realm.

The project proposes new arrangements of built form on sloped sites that integrate housing, ecology, the street and the broader public realm as a primary driver in urban housing design.

Keywords: urban intensification, public realm, housing, natural ecology, inner city, topograpby 


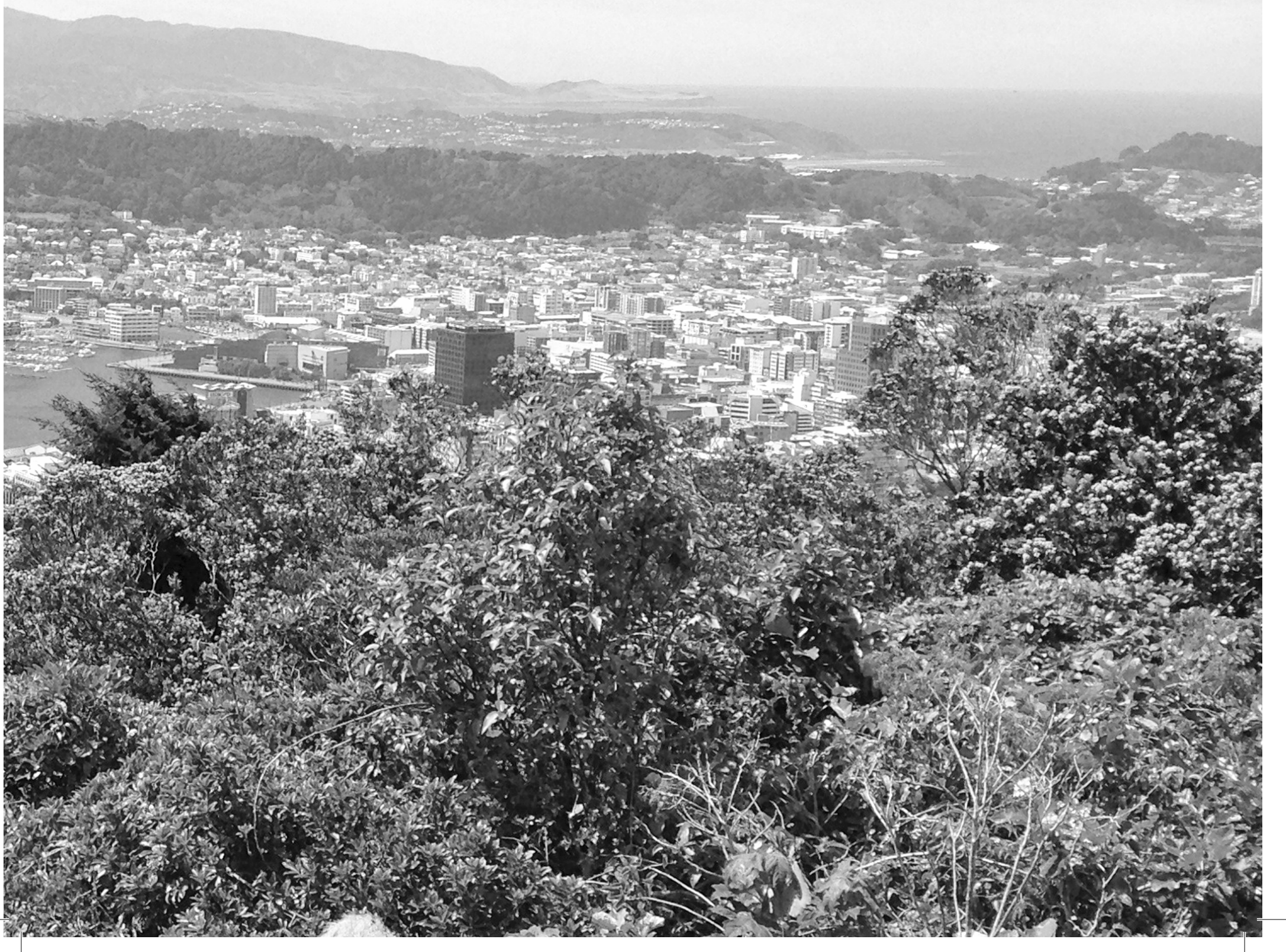




\title{
C ONTENTS
}

\author{
¿ THESIS INTRODUCTION 8 \\ Research discourse and question $\quad 11$ \\ 2.THEORETICAL FRAMEWORK 16 \\ Literary Context 18 \\ Precedent Review 24
}

3.DESIGN \& RESEARCH 50

Site Analysis $\quad 52$

Determined Site 68

Density Analysis $\quad 70$

Topography Analysis I 90

Topograpby Analysis II 98

Defining Territory and Privacy 124

Natural Ecology 136

\$ FINAL DESIGN 152

Conclusion

Thesis References $\quad 174$

Figure List 182 
1 


\title{
THESIS INTRODUCTION
}

\author{
Introducing the context, problem and significance of \\ the research, followed by a brief introduction to the site
}




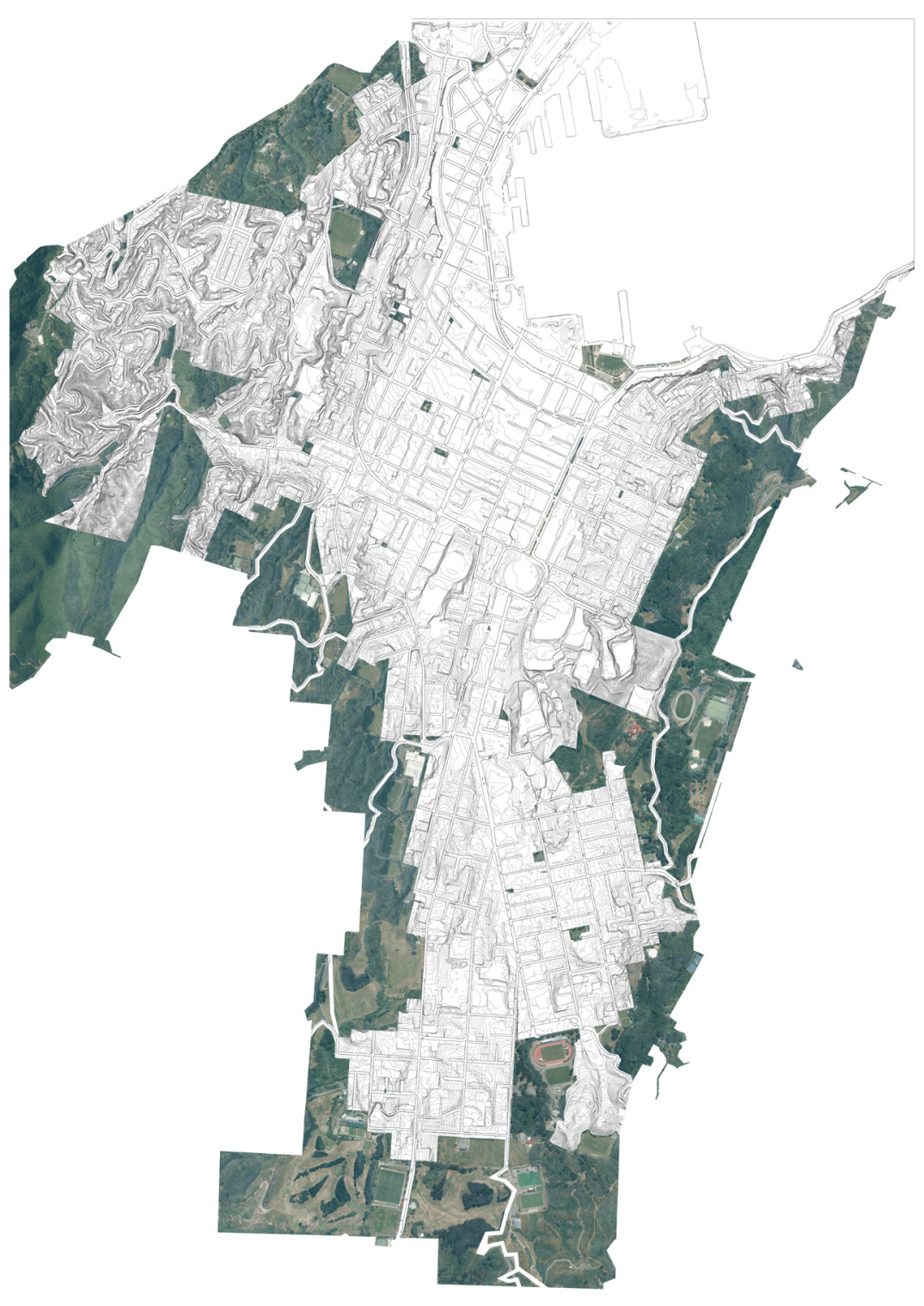




\title{
RESEARCH DISCOURSE
}

\author{
A N I N TRODUCTION
}

\section{P R O B L E M}

\section{$W$}

ellington is remotely located at the south-western tip of the North Island along the Cook Strait, which separates New Zealand's North and South Islands.

The capital city has become densely populated, more so than most other cities in New Zealand due to the restricted amount of land that is available between the harbour and surrounding vegetated hills. The hills form around the inner city to create the capital's town belt reserve. It provides unique edge conditions for the urban fabric by enclosing the city and central suburbs. The topographical condition presents itself as a continuous green sweep of native vegetation and parkland providing an important part of Wellington's landscape and geographical identity.

\section{$<$}

Figure 2 // Wellington aerial; town belt ridges
The centralization between land formations and adjoining harbours create very few open areas to expand. This has resulted in additional development of suburban towns located in the outer city and creates a decentralization of the city as increasing amounts of the population is pushed outwards. As this happens, longer commutes are experienced by residents and the proficiency of a city's urban infrastructure is tested. (Lynch, Kevin)

Rather than make attempts to expand outwards in a decentralized sprawl the existing inner city fabric should first be addressed.

\section{A divided landscape;}

Traditionally urban planning differentiates between landscape and architecture, green space and built form, horizontal and vertical. The approach supports development of each practice independently without inviting the potential of a merge.

This thesis considers the two entities in equal significance and as a hybrid - one entity of built form and the other of landscape. They become mutually dependent and defining, and both combine to influence the public and private realm belonging to the city. 


\section{DESIGN \& RESEARCH O P P ORT U N T Y}

By utilizing the city's direct relationship to the vegetated town belt and terrain there is an opportunity to conduct research and design into the field of urbanism and housing. This tests a denser inner city housing model to the current norm of stand-alone detached dwellings. The design process is derived from urban conditions such as topography, urban public realm and natural ecologies which is solemnly implemented in the existing housing stock. Through research this thesis hypothesises the city would benefit from a more dense urban housing model located around the vegetated ridges of Wellington's town belt. A model that links both built form, landscape and urban design more concisely.

\section{EXISTING S I T E}

This project focuses in a geographically defined area within Wellington. The research strategy selects an existing residential block to generate an investigation of how a new urban housing model could be applied to existing low-density city fabric that consists of mainly single detached dwellings. An existing site is used to propose new arrangements of built form consisting of higher density attached dwellings with a focus on extending the public realm. An existing site means qualitative and quantitative comparisons can be made between the current condition and an alternative solution to measure positive or negative changes in the research and design.

\section{S I G N I F I C A N C E O F R E S E A R C H}

Preparing an alternative for the future; Wellington City's population growth is expected to grow from the current 200,000 to approximately 250,000 over the next 30 years. (Wellington City Council) To counteract urban sprawl occurring in suburbs outside the city and to best utilise the existing infrastructure within, opportunities specific to Wellington are explored. In moving towards a denser urban environment the research becomes significant by addressing how a design with a shared focus between architecture and landscape can improve both components of housing densification and integrate quality public realm.

The vegetated ridges around Wellington's town belt contribute to both city character and ecological resilience by providing a centrally located source of green space. This provides important ecological connectivity to the heart of the city while stemming abroad to wider green networks growing to the city's west, south and eastern regions. In the event this area requires densification the experiments conducted within the thesis design process will help explore how additional dwellings and built form can be achieved. The arrangement of new dwellings is designed to ensure the retention and health of urban ecosystems while enabling vegetation and public space to become more integrated to the city. 


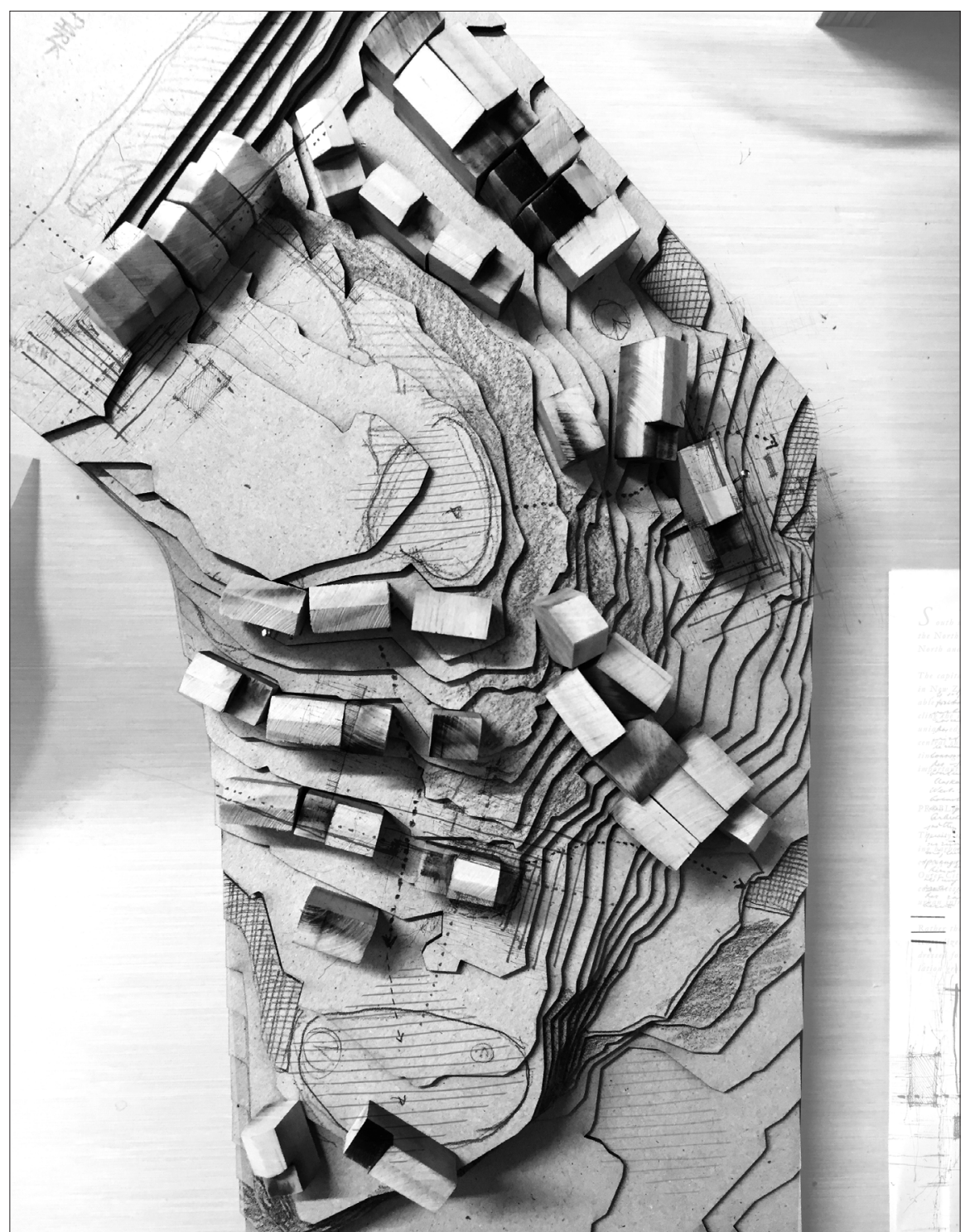

$\wedge$

Figure 3 // 1:200 massing model; linking topography, built form, street connections 


\section{RESEARCH QUESTION}

\& OBJECTIVES

How can the design of higher density housing on sloping sites enhance the public realm, support street activity and integrate with natural ecologies?

In relation to this question, the following objectives were noted;

o Provide a low rise medium density residential model that acts as a transition between high density inner city apartments and low rise low density outer suburban housing.

o Integrate residential built form and landscape with a site's ecology and topography.

o Encourage social interaction through street networks and other transitional spaces that configure positive relations between public, private and common areas.

o Establish a higher quality network of the public realm, and the importance for a close and direct relationship with the street, as the primary driver in urban bousing design. 
2 
THEORETIC AL FR AMEWORK

Chapter containing literary + precedent reviews 


\section{I T E R A R Y C O N T E X T}

This chapter provides an overview of urban design principles and theories that underpin successful public realms; ones that achieve livability especially in denser housing environments. From this overview, design principles are established to guide the subsequent design explorations.

The aims from this review are to distinguish design methods and theory that take precedent over existing principles in order to substantiate and apply additional knowledge to the scope of the thesis research and objectives. 


\section{URBAN CONSOLIDATION \& NEW ORGANISATION OF SPACE}

Keywords: compact city

A compact city has gained global impact as a planning approach for sustainable development with increasing urban population. (Konijnendijk, Cecil) Through densification and compact building, the objectives aim to counteract negative effects of urban sprawl in terms of inefficient land use and related environmental problems. While urban densification has its benefits it can also pose threats to urban green space. Cecil Konijnendijk says that there are challenges during the densification process which requires a provision of urban green space in compact residential and city environments. Loss in quantity of private urban green space can be offset by increased urban green space quality and is referred to by James Byrne as a

"compensation hypothesis".

Dense cities offer positive hope for living lowcarbon lives and can be designed and managed in ways which ensure they remain socially and ecologically resilient. Compactness and density create the conditions in which walking and daily outside living becomes more possible. A livelier, denser and more active streetscape can reduce a pedestrian's perception of distance by directly engaging with their senses as they become more interested in what is happening in the immediate environment around them and less focussed on the act of walking making the trips feel shorter, more manageable and more enjoyable. (Beatley, Timothy. 85)

These spatial cues and factors are attributed to the design of the surrounding buildings and urban environment. Highlighting specific building orientation, street connectivity and layout, and building design (GLC). Also noted, is that surrounding buildings can adversely affect the public realm. Dull building facades and inactive or poorly defined building edges combine to reduce the visual quality of the environment and decrease street legibility. (Bentley. 51).

According to Llewwlyn Davis-Yeang, one of the most important parameters for good urbanism is for buildings to give positive definition to the shape and function of outdoor space. This can be applied to and becomes achievable when;

o Urban intensification takes place and built form increases.

o Outdoor spaces should be designed to encourage a range of activities to take place.

o Improvement to the usability and quality of the green space.

\section{SITE COMPOSITION; APPLYING STRATEGIES OF BUILT FORM TO SLOPED TOPOGRAPHY}

Keywords: topography, built form, landscape, geographic identity, urban identity

Explicit qualities dealt with when composing a site becomes the relationship between the built form and topography of the land. In general sense Enis Aldallal describes the employment of topography in architecture and urbanism as a distinguishing characteristic of the land, one which possesses the ingredients to determine an architectural plan, the organisation of paths, flow of utilities, use of areas, disposition of buildings whereby the resulting visual form is dependant upon it. (57) Through this intellectual and physical engagment, both built form and landscape can become signifcantly transformed and adapted. Dwellings should complement the site's natural conditions and it is important to examine site in the early stages to fully understand its potential.

Richard Neutra considers a city as an 'evolving to- 
pography' in which the landscape is consolidated over time from successive layers of intersecting built and ecological form. Other theories are made by Enis Aldallal which relates topography to the wider consideration of a city and the reflection of an inherent geographic identity being established. "Identifiable topography is not only that which links architecture to nature but also to the city," which helps to make understanding of topography becoming related to the wider urban identity of a city and not just at a local scale. Lynch stresses that designers should be encouraged to look at the ground in ways that enable them to establish connections with an integrated framework of relation to place and that designing with urban topography is more heavily contingent on one's ability to direct and shape design ideas at both small and large scales. (Lynch, Kevin. 62)

Accompanying views of linking topography to built form, city form and place there are also general strategies which can be applied by designers when dealing with sloped conditions to conduct a more sensitive approach to dealing with inherent landforms. Friedman recommends for existing vegetated areas, clusters of homes should be constructed in natural clearings to avoid disrupting local flora and fauna while running parallel to contour lines which reduces sharp changes in elevation. He also elaborates on urban infrastructure related to residential settings, mentioning how similar to built forms, the siting of paths and roads can be adjusted to follow a site's natural contours. "On sloped sites, paths can be constructed on exisiting flat areas rather than on new ones," so as to minimise the amount of land that is disturbed during construction. From this, dwellings can be designed perpendicular to them since they provide opportunites to build stepped or split level typologies. (Friedman, Avi. 25)

\section{NATURAL ECOLOGIES IN AN URBAN ENVIRONMENT}

\author{
Keywords: natural environment, human senses, human \\ activity, desire for interaction, biophilic design
}

As most people on the planet live in towns and cities, the majority of daily interactions with nature take place in urban environments which prompted a recent interest in this field and the dynamics between these new found relationships. (Bradshaw \& Bekoff) Urban dwellers seek out interactions with nature in many forms by engaging in activities such as visits to public green spaces, maintaining private gardens or watching wildlife. These are all examples in which human activity becomes an integral part of the natural environment and a relationship to be considered important for a quality urban enviroment. "Going outside is actually a more normal, ordinary activity in a dense city because there it's an indivisble element of daily life." (Opher, Philip)

Visiting urban green space can be no more than indirect exposure to natural vegetation while engaging with other leisurely activites such as sports or walking. Whereas, more intimate interactions may involve sitting and relaxing under a canopy of trees or more actively engaging with nature by bird watching or occasional community gardening. Peter Schantz's studies agree with this and he notes how the integration of biophilic design in urban settings help to draw people outside and propel humans to live more physically active lives. His studies conducted in Stockholm demonstrates a correlation between urban green space contributing to one's decisions to partake in urban environment activities - activities which are important for leading more physically and socially active lives. (Beatley, Timothy)

Irvine and Warber leads on to say that visual appreciation and vibrancy of quality natural environments is a strong trigger which prompts the desire for interaction through the human sense. 
By nature we as humans have a desire and appreciation for environments which our bodily senses can respond and engage with. "A brightly coloured bird to the smell of fragrant flowers, the taste of berries, the sound of a birdsong, wind in the trees or intermittent silence," are emotive interactions which engage with our senses.

Summary; The importance of reading about these situations and engagements is understanding that whatever form of interaction takes place, access to urban green spaces are important for the quality of life for urban dwellers, given that it leads to benefits in physical and psychological health, urban regeneration, social cohesion, sense of community and environmental awareness. (Bird, Clinton) The quality of these interactions is crucial and depends on both the proximity of green space to potential users and level of recreational value.

\section{PUBLIC LIFE BETWEEN BUILT FORM}

Keywords: public life, transition rones, gentle transitions, territories, sense of belonging

When considering built form within an urban fabric the design is not solely limited to the communication of form and space. The environment architects and urban planners create have the responsibilty to function at deeper territorial levels of engagement associated with a concept referred to in this review as public life. Unlike more fortitude understandings of form and space, public life is a more emphemeral consideration. It is a concept constantly changing over time and can vary depending on culture, gender and age. As a designer it can become difficult to incorporate this concept into architectural and urban design. (B. Savrre)

Public life in a broad sense can be contextualised as human engagement taking place between buildings. Streets, alleys, squares, balconies, buildings, small or large, are all components considered to be part of the built environment in which public life unfolds. Jan Gehl's Public Space and Public Life has been cited to learn about how built form and urban fabric can combine to foster an improved public realm. By creating a hierarchical system whereby the relationship of these spaces is linked to various social groups, designers can help define the public and private realm to order the challenging concept of public life.

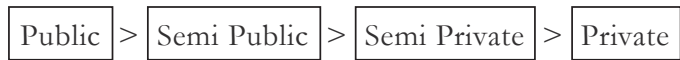

Establishment of clearly defined social and physical structure has been proven to create transitions between the various categories of public spaces labelled above. Jan Gehl refers to Ralph Erskine's housing project in Landskrona as a project with a well considered social and physical structure which makes gentle links between city street and residential groups to promote a sense of belonging. The designers' goals were to inhibit and promote quality human interaction at different public and private levels while ensuring a spatial interplay between spaces is not over designed to create a sense of demarcation from the outside world.

Jan Gehl emphasises that it is particulary important for residential areas to establish gentle graduation of outdoor transitional zones with mediation of intimate, semipublic and semi private areas near the residence to extenuate the experience of outdoor space belonging to the residential realm. As public spaces become more integrated with the residential habitat, benefits at an urban scale mean it becomes easier to meet and interact with people while providing more defined spaces which link comprehensively as a hierarchical system. The focus on increasing the value of the common spaces is intended to the create a better pedestrian experience with increased socialization and participation within the street. 
REFLECTION

There is a remarkable amount of nature in and around cities and in addition to creating more environmentally friendly urban areas it can and should begin to serve as the foundation for deeper and more meaningful quality of living. There are opportunities for urban dwellers to live in closer connection with nature and with each other.

The aim for the subsequent design research is a greatly enriched and urbanized suburban public domain. The projected increase for residential development provokes the need for social sustainability and an opportunity for ecologically sustainable growth patterns, while the desired street conditions stimulate the need to address 'placemaking' in the public realm.

The establishment of a successful gradient between the public and private realms within will be employed to help transform the suburban street into a suburban public place and consequently, improve the perception of community and willingness for residents to live together within a denser environment.

\section{DESIGN PRINCIPLES}

A. Urban consolidation and organization of space; one of the most important parameters for good urban design is that buildings provide positive definition to the shape and function of outdoor space.

B. Relationships between built form, topography and street network; how these components and can be established from combining landscape types, public space and built form as a hybrid.

C. Interactions between people and nature; ensuring vibrancy and quality of natural environments to act as a strong trigger which prompts the desire for interaction, usability of spaces and physical and mental wellbeing.

D. An objective for the design and research is to facilitate a successful interaction between public and private to enhance the perception of community and ensuring quality public realm is retained and not sacrificed from the result of urban densification.

\section{MOVING FORWARD}

The following section of work explores precedents which aim to address design principles acknowledged in the literature review to advance and develop the knowledge of this thesis. 


\section{P R E C E D E N T R E V I E W}

This chapter provides a precedent overview of urban design principles and theories discussed in the previous literature review. Precedents of urbanism and housing are selected to discover successful public realms; ones that achieve livability especially in denser housing environments.

From this overview it is possible to identify design principles in the form of architectural devices and components to guide the subsequent design explorations.
o developing urban consolidation
o relationship between built form and topography
o mediating interface between the public and private realms
o provide an integrated natural ecology network 


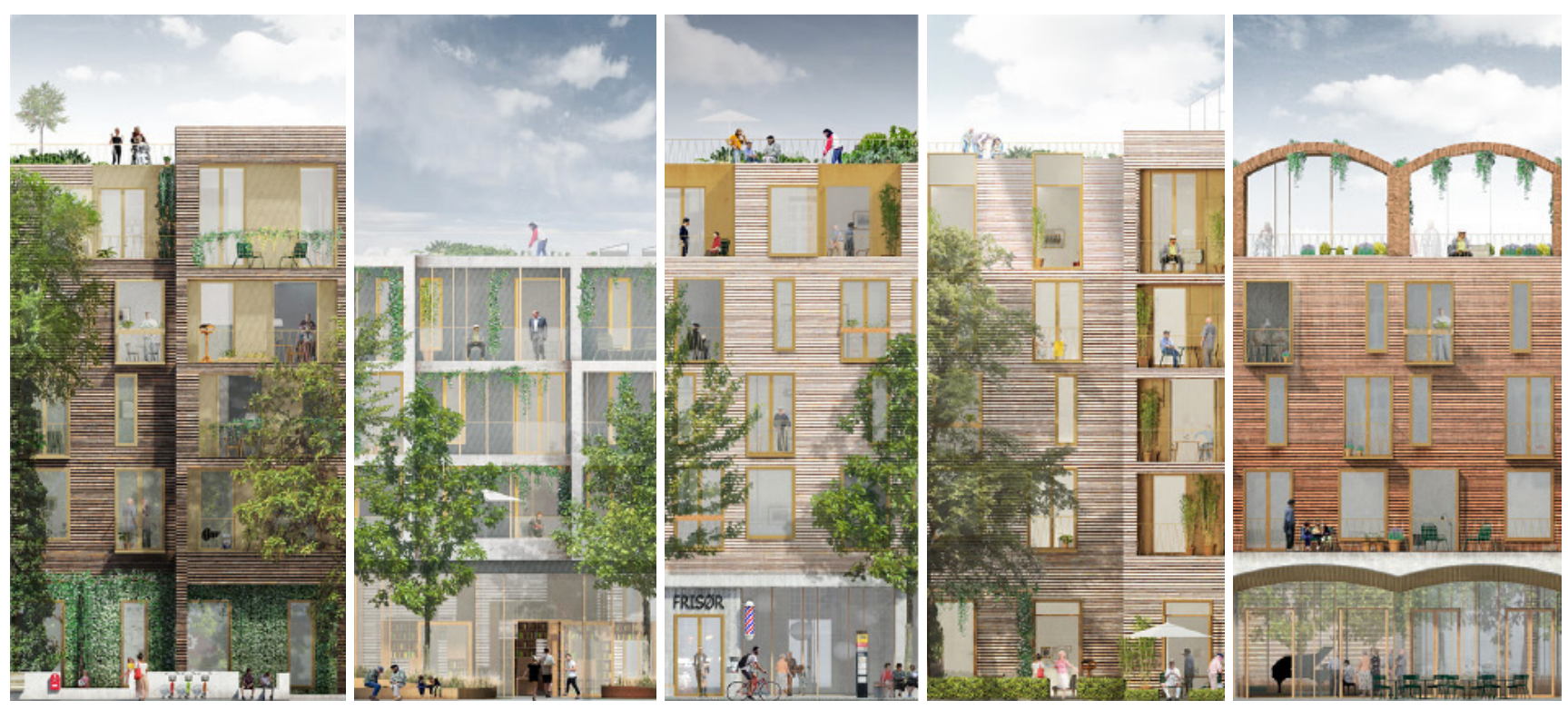




\section{N ØRREBRO, S ØLUND HOMES}

\author{
Client: \\ Architecture \& Landscape: \\ Engineers: \\ Collaborators:
}

\author{
Samvirkende Boligselskeaber/ KAB \\ C.F. Moller in collaboration with Tredje Natur \\ Bascon, Transsolar \\ Smith Innovation
}

\section{PROJECT ANALYSIS}

Located in Copenhagen's Nørrebro district, the Sølund care homes is a 360 dwelling urban housing project set to function as an urban activity generator to provide the area with life and atmosphere with its many residents, staff, and guests bringing life and atmosphere into the district. The mix of housing types, residents and visitors is unique in a Danish context, and it will become a central anchor point for the development of the entire Nørrebro district. The design gives residents an opportunity to interact with people of other generations while simultaneously setting higher standards for well-being, security, functionality, and community values.

This precedent will be analyzed for findings in;
A. Urban Consolidation \& Density
B. Relations between built form and natural ecology network
C. Public and Private Relation 

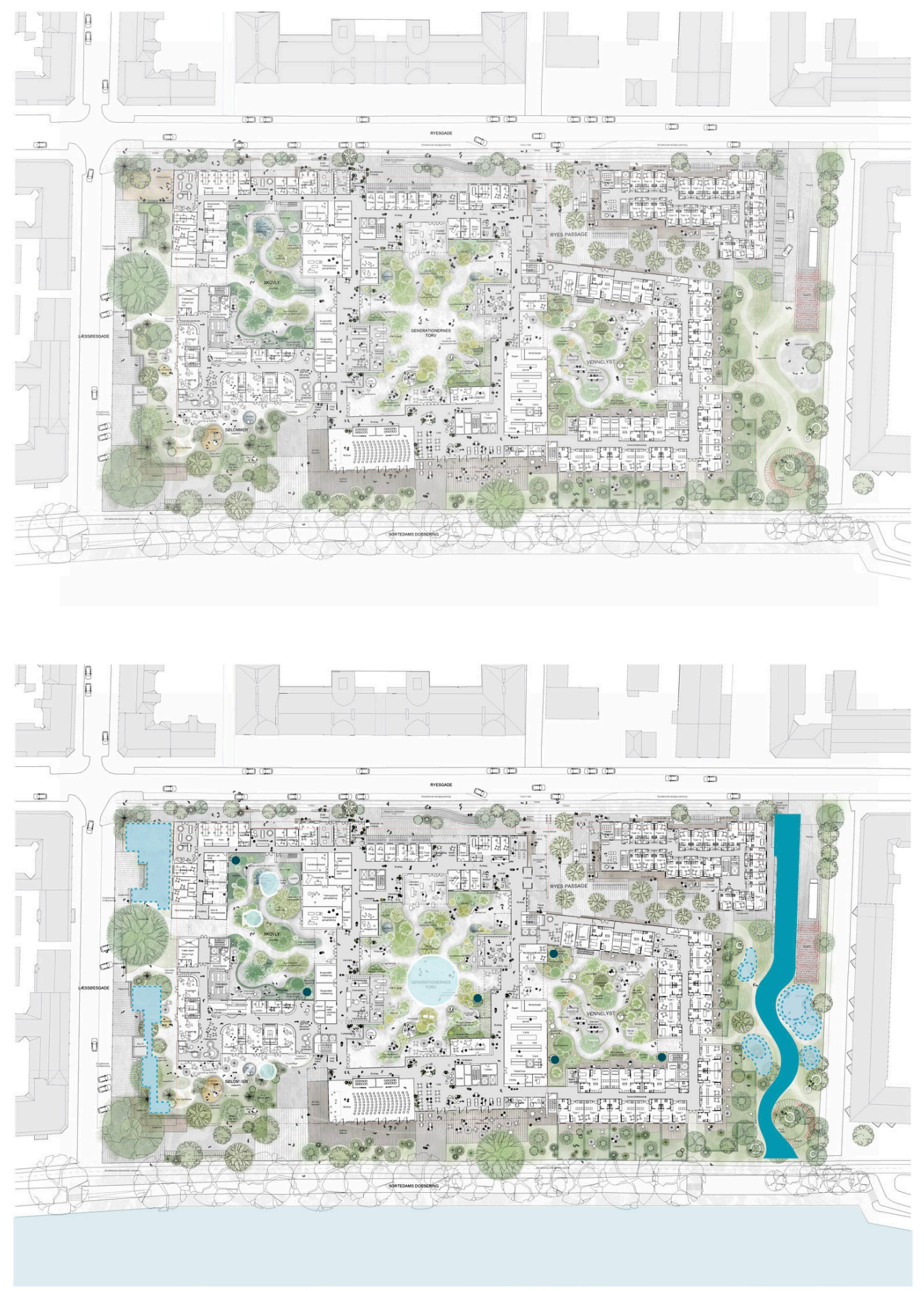

Figure 5 // Norrebro Solund Homes; site plan with ecologies labelled 

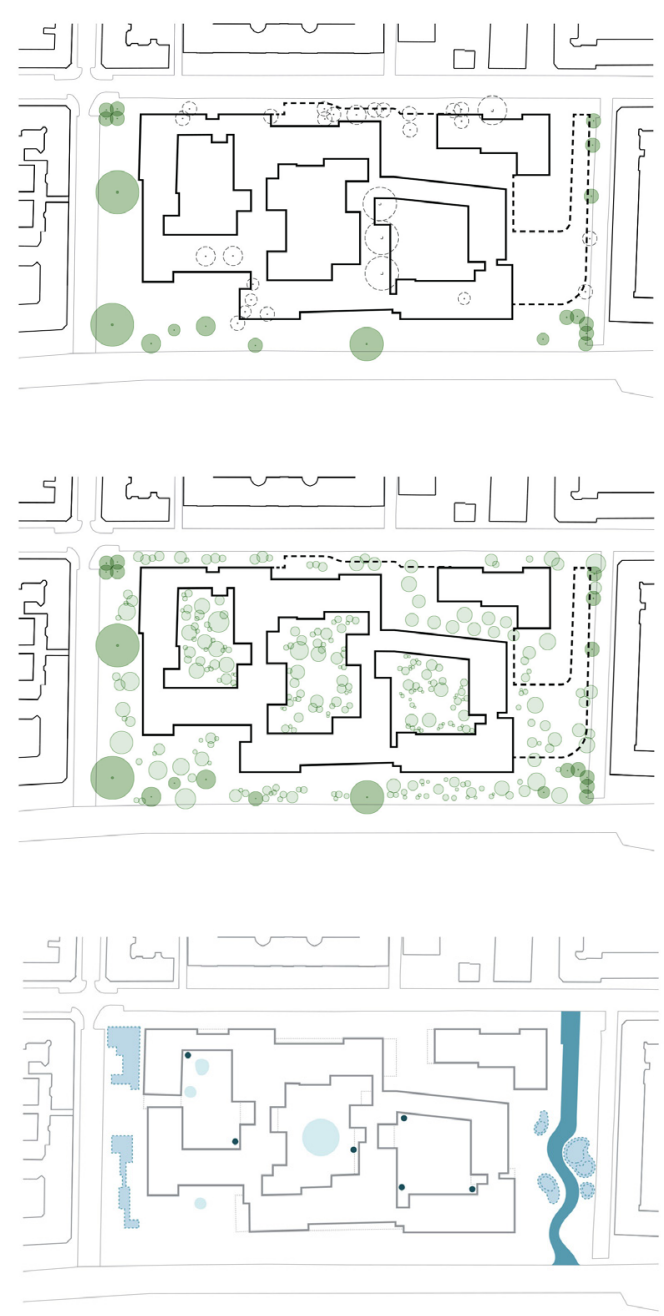

\section{$\wedge$}

Figure 6 // Norrebro Solund Homes; hydrology and vegetation ecology
The architects are looking to re-emphasize the structure of the classic Danish city block's common areas. The central Generation's Square is a semi-public urban space, and connects to the two other more private courtyards. It is the largest yard functioning as a common space for everyone. A place which is a reflection of diversity as residents, youthful or elderly can meet. The Square appears as a green opening combining the housing blocks into a single and harmonious entity.

Major trees along the street have been retained and benefit the design by providing cooling shade for pedestrians and for the housing blocks. Smaller trees and shrub species with branches lower to the ground have been planted in closer proximity in and around the housing blocks.

The complex enhances the surroundings with an attractive, permeable green edge. The variations in landscape zones that face the city are completely public and can be used by the city. In addition to the extra planting around the building, natural ecology features such as storm water handling and sustainable urban drainage are fully integrated in the landscape design.

\section{LEARNINGS + PRINCIPLES}

A. Urban consolidation and resulting built form must be able to respond positively to a street edge. A building might respond to multiple street conditions so it is important that each response is considered whether it be confronting, stepping back or providing an interstitial space from the street.

B. Develop transitions between private and communal/public space to structure social interactions and enhance gradients of privacy. 
Dwellings are located above street level with smaller, privatized balconies

Recesses in street façade to break up otherwise linear block edge

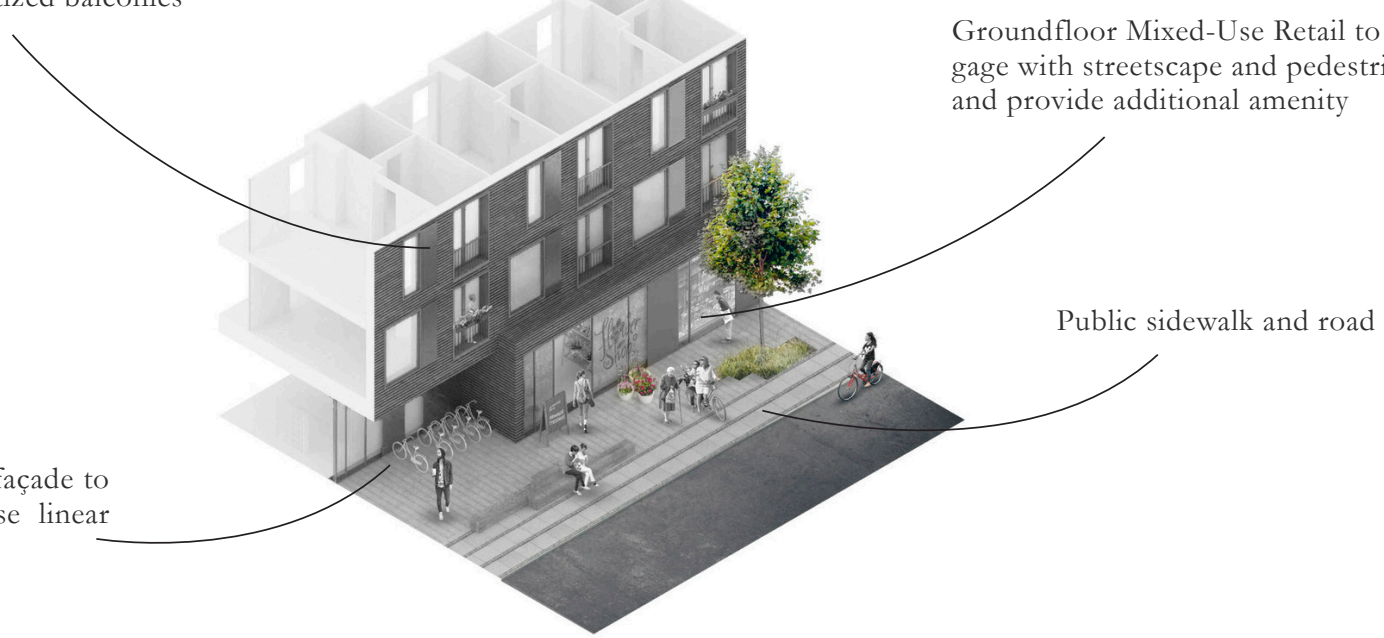

The narrow street edge consisting of a public sidewalk and road means this edge of the housing block becomes more privatized and closed off when compared to other street scenarios. Mixed-Use retail is located at the ground floor to retain relationship to the street.

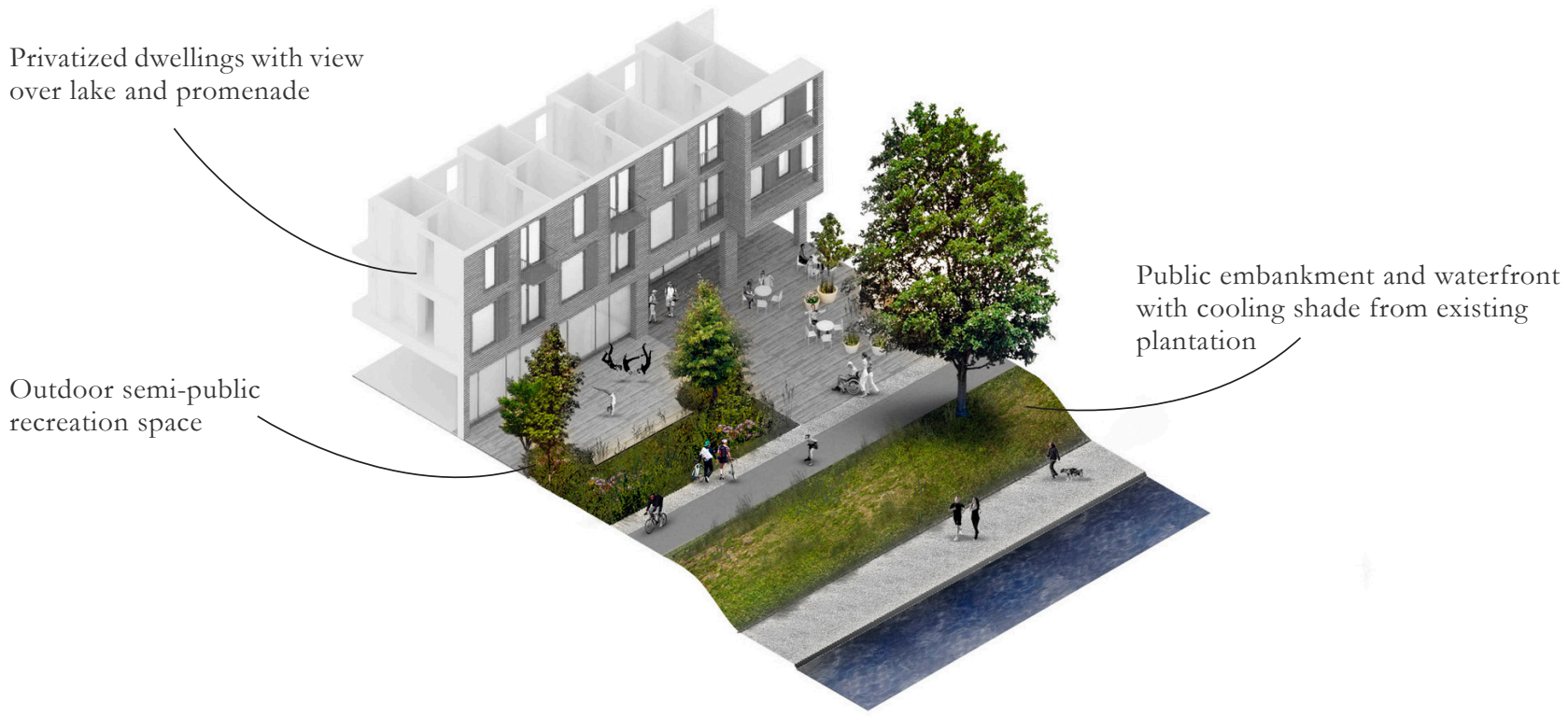

A ground floor, multi-functional venue faces the lake that is densely populated by pedestrians. The block is set back from this edge to provide semi-public recreational space and outdoor café seating. An embankment, additional plantation and shrubs assist in providing privacy to residents, from the street. 


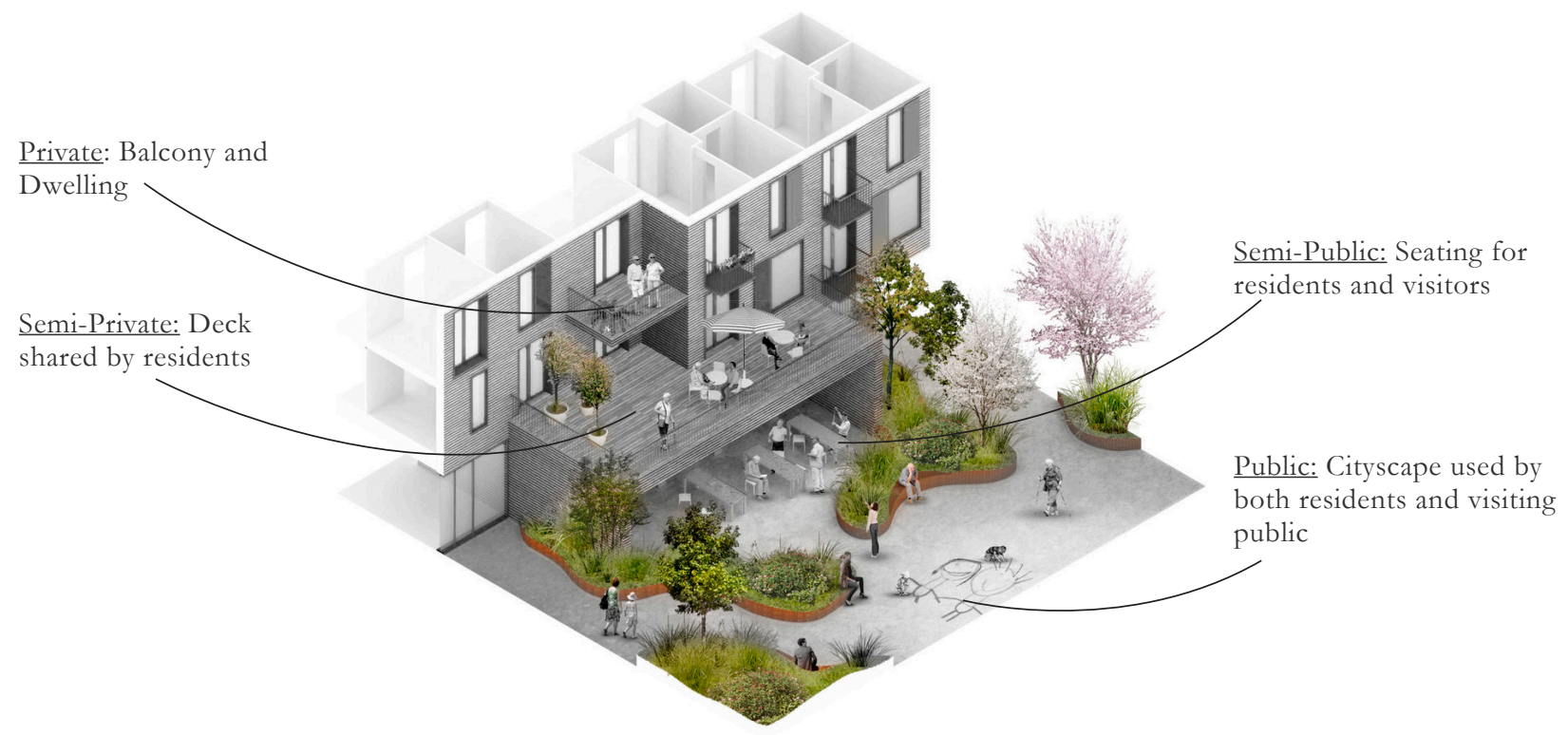

The Sølund Housing Block creates its own green cityscape inviting children, young people and seniors to be involved in shared activities and to partake in the urban life that has been created. This scenario in the design has been noted for having a clear structure of a public to private arrangement with a consistent scale progression at each shift.

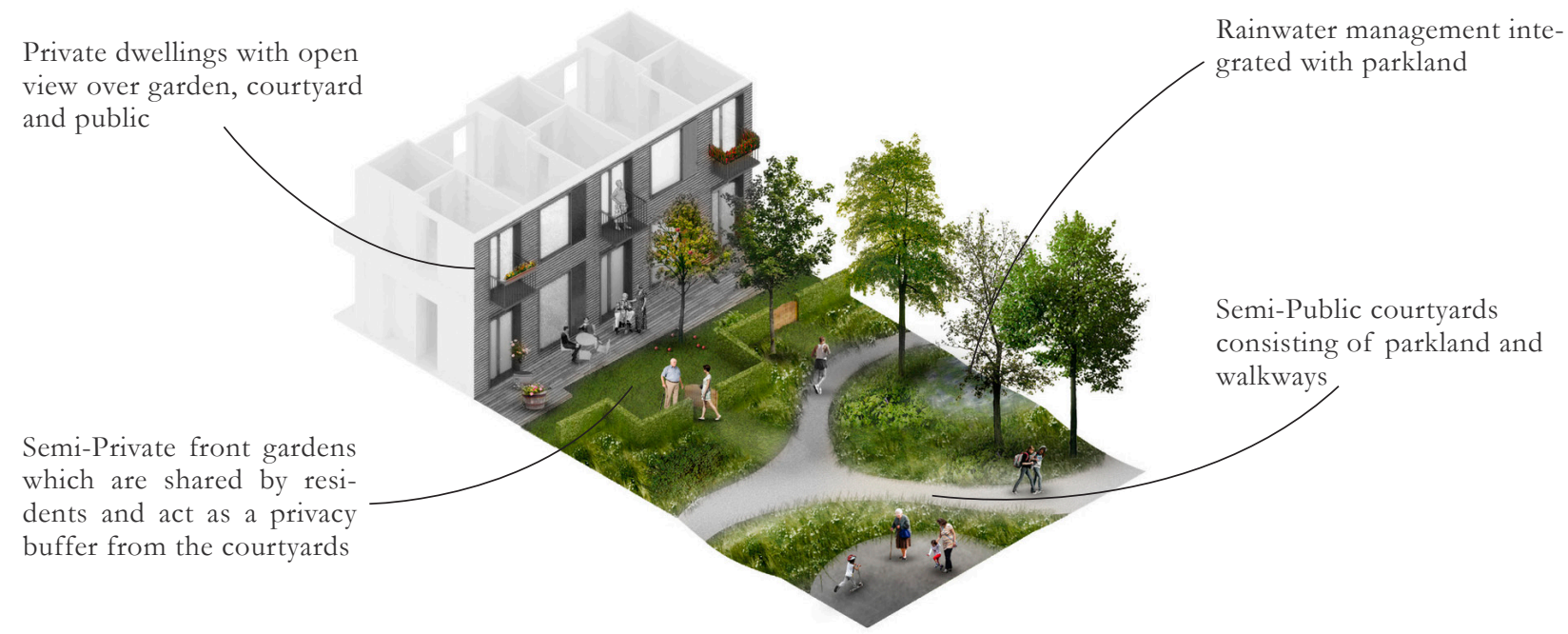

The courtyards are a more open, semi-public urban space consisting of recreational areas and walkways for residents and visitors. Located between the courtyard and the housing block is a semi-private front garden which is used to provide adequate privacy for their dwellings. 


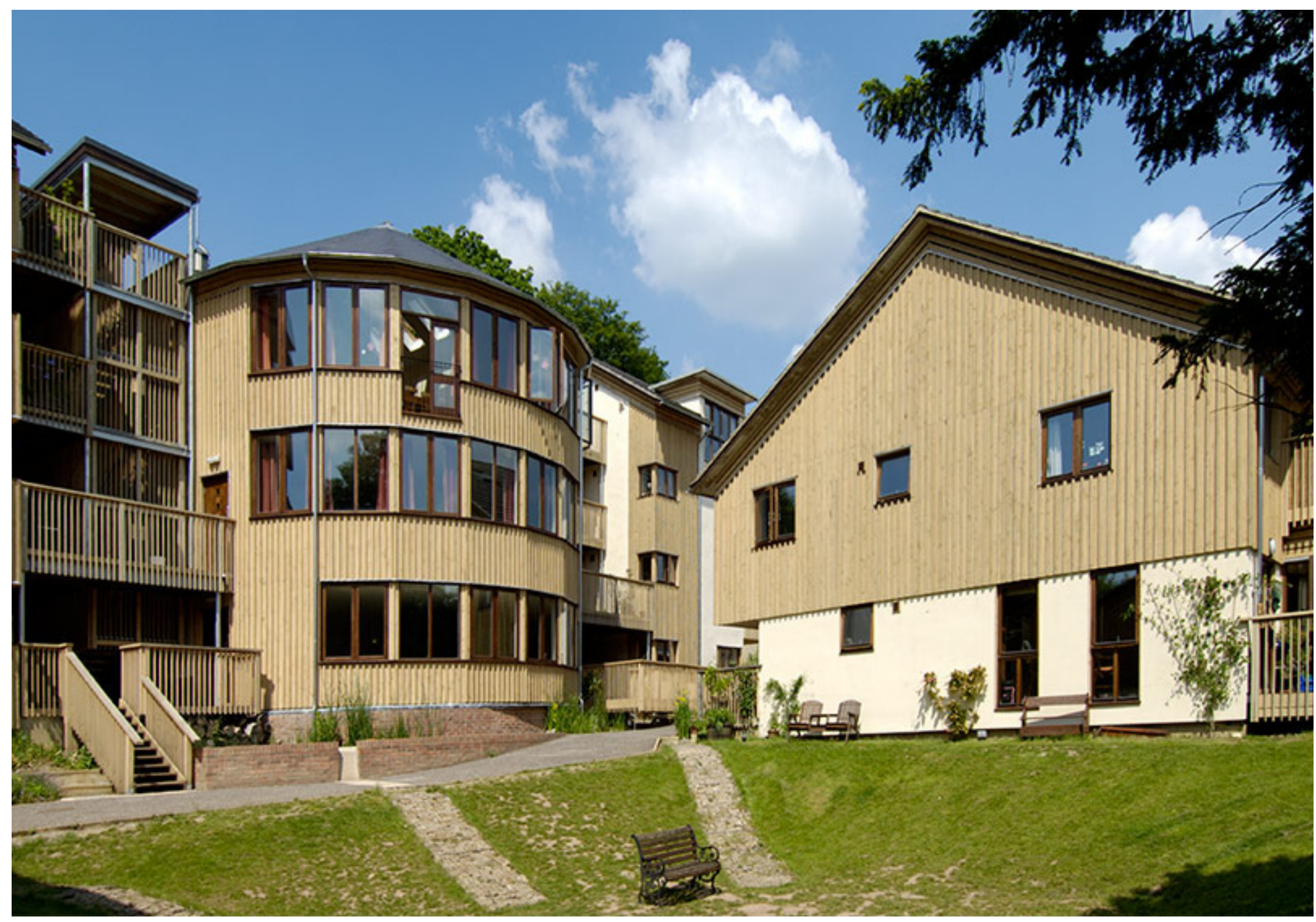




\section{S TR OUD, S PR INGHILL C O-HOUSING}

Client:

Architecture:

Landscape:

Location
David Michael, director of Co-housing Company Ltd

ARCHITYPE

Robert Bray Associates

Stroud, Gloucestershire

\section{PROJECT ANALYSIS}

Springhill Co-housing is a new build co-housing scheme consisting of 35 private dwellings, designed with the full participation of residents located within a suburban area of Stroud, UK. Based on the Danish model, co-housing is a form of collaborative housing that aims to create a sense of community and achieve true social and environmental sustainability. The emphasis of this precedent review is to focus and evaluate upon the integration of social and ecological housing design. The project creates social street networks between the units and links natural ecologies on the site through treatment of landforms down the slope and well considered ecological infrastructure, which enables the project to create a vibrant, strong and sustainable community.

This precedent will be analyzed for findings in;
A. Integration of natural ecology networks in housing design
B. Public and Private Relationships
C. Relationship between built form and topography 


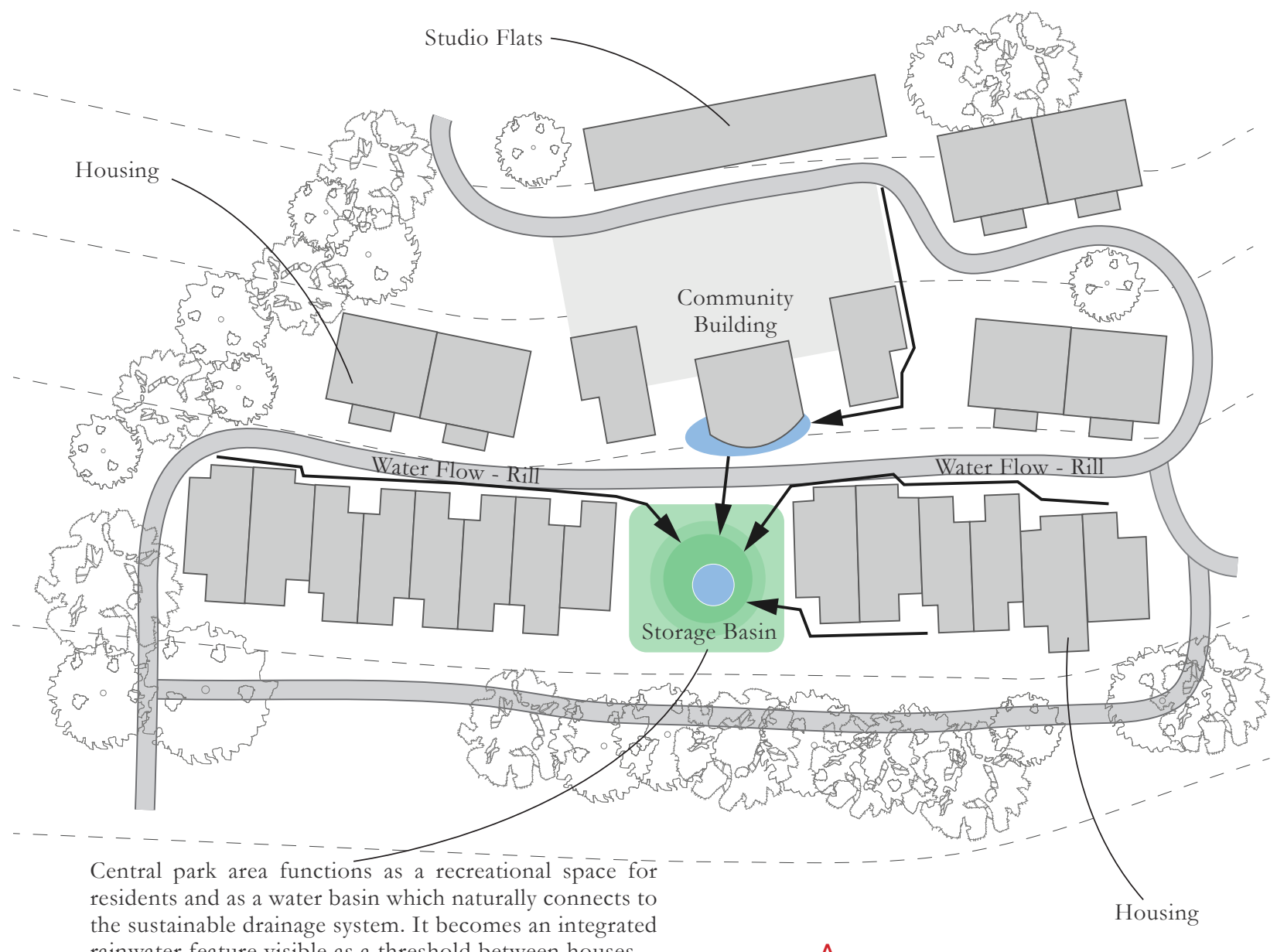

rainwater feature visible as a threshold between houses.

Figure 12 // Springhill; site plan with labelled water ecology
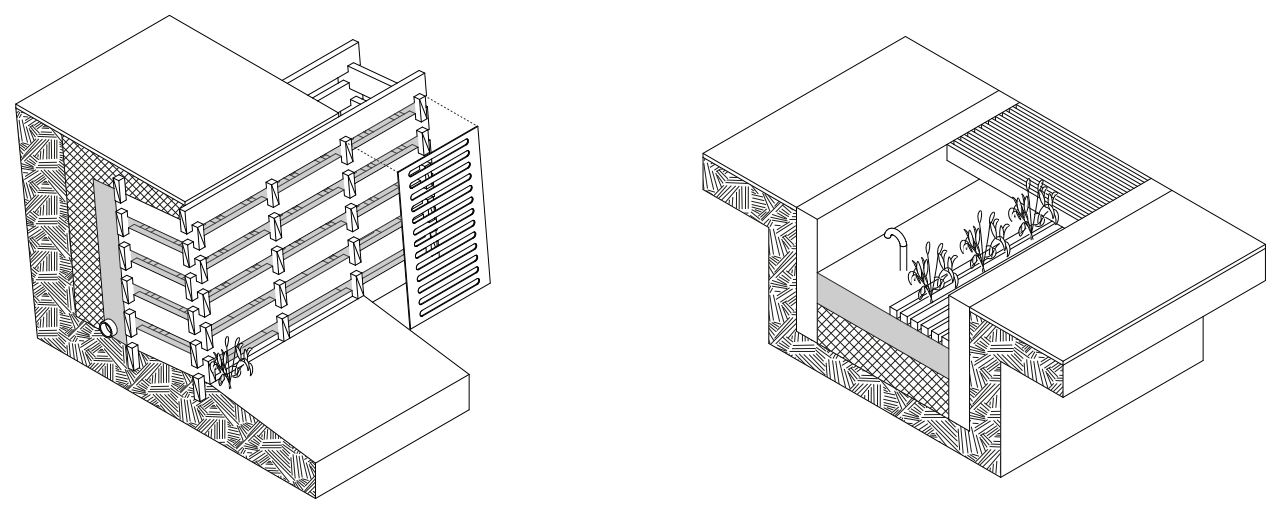

Timber and Rock retaining structure used to shape land on sloped site.

Planted rills along connecting walkways lead to a communal pond aiming to celebrate the flow of rainwater. The rills give life to vegetation which grows up to street level and also helps to clean the rainwater as it travels off the street. 


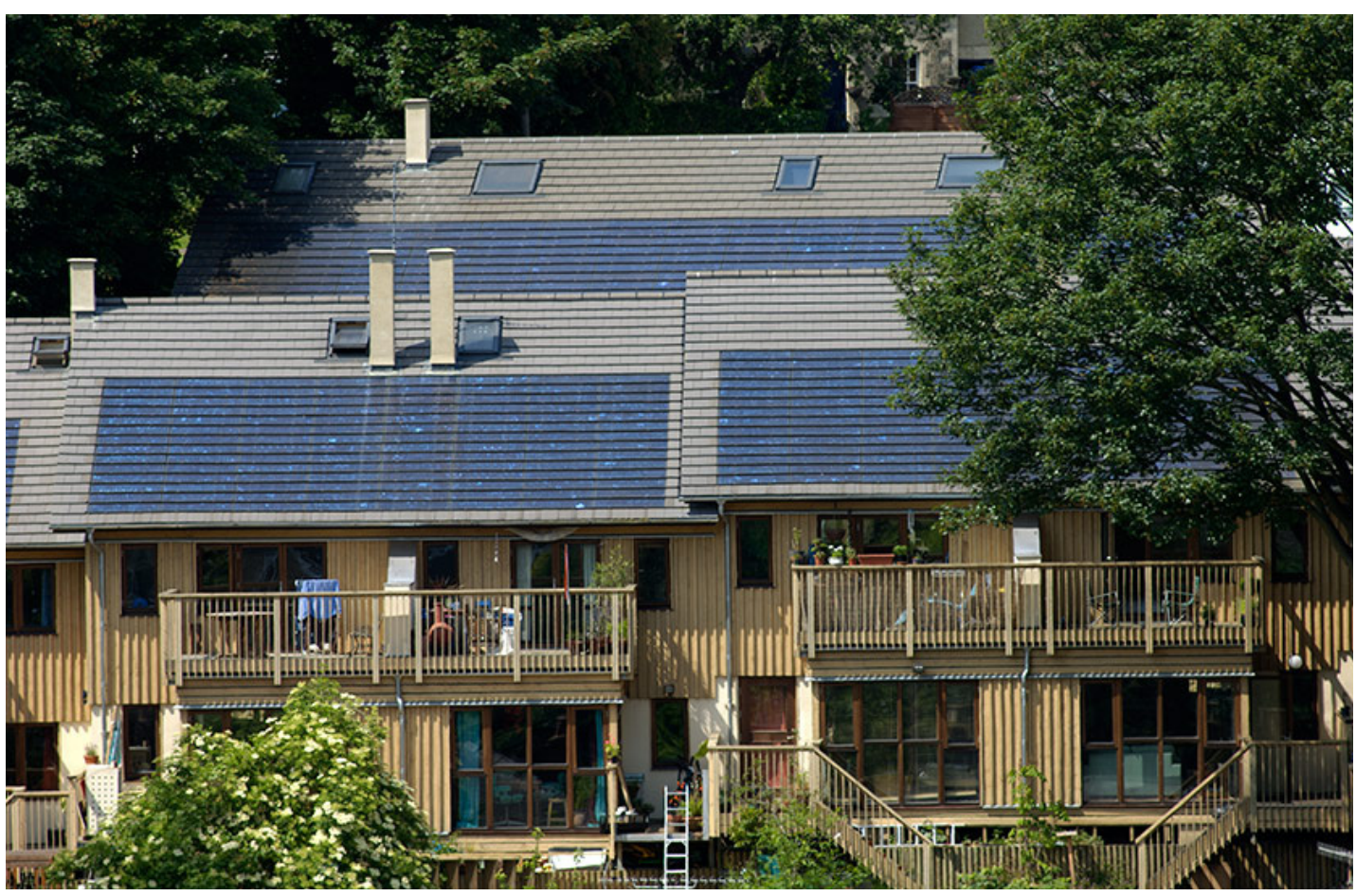

Built on a steep site in Gloucestershire provided the project with an opportunity to integrate a sustainable drainage system that would complement the 'green' credentials of the development. Robert Bray Associates was engaged organize a SuDS management network to link outdoor spaces around the housing together. Additional aims were to link people to these spaces as well. The SuDS design at Springhill aims to create this cohesion between ecologies, landscape and residents. Integrated rainwater features become thresholds between houses, thoroughfares, gardens, play areas and sub-catchments.

Planted rills with cascades along with a communal pond aim to celebrate the flow of rainwater and give the development a unique character desirable for residents.
The project has developed a new housing typology, based on the home owners' requirements and principles for collective living and neighbourliness, including:

o Pedestrian and child friendly site, with cars kept to one perimeter edge.

o Communal/shared and outdoor space, with no private gardens.

o One shared common house at the centre with facilities including work shops, playroom and kitchen.

o An organized car share scheme and bulk buying of organic food.

$\wedge$

Figure 15 // Springhill; front elevation photo 


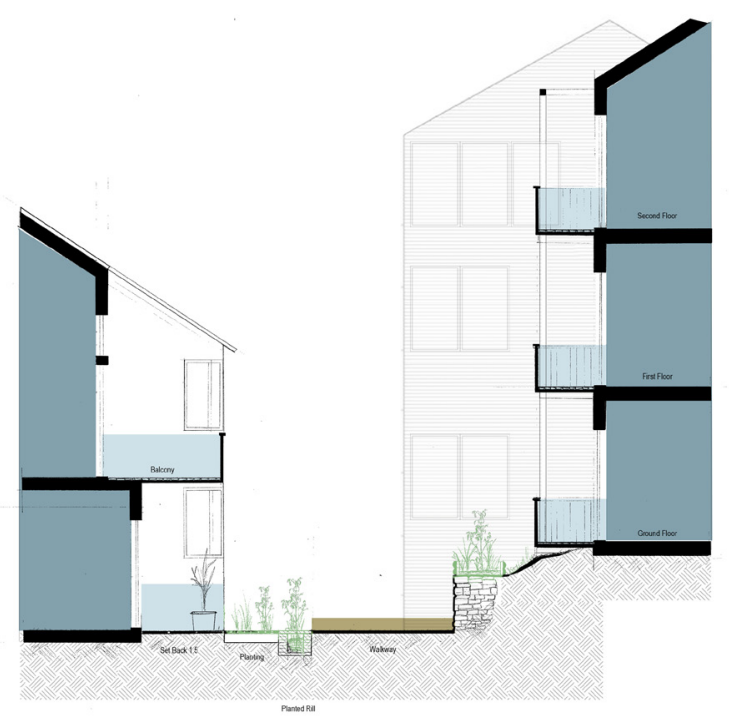

FIG. 10

Communal Street Section / Public and Private

\section{Private}

Semi Private

Semi Public

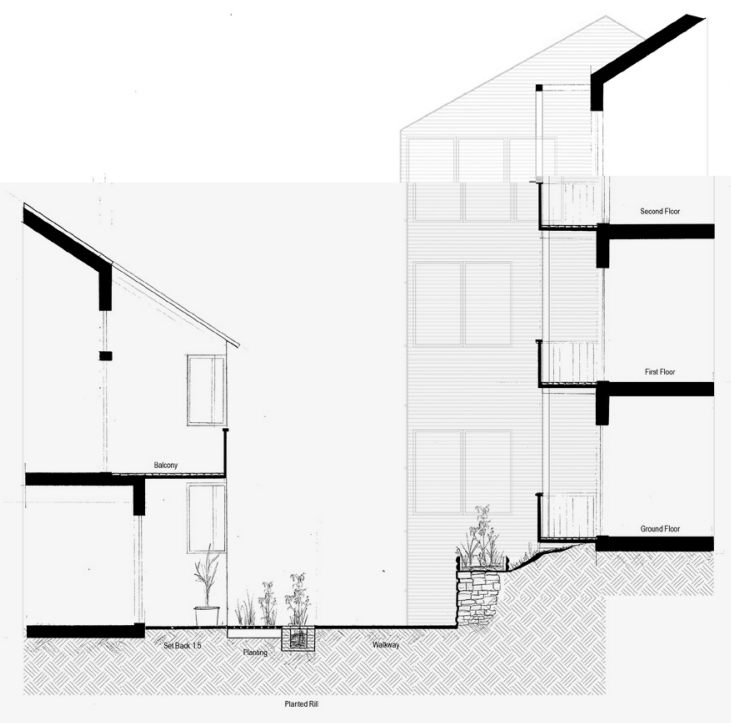

$\wedge$

Figure 16 // Springhill; public and private street section

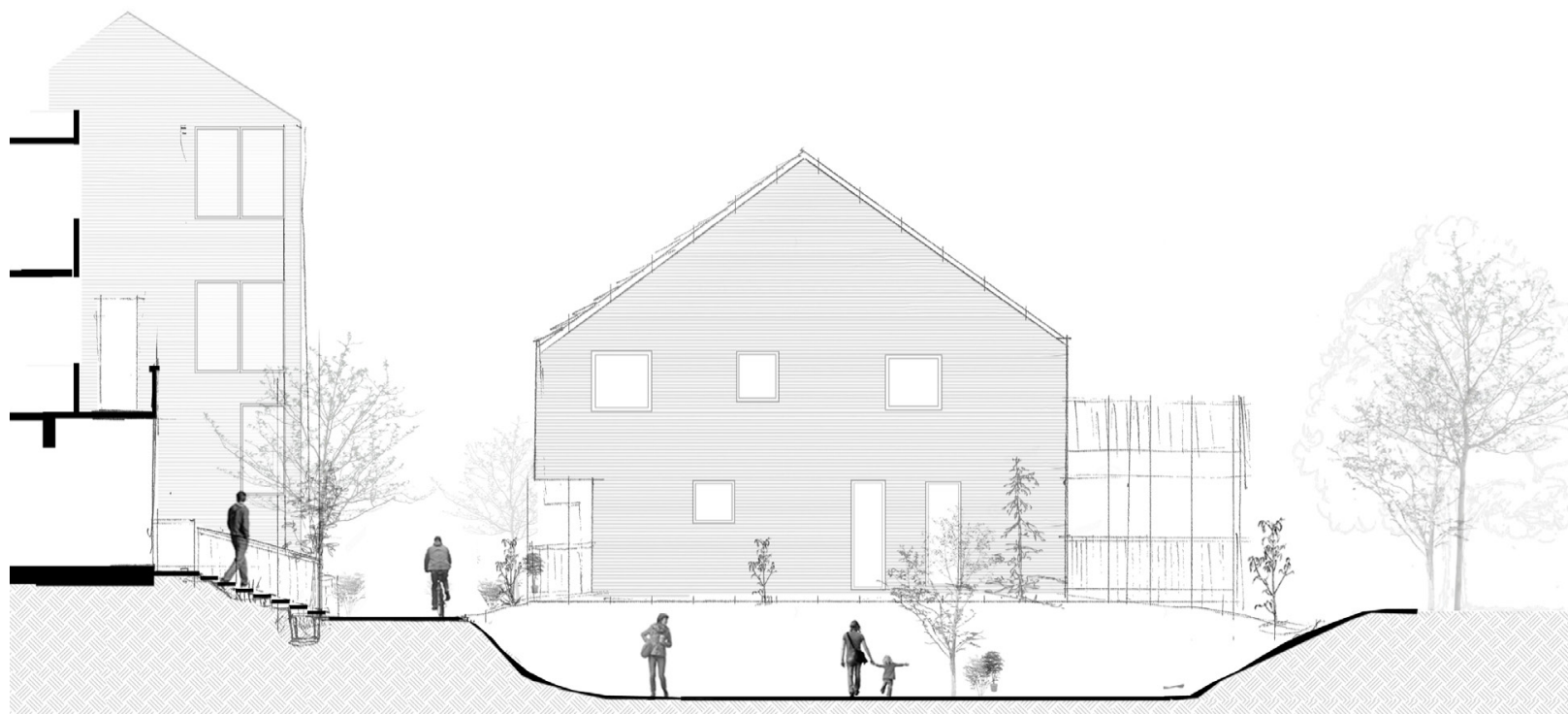

FIG. 10

Sectional Sketch through Storage Basin \& Play Space

\section{$\wedge$}

Figure 17 // Springhill; section sketch water basin and play space 


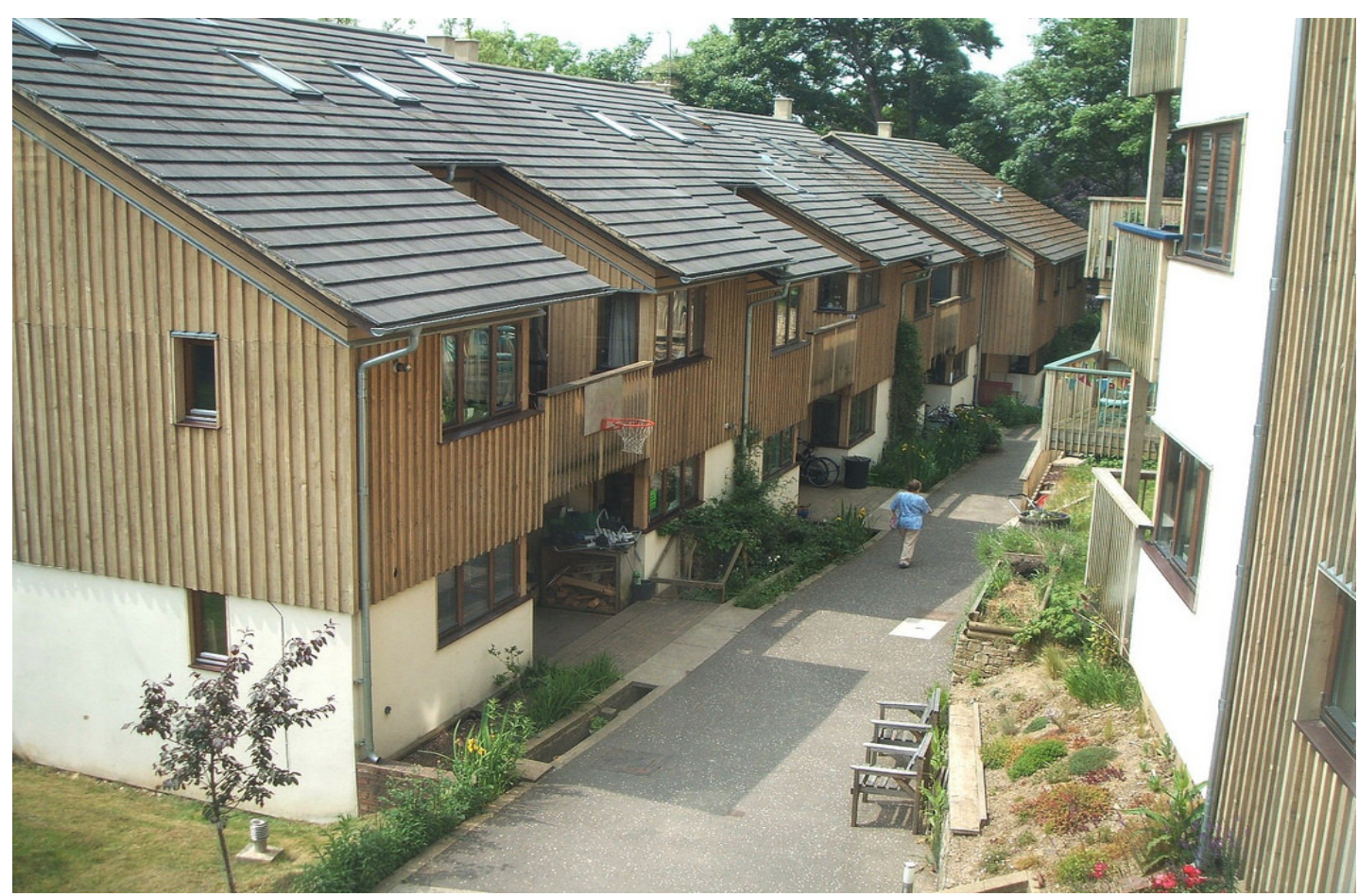

All of the dwellings share a very close proximity to the communal streets. Privacy for residents is achieved by having entrances and front doors set back from the street as a slight buffer. Balconies are also lifted up above street level on either side to inhibit privacy yet still encourage social engagement between people in the dwellings and pedestrians or children playing out on the street.

The street between the buildings becomes a driver for social interaction and interest for the residents. The urban design is successful through the use of contrasting of spaces - It narrows down between buildings but also has the uniqueness of larger contrasting spaces such as the storage basin which is linked to the path.

\section{LEARNINGS + PRINCIPLES}

A. Integrate cohesion between ecologies, landscape and built form. Where there is opportunity public spaces can be linked with existing greenery.

B. If all spaces on a particular site are designed to the same amount of enclosure, scale, proportions and detailing then result can become monotonous. When linking public spaces the urban design should look to create contrasting spaces.

\section{$\wedge$}

Figure 18 // Springhill; internal street view 

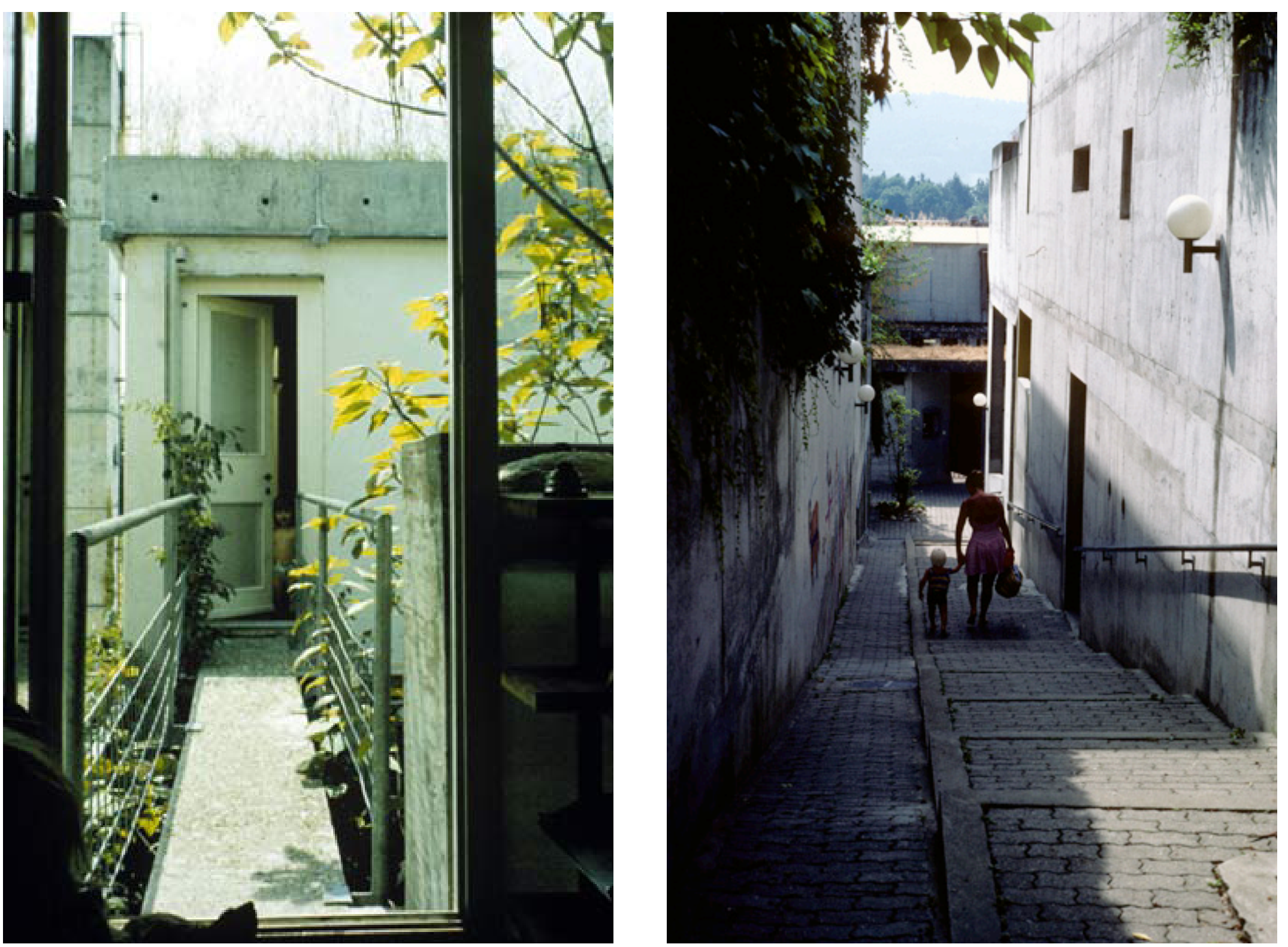


\section{BERN, SIEDLUNG HALEN}

Client:

Architecture:

Location:

Density:
David Michael, director of Co-housing Company Ltd

Atelier 5

Bern, Switzerland

81 dwellings. 110dph

\section{PROJECT ANALYSIS}

The Siedlung Halen Housing Estate is located $5 \mathrm{~km}$ outside of Bern in Switzerland and consists of 81 low rise, high density terraced houses. Designed by Atelier 5, who were influenced by the work of Le Corbusier the project focuses on combining advantages found in both suburban and urban housing. The design also incorporates modernist program of the 1920's about community and privacy, garden city notions of a healthy lifestyle in a suburban setting and attitudes about material and standardization.

Built on a hillside the terraces are reminescent of steps. The simple concept of stepping down the site means the built form creates views for the dwellings located towards the back, green balconies, walkways and intermediate space which residents can occupy.

This precedent will be analyzed for findings in;

A. Relationship between built form and topography

B. Urban Consolidation \& Density 
This precedent is influential due to its approach in establishing a high volume of built form on a sloped site. The terraced typology means it can maximize land use by stepping down the topography while still providing open green space either side of the dwellings. What this project does well is introduce the suburban idea of community into a higher density, while protecting the privacy of individuals and both the indoor and outdoor private spaces, concepts which have been developed from utopian socialist ideas.

There are designed communal and private areas throughout the site to enforce these ideals, such as communal playgrounds and private walled gardens. Like previous examples, the development is considered a success for the design not sacrificing community for individual privacy. However the aesthetic of the Siedlung Halen Housing has been criticized for appearing overly artificial and likened to more of a practical success after being designed to achieve a medium between the common and private realm.

In terms of diversifying dwellings, there are only three types of units with only minor variations in plan. The units are positioned alongside in a row rather arbitrarily to give some illusion of diversity and to provide a high yield of $110 \mathrm{dph}$. The width of each dwelling is a narrow five meters that would limit most design freedom in plan in order to follow along the ideas of standardization which was sought after as a suitable response to post-war housing. The standardized planning could be critiqued for not offering a wide range of opportunities in internal organization that might better influence the median between the common and private realm as well as aesthetic.
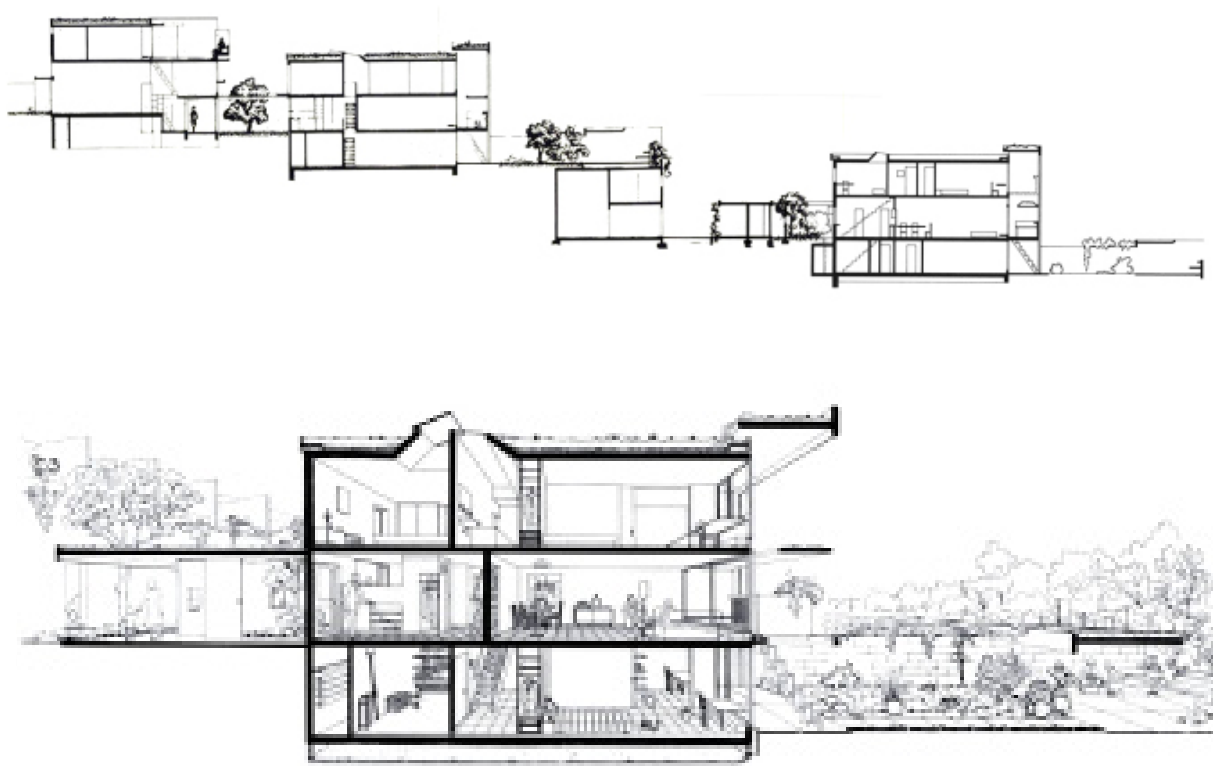

$\wedge$

Figure 21 // Siedlung Halen; long sectional drawing Figure 22 // Siedlung Halen; short sectional drawing 


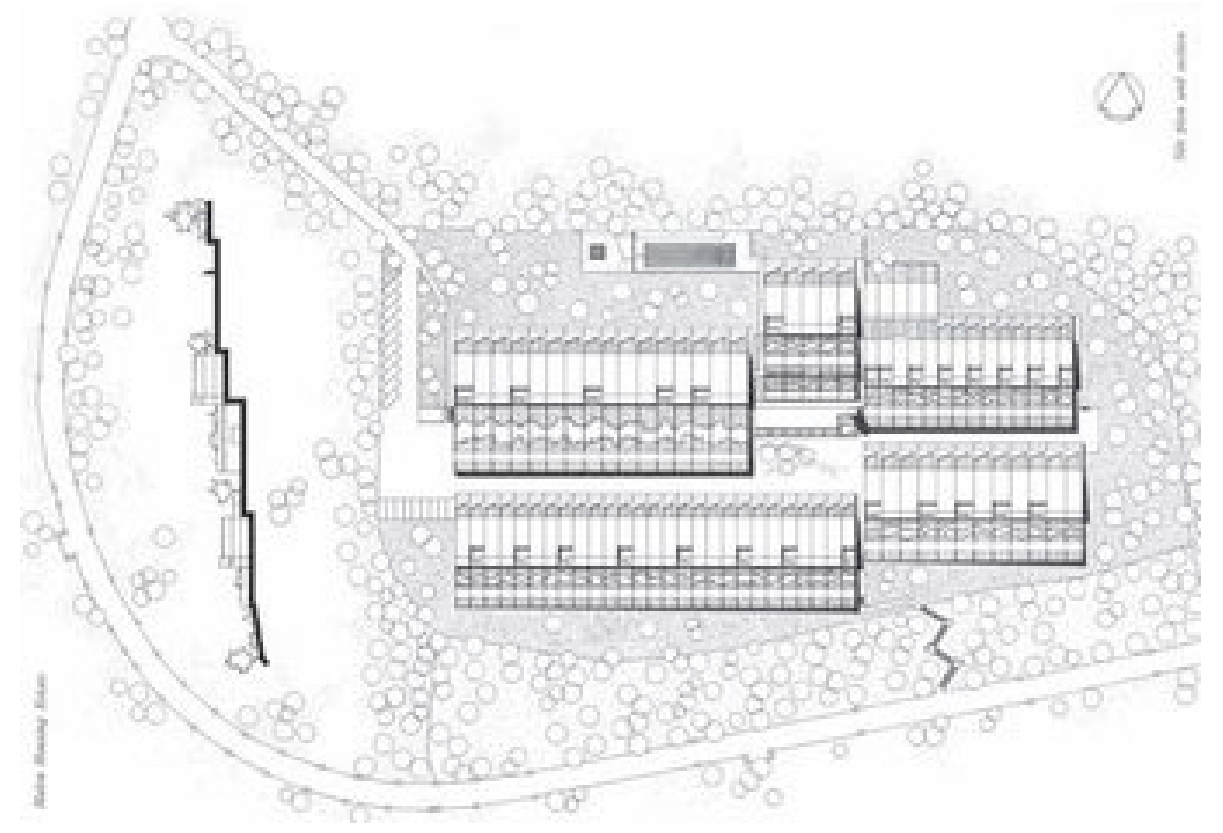

$\Lambda$

Figure 23 // Siedlung Halen; site plan

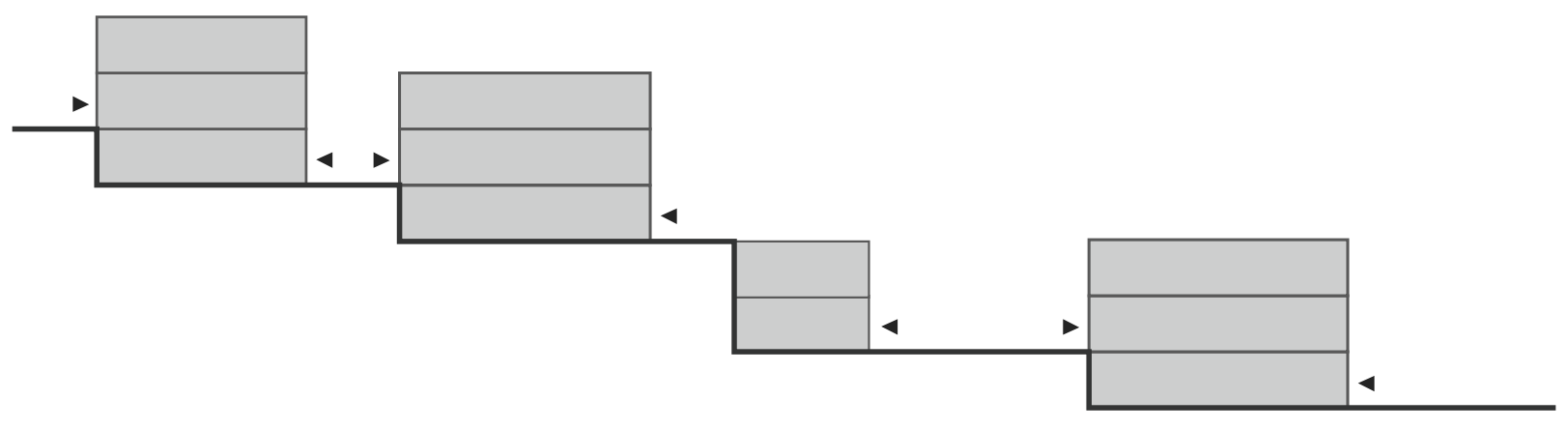

$\wedge$

Figure 24 // Siedlung Halen; concept diagram LEARNINGS + PRINCIPLES of dual access to dwelling

A. Landscape form and built form can combine to create a morphology of housing types which adjust to one another.

B. Multiple level, stepped dwellings have the abillity to become accessed from both the front or rear yards at different levels.

C. Built form and landscaping combine to create a terracing of land and terrace dwelling typology. 

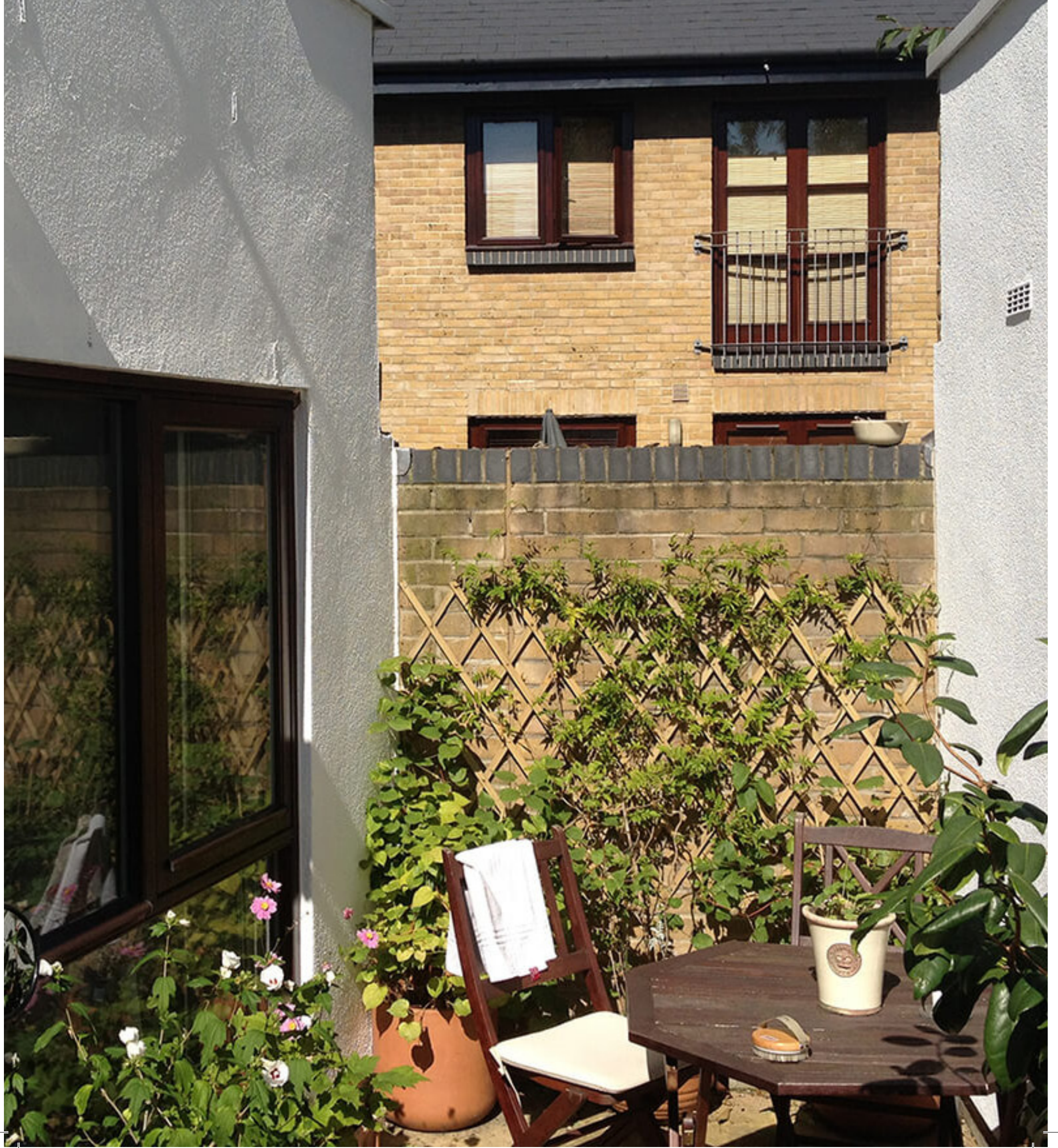


\title{
LONDON, DONNYBROOK QUARTER
}

\author{
Architecture: \\ Peter Barber Architects \\ Location \\ Eden Way, London UK \\ Date of Completion \\ 2007 \\ Density \\ 40 Dwellings at $400 \mathrm{hr} / \mathrm{h}$
}

\section{PROJECT ANALYSIS}

Donnybrook Quarter is a high-density, low-rise, mixed-use scheme designed by Peter Barber Architects. It is sited on a corner site in the East End of London. The aim was to provide vibrant and rich public space that was constrained by a harder edge of built form. Currently 130 people inhabit the 40 housing units. At the centre of the scheme a main pedestrianized street aligns the north-south of the site creating access to the dwellings on either side. The street also offers a walkable route to adjacent streets and urban fabric.

This precedent will be analyzed for findings in;
A. Relationship between built form and urban fabric
B. Urban Consildation \& Density
C. Public and Private Relationships

$<$

Figure 25 // Donnybrook Quarter; courtyard photo 


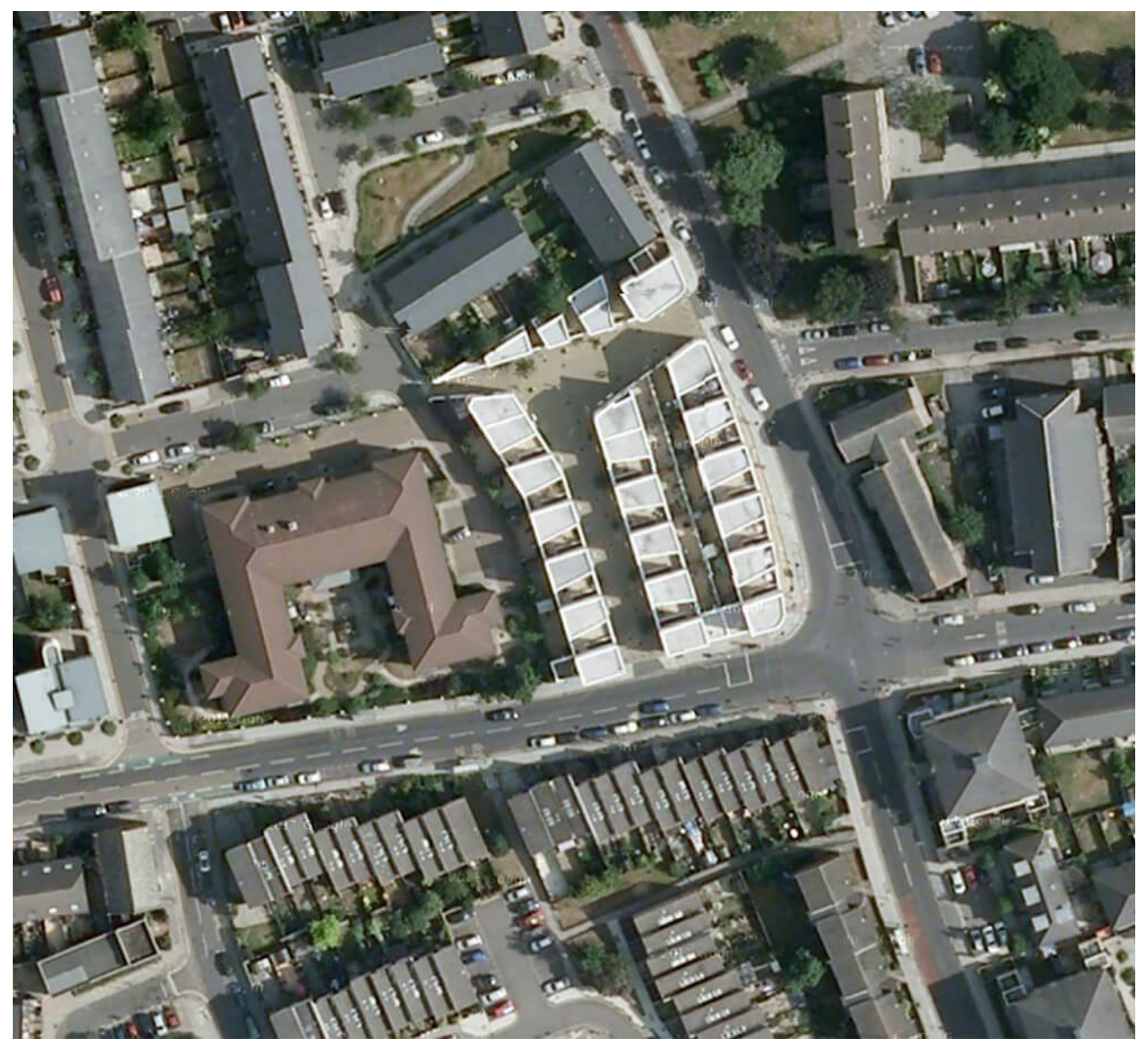

Donnybrook Site Plan

The scheme is laid out around two new tree lined streets which cross the site creating very strong spatial connections with adjacent neighborhoods.

Figure 26 // Donnybrook Quarter; site plan and street connections 


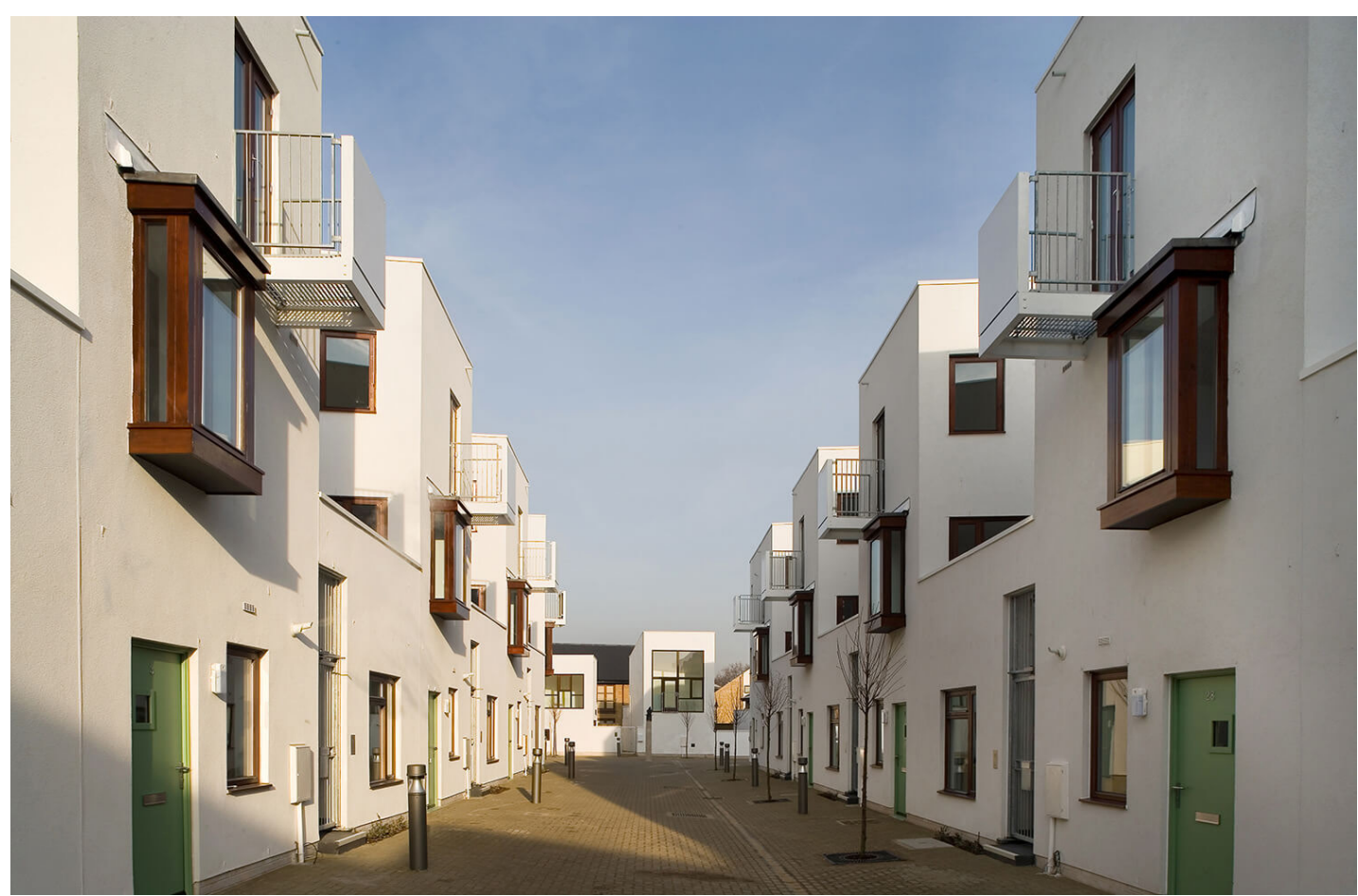

The pedestrian street is of an intimate scale, measuring only $7 \mathrm{~m}$ wide and defined on either side by two and a half storey, notched terraced dwellings. Balconies, terraces, bay windows and numerous front doors overhang and overlap the central street to create a visual intrigue and promote use of the shared space. Additional infrastructure including deckchairs, outdoor lighting and colourful planting help provide a comfortable and social place for people to pass through, congregate and meet others.

A typical double unit includes a two bedroomed masionette on both the upper ground and first floor and a two-bedroom flat at lower ground floor. The configuration as a notched terrace type enables high densities of up to 520 habitable rooms per hec- tare, while maintaining good levels of privacy and amenity to each dwelling. All individual dwellings have their own front door facing the street and their own courtyard which measure $8 \mathrm{~m} \times 4 \mathrm{~m}$. The upper maisonette is entered from the street through a courtyard garden.

In certain cases the spatial relationship between the heights of buildings and the width of the space will induce a feeling of comfort. At $7 \mathrm{~m}$ in street width and $7-8 \mathrm{~m}$ in height the space created along this street becomes psychologically restful and complete by appearing and feeling spatially enclosed. (GLC Study. 33)

\section{$\Lambda$}

Figure 27 // Donnybrook Quarter; communal $7 \mathrm{~m}$ wide street 


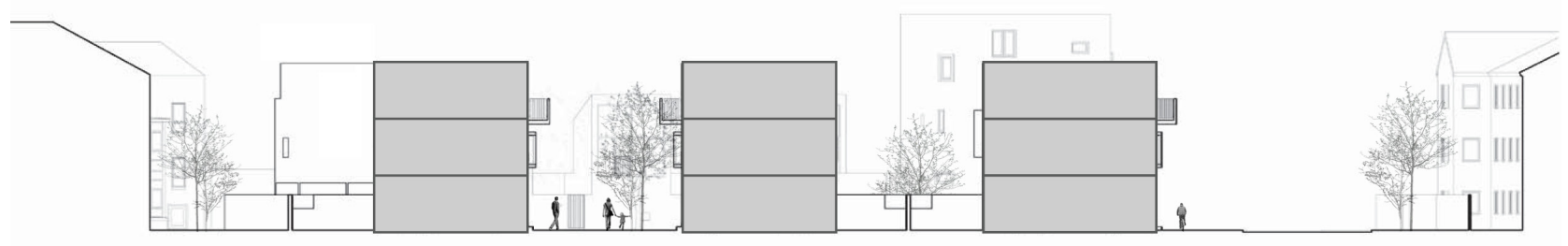

FIG. 10

Sectional view through Donnybrook Quarter highlighting street width to building height proportion of roughly (1:1)

\section{$\Lambda$}

Figure 28 // Donnybrook Quarter; street width to building height proportion

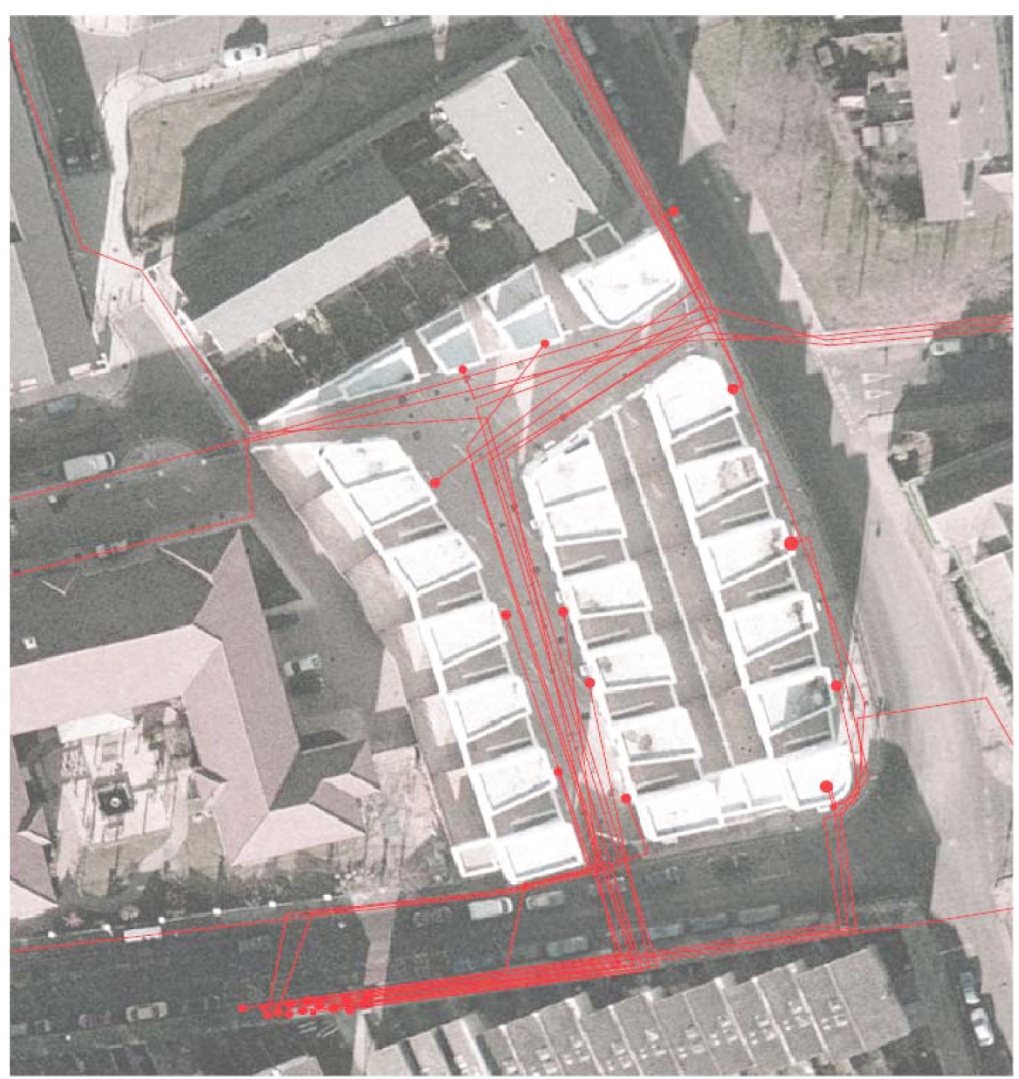

8.00-8.15am
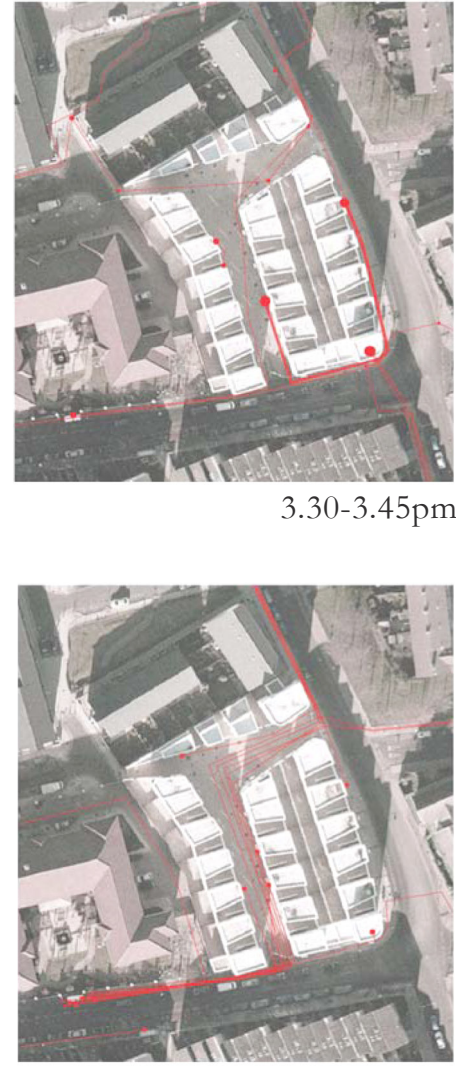

$6.45-7.00 \mathrm{pm}$

FIG. 10

Pedestrian Movement Patterns $11^{\text {th }}$ OCTOBER 07

$\Lambda$

Figure 29 // Donnybrook Quarter; pedestrian movement patterns 


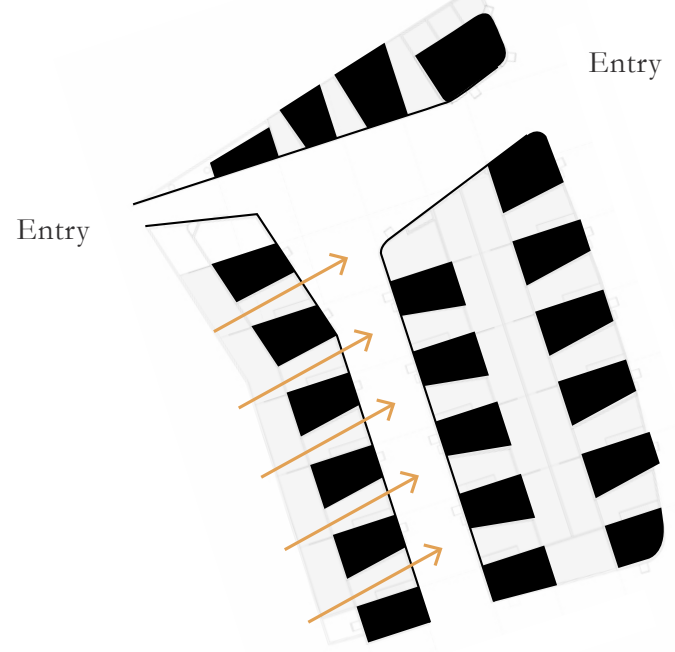

Entry

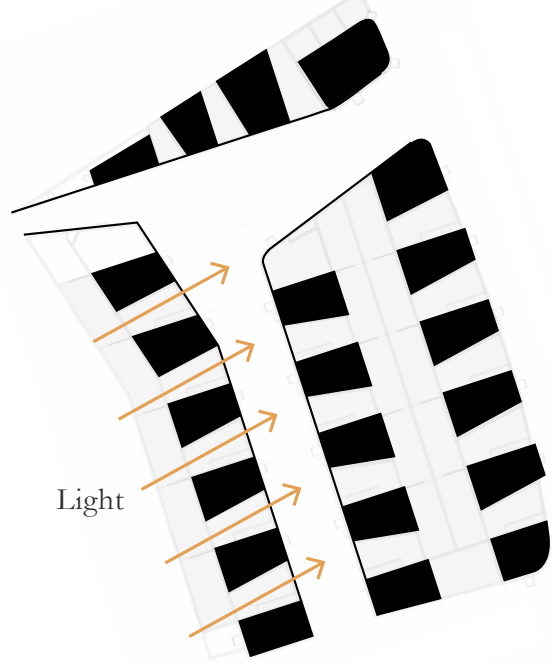

The post occupancy, pedestrian movement patterns show considerable movement through intimate internal street which is bordered on each side by two and three story buildings. At the intersection where the two streets broaden is a small tree lined square for residents and pedestrians.

Success of these paths can be credited to the design providing a positive definition to entry and exit with the 3 story buildings being used to frame these

points off from the main street.

The notched terraces create building cavities at every second interval on the 3rd level. Allowing light penetration for dwellings adjoining the cavity as well as allowing light to reach the street at ground level below.

$\wedge$

Figure 30 // WDonnybrook Quarter; notched terrace form and light penetration

\section{LEARNINGS + PRINCIPLES}

A. The degree of personal territory (Public,Semi Public, Semi Private, Private) varies according to how well the entrance is defined.

B. Scale and proportion of spaces - spatial relationships between the height of the buildings and width of the space between will inhibit or prohibit a feeling of comfort. This becomes important when placing built form on either side of streets, pathways or small parks. 


\title{
PRECEDENT REFLECTION
}

\author{
I N S UMMARY
}

The precedents were aimed at extending the body of knowledge discussed in previous literature review, to discover relevant thoughts and principles involved behind architectural and urban design relative to this project.

Further information was gained upon urban consolidation, new organisation of space, composition of built form relative to topography and the integration of natural ecologies in an urban environment and also demonstrated public life between built form. The projects cited were a useful step in learning from concepts outlined in the literary context. Across all precedents it was evident the importance in defining the street edge with the architecture. Analysis outlined the Norrebro Solund Homes in Copenhagen had the strongest strategies and intent for responding to each different scenario through organising both formal architectural setbacks, adapting the ground floor programme or making changes to the urban fabric by adding more public environments as interstitial space between the building and street.
A. Urban consolidation \& organization of space; one of the most important parameters for good urban design is for buildings to give positive definition to the shape and function of outdoor space.

B. Relations between Built Form and topography; how housing typlogies can be established which are a result of combining landscape types with built form.

C. Interactions between people and nature; ensuring vibrancy and quality of natural environments to act as strong trigger which prompts the desire for interaction, usability of spaces and physical and mental wellbeing.

D. An objective for the design and research is in facilitating a successful interaction between public and private to enhance the perception of community and ensuring quality public realm is retained and not sacrificed from the result of urban densification. 


$$
3
$$




\title{
DESIGN \& RESEARCH
}

\author{
Chapter containing a visual and written documentation \\ of the design process, detailing the site analysis and \\ design phases with critical reflection.
}




\section{E S I G N P R O C E S S}

This is a design-led document of research in which concepts significant to the research question have been identified and developed upon within the research and design process. It is an iterative method by which the work continues to develop at each stage and the goal of this section is to understand existing context, problems and opportunities around the project's four main components of;
o urban densification
o built form and topography
o natural ecology
o gradients of privacy

The configuration of work leads to a final design which is reflective of the process work conducted in the four main components of research. Response to a selected site and the specific location in Wellington the design outcome and process is considered a fundamental approach capable of being applied at a range of varied configurations and scales to achieve a design outcome.

$>$

Figure 31 // Diagram; design process 


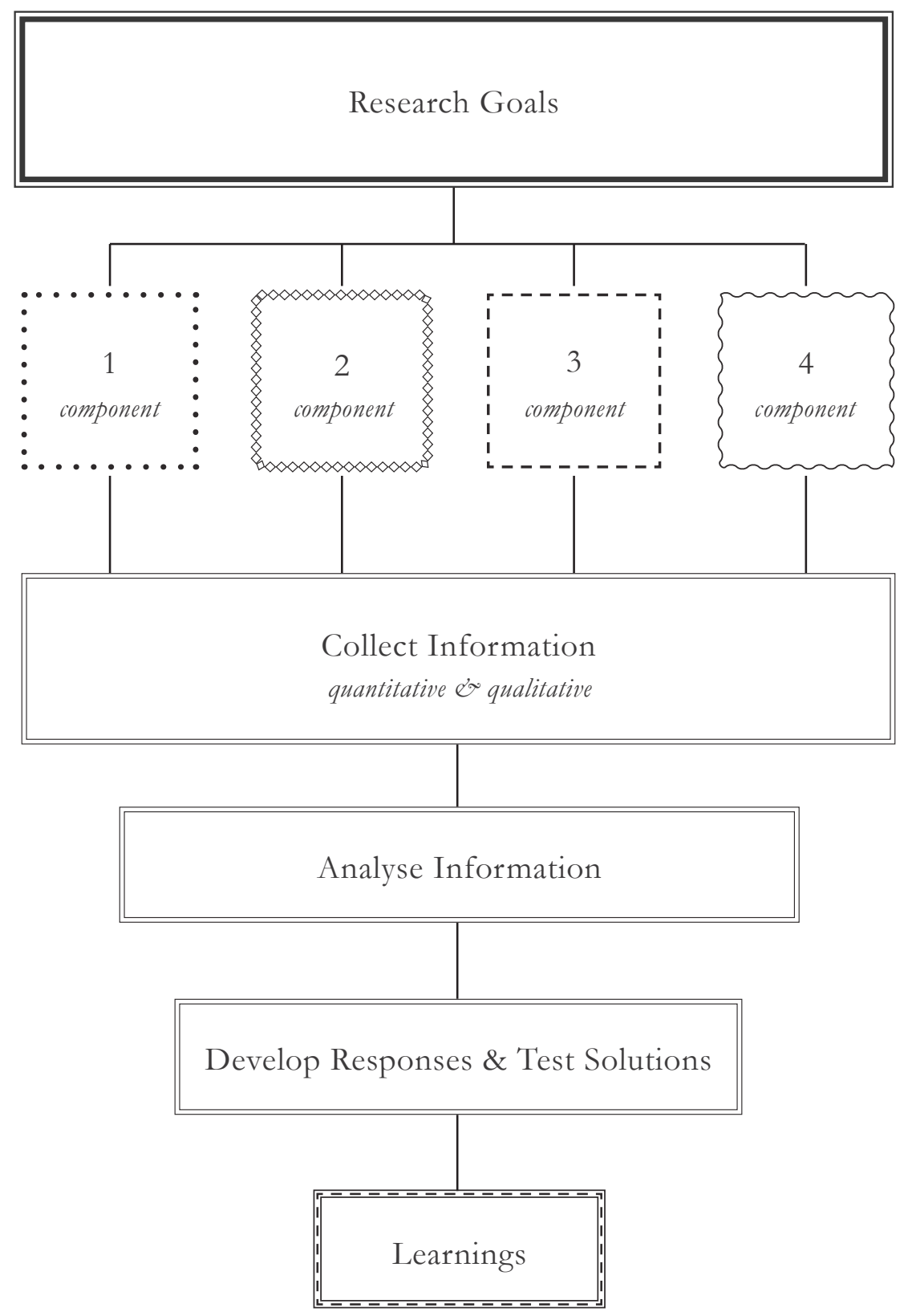




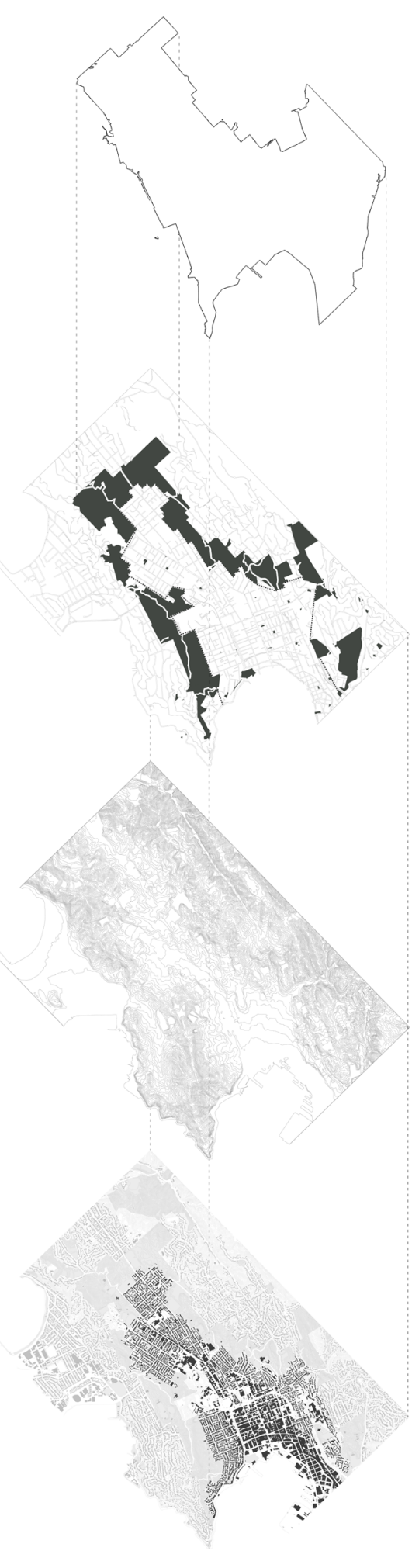

$\wedge$

Figure 32 // Axonometric; wellington city buildings, topography, town belt 


\section{SITE ANALYSIS}

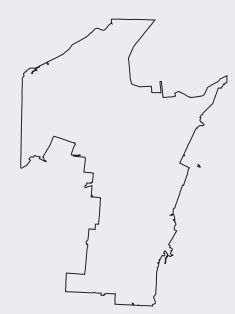

This sub section includes Site and Context analysis for the Wellington City region, containing documented visual and written research to convey the detailed site analysis.

The Site and Context analysis includes information upon the existing city context, inner city suburbs and population estimates, city transport, a town belt amenity analysis, and a topographical survey. The 5 topics covered have been considered as important information required for distinguishing an area for an urban densification and ensuring it is suitably located within the city fabric. Maps are diagrammatic and aim to convey information important to the research of this project. From this site and context analysis a final site is determined for the project. 


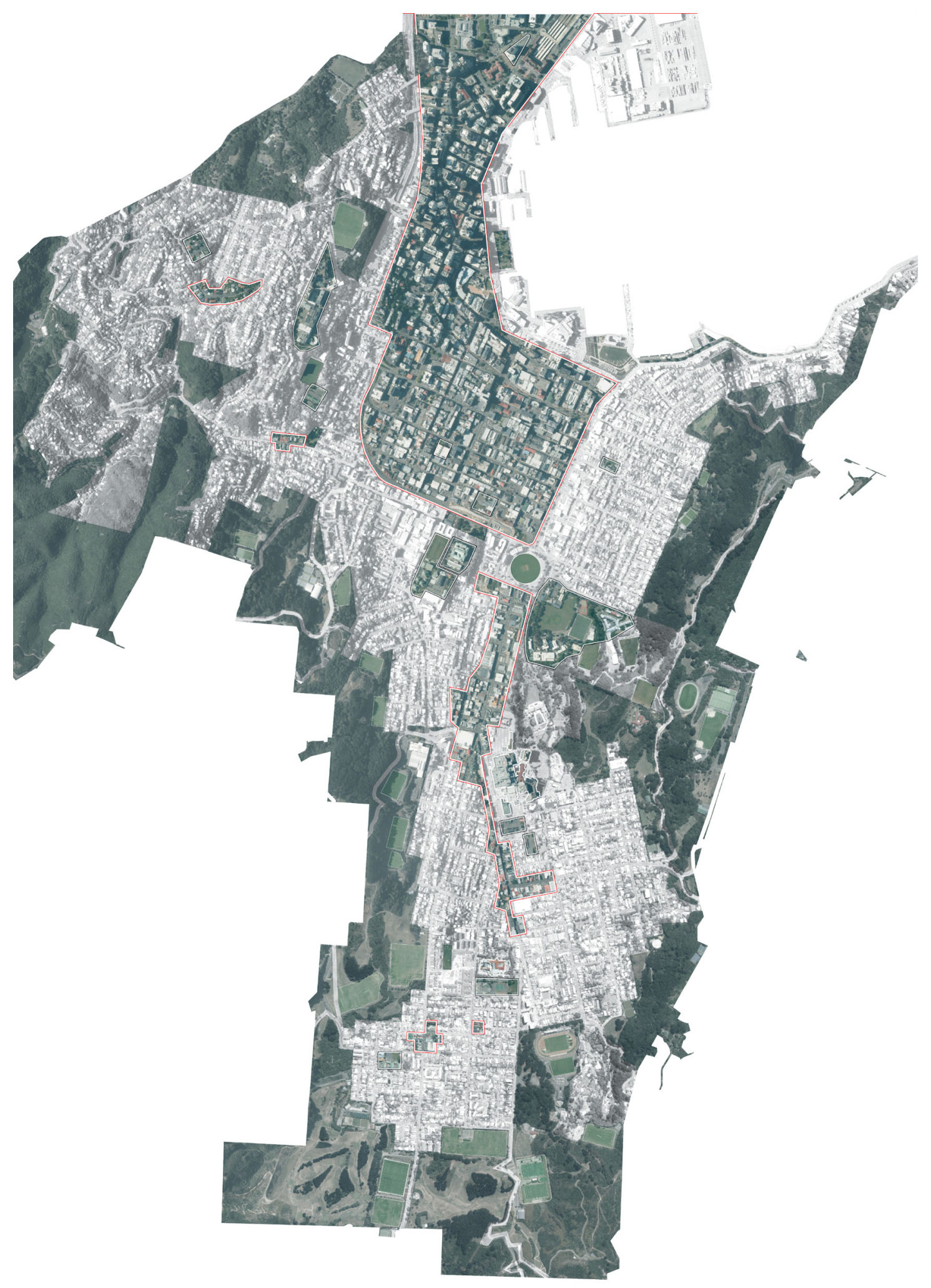

$\wedge$ 


\section{ONTEXT MAP}

The built environment consists of the physical structure and organization patterns of building blocks, neighborhoods, towns and cities.

A built environment undergoing urban densification requires the support of physical infrastructure, resources and operational components, which are essential to its functioning. (Coyle, Stephen. 6)

Increasing the number of people in an area can provide support many businesses and the local community. Amenities such as swimming pools, public libraries, local schools, hospitals, parks, public transport networks, and the commercial areas all benefit from a densely populated environment resulting in increased activity. (Betanzo, Mike)

This map looks at identifying existing context within the city, which contribute to and assist urban densification. City and Suburban centres can provide additional infrastructure and mixed use urban amenities for higher density urban environments.

The following have been mapped and considered as important infrastructure, which can support urban densification and have been located on the Context Map.

\section{LEGEND}

Urban Centres

Educational Facilities

Health Care Amenities

Recreational Park Land 


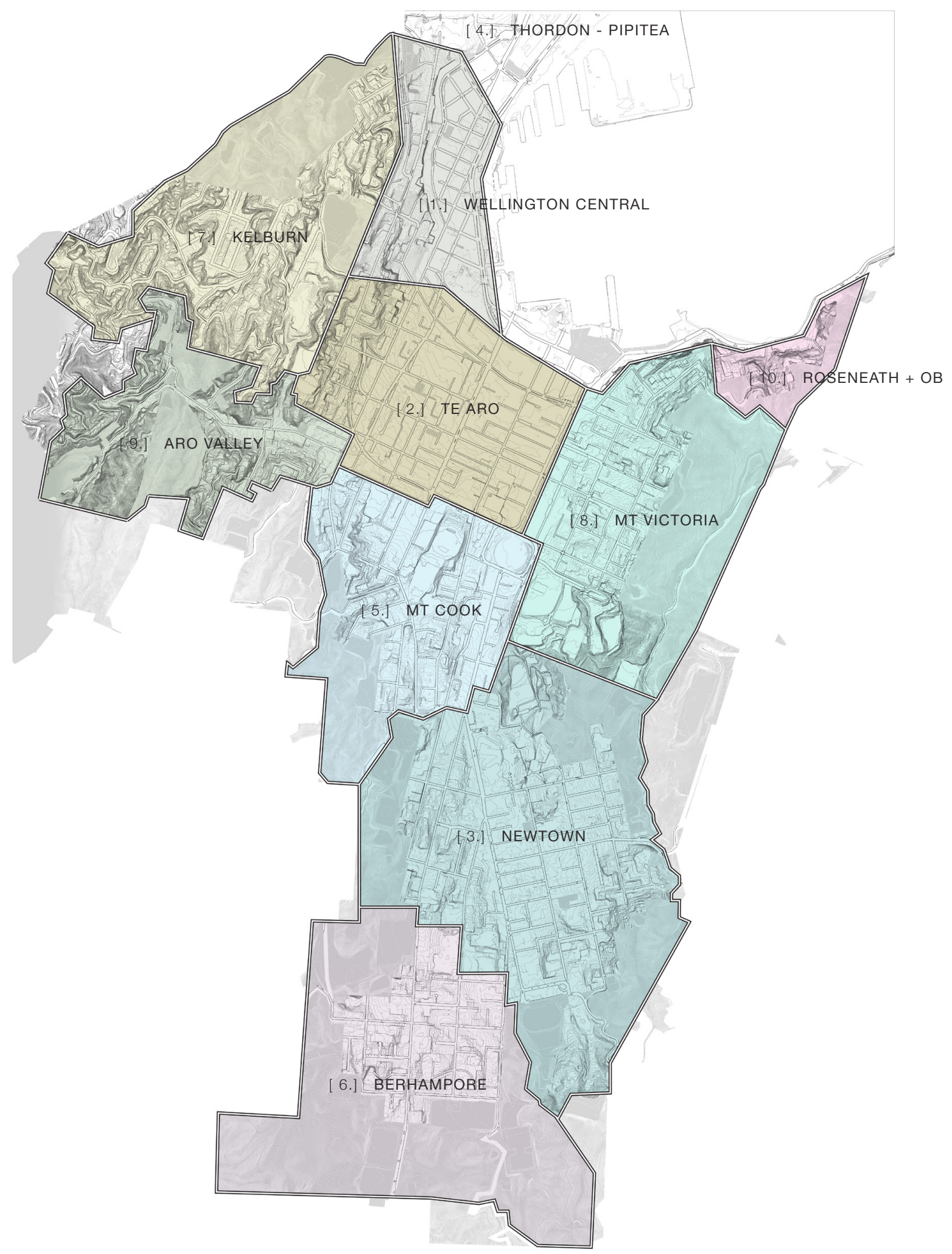

$\wedge$

Figure 34 // Wellington aerial; suburb population map 


\section{N N E R C IT Y POPULATION}

The inner city is the central area of a major city and the area tends to have a bigherpopulation density to that of outer suburbs with more of the population living inside multi-floored town houses and apartment buildings.

The purpose is to gather information about the general population, in order to present a full and reliable picture of the population in the suburbs within the city and the expected demands some areas are facing with regards to housing conditions and population increases.

Aside from Wellington Central and Te Aro, the central suburbs are expected to have the largest forecasted population growth by 2043 is Newtown (37.47\%), Thordon-Pipitea (29.42\%), and Mt Cook (28.95\%). Developing an urban intensification strategy in these areas could be considered beneficial for the city.

203,800

Wellington City's population in 2015

$19 \%$

Forecasted population growth by 2043

\section{$27 \%$}

Increase in number of dwellings by 2043

2.6

Average househould size Mt Cook 2043
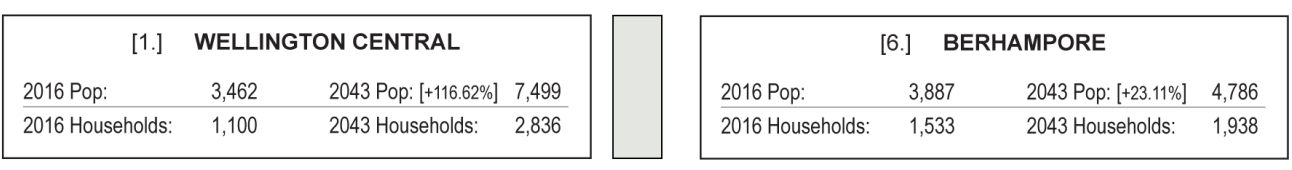

\begin{tabular}{|llll|}
\hline & {$[2]$.} & TE ARO & \\
2016 Pop: & 11,339 & 2043 Pop: $[+73.26 \%]$ & 19,647 \\
\hline 2016 Households: & 3,839 & 2043 Households: & 7,890 \\
\hline
\end{tabular}
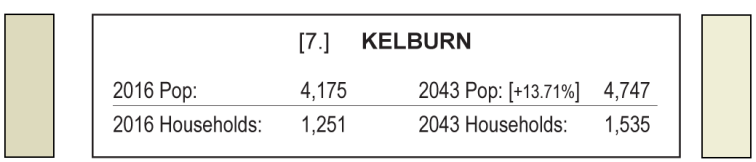

\begin{tabular}{|c|c|c|c|}
\hline \multicolumn{4}{|c|}{ [3.] NEWTOWN } \\
\hline 2016 Pop: & 9,123 & 2043 Pop: [+37.47\%] & 12,541 \\
\hline 2016 Households: & 3,255 & 2043 Households: & 4,686 \\
\hline
\end{tabular}
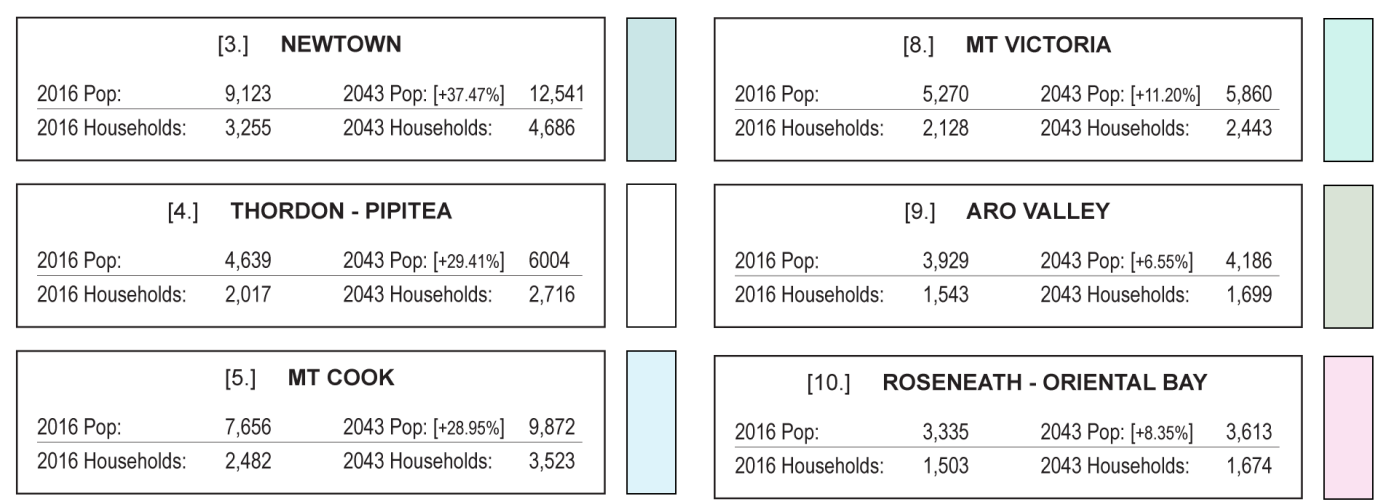


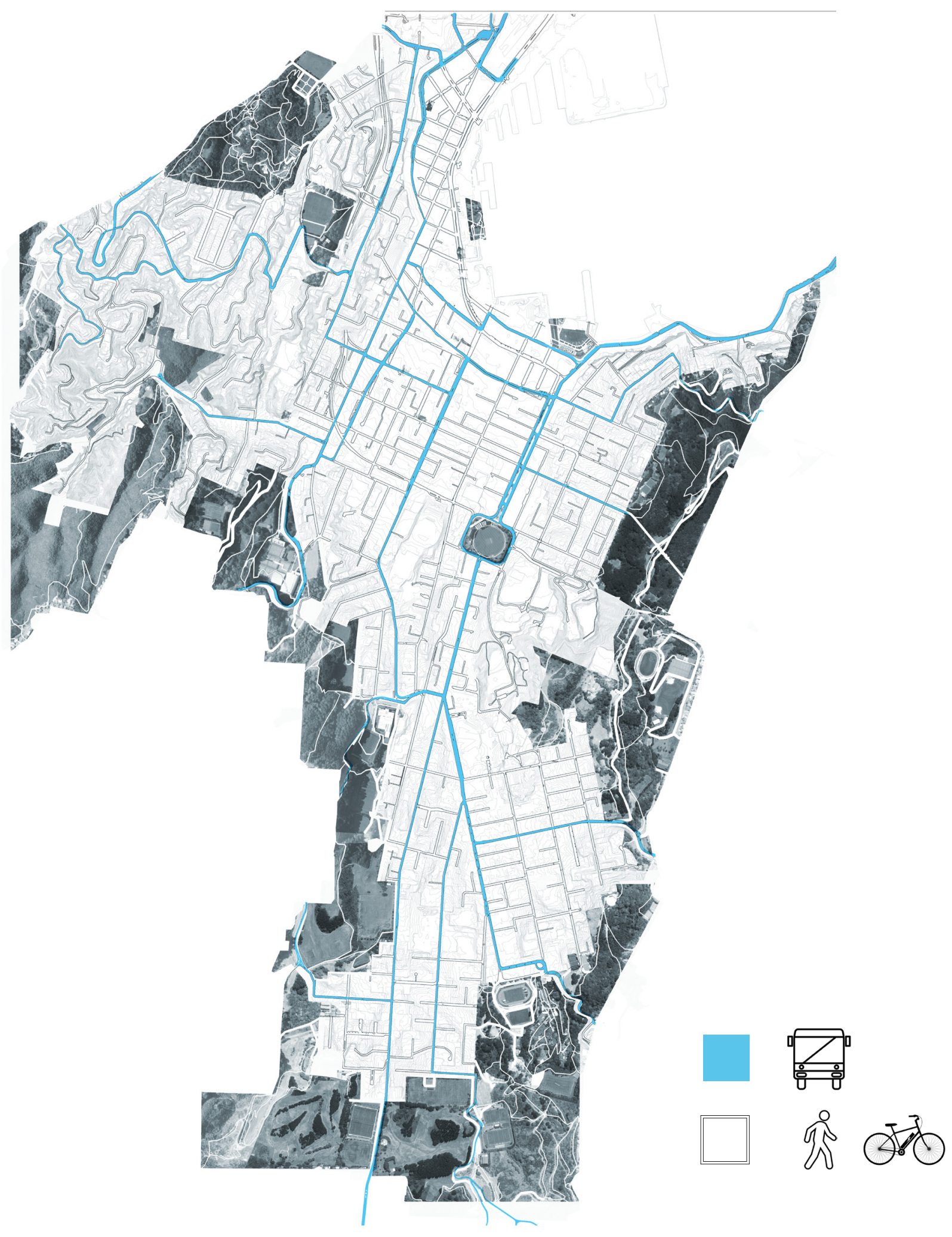

$\wedge$

Figure 35 // Wellington aerial; city circulation map 


\section{T R A N S P O R T}

Having an urban intensification scheme directly linked in close vicinity to public transport nodes makes accessing the city easier for residents and places less demands on the requirements for private car ownership.

Wellington's hilly terrain has considerable affect on public transport. Wellington can be considered a good city for public transport utilizing around 470 buses within the region. The topography of the city concentrates dense corridors for transport routes through valleys or along coastlines passing through suburban and city centres.

GIS information indicates that $77 \%$ of the region's population lives within 800 meters radius of a public transport stop and will have to wait at the most of 30 minutes before catching a ride. (WCC)

Some of the main benefits of higher density environments is the reduction of private car travel. On a city-wide scale, areas with higher densities, accessible land and connected transport options demonstrate less reliance on private car ownership. (Miko Betanzo) These higher density areas show greater numbers of people walking, using public transport, cycling and spending less time commuting.

\section{$25 \%$}

Increase in number of people using buses

\section{$17 \%$}

Wellington residents walk to work (5\% nationally)

\section{$5 \mathrm{~km}$}

Average commute distance to work

\section{$65 \%$}

Residents use public transport, walk or cycle into the city
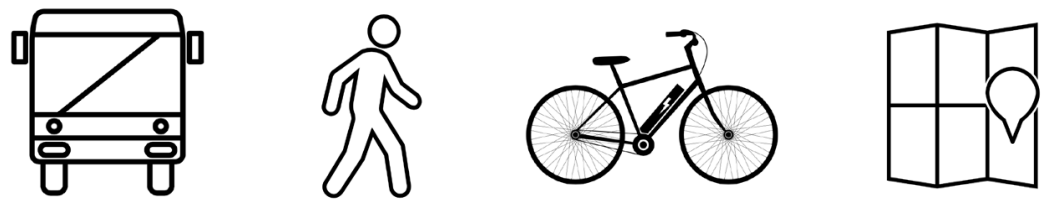


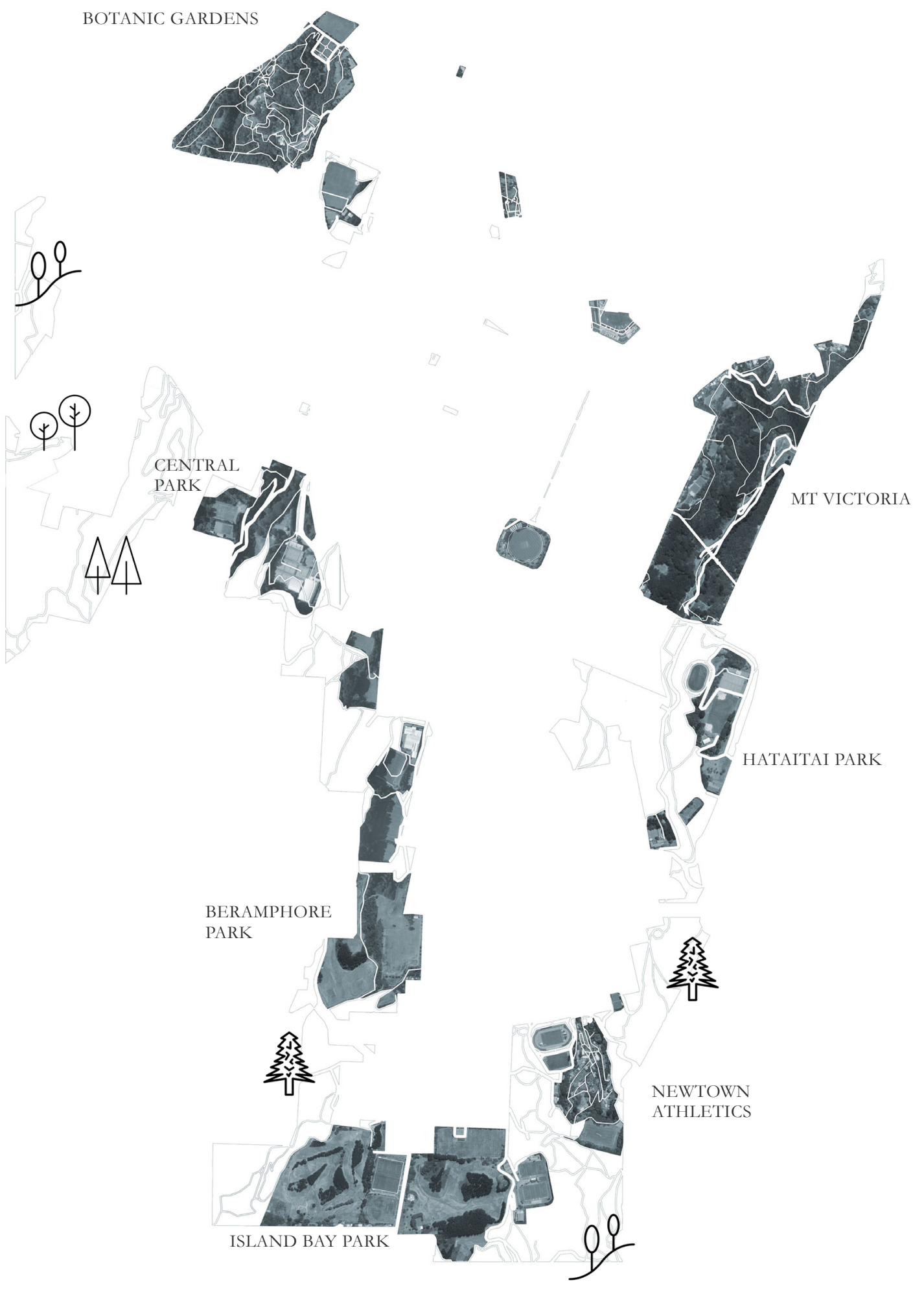

$\wedge$ 


\section{W ELLINGTON TOWN B ELT}

The Wellington City Town Belt is a significant part of Wellington and has played a critical role in both shaping a sense of place and defining the city's geographical identity.

Combined, the reserves and parkland create a large area of open space which acts as a scenic back drop to the inner city as well as providing recreational opportunities for visitors and residents. Over the last 170 years the belt has stretched in a horseshoe shape from Mount Victoria in the North-East back down and around towards Thorndon in the North-West consisting of around 520 hectares of land.

The entirety of the Town Belt has been drawn and this analysis highlights, in colour, all public areas located on the Town Belt that can easily be accessed by the public. This includes key public amenities such as;

\section{$\underline{\text { Colour }}$}

- Parks, reserves, vegetated slopes visible from both the central city and from external suburbs

- A large range of sporting and recreational activities including football parks, velodromes, botanical gardens and walking tracks.
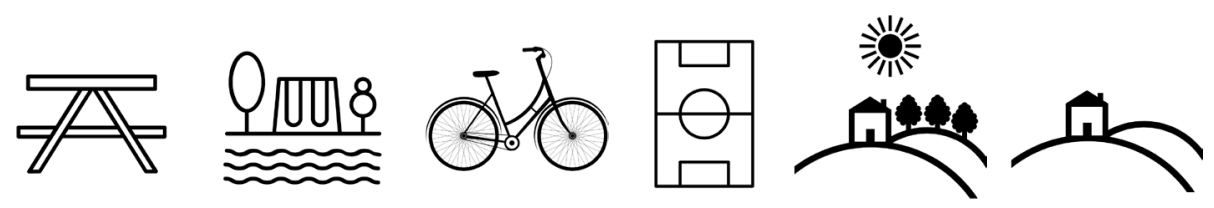

The remaining land acts as a continuous horseshoe form of undeveloped hills between the central city and surrounding suburbs.
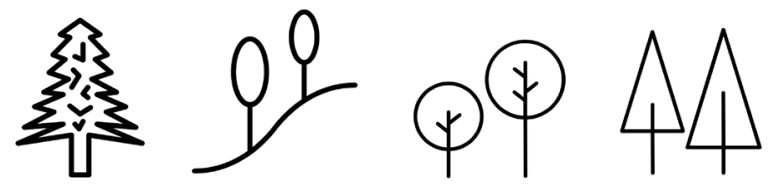

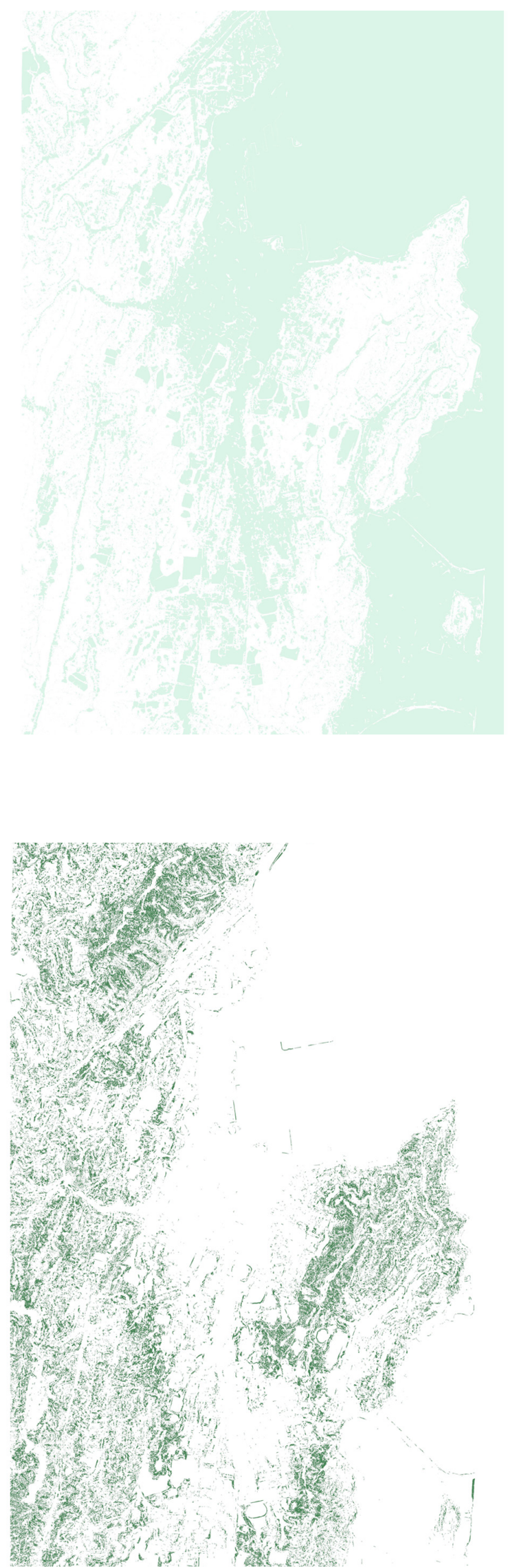
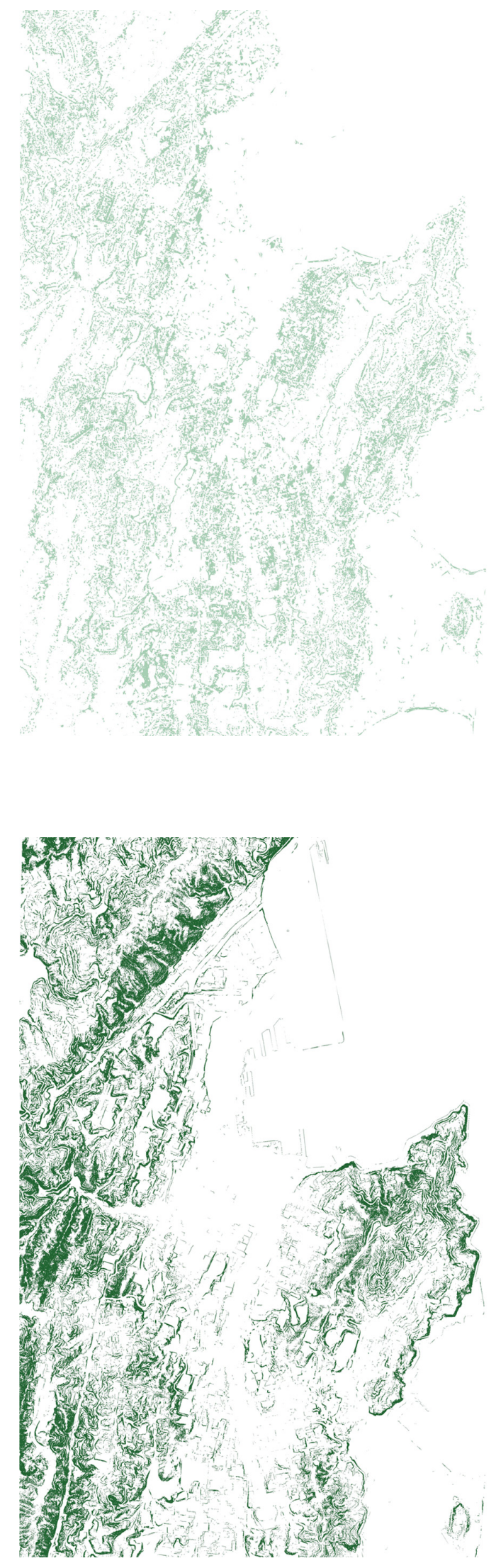


\section{TOPOGR A PHIC S URVEY}

The hills encircling the inner city form the capital's Town Belt which provides a unique edge condition to the urban fabric by enclosing the city and central suburbs.

The topographical condition presents itself as a continuous green sweep of native vegetation and parkland providing an important part of Wellington's landscape and geographical identity. Effectively, the central city and suburbs rest within a basin surrounded by hills as the topography slopes upwards and outwards towards the encircling town belt.

The composition of flatter plains at the centre with sloping hills either side creates a wide range of topographical situations that vary across the city's geography. Large scale topographic meshes help identify different steepness's in slopes.

\section{$355 \mathrm{~km}$}

Council managed tracks and walkways in the city's open space areas.

\section{$200 \mathrm{~m}^{2}$}

Green open space per resident, compared to $5 \mathrm{~m}^{2}$ per resident in Japan.

\section{LEGEND}
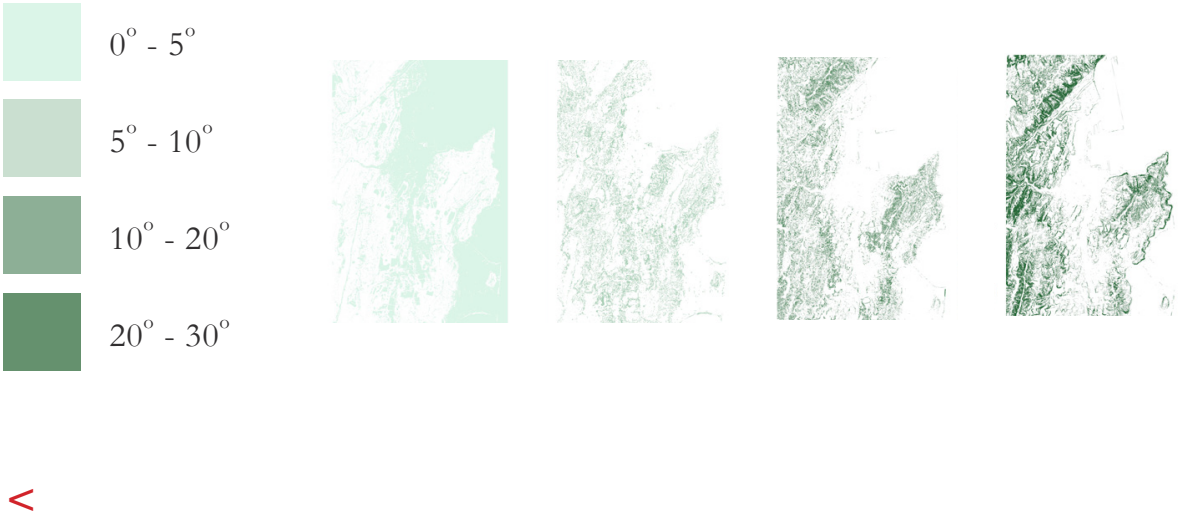

Figure 37 // Wellington aerial; GIS contour slope maps 


\title{
SITE ANALYSIS REFLECTION
}

\author{
I N S UMMARY
}

The Site Analysis evaluated important information that was required to distinguish an area for urban densification. Any density increase must be carefully considered alongside quality design, land-use, accessibility and greater connectivity, which is why the various mapping of information was used to help distinguish a decision. (Opher, Philip) Important information gained from this exercise were;

Built environments undergoing densification require the support of physical infrastructure and resources to assist in the functioning of a densely populated area. For example, a small convenience store might be suitable to source resources for a block of residents. If this block of residents increases by $150 \%$ the resources available from the small convenience store might become insufficient. Densification would be more appropriate and suitable around an area with a stronger and more thriving infrastructure that residents can readily access.

Through information analysed and gathered from the Wellington City Council there were three inner city suburbs noted as appropriate areas to target for developing urban intensification. These central suburbs had the largest forecasted population growth and were as follows;

A considerable benefit of higher density environments is reducing private car travel. Higher density areas show greater numbers of residents walking, cycling and utilizing public transport. Therefore, ensure urban intensification schemes are directly linked in close vicinity to public transport nodes. This simple intent makes accessing the areas in the city easier for residents and creates less demand on the requirements for private car ownership as well as making more destinations and amenities accessible by non-drivers. 


\section{CONTINUED. REFLECTION}

More intensive land use has the side effect of reducing green spaces and trees. It is not always a requirement to retain greenery however this project plans for the quality integration of usable green space and tree planting. Mapping and locating public areas around the town belt helps identify areas that can provide an abundance of vegetation and quality open green space that residents can utilise despite living in a denser environment. However, working with the vegetated slopes also provides challenges in locating urban and built form around natural occurring ecologies and landforms. 


\title{
DETERMINED SITE
}

\author{
Rolleston Street. Mt Cook \\ Prince of Wales Park, Wellington Town Belt
}

The site was determined by evaluating information from each component of the Site and Context analysis. It was important that the selected site either currently responded to or had the opportunity to connect with each of the five topics used for analysis. This ensures the final decision to an area that would be able to accommodate an urban densification and test research \& design strategies upon.

The Rolleston Street block in Mt Cook was decided for existing qualities and opportunities because of;

o Close vicinity to infrastructure that can support a denser population. City centre (north) and short walking distance to Newtown town centre (east)

o Noted as an appropriate inner city suburb for urban densification due to its high forecast of $29 \%$ population growth across the next 25 years - developing a densification strategy here would be considered beneficial for the city.

o Close vicinity to town centres makes accessing public transport simple for residents.

o City bus route located adjacent to site.

o Close vicinity to open green spaces and vegetated parkland which residents can use as communal outdoor space while living in denser environments.

o Sloped topography encourages opportunities for research and design into combining built form with landscape 

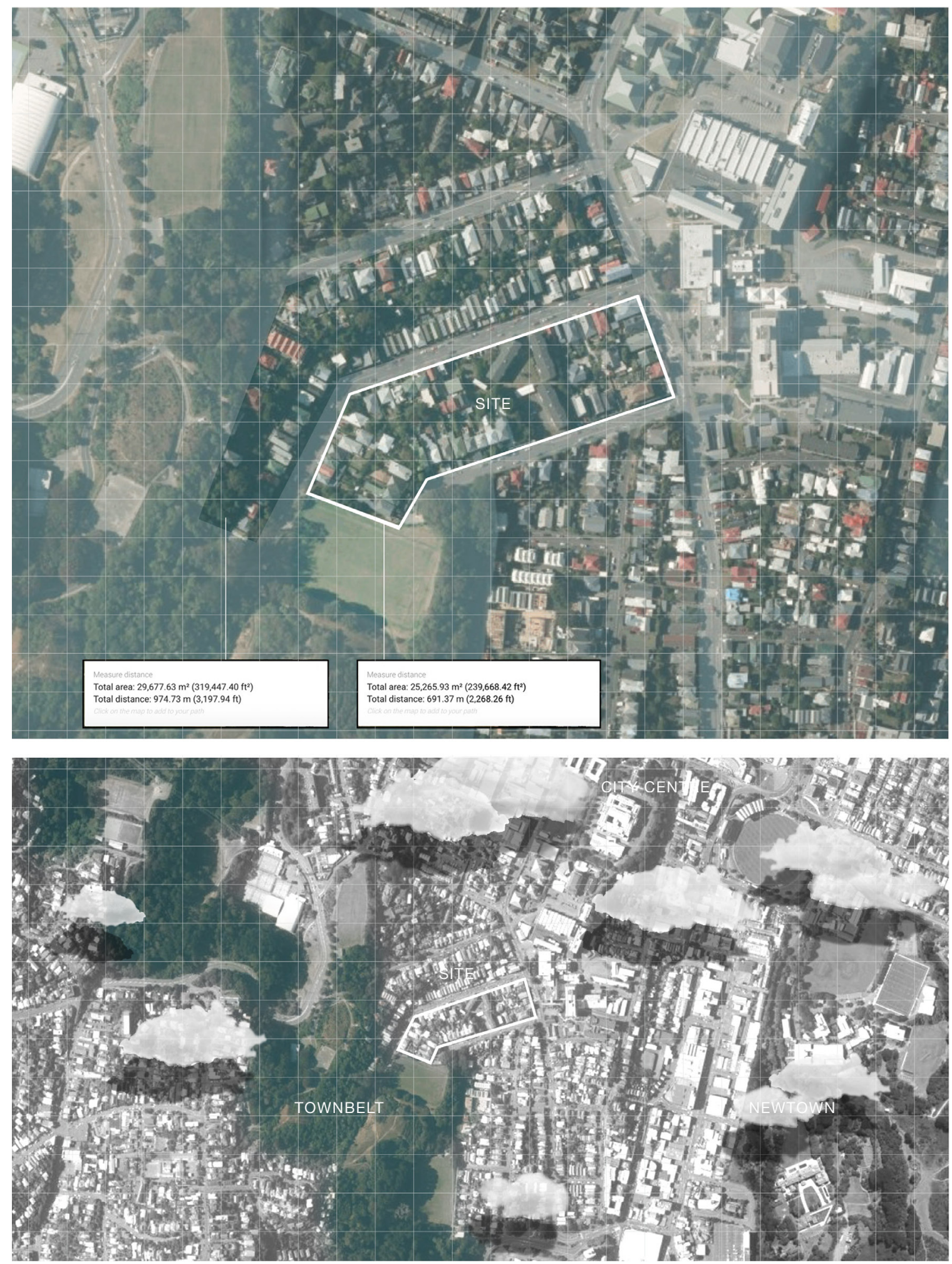

$\wedge$

Figure 38 // Wellington aerial; determined site

$69 \quad$ Figure 39 // Wellington aerial; town belt context 


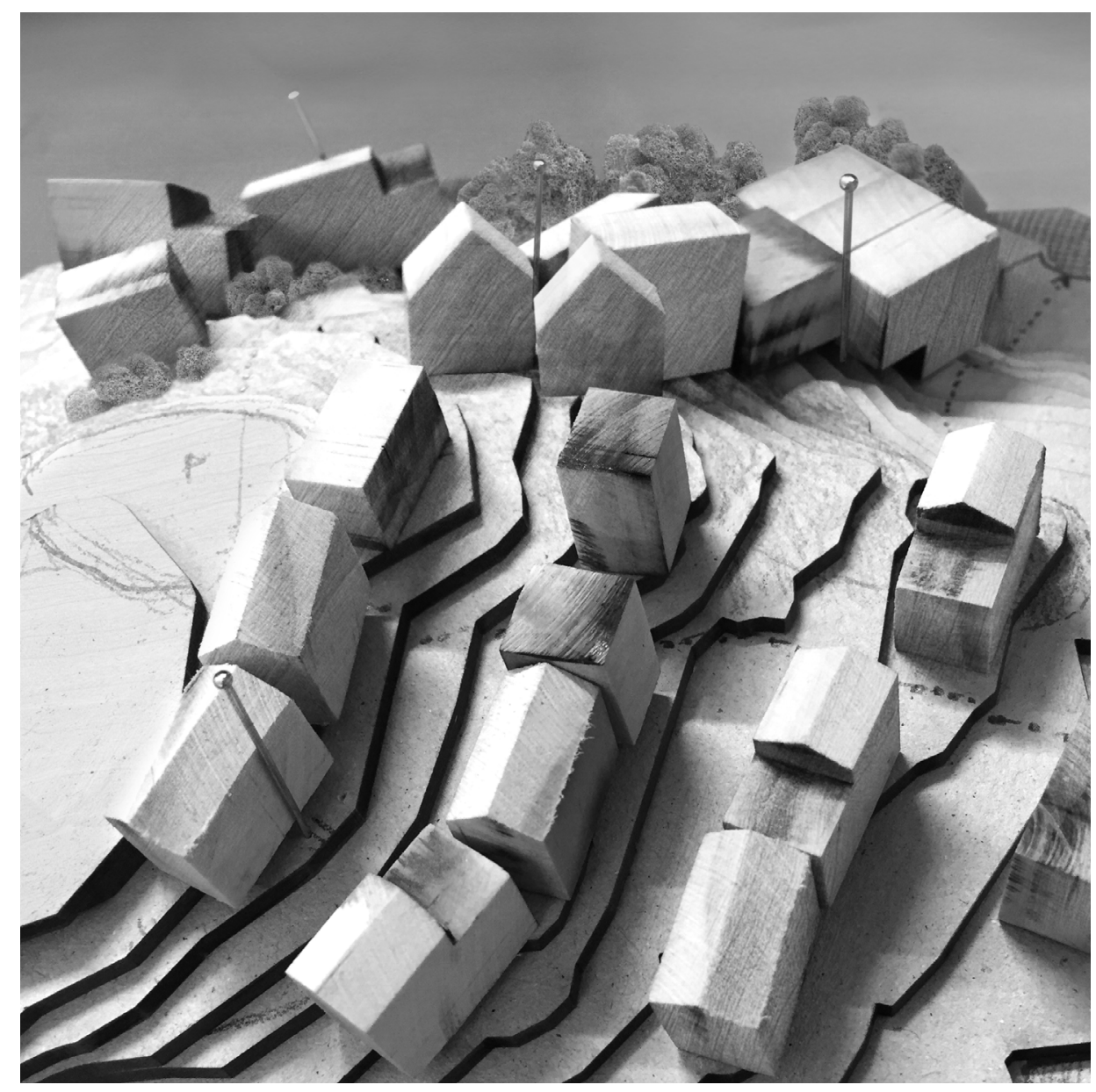




\section{E N S I T Y A N A L Y S I S}

It is clear that by increasing density - the number of people per unit area - many economic, environmental and social benefits can be realised.' Miko Betanzo

The following Density Analysis is aimed at gaining quantitative information and research regarding the Rolleston Street site to make informed decisions upon appropriate urban consolidation. Dwellings per hectare (dph) will be referred to as a common measurement used to help compare density.

This section begins with an overview of the existing density and dwelling types on the site. Following this are investigations that inform and calculate suitable increases in net density with diagrammatic analyses into the effects increasing built form has on site coverage. 


\title{
EX IS T ING D W E L L ING T Y PES
}

An initial overview was conducted which identifies the four main dwelling types occupying the site. This study was done by measuring building footprints to distinguish approximate floor areas of each dwelling type. There is an even amount between one to two story houses ( 45 dwellings) with suburban subdivisions and a social housing complex consisting of three apartment buildings (54 dwellings).

Pages 74-75 show diagrams of existing dwelling types highlighted on site

Pages 76-77 has quantitative information of each dwelling's approximate floor area based upon building footprint and dwelling type. This provides information required to calculate dph and the total floor area (constructed surface) of the entire housing stock on site.
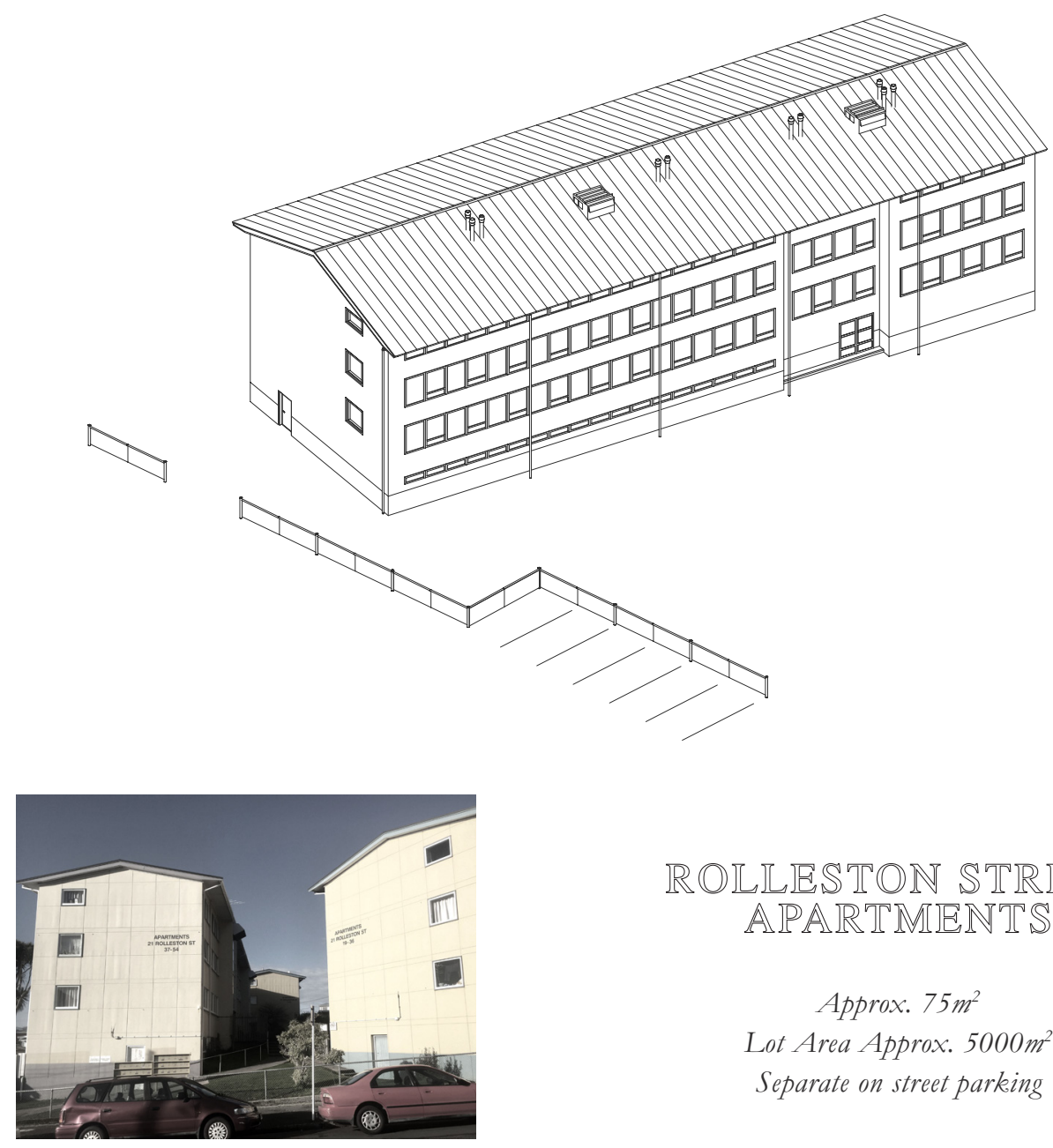

\author{
$\mathbb{R} O L I \mathbb{L} \mathbb{S} \mathbb{T} O \mathbb{N} \mathbb{S} \mathbb{R} E \mathbb{E} T$ \\ $\mathbb{A} \mathbb{P} \mathbb{R} \mathbb{R} \mathbb{M} \mathbb{N} T \mathbb{S}$ \\ Approx. $75 \mathrm{~m}^{2}$ \\ Lot Area Approx. $5000 \mathrm{~m}^{2}$ \\ Separate on street parking
}




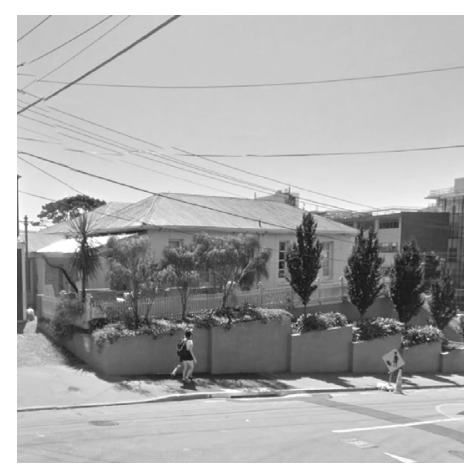

1 STOREY HOUSE Approx. $120 \mathrm{~m}^{2}-230 \mathrm{~m}^{2}$

Lot Area Approx. 400 ${ }^{2}$ Detached Garage

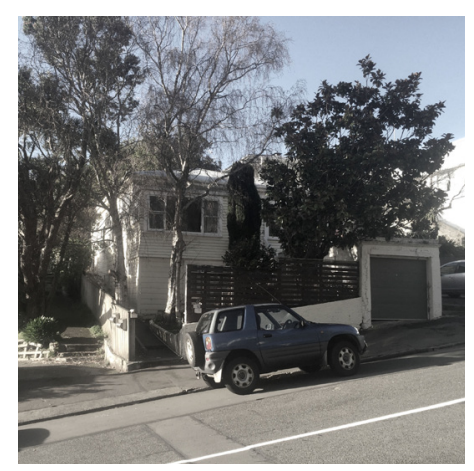

2 STOREY HIOUSE Approx. $104 m^{2}-224 m^{2}$ Lot Area Approx. $340 \mathrm{~m}^{2}$ Detached Garage

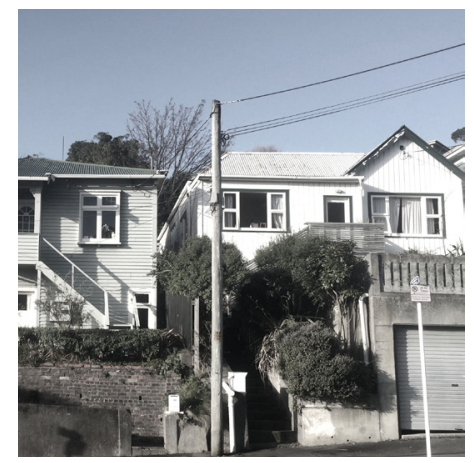

2 STOREY HOUSE Approx. 104m² - 224m Lot Area Approx. $340 \mathrm{~m}^{2}$ Detached Garage
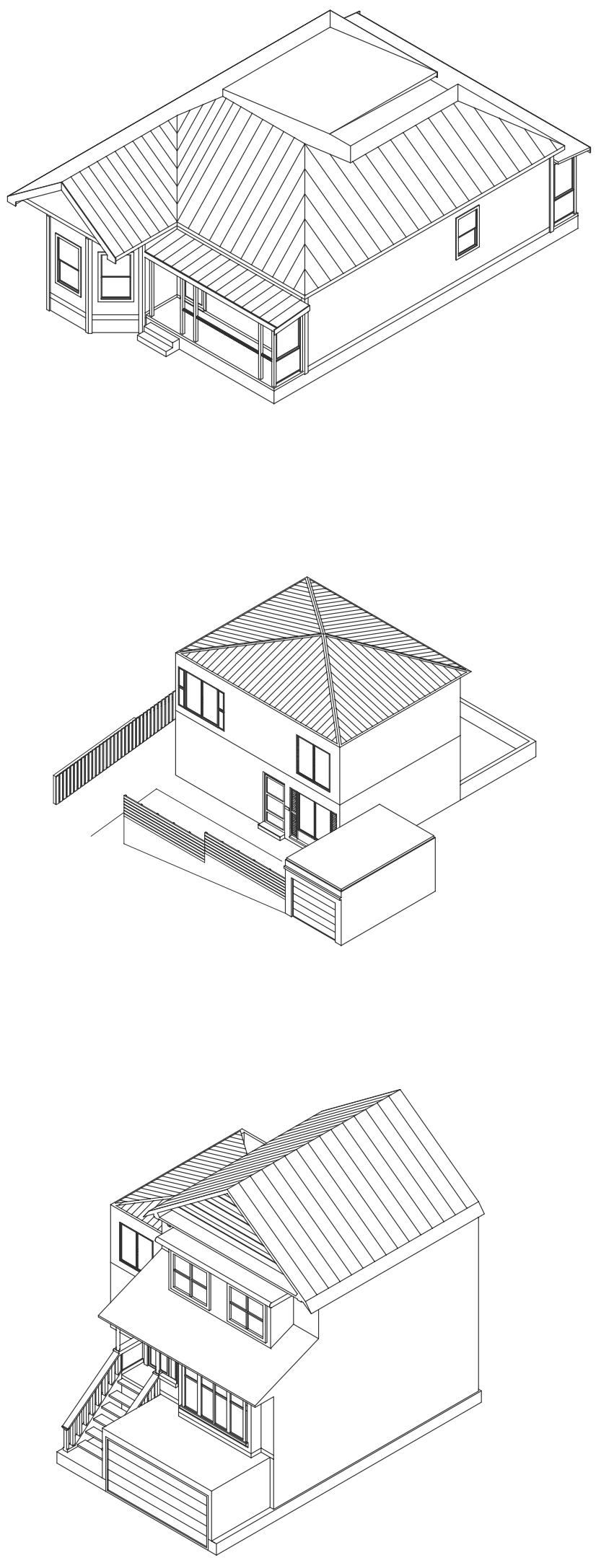

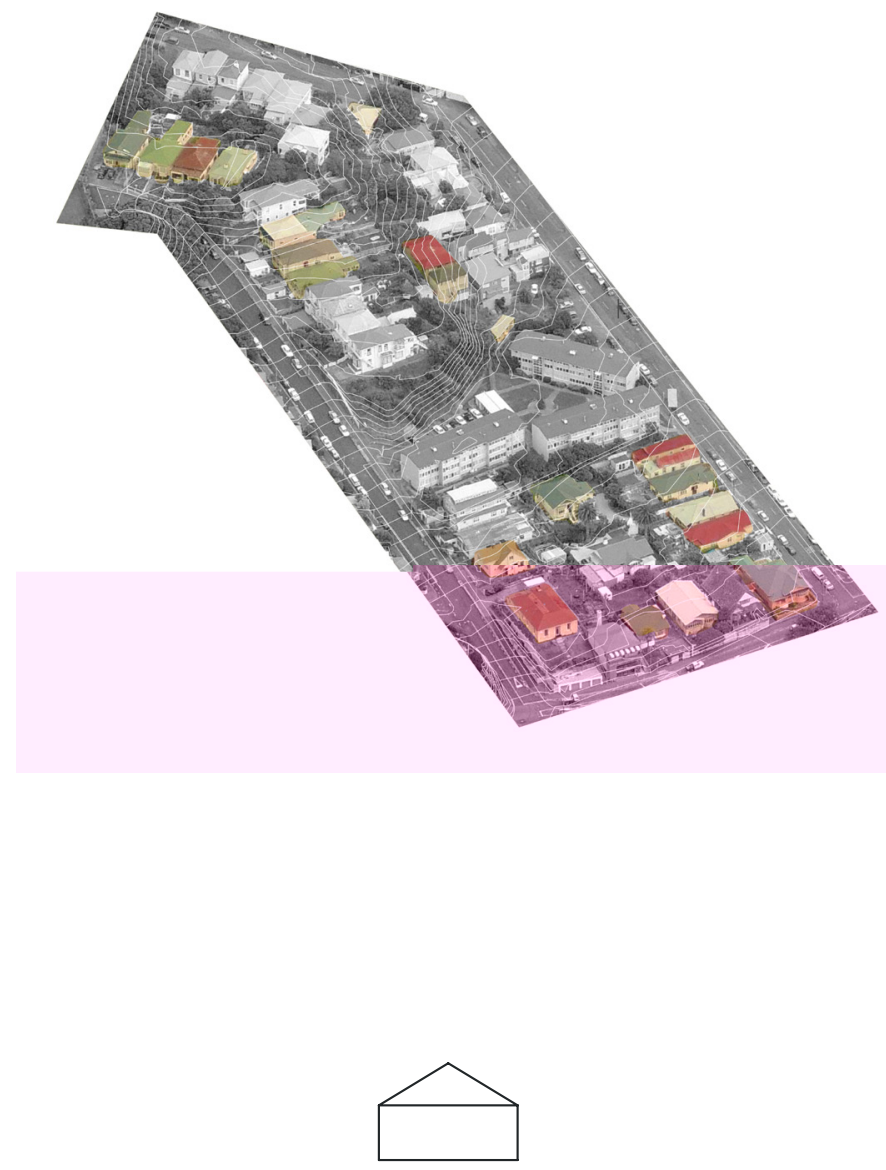

$\mathbb{1} S T O R \mathbb{E}$

20 DWELINGS / 25dph

GF Plot Cover: $3500 \mathrm{~m}^{2}\left(11,482 \mathrm{ft}^{2}\right)$

GFA: $3500 \mathrm{~m}^{2}\left(11,482 \mathrm{ft}^{2}\right)$

Parking: Detached Garage
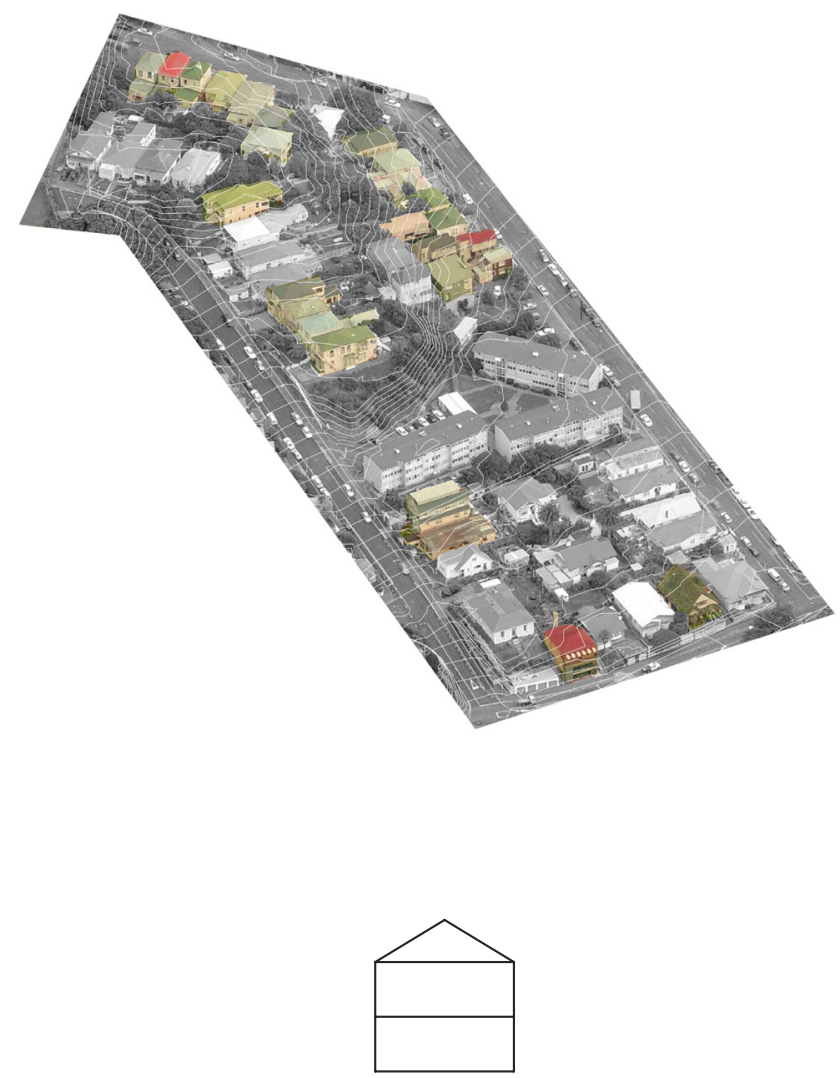

2 STOREY

25 DWELLINGS / 25dph

GF Plot Cover: $3120 \mathrm{~m}^{2}\left(10,236 \mathrm{ft}^{2}\right)$

GFA: $6000 \mathrm{~m}^{2}\left(19,685 \mathrm{ft}^{2}\right)$

Parking: GF Garage

$\wedge$

Figure 45 // Density Type Axonometric; One Storey

Figure 46 // Density Type Axonometric; Two Storey 

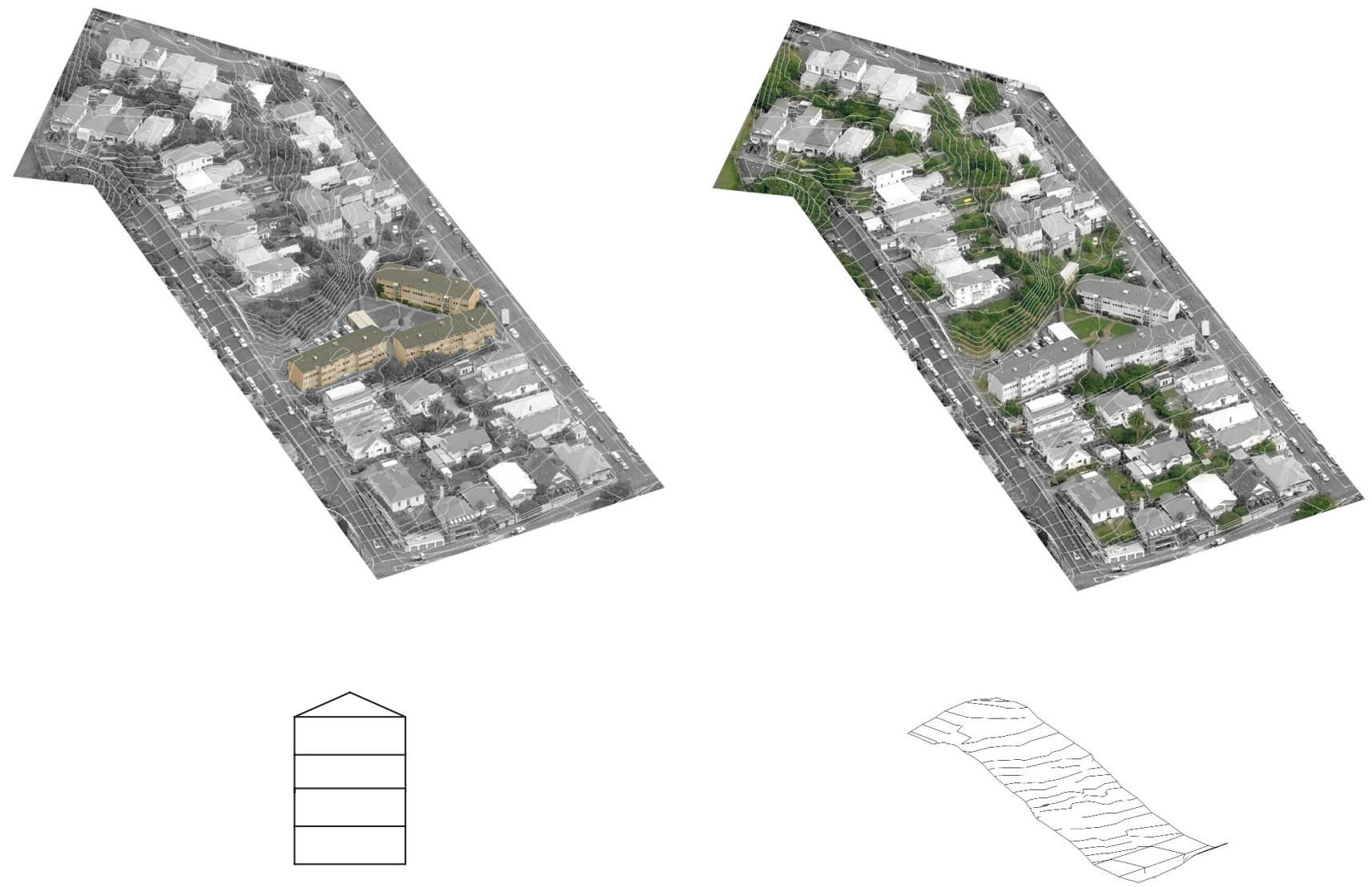

ROLLESTON ST $A P A R T M E \mathbb{N} S$

SITE COVERAGE

54. UNITS / 100dpl h

Apartment Buildings ( 3 )

Unit GFA: $80 \mathrm{~m}^{2}\left(262 \mathrm{ft}^{2}\right)$

Parking: Separate on street parking
$25,000 \mathrm{~m}^{2}$ SITE COVERAGE

Building GF Coverage of Site: $8500 \mathrm{~m}^{2}$ ( $\left.34 \%\right)$ Average Lot Size: $520 \mathrm{~m}^{2}$ ( $1706 \mathrm{ft}^{2}$ )

Parking: On street parking

$\wedge$

Figure 47 // Density Type Axonometric; Rolleston Street Apartments Figure 48 // Density Type Axonometric; site coverage 


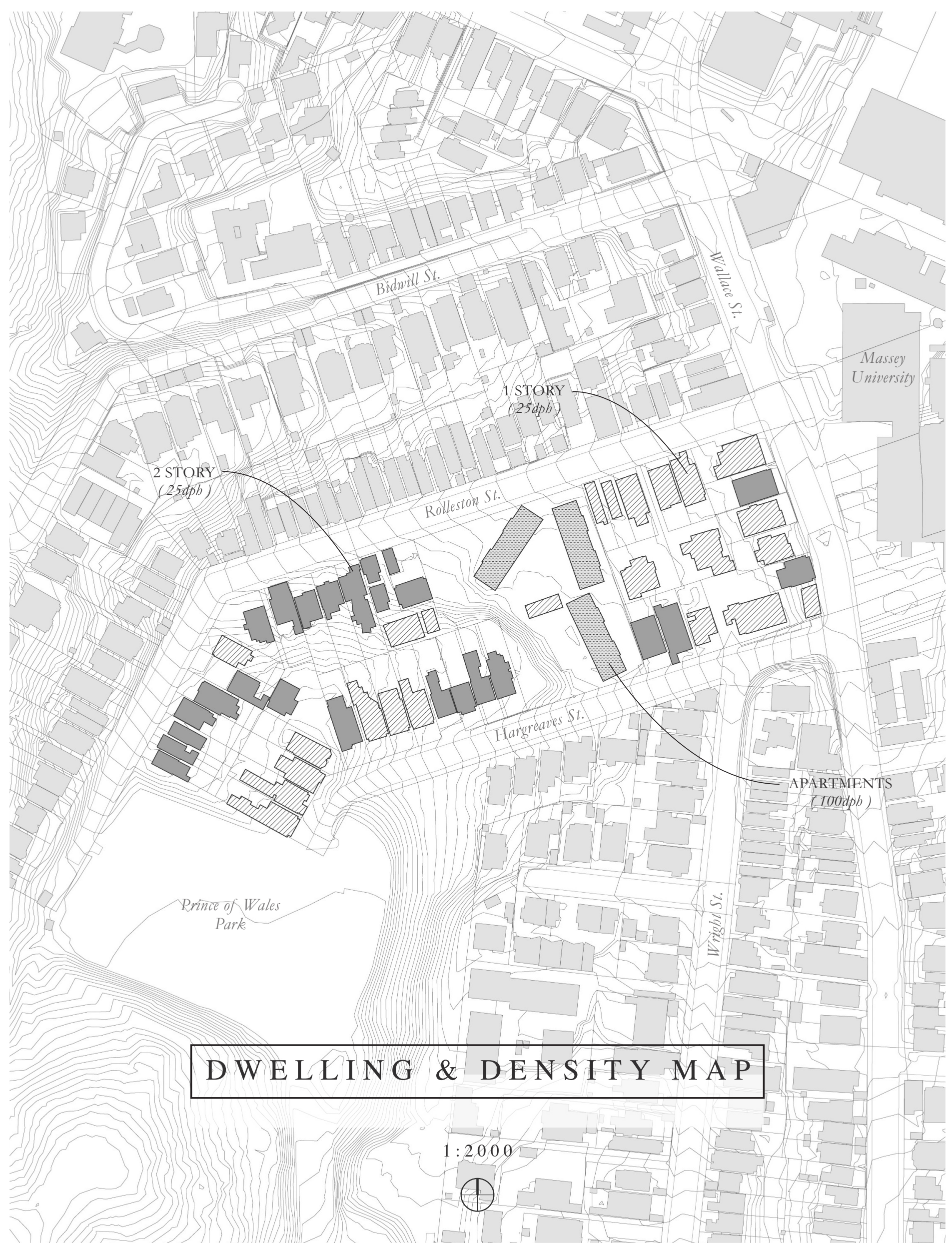


$\mathbb{I}$ STOREY (ON SITE)

\begin{tabular}{|cccccccc|}
\hline 1. & $65 \mathrm{~m}^{2}$ & 6. & $135 \mathrm{~m}^{2}$ & 11. & $160 \mathrm{~m}^{2}$ & 16. & $190 \mathrm{~m}^{2}$ \\
2. & $65 \mathrm{~m}^{2}$ & 7. & $140 \mathrm{~m}^{2}$ & 12. & $160 \mathrm{~m}^{2}$ & 17. & $200 \mathrm{~m}^{2}$ \\
3. & $75 \mathrm{~m}^{2}$ & 8. & $140 \mathrm{~m}^{2}$ & 13. & $170 \mathrm{~m}^{2}$ & 18. & $210 \mathrm{~m}^{2}$ \\
4. & $120 \mathrm{~m}^{2}$ & 9. & $150 \mathrm{~m}^{2}$ & 14. & $180 \mathrm{~m}^{2}$ & 19. & $230 \mathrm{~m}^{2}$ \\
5. & $120 \mathrm{~m}^{2}$ & 10. & $160 \mathrm{~m}^{2}$ & 15. & $190 \mathrm{~m}^{2}$ & 20. & $230 \mathrm{~m}^{2}$ \\
\hline
\end{tabular}

\section{$2 \mathbb{S T O R E Y ( O N ~ S I T E )}$}

\begin{tabular}{|cccccccccc|}
\hline 1. & $104 \mathrm{~m}^{2}$ & 6. & $144 \mathrm{~m}^{2}$ & 11. & $192 \mathrm{~m}^{2}$ & 16. & $200 \mathrm{~m}^{2}$ & 21. & $208 \mathrm{~m}^{2}$ \\
2. & $104 \mathrm{~m}^{2}$ & 7. & $152 \mathrm{~m}^{2}$ & 12. & $192 \mathrm{~m}^{2}$ & 17. & $200 \mathrm{~m}^{2}$ & 22. & $216 \mathrm{~m}^{2}$ \\
3. & $128 \mathrm{~m}^{2}$ & 8. & $152 \mathrm{~m}^{2}$ & 13. & $200 \mathrm{~m}^{2}$ & 18. & $208 \mathrm{~m}^{2}$ & 23. & $216 \mathrm{~m}^{2}$ \\
4. & $136 \mathrm{~m}^{2}$ & 9. & $176 \mathrm{~m}^{2}$ & 14. & $200 \mathrm{~m}^{2}$ & 19. & $208 \mathrm{~m}^{2}$ & 24. & $216 \mathrm{~m}^{2}$ \\
5. & $144 \mathrm{~m}^{2}$ & 10. & $192 \mathrm{~m}^{2}$ & 15. & $200 \mathrm{~m}^{2}$ & 20. & $208 \mathrm{~m}^{2}$ & 25. & $224 \mathrm{~m}^{2}$ \\
\hline
\end{tabular}

\section{ROLLESTON ST APARTMENTS (ON SITE)}

54 Units $\quad 75 \mathrm{~m}^{2}$

\section{MT COOK HOUSES (SEPARATE TO SITE)}

2428 Dwellings 


\section{$\mathbb{M T T} \mathbb{C O O K ~ H O U S I N G ~}$}

Total population in 2013 for Mt Cook was estimated as 7,118 people. An estimated increase of 1,300 people to 8,454 by 2028 . This is an average annual growth rate of $1.15 \%$. This information is based upon the increase of 530 households during the period. The average number of people per household is expected to fall from 2.64 to 2.60 by 2028. Therefore growth must occur in the number of dwellings for residents to live in to maintain population growth. (Wellington City Council)

2013
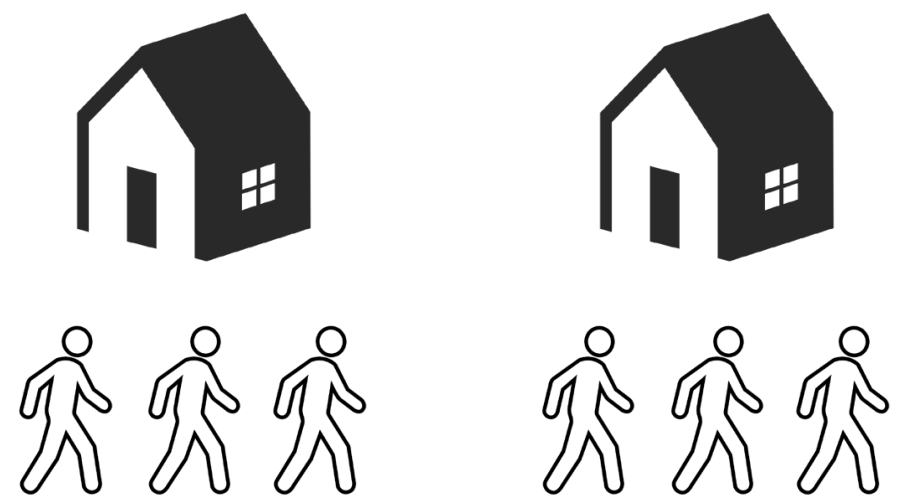

2043
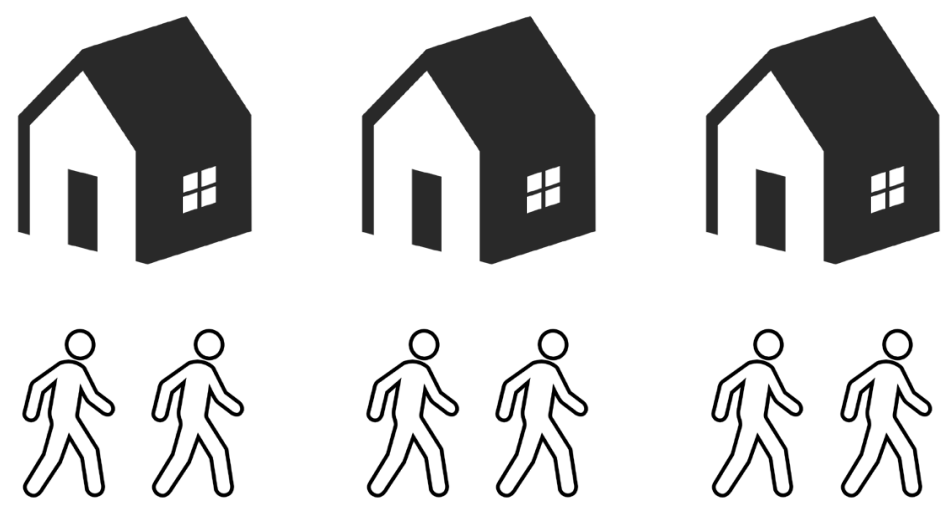

Diagram illustrating the increasing demand lower average household sizes have on housing requirements. 


\section{$\mathbb{M I I N I M U M I}$ FLOOR AREA TABLE}

Minimum gross internal floor area information was sourced by the Department for Communities and Local Government. Information was configured into a format that relates internal space to the number of bedrooms available for a dwelling. This provided quantitative classification for assessment purposes; information from the table was used to size smaller dwellings and test how urban consolidation can be achieved on the existing site. This is explored in the following pages.

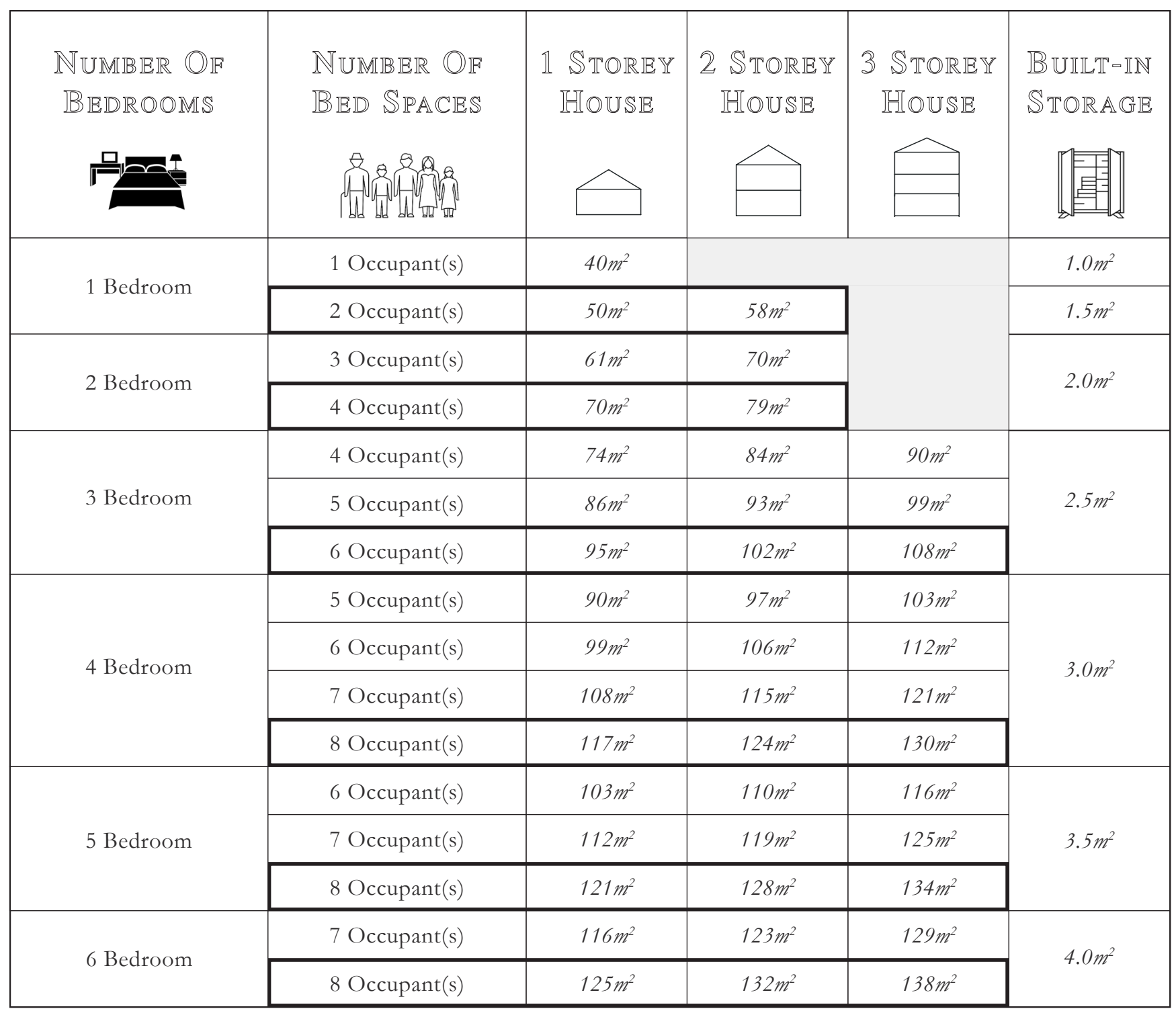


KEY FIGURES from density calculations
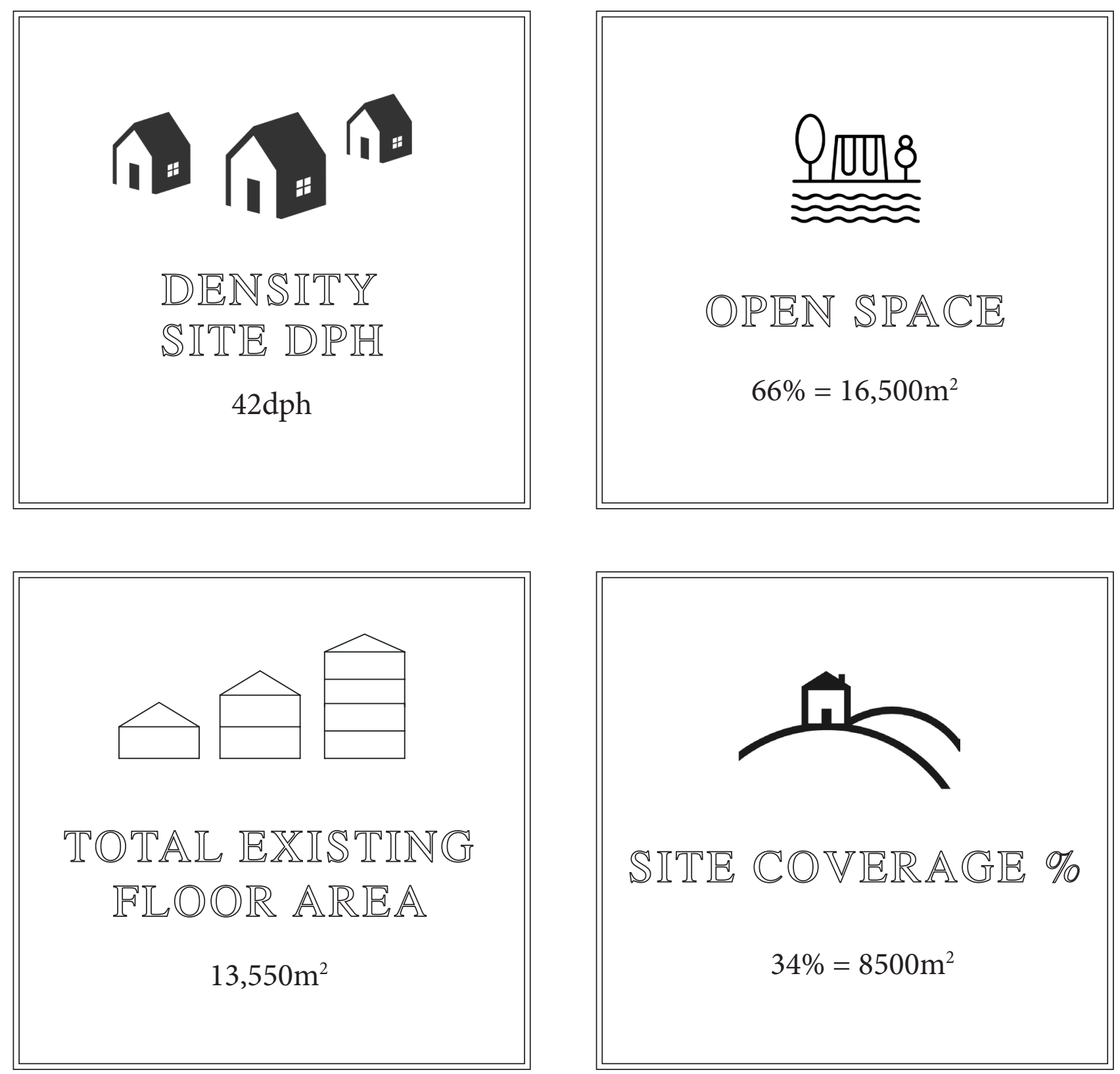


\section{E N S I T Y T E S T S}

Following pages demonstrate diagrammatic tests which investigated the effects an increase of built form has upon site coverage. Densification tests of $100 \%, 125 \%, 150 \%, 175 \%$ and $200 \%$ were conducted. A legend for the following process work is shown below.

\section{$\mathbb{L} \mathbb{E} G \mathbb{N} D$}

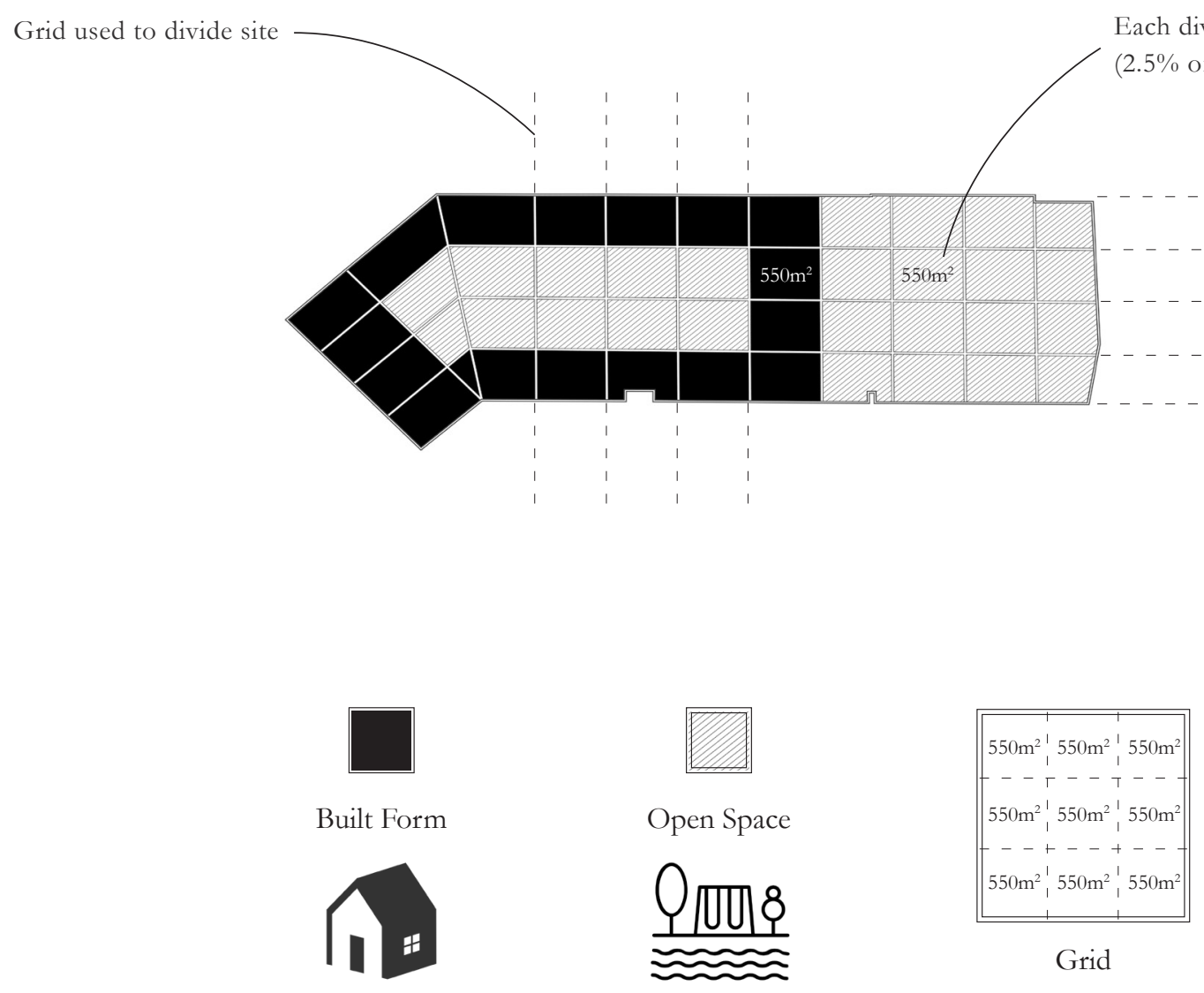



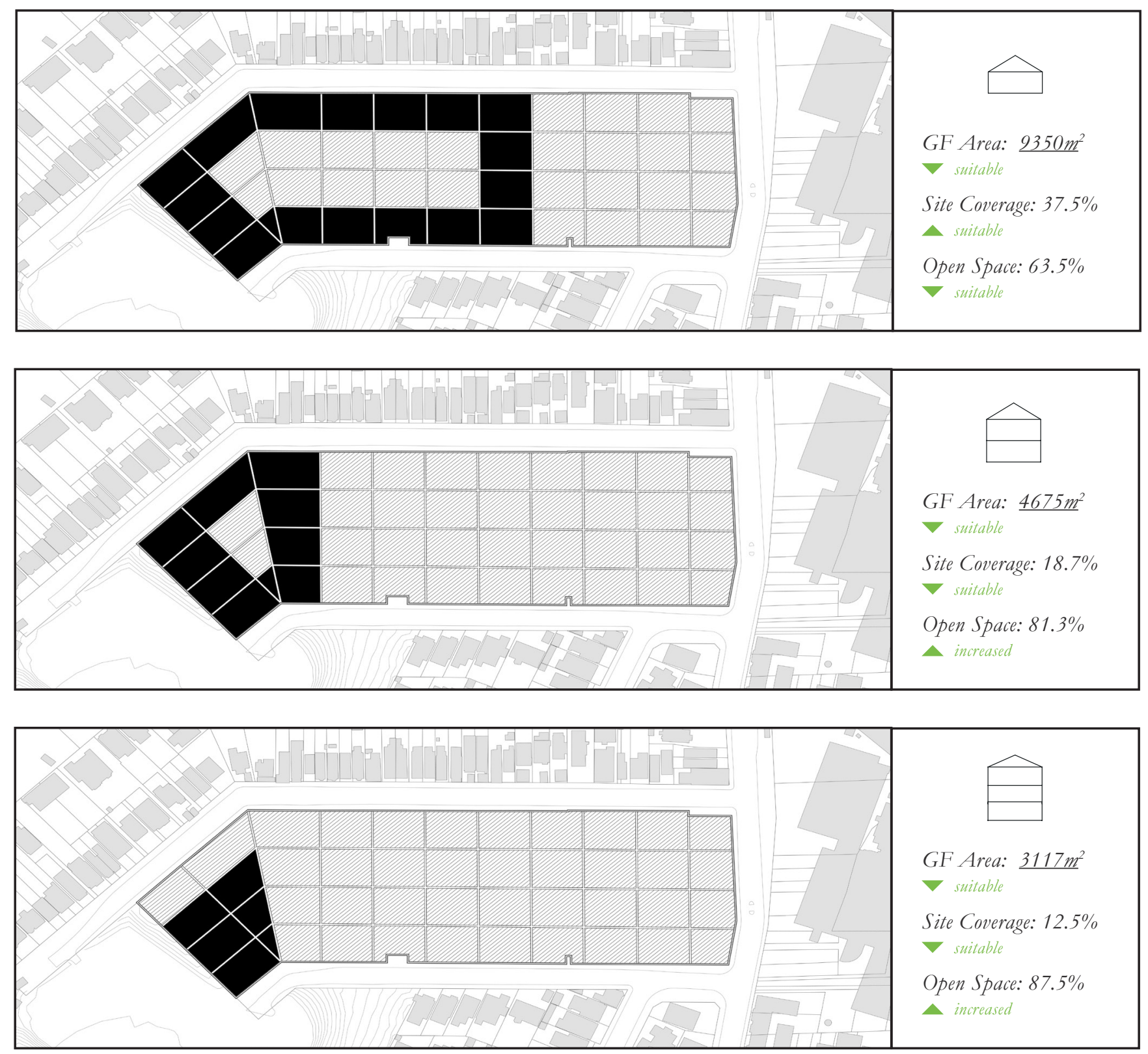

\begin{tabular}{|c|c|c|c|c|}
\hline $100 \%$ & $\begin{array}{c}\mathbb{D W E} \mathbb{L} \mathbb{I N G} \\
\mathbb{S} \mathbb{I Z E}\end{array}$ & $\begin{array}{l}\mathbb{N} U \mathbb{M B E R} \mathbb{O}_{\mathbb{F}} \\
\mathbb{D} \mathbb{E} \mathbb{L I I N G S}\end{array}$ & $\begin{array}{c}\mathbb{E} \mathbb{L} O \mathbb{R} \\
\mathbb{A} \mathbb{R} \mathbb{A}\end{array}$ & $\begin{array}{l}\text { Combined Footprint; } \\
\text { Area Coverage }\end{array}$ \\
\hline \multirow{5}{*}{$\begin{array}{c}100 \text { Dwellings } \\
(42 \mathrm{dph})\end{array}$} & $1 \operatorname{Bed}\left(50 \mathrm{~m}^{2}\right)$ & 5 & $250 \mathrm{~m}^{2}$ & $9330 \mathrm{~m}^{-}$ \\
\hline & $2 \operatorname{Bed}\left(70 \mathrm{~m}^{2}\right)$ & 20 & $1400 \mathrm{~m}^{2}$ & $4675 \mathrm{~m}^{2}$ \\
\hline & $3 \operatorname{Bed}\left(95 m^{2}\right)$ & 50 & $4500 \mathrm{~m}^{2}$ & \\
\hline & $4 \operatorname{Bed}\left(125 m^{2}\right)$ & 20 & $2500 \mathrm{~m}^{2}$ & $: 3117 m^{2}$ \\
\hline & $5 \operatorname{Bed}\left(140 m^{2}\right)$ & 5 & $700 m^{2}$ & \\
\hline
\end{tabular}



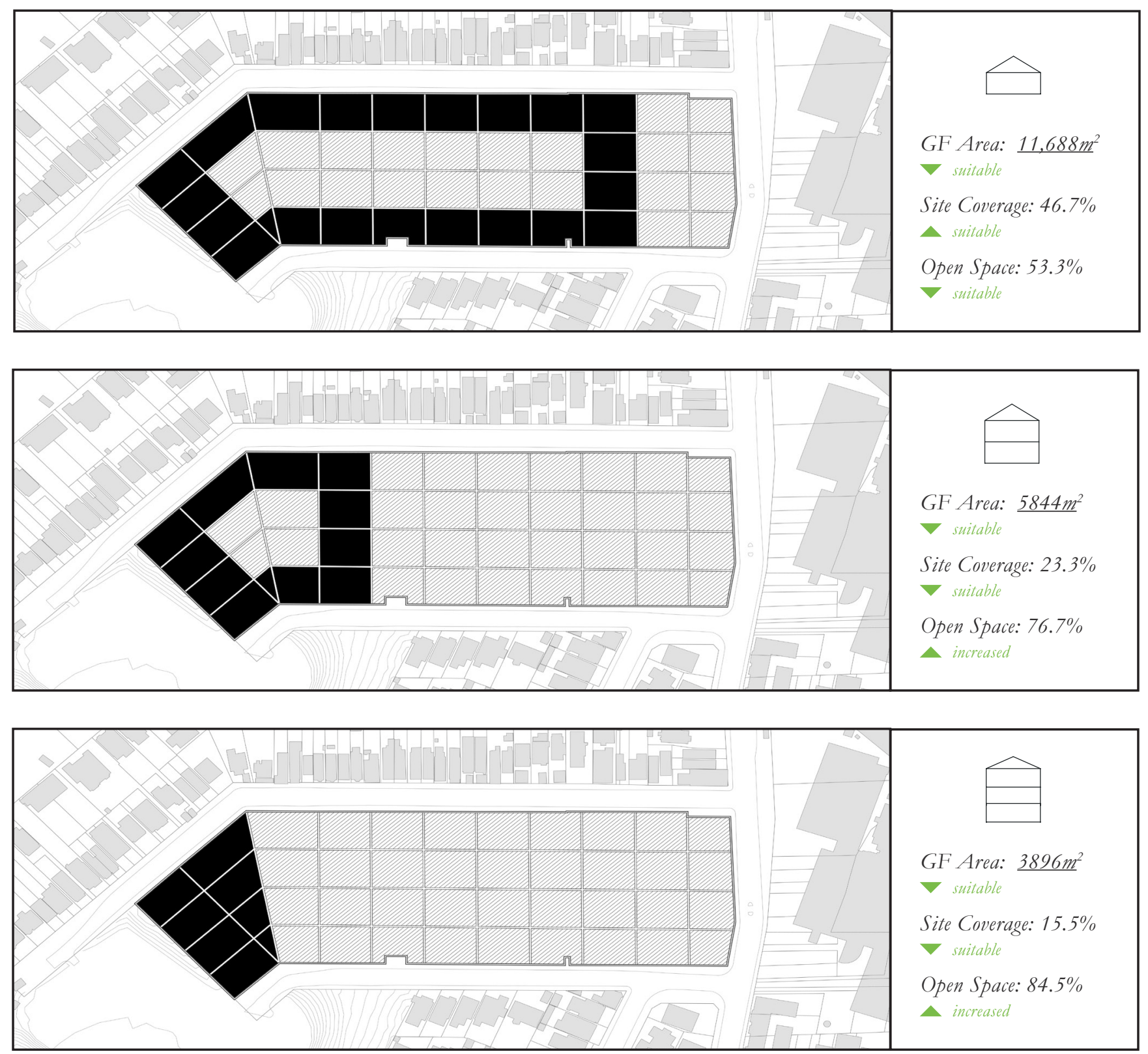

\begin{tabular}{|c|c|c|c|c|}
\hline $125 \%$ & $\begin{array}{c}\mathbb{D W} \mathbb{E} \mathbb{L} \mathbb{N} \mathbb{G} \\
\mathbb{S} I \mathbb{Z} \mathbb{E}\end{array}$ & $\begin{array}{l}\mathbb{N} U \mathbb{M B} \mathbb{E} \mathbb{R} \mathbb{O}^{\mathbb{F}} \\
\mathbb{D W} \mathbb{E} L I \mathbb{N} G S\end{array}$ & $\begin{array}{c}\mathbb{F} L O O \mathbb{R} \\
\mathbb{A} \mathbb{R} \mathbb{A}\end{array}$ & $\begin{array}{l}\text { Combined Footprint; } \\
\text { Site Coverage }\end{array}$ \\
\hline \multirow{5}{*}{$\begin{array}{c}125 \text { Dwellings } \\
(52 \mathrm{dph})\end{array}$} & $1 \operatorname{Bed}\left(50 m^{2}\right)$ & 6 & $310 \mathrm{~m}^{2}$ & \multirow{5}{*}{$\begin{array}{l}\square: \underline{5844 \mathrm{~m}^{2}} \\
\square: 3896 \mathrm{~m}^{2}\end{array}$} \\
\hline & $2 \operatorname{Bed}\left(70 \mathrm{~m}^{2}\right)$ & 25 & $1750 \mathrm{~m}^{2}$ & \\
\hline & $3 \operatorname{Bed}\left(95 m^{2}\right)$ & 63 & $5625 \mathrm{~m}^{2}$ & \\
\hline & $4 \operatorname{Bed}\left(125 m^{2}\right)$ & 25 & $3125 \mathrm{~m}^{2}$ & \\
\hline & $5 \operatorname{Bed}\left(140 m^{2}\right)$ & 6 & $875 m^{2}$ & \\
\hline
\end{tabular}



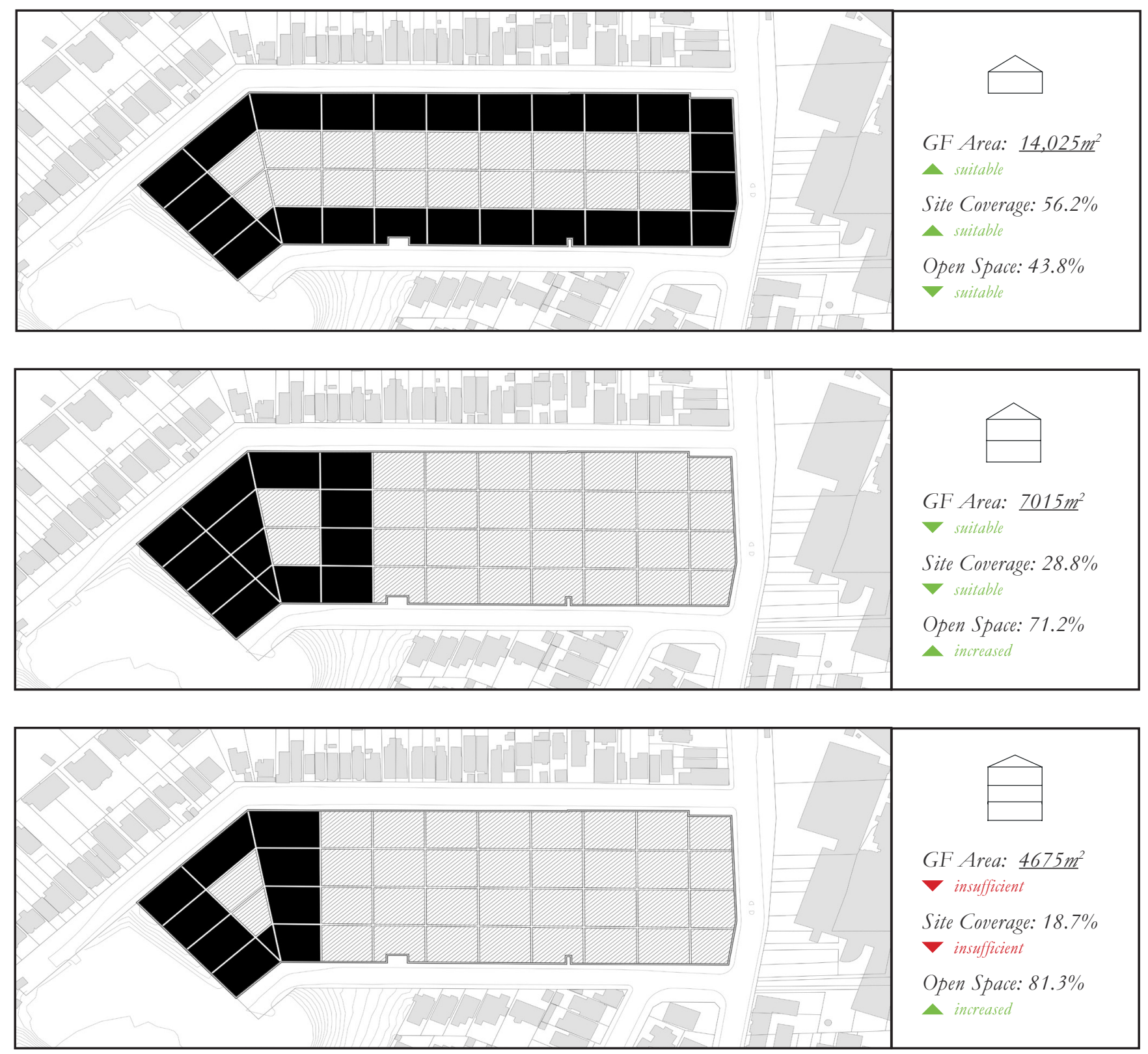

\begin{tabular}{|c|c|c|c|c|}
\hline $150 \%$ & $\begin{array}{c}\mathbb{D W \mathbb { E }} \mathbb{L} \mathbb{N} G \\
\mathbb{S} \mathbb{I} \mathbb{E}\end{array}$ & $\begin{array}{l}\mathbb{N} U \mathbb{M B} \mathbb{E} \mathbb{R} \\
\mathbb{D} \mathbb{E} \mathbb{E} L \mathbb{I N G S}\end{array}$ & $\begin{array}{c}\mathbb{F} L O O \mathbb{R} \\
\mathbb{A} \mathbb{R} \mathbb{A}\end{array}$ & \multirow{6}{*}{$\begin{array}{l}\text { Combined Footprint; } \\
\text { Area Coverage } \\
: \underline{14,025 \mathrm{~m}^{2}}\end{array}$} \\
\hline \multirow{5}{*}{$\begin{array}{c}150 \text { Dwellings } \\
(63 \mathrm{dph})\end{array}$} & $1 \operatorname{Bed}\left(50 m^{2}\right)$ & 8 & $375 m^{2}$ & \\
\hline & $2 \operatorname{Bed}\left(70 \mathrm{~m}^{2}\right)$ & 30 & $2100 \mathrm{~m}^{2}$ & \\
\hline & $3 \operatorname{Bed}\left(95 m^{2}\right)$ & 75 & $6750 \mathrm{~m}^{2}$ & \\
\hline & $4 \operatorname{Bed}\left(125 m^{2}\right)$ & 30 & $3750 \mathrm{~m}^{2}$ & \\
\hline & $5 \operatorname{Bed}\left(140 m^{2}\right)$ & 8 & $1050 \mathrm{~m}^{2}$ & \\
\hline
\end{tabular}



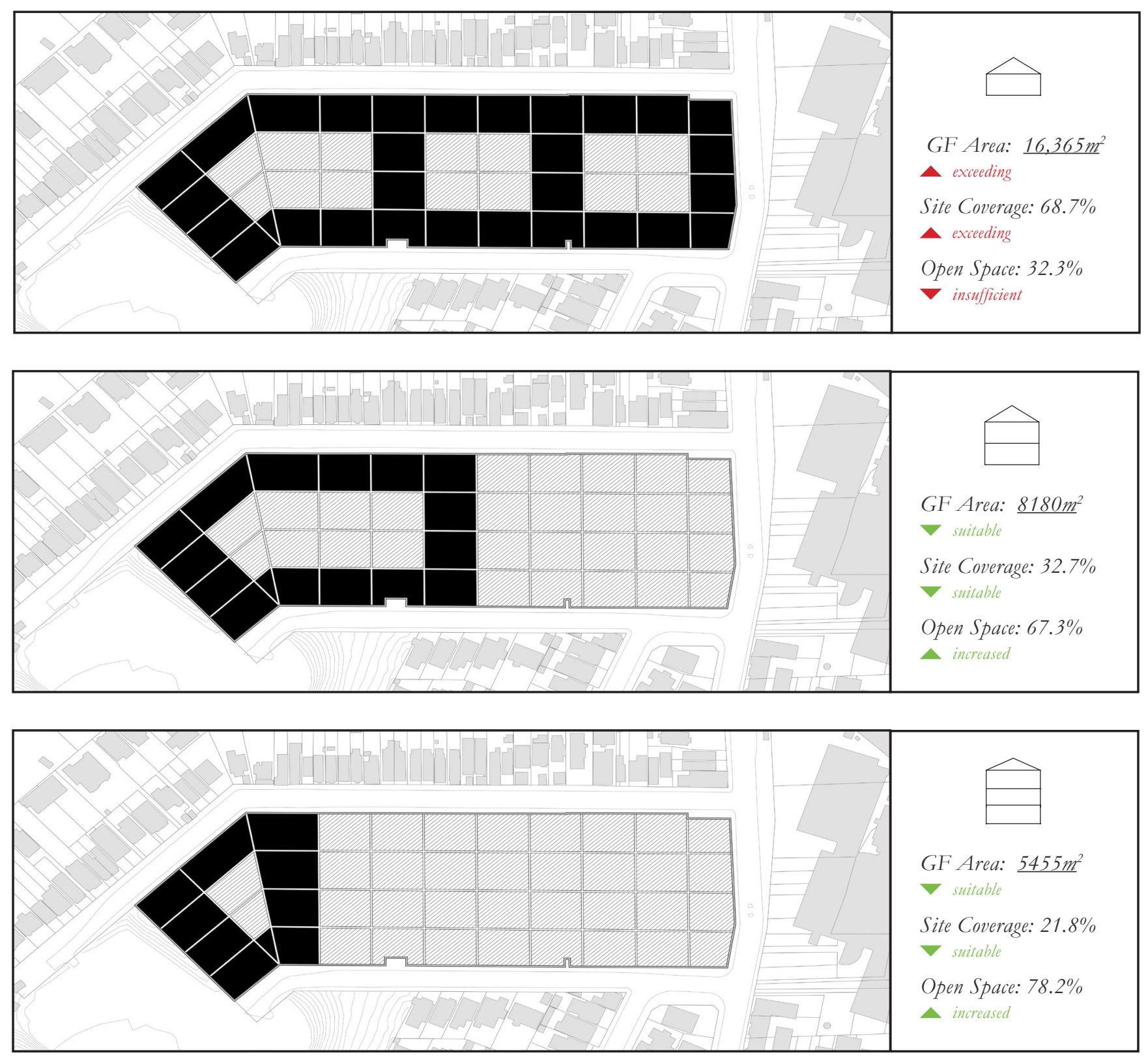

\begin{tabular}{|c|c|c|c|c|}
\hline $175 \%$ & 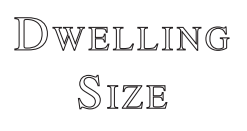 & $\begin{array}{l}\mathbb{N} U \mathbb{M} B \mathbb{R} \mathbb{R} \\
\mathbb{D} W \mathbb{E} L \mathbb{I} \mathbb{N} G S\end{array}$ & $\begin{array}{l}\mathbb{F} L O O \mathbb{R} \\
\mathbb{A} \mathbb{R} \mathbb{A}\end{array}$ & \multirow{2}{*}{$\begin{array}{l}\text { Combined Footprint; } \\
\text { Area Coverage } \\
\qquad: \underline{16,365 \mathrm{~m}^{2}}\end{array}$} \\
\hline \multirow{5}{*}{$\begin{array}{c}175 \text { Dwellings } \\
(73 \mathrm{dph})\end{array}$} & $1 \operatorname{Bed}\left(50 m^{2}\right)$ & 9 & $440 m^{2}$ & \\
\hline & $2 \operatorname{Bed}\left(70 \mathrm{~m}^{2}\right)$ & 35 & $2450 \mathrm{~m}^{2}$ & \multirow{2}{*}{$\underline{8180 \mathrm{~m}^{2}}$} \\
\hline & $3 \operatorname{Bed}\left(95 m^{2}\right)$ & 88 & $7875 m^{2}$ & \\
\hline & $4 \operatorname{Bed}\left(125 m^{2}\right)$ & 35 & $4375 m^{2}$ & \multirow[t]{2}{*}{$\underline{5455 m^{2}}$} \\
\hline & $5 \operatorname{Bed}\left(140 \mathrm{~m}^{2}\right)$ & 9 & $1225 m^{2}$ & \\
\hline
\end{tabular}



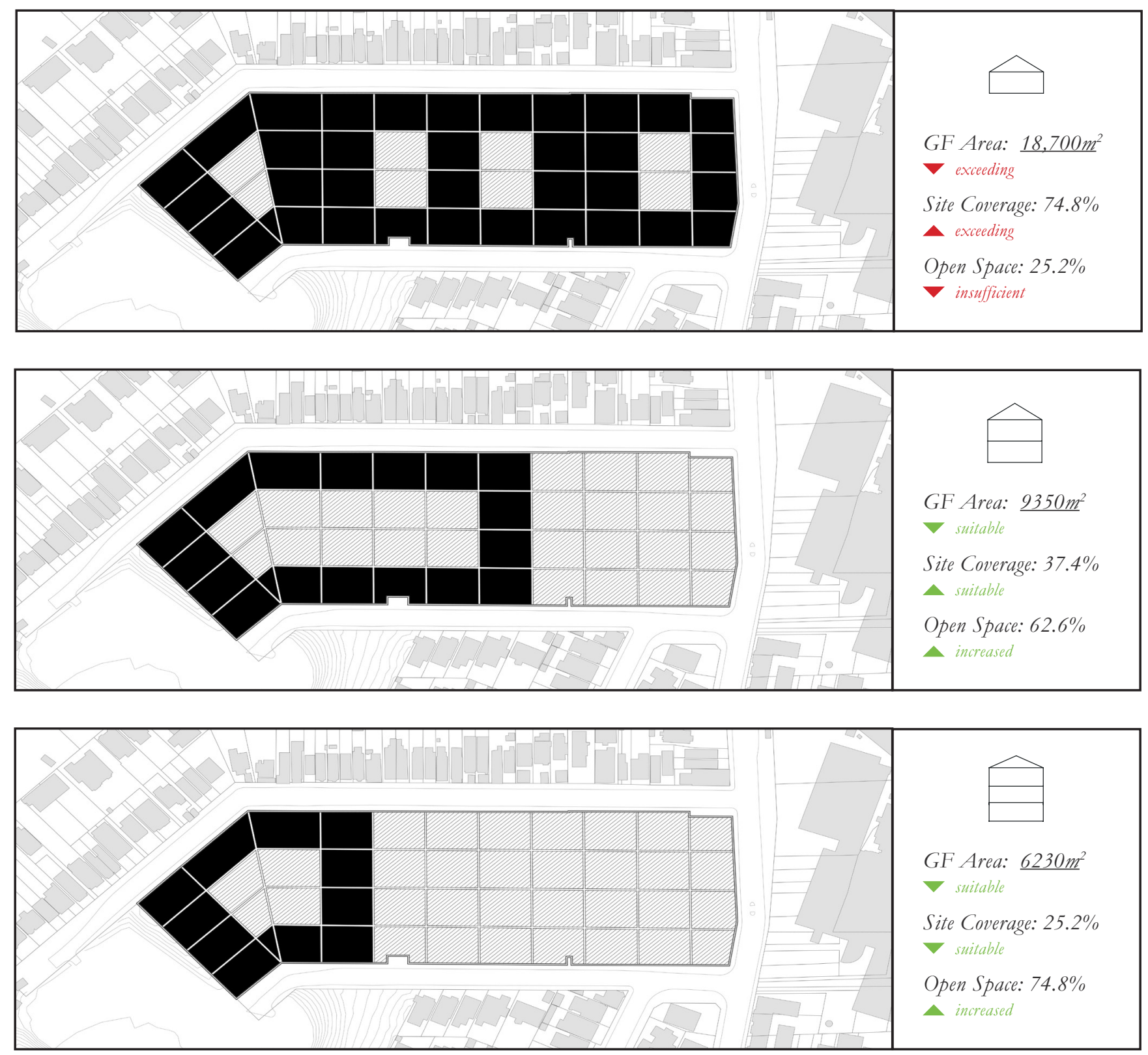

\begin{tabular}{|c|c|c|c|c|}
\hline $200 \%$ & $\begin{array}{c}\text { DWELLING } \\
\mathbb{S} I \mathbb{Z} \mathbb{E}\end{array}$ & $\begin{array}{l}\mathbb{N} U \mathbb{M B} \mathbb{E} \mathbb{R} \mathbb{F} \\
\mathbb{D} W \mathbb{E} L I \mathbb{N} G S\end{array}$ & $\begin{array}{c}\mathbb{E} \mathbb{L O O R} \\
\mathbb{A} \mathbb{R} \mathbb{E}\end{array}$ & $\begin{array}{l}\text { Combined Footprint; } \\
\text { Area Coverage } \\
: 18,700 \mathrm{~m}\end{array}$ \\
\hline \multirow{5}{*}{$\begin{array}{c}200 \text { Dwellings } \\
(83 \mathrm{dph})\end{array}$} & $1 \operatorname{Bed}\left(50 \mathrm{~m}^{2}\right)$ & 10 & $500 \mathrm{~m}^{2}$ & \multirow{5}{*}{$: \underline{9350 \mathrm{~m}^{2}}$} \\
\hline & $2 \operatorname{Bed}\left(70 \mathrm{~m}^{2}\right)$ & 40 & $2800 \mathrm{~m}^{2}$ & \\
\hline & $3 \operatorname{Bed}\left(95 \mathrm{~m}^{2}\right)$ & 100 & $9000 \mathrm{~m}^{2}$ & \\
\hline & $4 \operatorname{Bed}\left(125 m^{2}\right)$ & 40 & $5000 \mathrm{~m}^{2}$ & \\
\hline & $5 \operatorname{Bed}\left(140 m^{2}\right)$ & 10 & $1400 \mathrm{~m}^{2}$ & \\
\hline
\end{tabular}




\title{
DENSITY ANALYSIS REFLECTION
}

\author{
I N S UMMARY
}

Analysis of the Rolleston Street site gathered quantitative information to inform decisions of urban consolidation. Diagrammatic tests investigated what effects the increase of built form has upon site coverage. This assisted in suggesting suitable urban consolidation goals for the site.

The existing site contains 100 dwellings, measuring 42dph. To introduce more dwellings with suitable public space a densification of $175 \%$ dwellings was tested and determined as a functional increase. This percentage increase will allow for a balance to be retained between built form and landscape components, both required to achieve beneficial consolidation goals.

A consolidation goal to increase the site density by 175\% results in providing 175 dwellings at $73 \mathrm{dph}$. Creating smaller sized, attached dwellings in closer vicinity to one another attained initial densification in this section. This will be developed upon in later research and design process.

Continuing from the density investigation is a series of brief design tests conducted to provide alternative concepts for locating the higher density built form. These are included on the two following pages to develop upon the density reflection. 


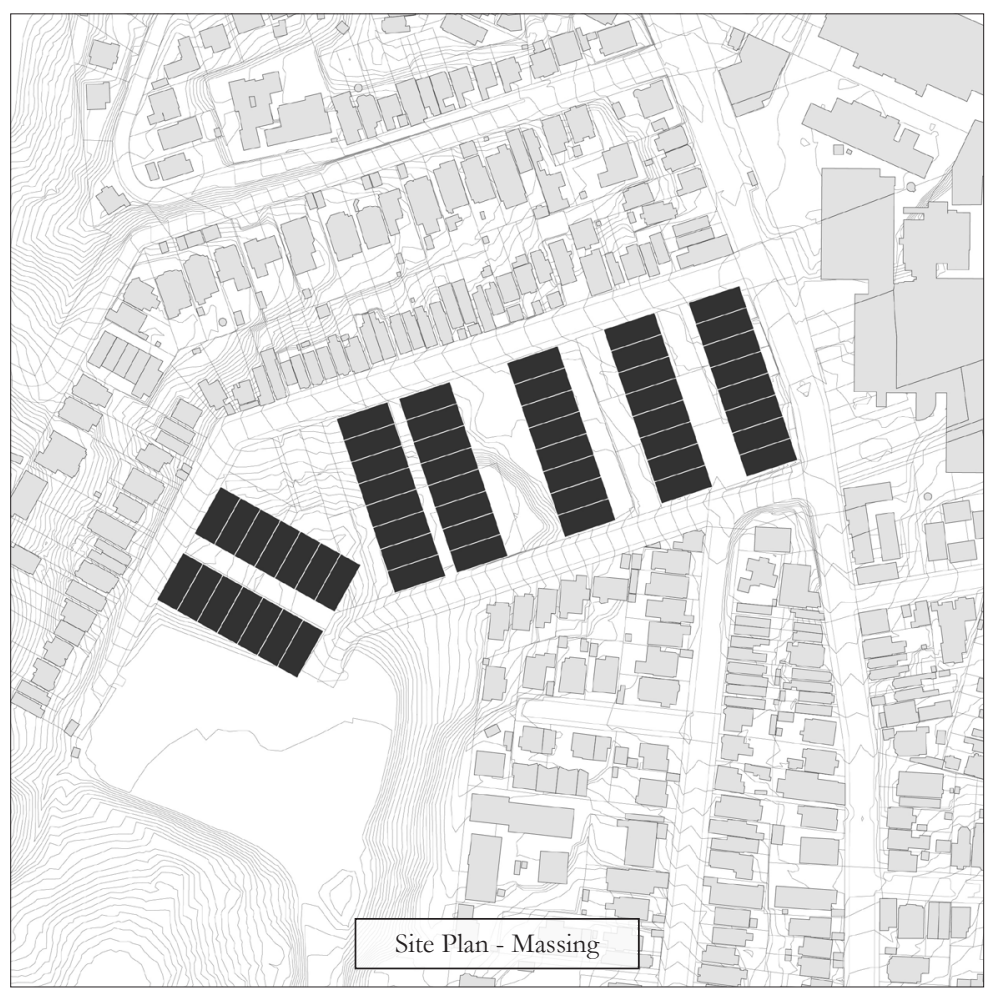

$\mathbb{A T T A C H E D ~ R O W ~ A L O N G ~}$

Arranging repetitive attached rows along contours opens up lateral street connections and allows access roads to be easily integrated.
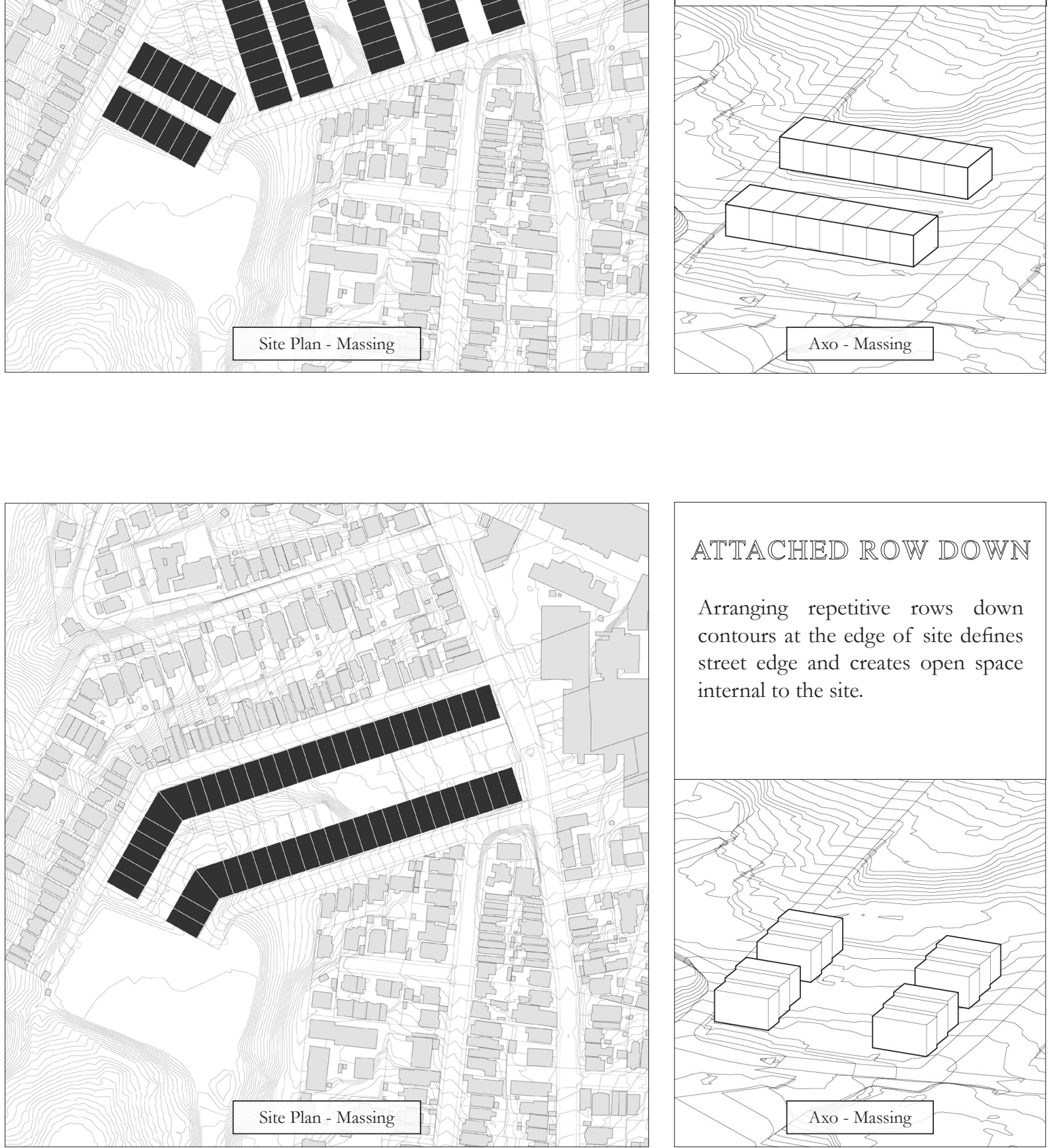

\section{ATTACHIED ROW DOWN}

Arranging repetitive rows down contours at the edge of site defines street edge and creates open space internal to the site.

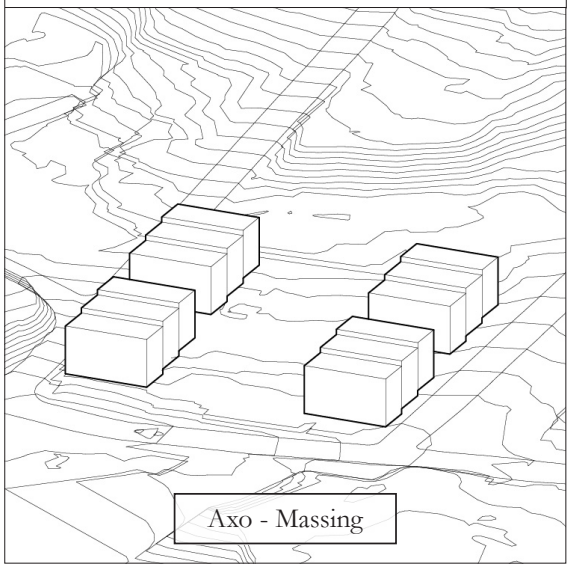


KNin

$\Delta$ 


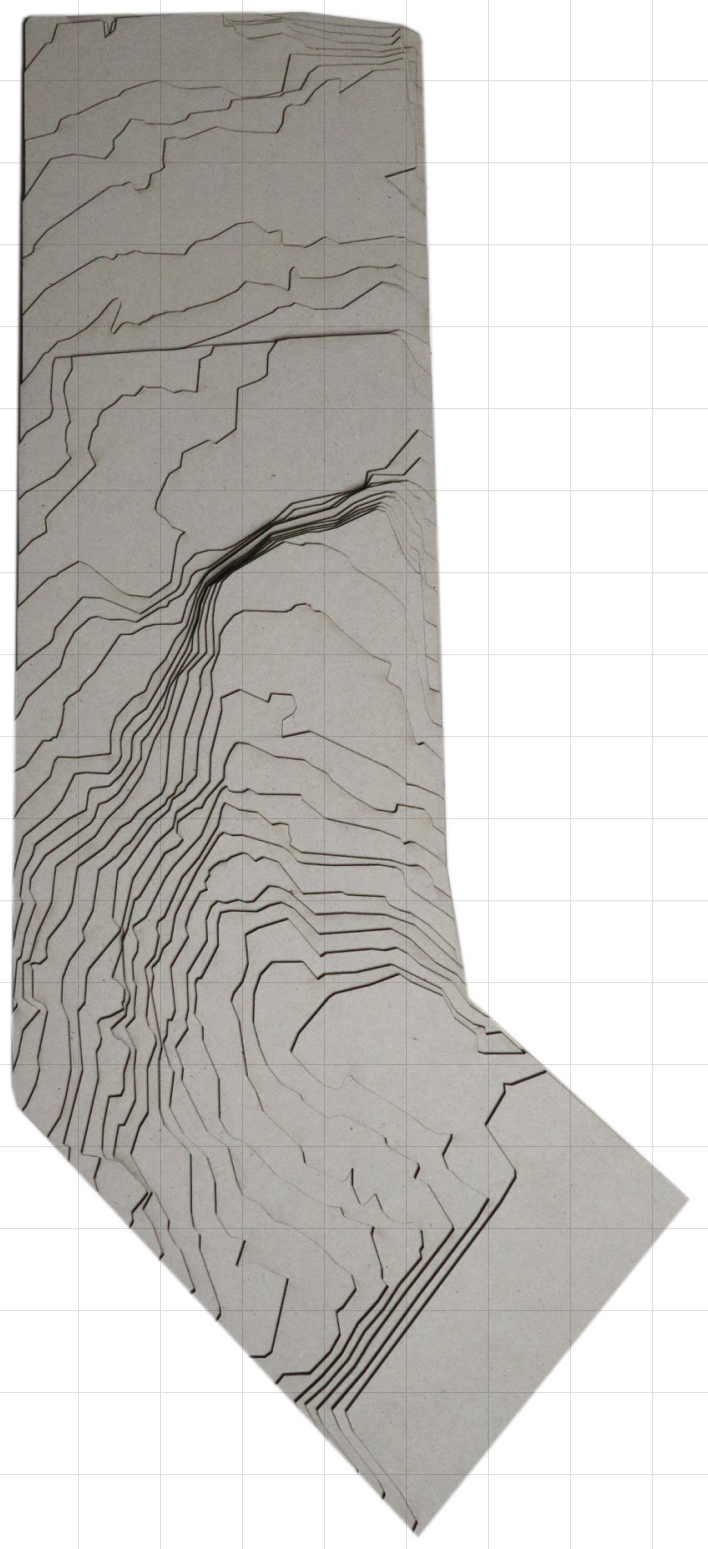

$\wedge$

Figure 50 // 1:500 model; site contours 


\section{TOPOGRAPHY ANALYSIS I}

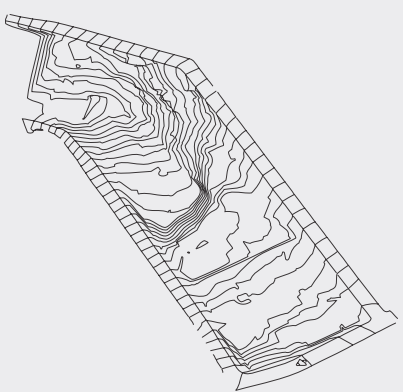

Chapter containins visual and written documentation of the design process, with critical reflection.

The following investigation into topography and applying built form is divided into two sections. The first section takes a closer look at identifying gradients to classify slopes and landforms. The second section tests the fit of built form against the various types of slopes.

The aim of this study is to understand what are the most appropriate areas on a site for densification and which typologies best align with the various slope gradients and landforms 


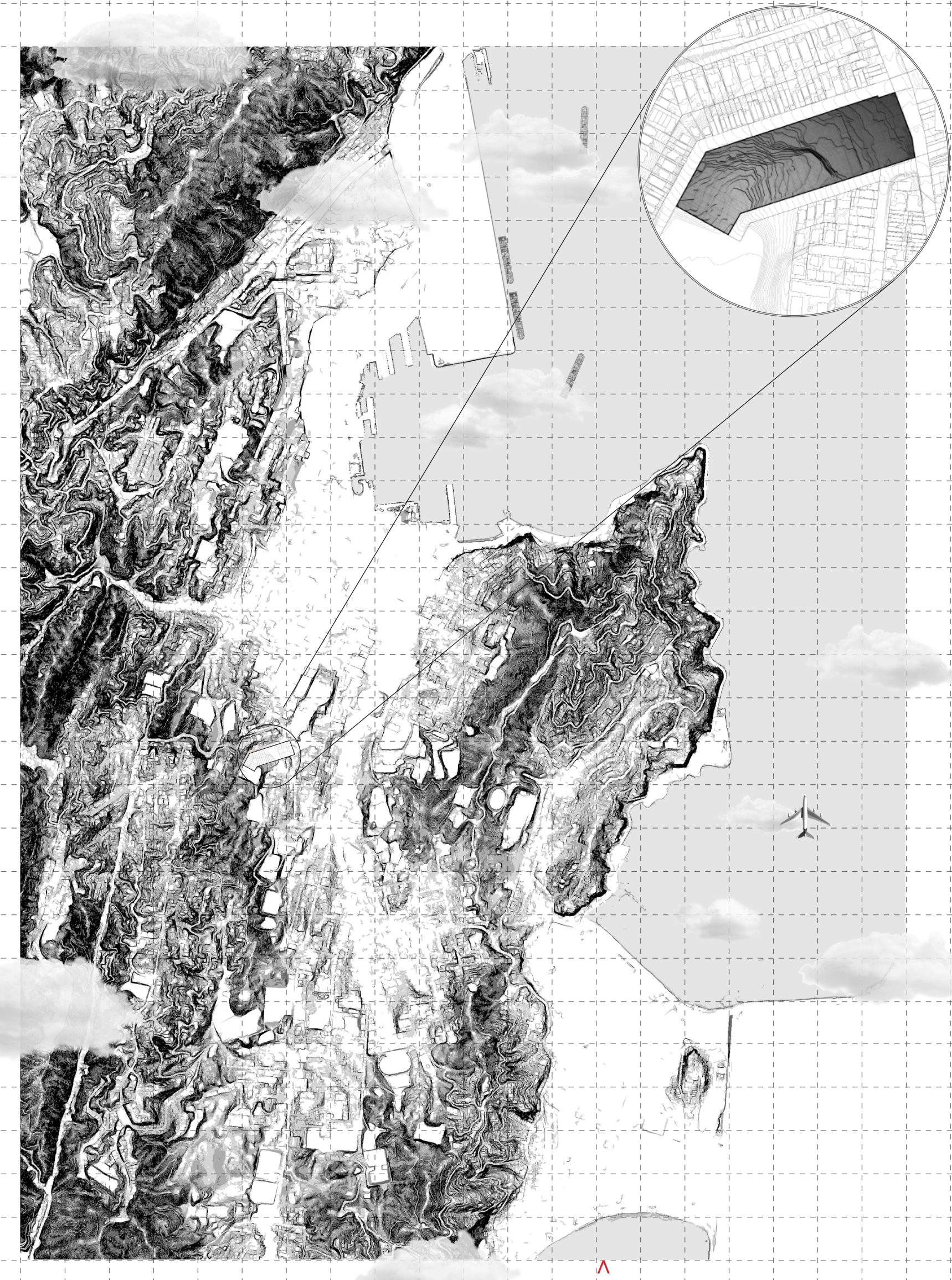

Figure 51 // Wellingtpn aerial; site_location in city 


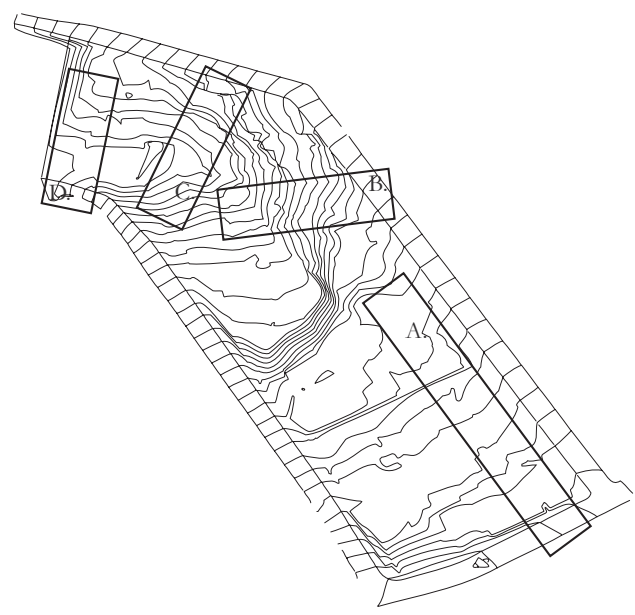

$\wedge$

Figure 52 // Diagram; locating section cuts

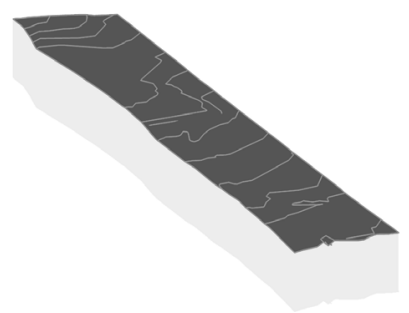

A.
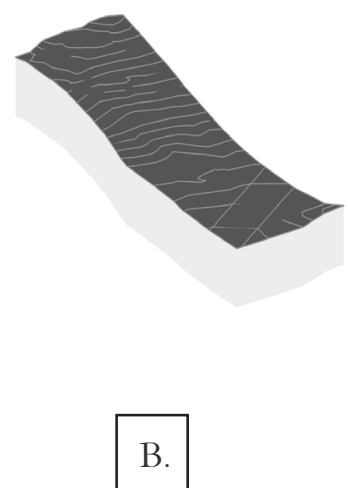

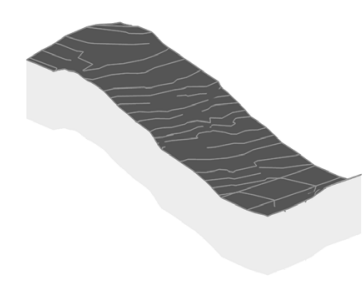

C.

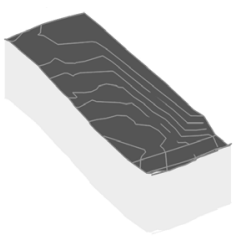

D.

$\Lambda$

Figure 53 // Iso Models; site slope sections

Iso Models of the site were taken through topography to discover variations in landform gradients and directionality of slopes. From analysis it was clear the site became divided into a top and bottom half with different topographical conditions. Steeper gradients were found towards the top of the site whereas shallower slopes were more common towards the lower half. Section model $A$ consists of a gentle incline compared to Section model $B, C$ and $D$ located higher on the site, sloping upwards and towards to the Wellington Town Belt. 


\section{S L O PE A N A LYS IS}

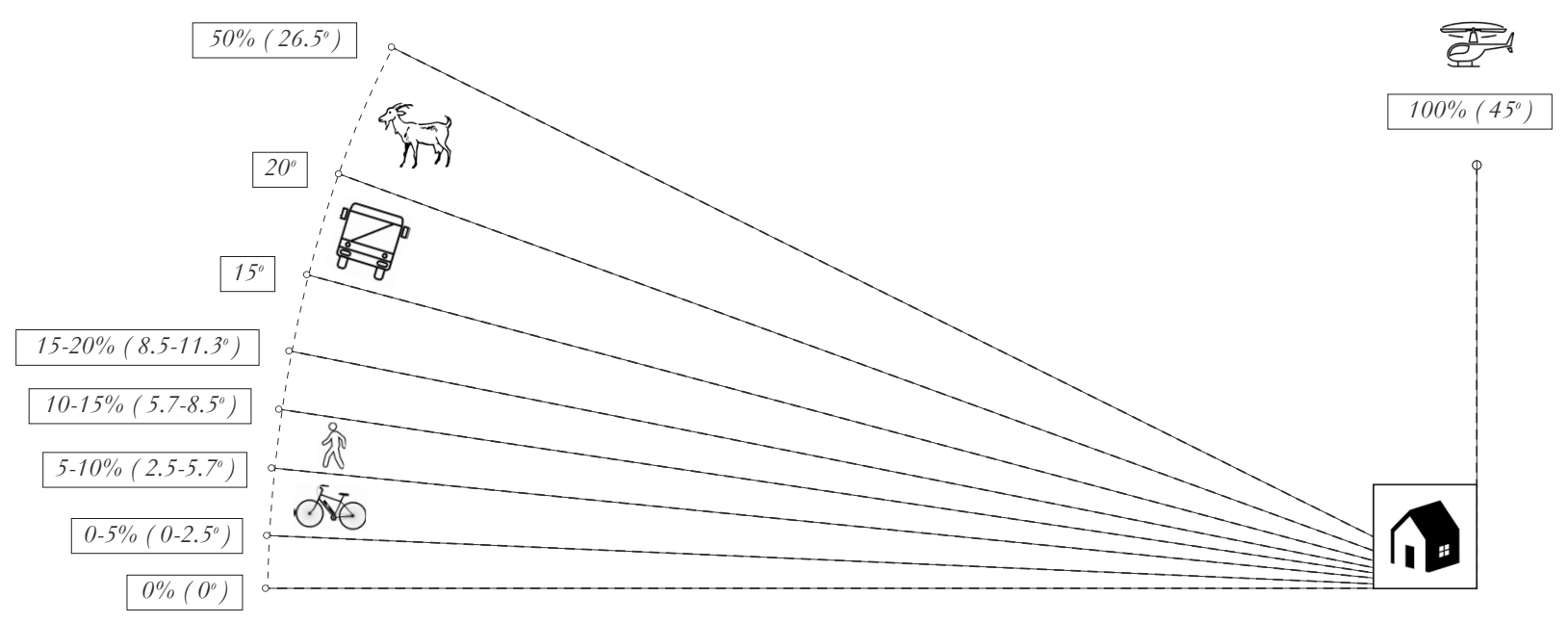

Slope Classification

$\begin{array}{cc}\text { Angle } & \text { Classification and Use } \\ 45^{\circ} & \text { Very Steep (repose: Rock embankment) } \\ 20^{\circ} & \text { Steep (max. slope: grade IV agricultural land) } \\ 10^{\circ} & \text { Strong (max. slope: general house building) } \\ 5^{\circ} & \text { Moderate ( } \max \text {. slope: pedestrian ramps, prams) } \\ 1^{\circ} & \text { Gentle (max. housing with special provisions) }\end{array}$

TOPOGRAPHY ANALYSIS

The topography analysis and slope maps provided evidence of a variety in slope gradients and landform on the Rolleston Street site. Classification of gradients are then used to structure research and design tests of applying built form to slopes in topography analysis section two. 

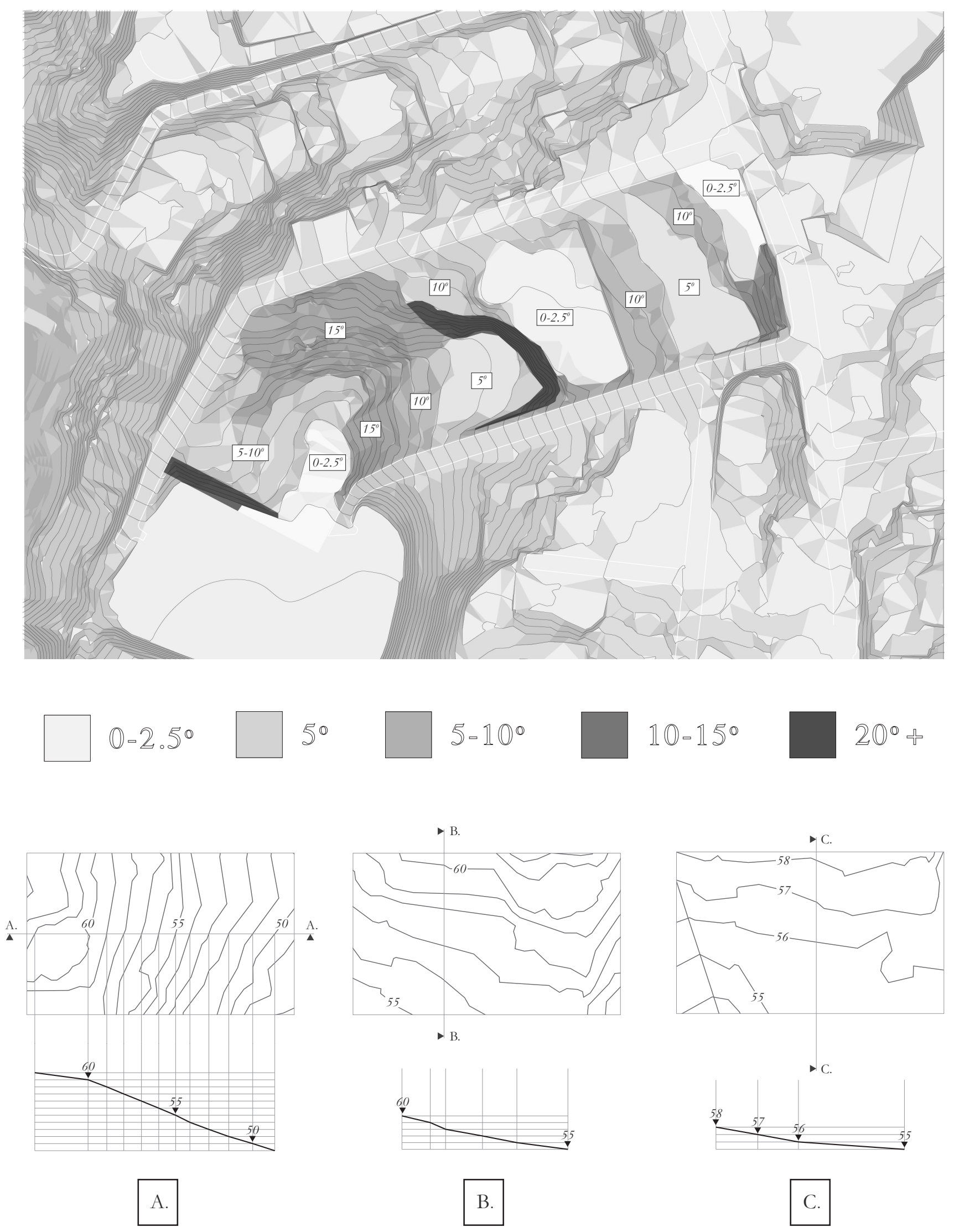


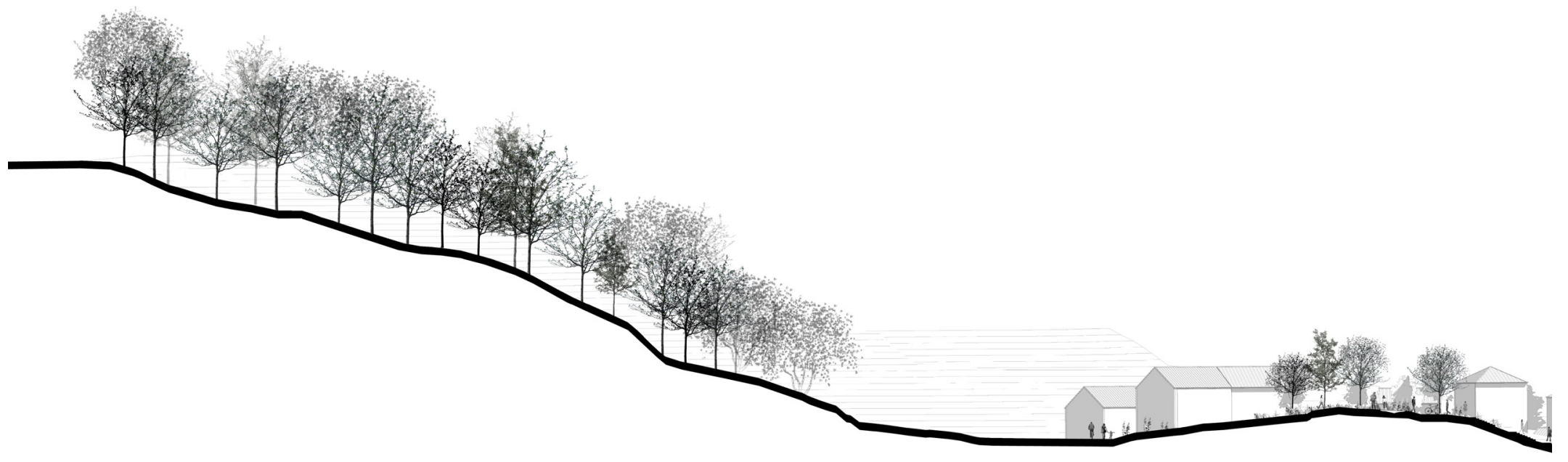




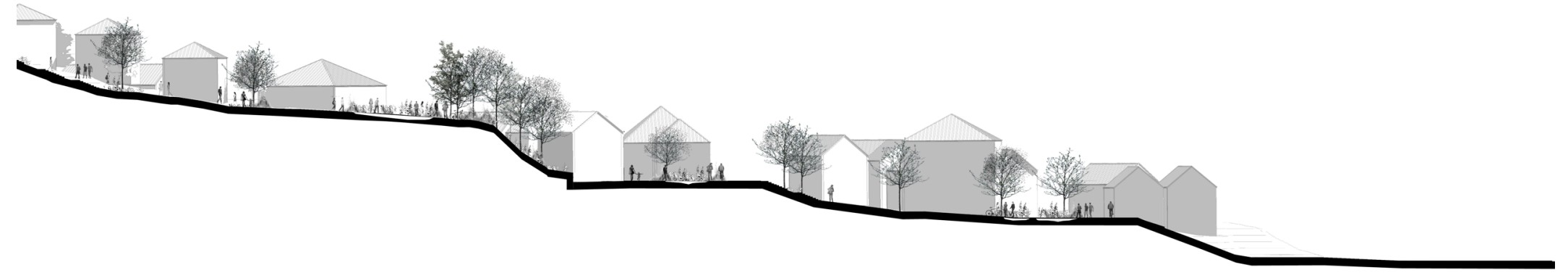




\title{
TOPOGRAPHY ANALYSIS II
}

\author{
A P PLYNG BUILT FORM TO SLOPES
}

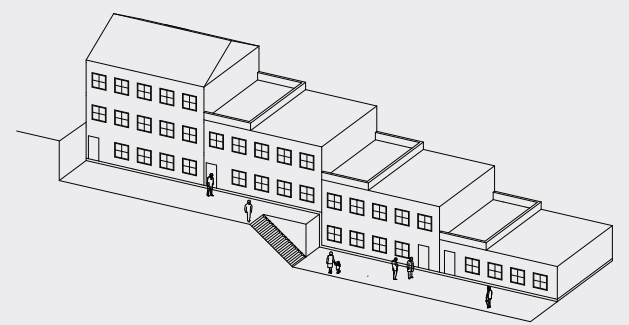

Topography Analysis II involves research and investigation into the application of built form onto slopes. The study includes research into existing terrace housing projects that are displayed on both flat and sloped topography.

The aim of this analysis was to uncover the relationship between building depths and heights relative to gradient and from this develop an inventory of housing typologies that are organised according to gradient. 

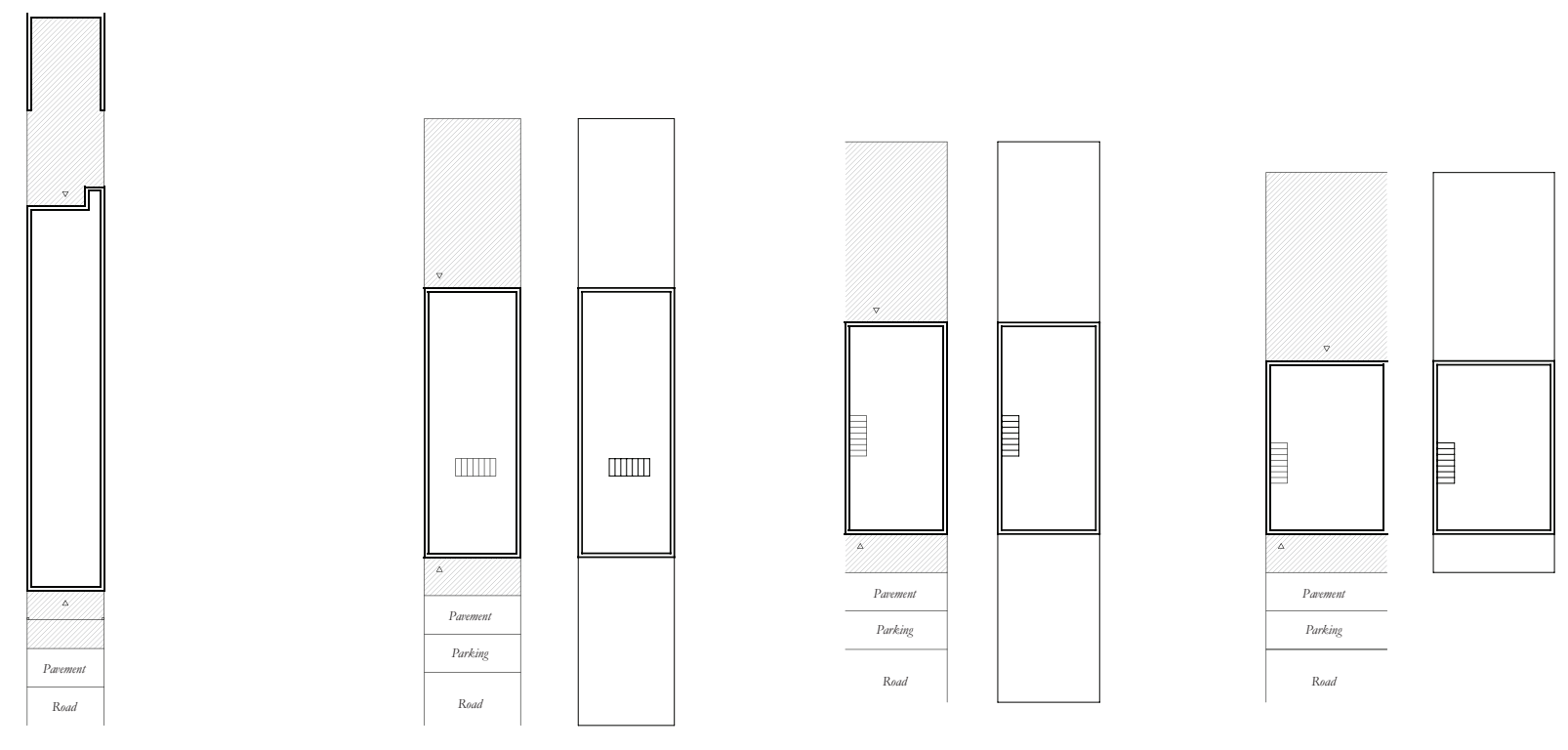

1

2

3

4
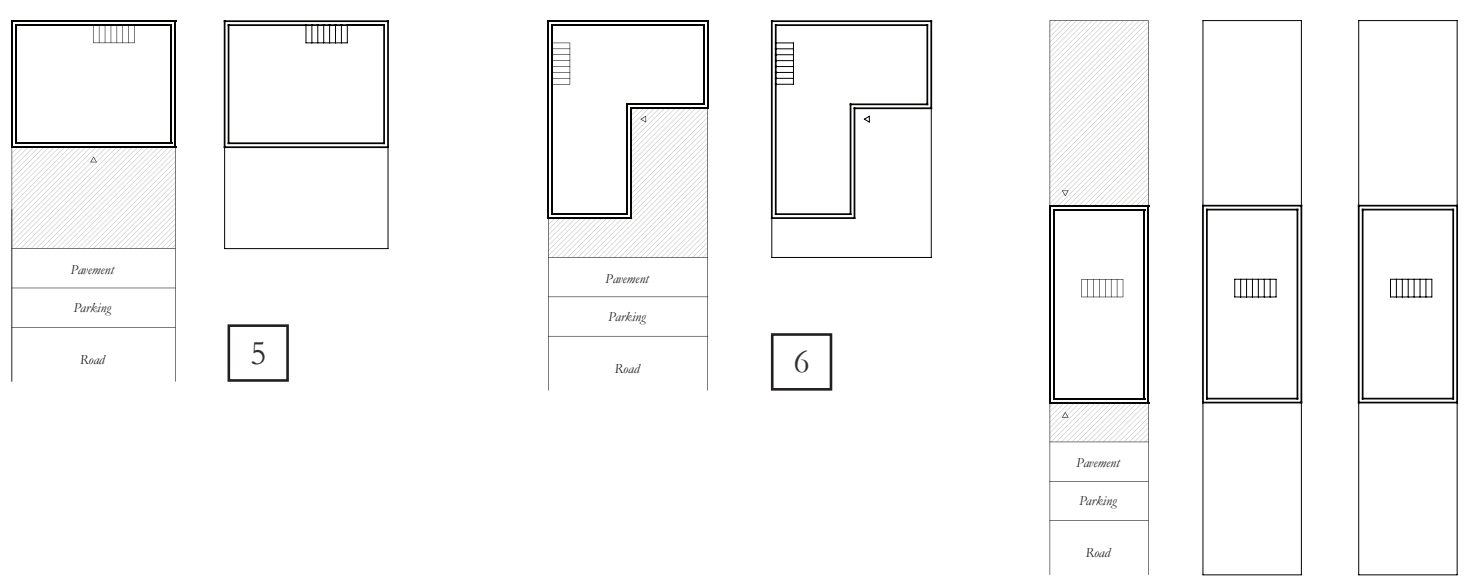

7
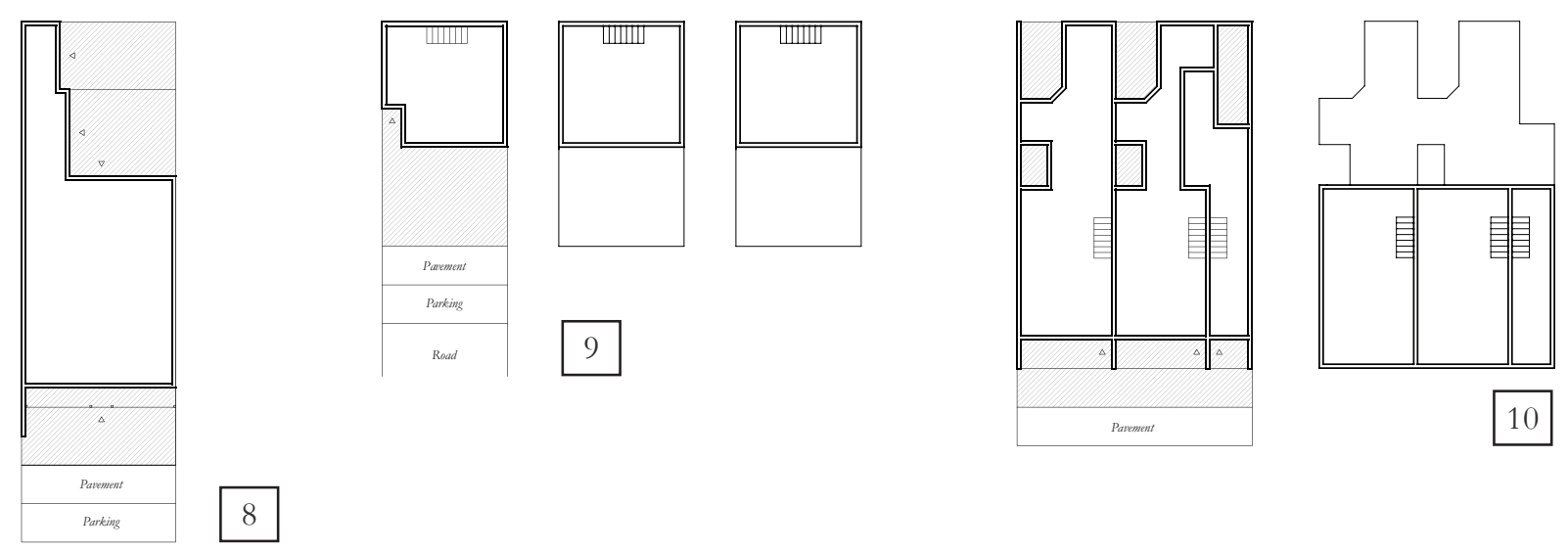

8 

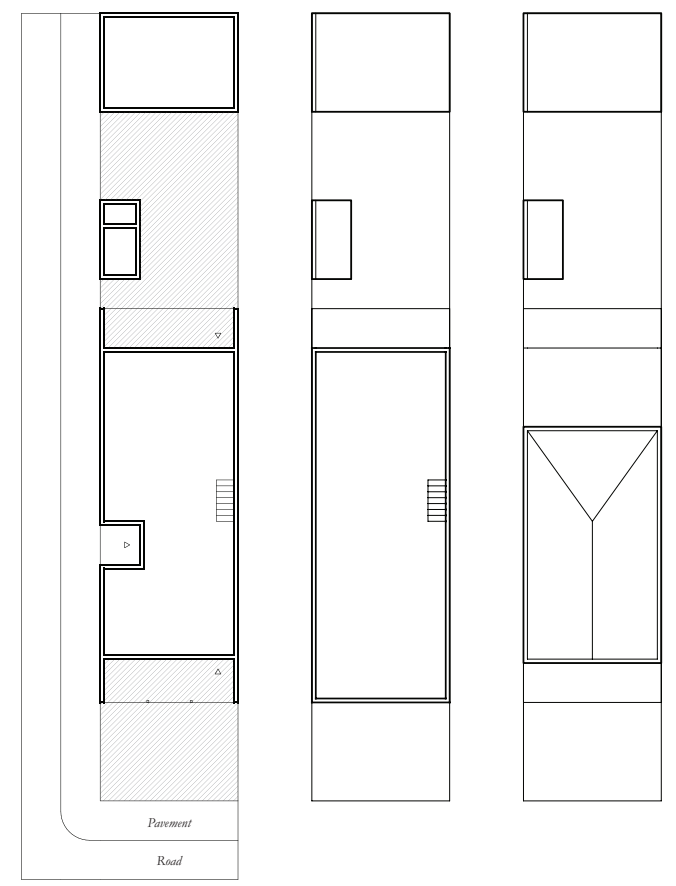

11
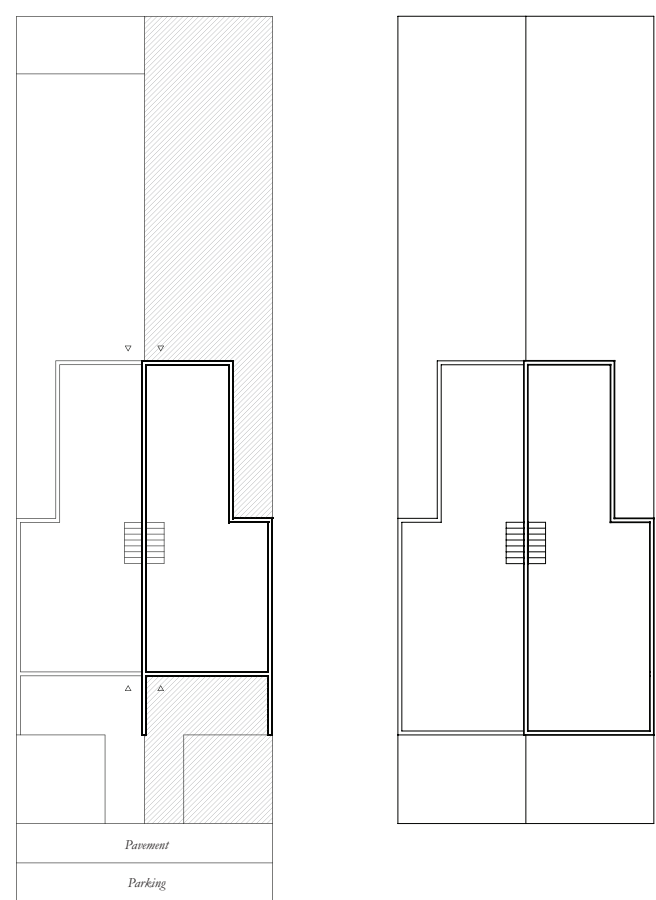

13
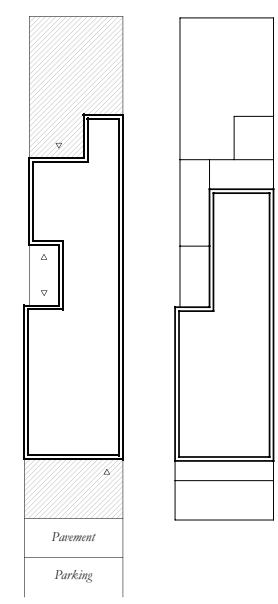

12

T E R R A C E I N V E N T O R Y

\section{FLAT SITE DWELLINGS}

An inventory of housing typologies organized according to gradient

1. Argyle Street Fitzroy

2. Design Handbook Type B

3. Design Handbook Type C

4. Design Handbook Type D

5. Design Handbook Type E

6. Design Handbook Type G

7. Design Handbook Type A

8. Park Street Abbotsford

9. Design Handbook Type F

10. Drummond Street Carlton

11. Michael Street Clifton Hill

12. Paddington Terrace

13. Grattan Street Carlton 


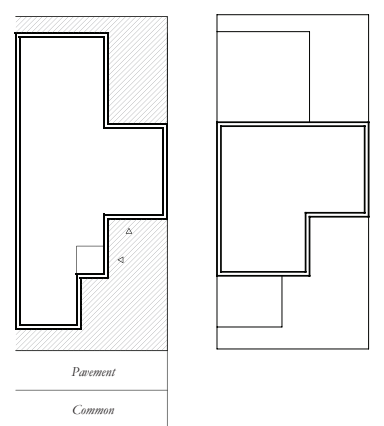

14
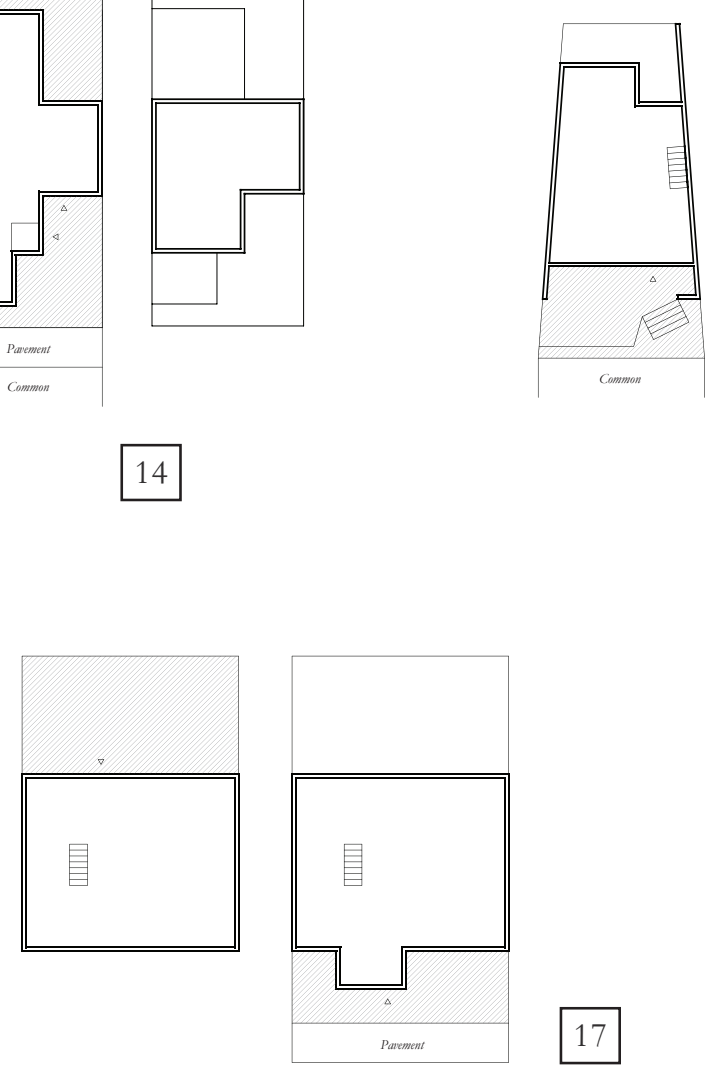

17

T ER R A C E I N V E N T O R Y

\section{SLOPED SITE DWELLINGS}

An inventory of housing typologies organized according to gradient

14. Duke Street

15. Beetham Cumbria

16. Langdon Hills

17. Peckarmans Wood

18. Siedlung Halen
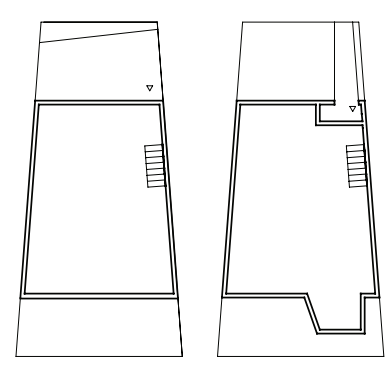

15
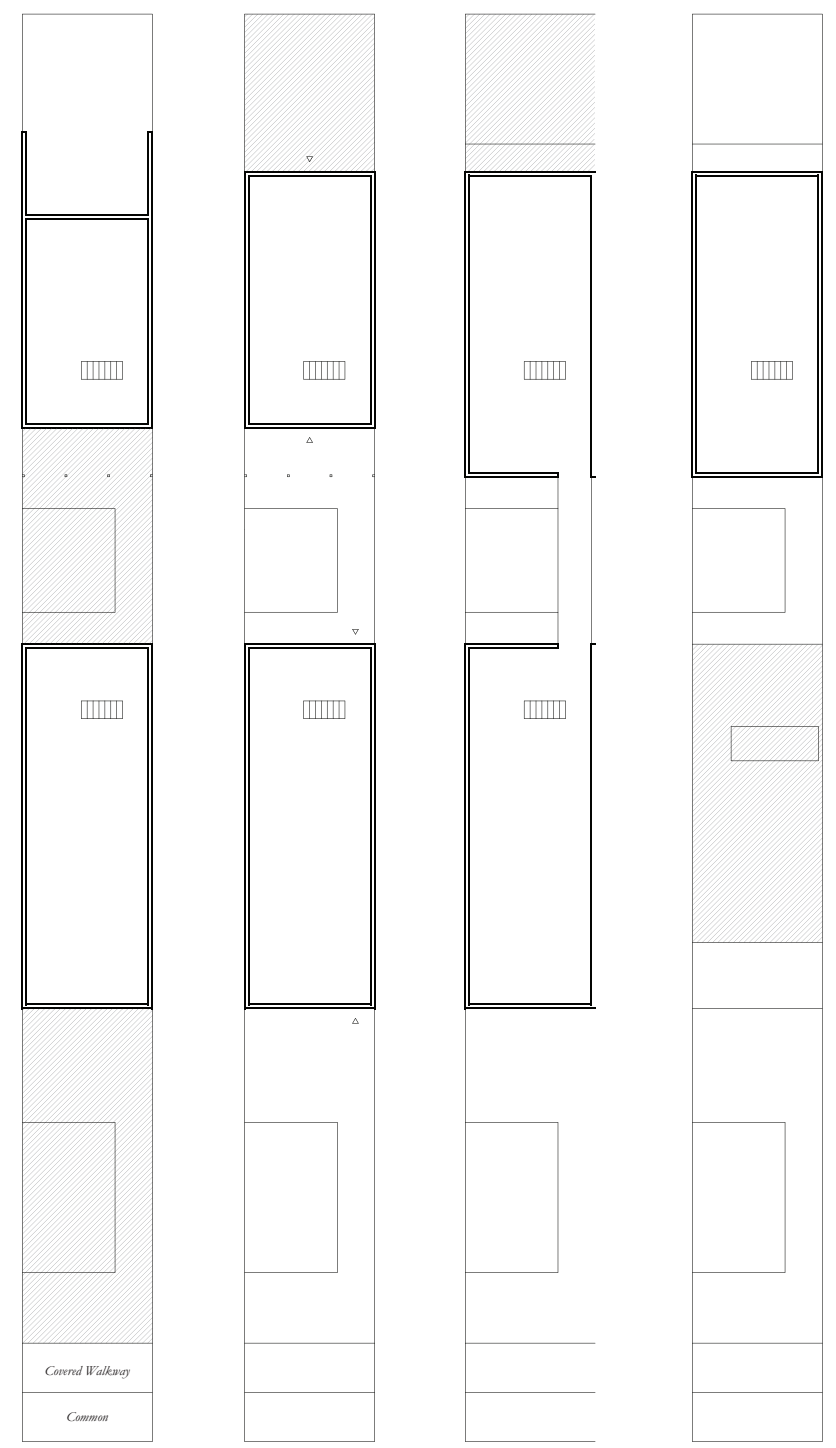

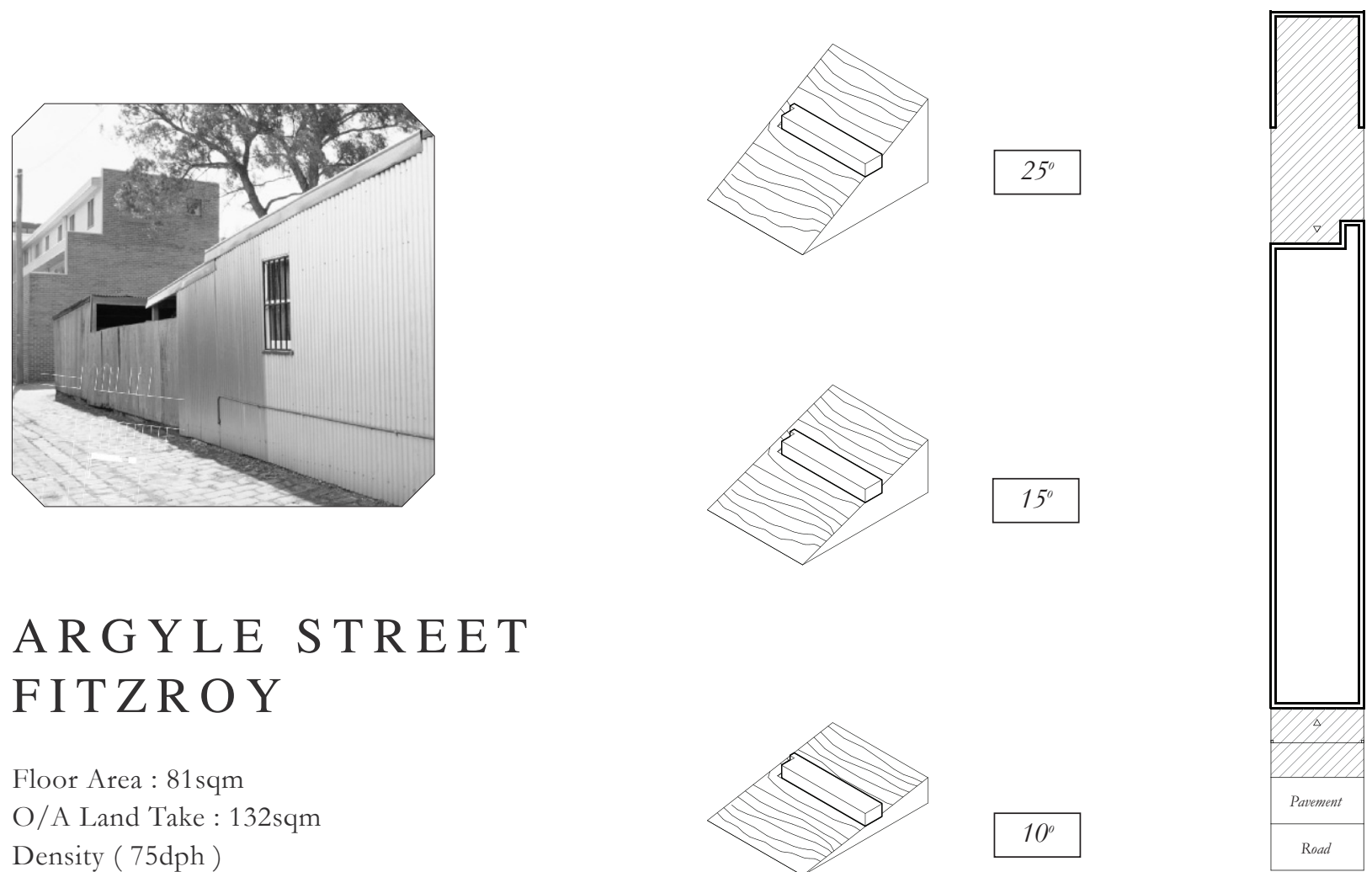

\section{ARG YLE STREET F I T Z R O Y}

Floor Area : 81sqm

O/A Land Take : 132sqm

Density ( $75 \mathrm{dph}$ )

3 Bed 5 People

Flat topography
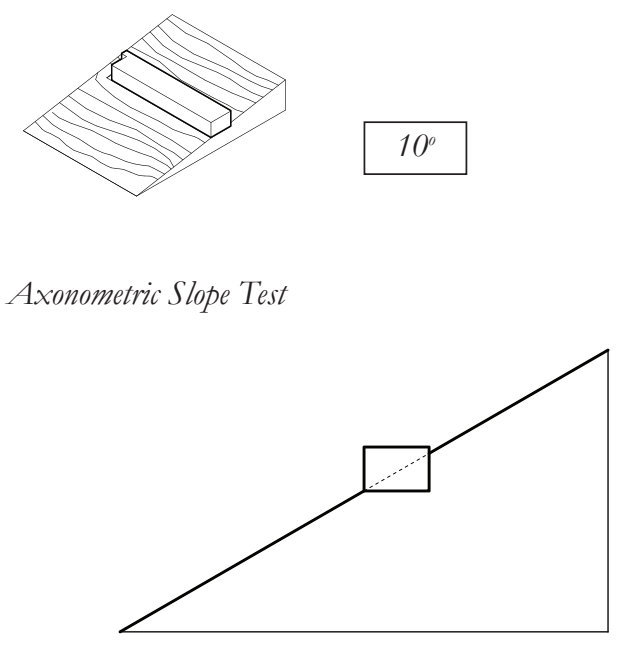

Width : $4 m$

Length : $20 \mathrm{~m}$

Height : 1 Storey

Long and narrow plan aligning best parallel to contours. Low requirement for land excavations. Small front yard and medium rear yard.

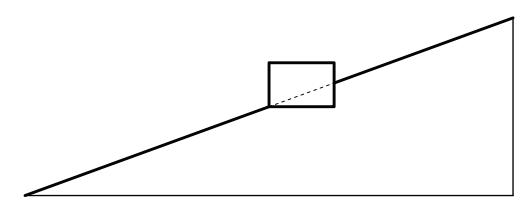

Gains access from GF front;

$10^{\circ}, 15^{\circ}, 25^{\circ}$

Gains access to roof at;

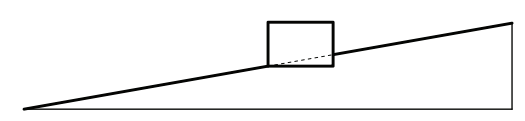
$25^{\circ}$

Sectional Slope Test 

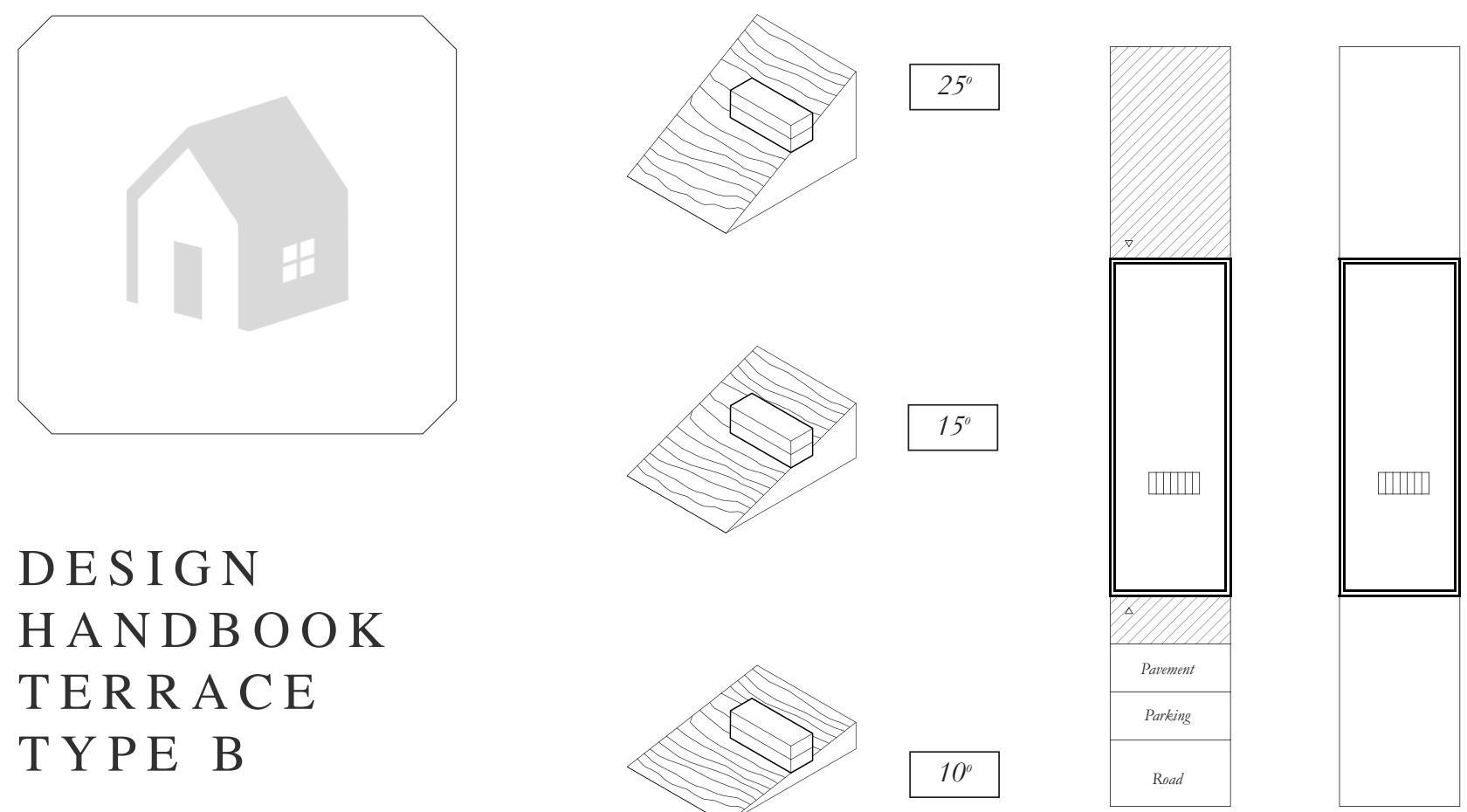

\section{DE S I G N \\ H A N D B O OK \\ TERR A CE $T$ Y PE B}

Floor Area 95sqm

O/A Land Take 135sqm

Density ( $7 \mathrm{dph}$ )

3 Bed 5 People

Flat topography

S U M M A R Y

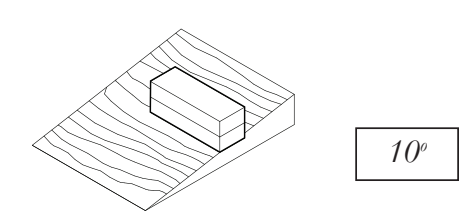

Axonometric Slope Test

Plan

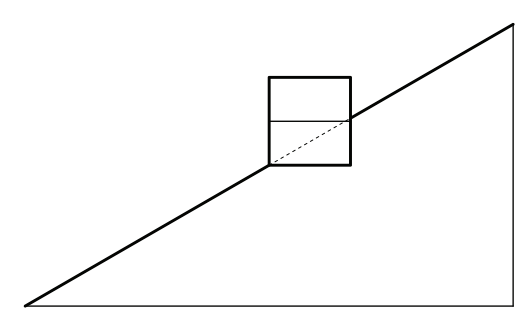

Width : $5 \mathrm{~m}$

Length : $14 m$

Height : 2 Storey

Narrow plan aligning best parallel to contours with central stairwell. Small depth reduces requirement for land excavations. Small front yard and medium rear yard.

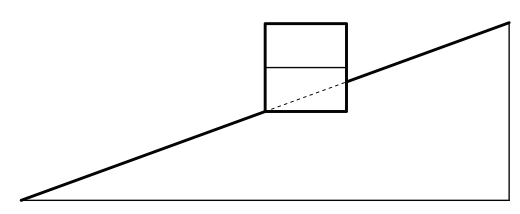

Gains access from GF front; $10^{\circ}, 15^{\circ}, 25^{\circ}$

Gains access to 2nd Floor at;

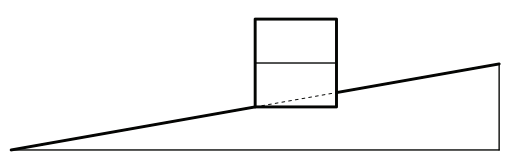
$25^{\circ}$

Sectional Slope Test 


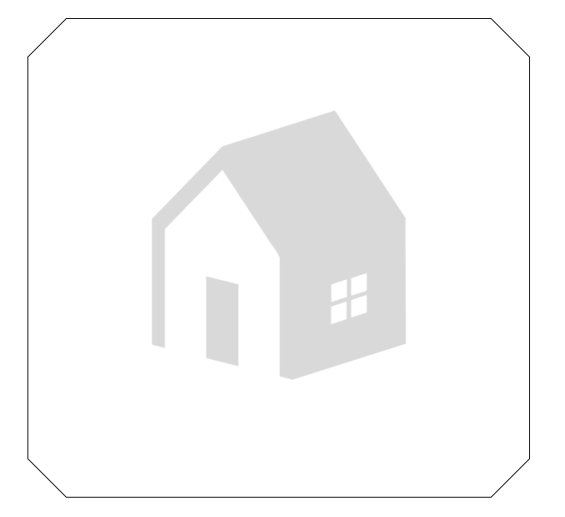

\section{DE S I G N \\ H A N D B O O K \\ TERR A CE \\ TYPE G}

Floor Area 99sqm

O/A Land Take 147sqm

Density (68dph)

3 Bed 5 People

Flat topography
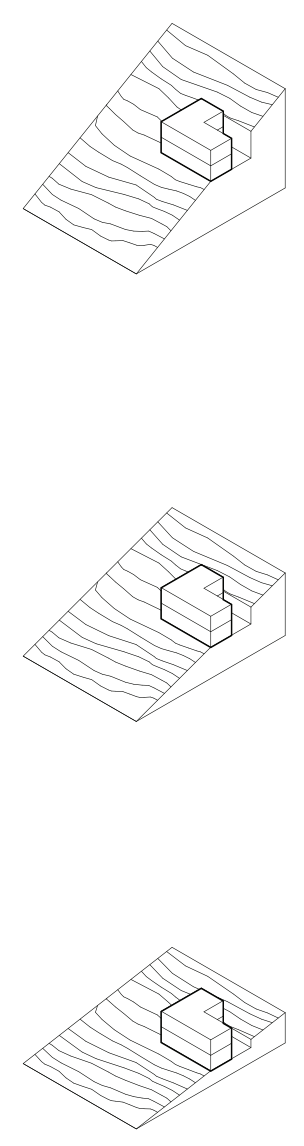

Axonometric Slope Test

\section{S U M M A R Y}

Width $: 8 m$

Length : $10 \mathrm{~m}$

Height : 2 Storey

L' shaped plan with $10 \mathrm{~m}$ length running along contour. Awkward shape and $8 m$ width create high land excavation. Front yard

Access from GF front;

$10^{\circ}, 15^{\circ}, 25^{\circ}$

Gains access to roof at; $25^{\circ}$

Gains access to 2nd floor at; $15^{\circ}$
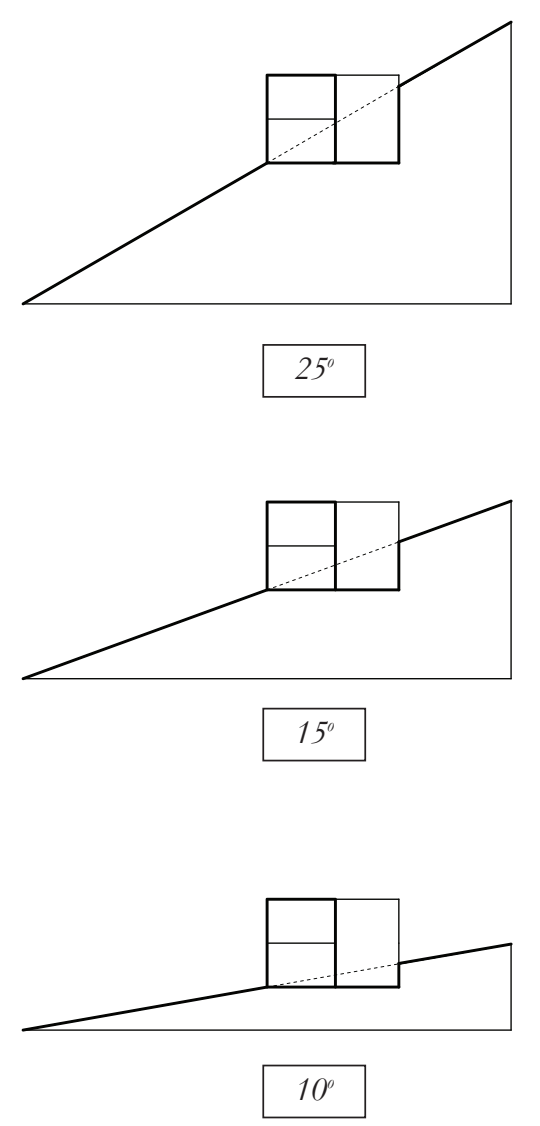

Sectional Slope Test
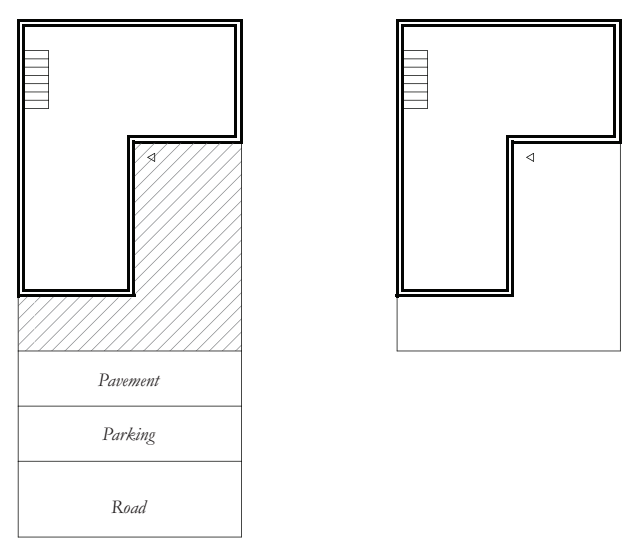

Plan 


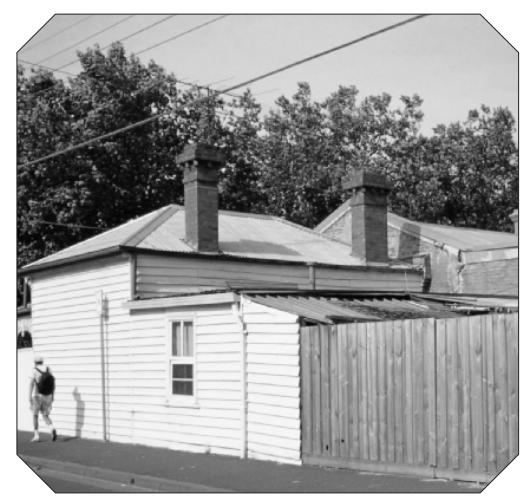

PARK STREET A B B O TS F OR D

Floor Area 105sqm

O/A Land Take 184sqm

Density ( 54dph)

3 Bed 5 People

Flat topography

\section{S UMMARY}

Width $: 8 m$

Length : $17 \mathrm{~m}$

Height : 1 Storey

More suited to flat sites. Building width of $8 m$ limits the amount of daylight into rear rooms. High land excavation for a 1 storey dwelling. Front and rear yards.

Gains access from GF front;

$10^{\circ}, 15^{\circ}, 25^{\circ}$

Gains access to roof at; $15^{\circ}$
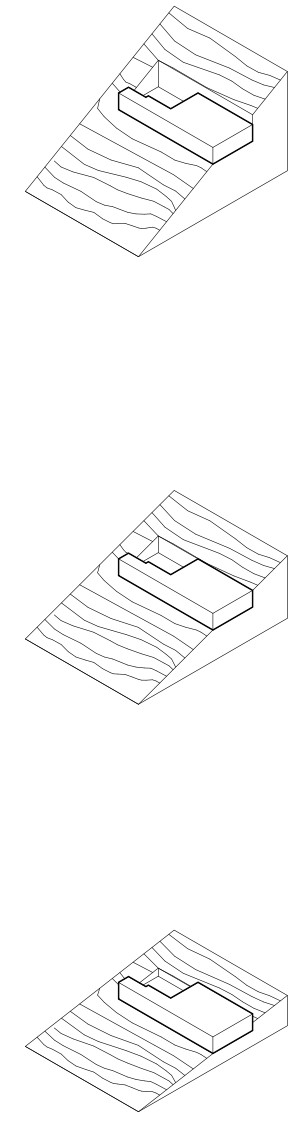

Axonometric Slope Test
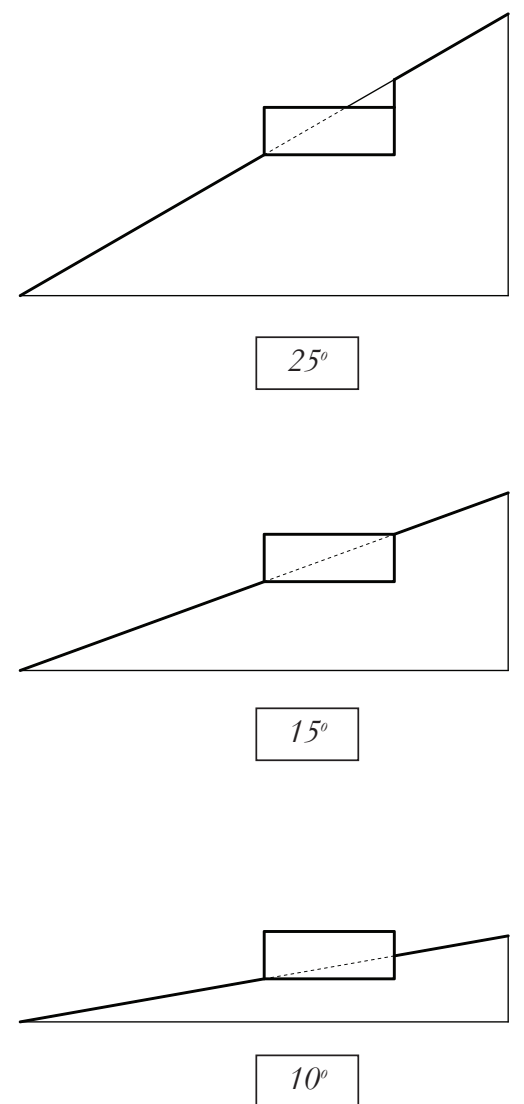

Sectional Slope Test

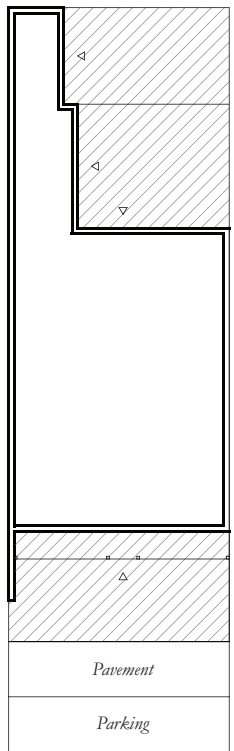

Plan 


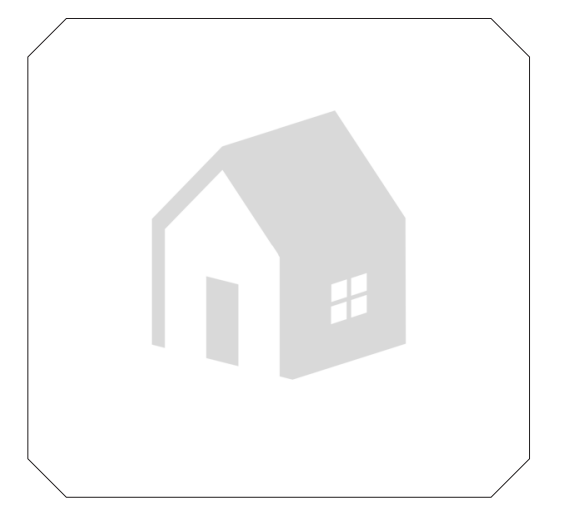

DE S I G N

\section{H A N D B O K}

\section{TERR A CE}

\section{TYPE $F$}

Floor Area 111sqm

O/A Land Take 119sqm

Density ( 84dph )

3 Bed 5 People

Flat topography

S U M M A R Y

Width : $6.5 \mathrm{~m}$

Length : $6.5 \mathrm{~m}$

Height : 3 Storey

Aligns either direction to contours. Low requirement for land excavation considering you gain 90sqm floor area across 3 floors. Good daylight until GF is placed at $25^{\circ}$ Small front yard.

Gains access from GF front;

$10^{\circ}, 15^{\circ}, 25^{\circ}$

Gains access to 2nd floor at; $15^{\circ}$
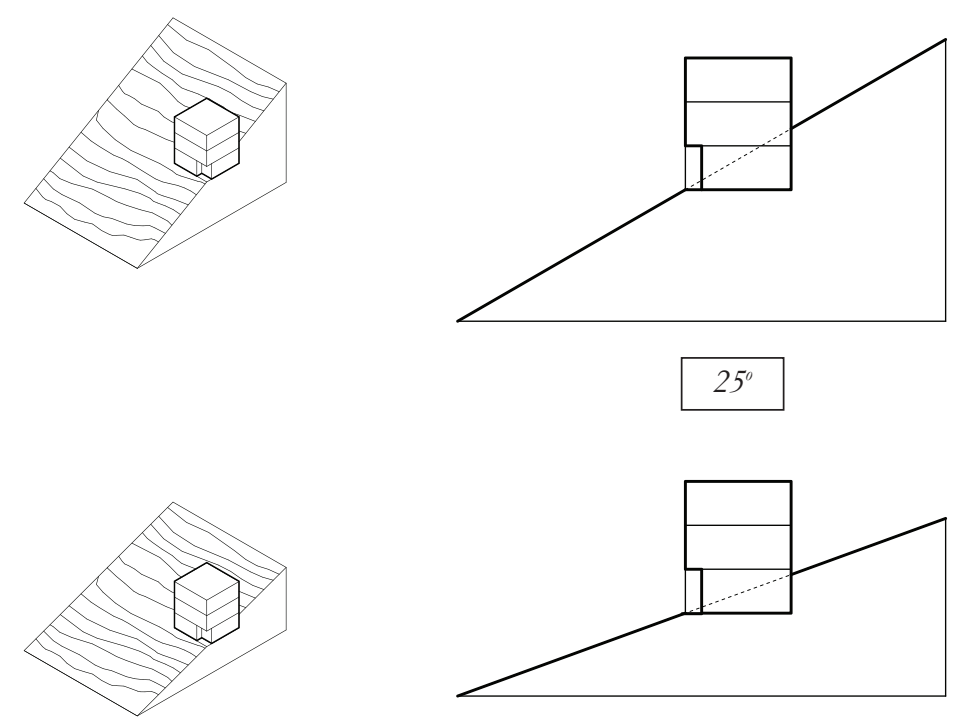

$15^{\circ}$

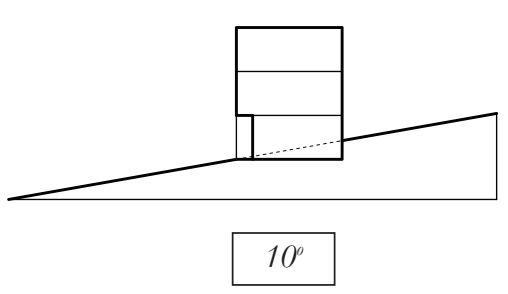

Sectional Slope Test
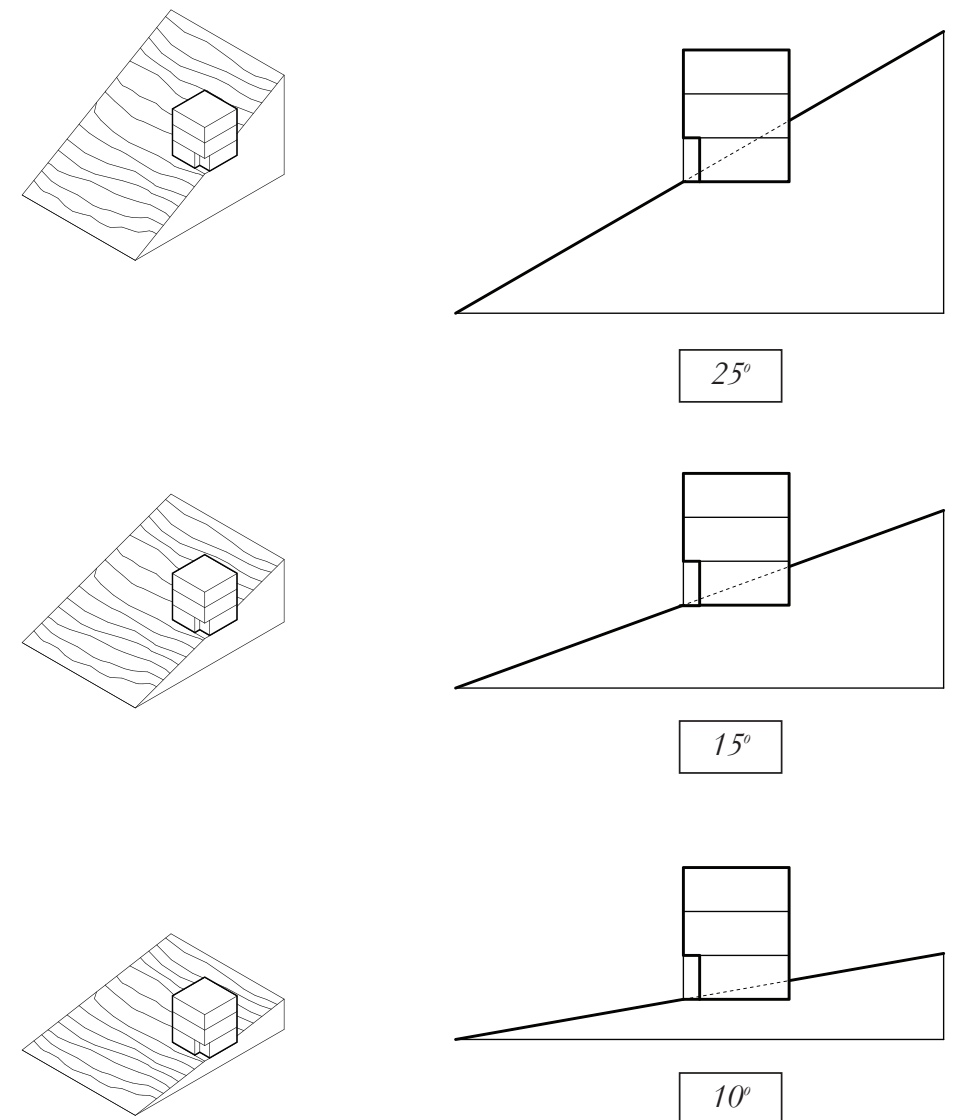

Axonometric Slope Test
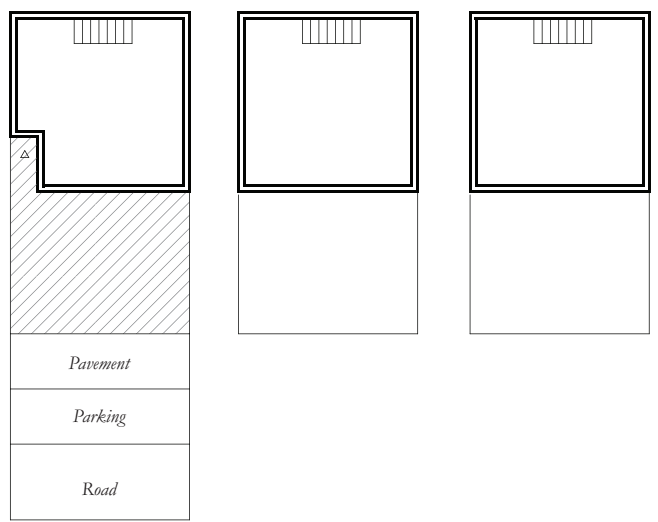

Plan 


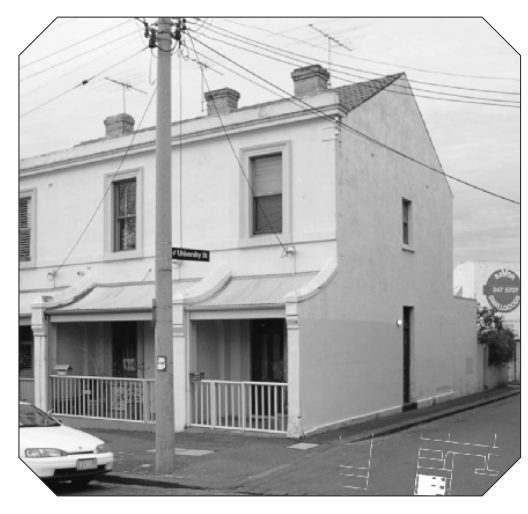

\section{R UMMOND}

\section{STREET,}

\section{ARLTON}

Floor Area 113sqm

O/A Land Take $91 \mathrm{sqm}$

Density ( 109dph )

4 Bed 7 People

Flat topography

\section{S U M M A R Y}

Width : $13 \mathrm{~m}$

Length : $17.5 \mathrm{~m}$

Height : 2 Storey

Long length requires large land excavation. GF loses considerable daylight at all slopes. Medium front yard and small rear yards.

Gains access from GF front; $10^{\circ}, 15^{\circ}, 25^{\circ}$

Gains access to roof at; $15^{\circ}$

Gains access to 2nd floor at; $10^{\circ}$
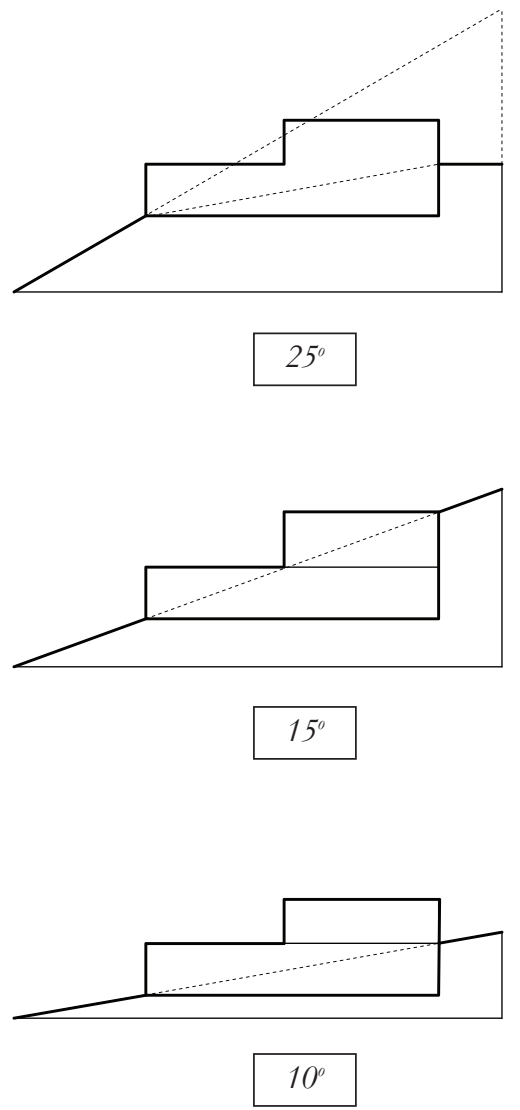

Sectional Slope Test
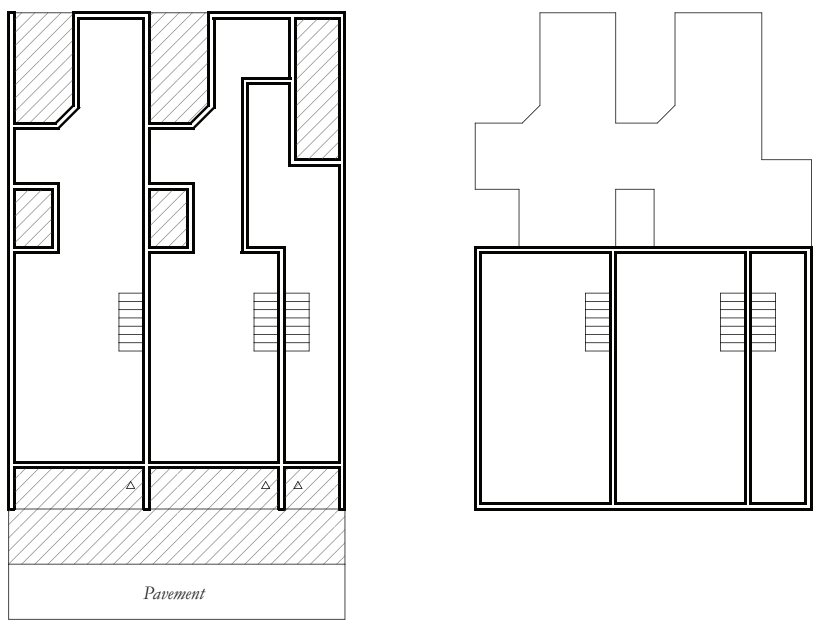


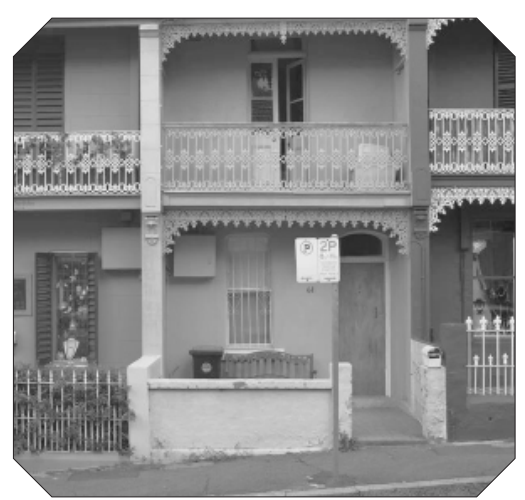

\section{PA D D INGTON}

\section{TERRACE,} $S$ Y DNEY

Floor Area 117sqm

O/A Land Take 130sqm

Density ( 76dph )

3 Bed 5 People

Flat topography

S U M M A R Y

Width : $5 \mathrm{~m}$

Length : $17.5 \mathrm{~m}$

Height : 2 Storey

Longer length and narrow width fits most slopes well when postioned along contour.

Would benefit from a third level. Front and rear yards

Gains access from GF front;

$10^{\circ}, 15^{\circ}, 25^{\circ}$

Gains access to 2nd floor at; $15^{\circ}$
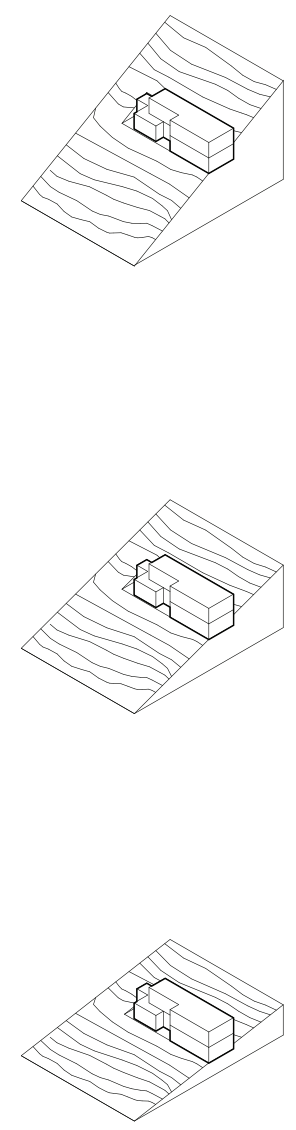

Axonometric Slope Test
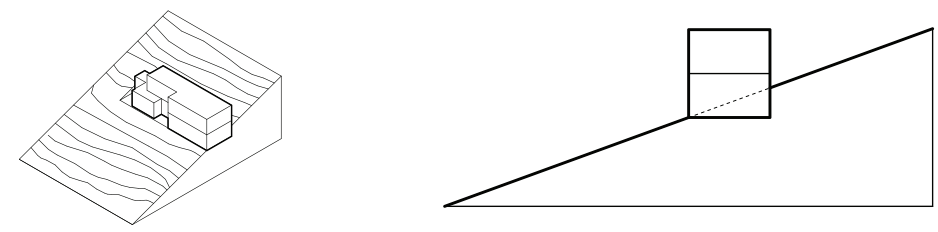

$15^{\circ}$

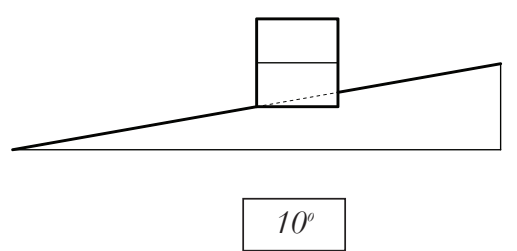

Sectional Slope Test

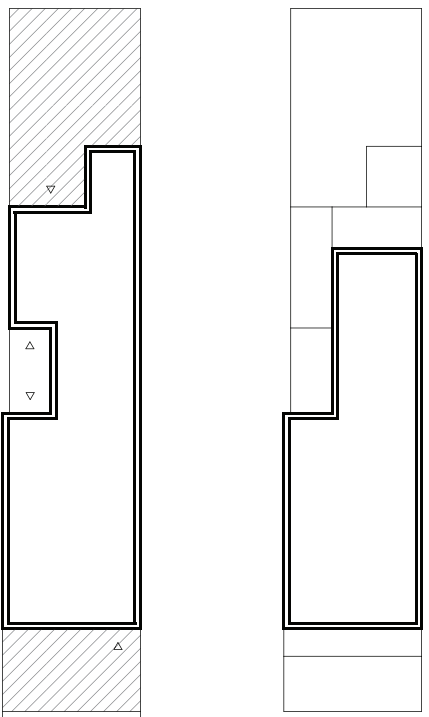

Plan 


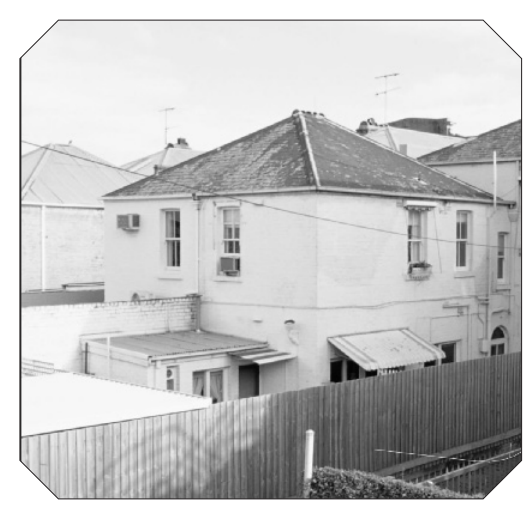

GR AT TA N

S T REET,

\section{ARLTON}

Floor Area 195sqm

O/A Land Take 266sqm

Density ( $37 \mathrm{dph}$ )

5 Bed 9 People

Flat topography

S U M M A R Y

Width : $12.5 \mathrm{~m}$

Length : $19 \mathrm{~m}$

Height : 2 Storey

Long length mean GF gains minimal sun when cut into topography. 2nd Floor function well at $10^{\circ}$ slope. Small front yard and large rear yard.

Gains access from GF front; $10^{\circ}, 15^{\circ}, 25^{\circ}$

Gains access to 2nd floor at; $10^{\circ}$
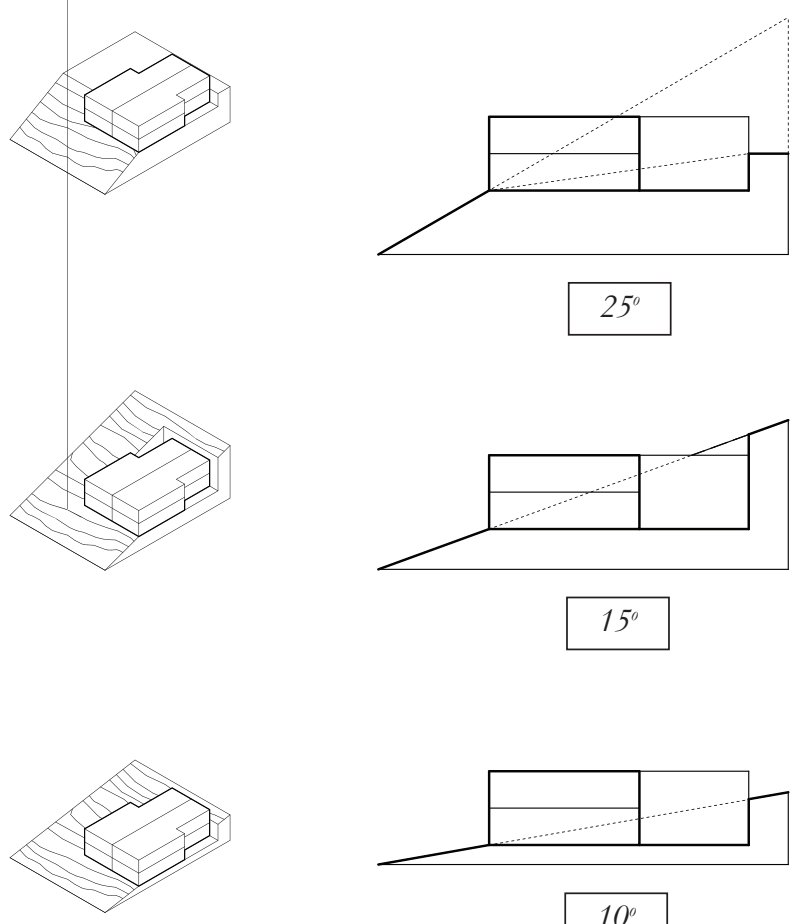

Axonometric Slope Test
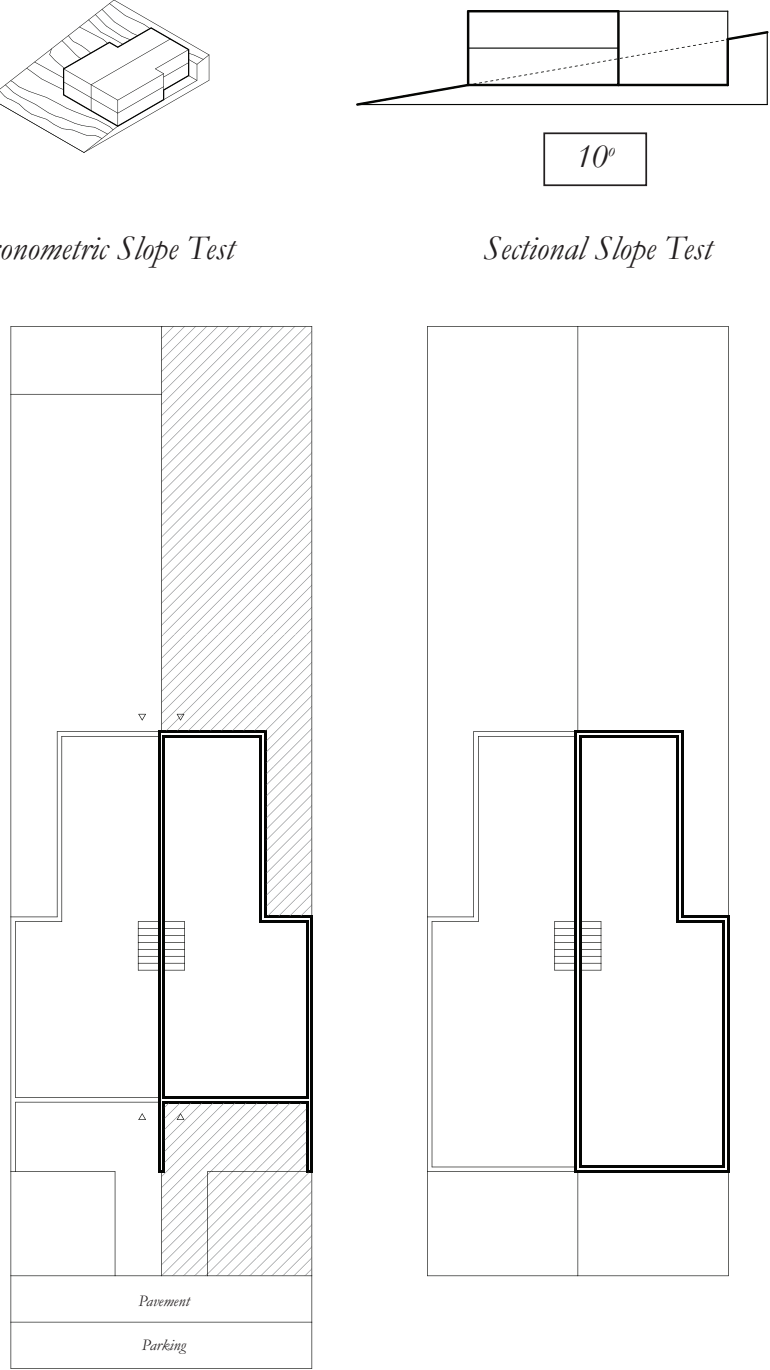

Sectional Slope Test

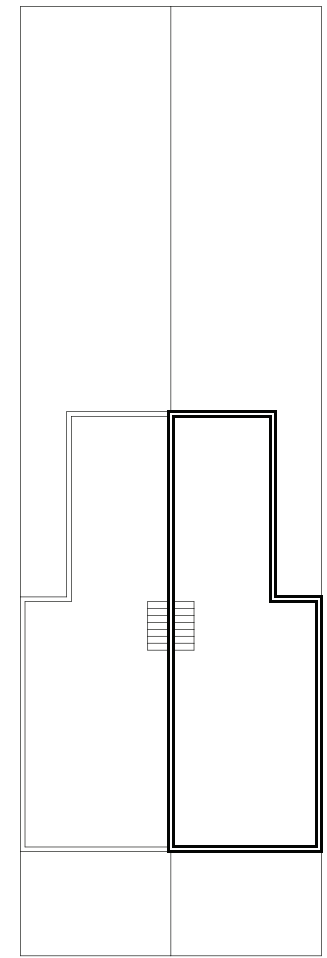

Plan 


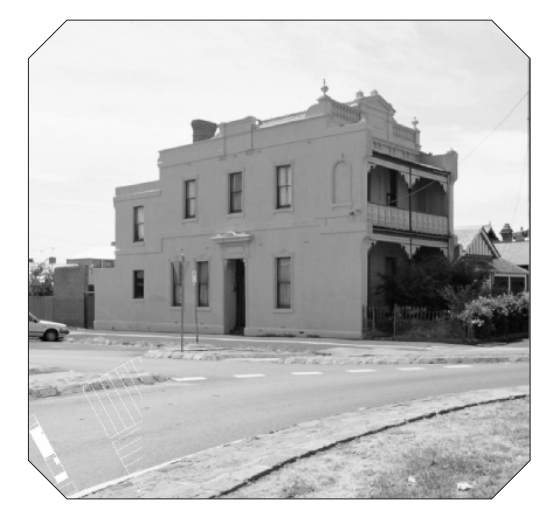

M I C H A E L

STREET,

\section{CLIFTON HILL}

Floor Area 237sqm

O/A Land Take 280sqm

Density (35dph)

35 Bed 9 People

Flat topography

S U M M A R Y

Width : $7 m$

Length : $32 \mathrm{~m}$

Height : 2 Storey

Longer length and narrow width fits along contour. Building mass becomes unpractical at $25^{\circ}$ as land excavation increases and daylight become hard to attain in rear rooms. Front and rear yards

Gains access from GF front; $10^{\circ}, 15^{\circ}, 25^{\circ}$

Gains access to 2nd floor at; $15^{\circ}$
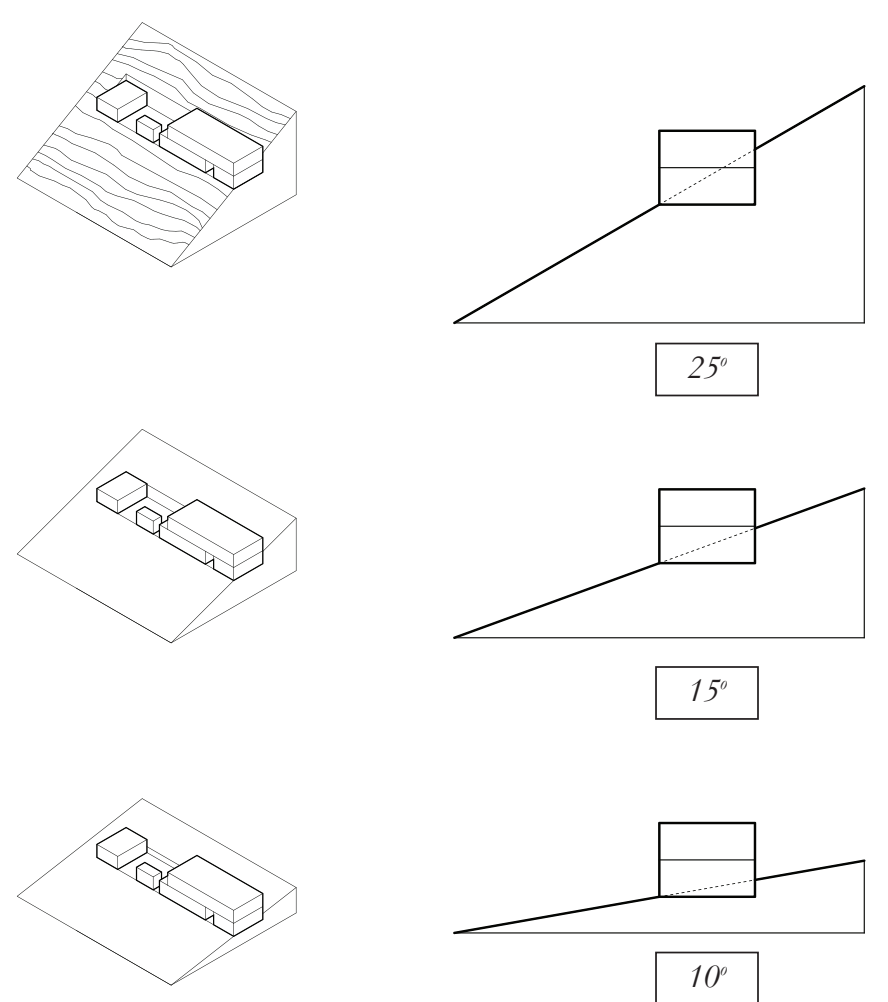

Axonometric Slope Test

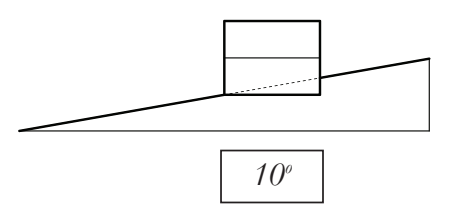

Sectional Slope Test
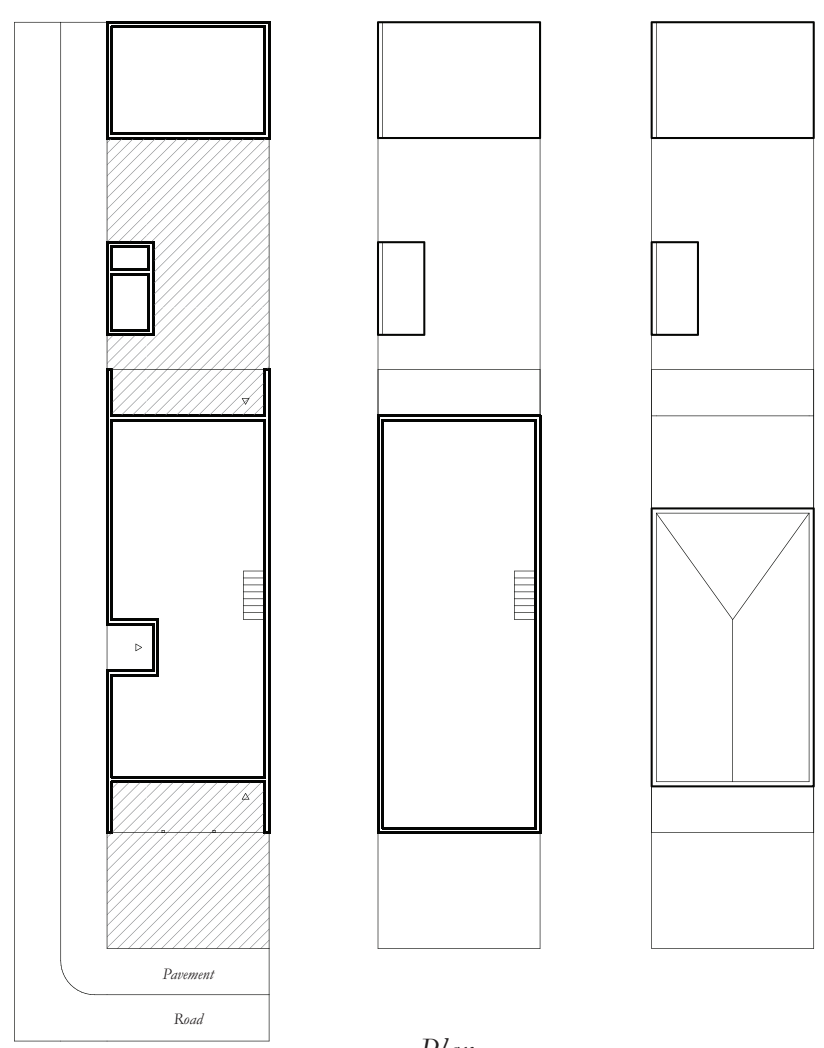

Plan 

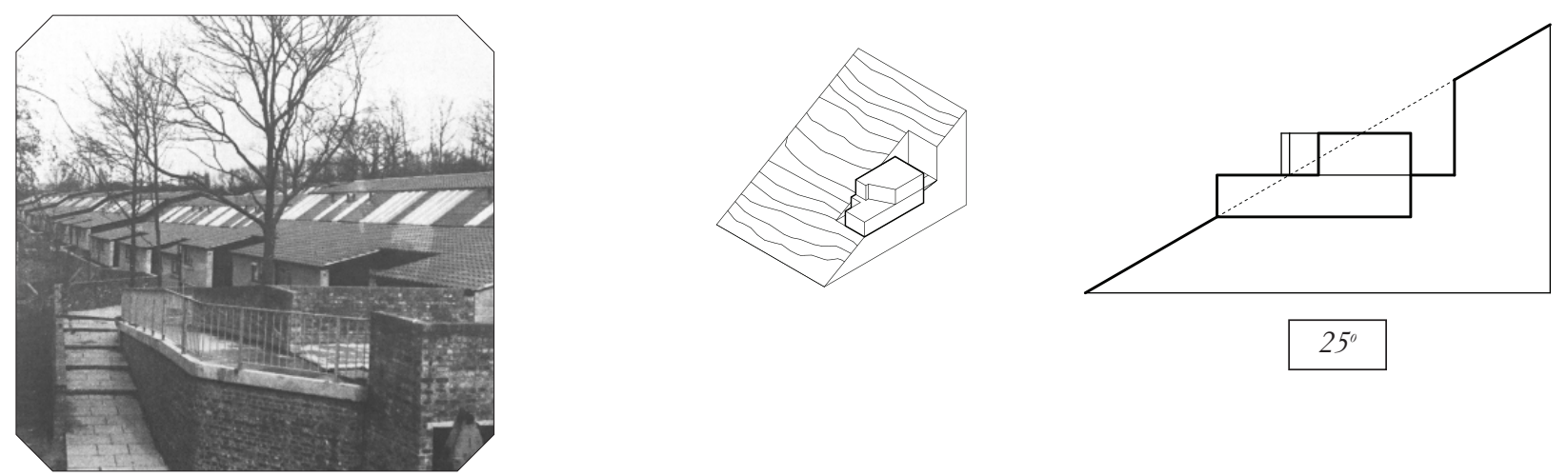

\section{LANGDON HILLS E S S EX, E N G L A N D}

Parallel Terrace
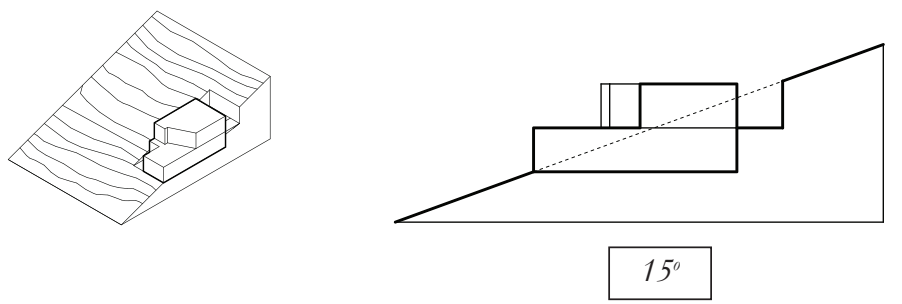

Clive Plumb + Douglas Galloway

Floor Area 106sqm

O/A Land Take 105sqm

Density (49dph)

3 Bed 5 People

Slope Topography

Gradient 1:10 ( 5.7 degrees )
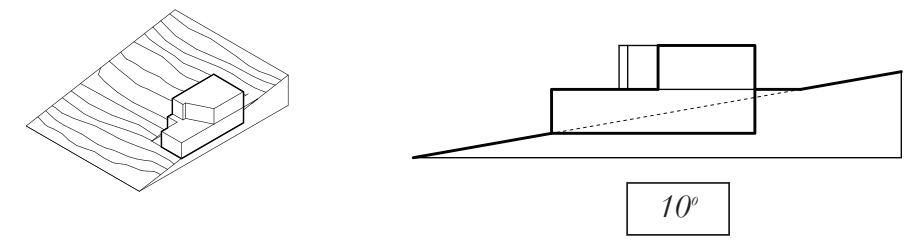

Axonometric Slope Test

Sectional Slope Test

\section{S U M M A R Y}

Width : $6 \mathrm{~m}$

Length : $12.5 \mathrm{~m}$

Height : 2 Storey

Longer length was placed against contours to develop a stepping form. Massing suits mild slopes as daylight is again lost in rear room on lower floor. Front yard

Gains access from GF front;

$10^{\circ}, 15^{\circ}, 25^{\circ}$
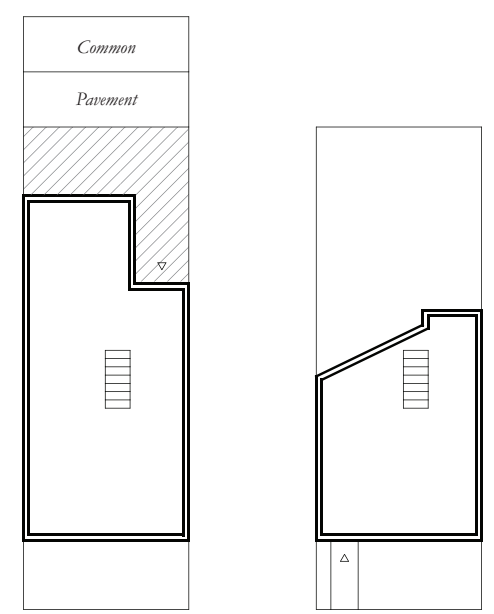

Gains access to 2nd floor at; $10^{\circ}$ 


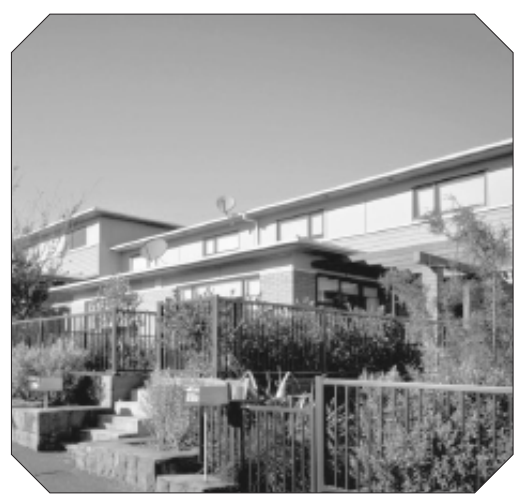

\section{DUKE STREET THREE KINGS, A UCKLAND}

Floor Area $117 \mathrm{sqm}$

O/A Land Take 130sqm

Density (31dph )

3 Bed 5 People

Slope Topography

Gradient 1:20 ( 3 degrees )

Axonometric Slope Test

S U M M A R Y

Width : $8 m$

Length : $15 \mathrm{~m}$

Height : 2 Storey

Orientation of massing along contour creates closer relationship to topography. Narrow GF reduces excavation while 2nd floor extends back until it reaches the slope. Front and rear yards

Gains access from GF front;

$10^{\circ}, 15^{\circ}, 25^{\circ}$

Gains access to 2nd floor at; $15^{\circ}$
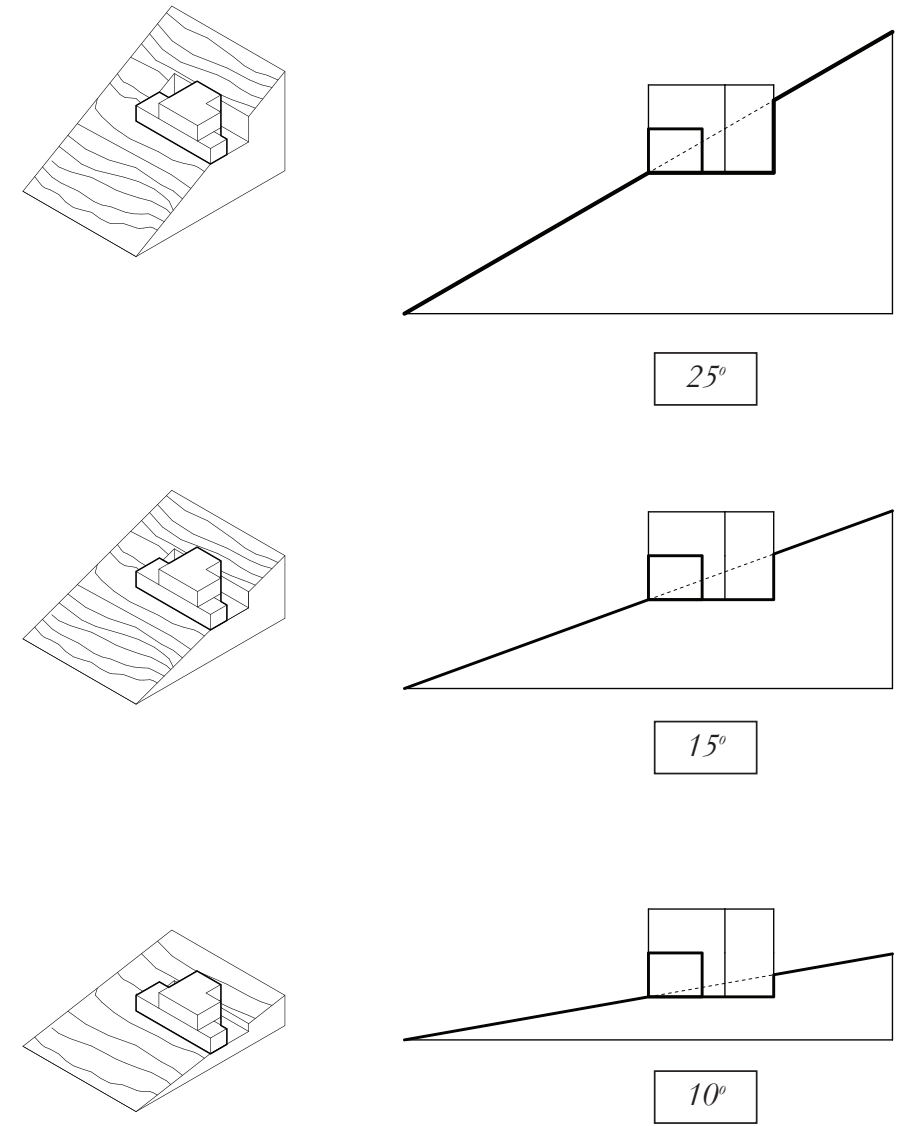

Sectional Slope Test
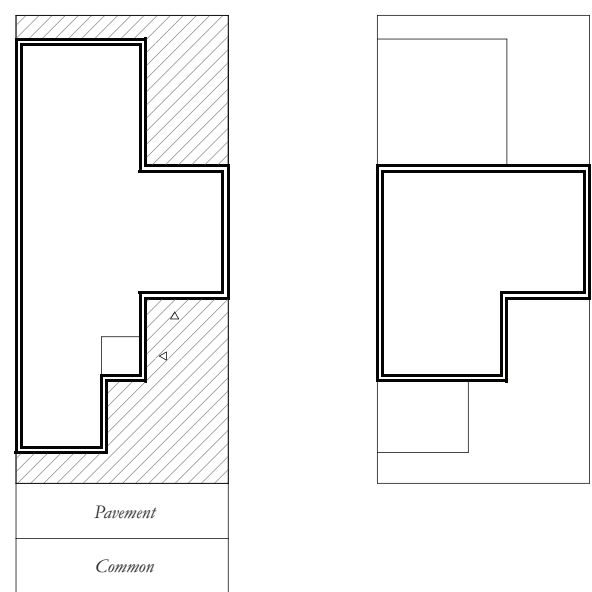

Plan 


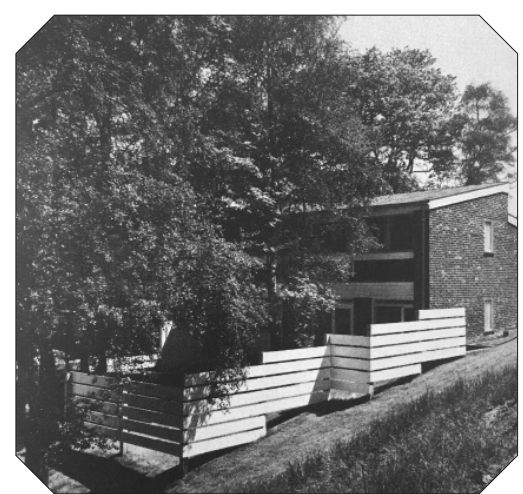

PECK A R M A N S W OOD

\section{DULW I C H,} L O N D N

Split-level Terrace

Floor Area 188sqm

O/A Land Take 205sqm

Density (48dph)

4 Bed 7 People

Slope Topography

Gradient 1:6 ( 9 Degrees)

\section{S U M M A R Y}

Width : $12 \mathrm{~m}$

Length : $10 \mathrm{~m}$

Height : 2 Storey

Aligns either direction to contours. Mild requirement for land excavation considering you gain 188 sqm floor area across two floors. Could be increased to three floors. Reasonable daylight. Small front yard and rearyards.

Gains access from GF front; $10^{\circ}, 15^{\circ}, 25^{\circ}$

Gains access to 2nd floor at;
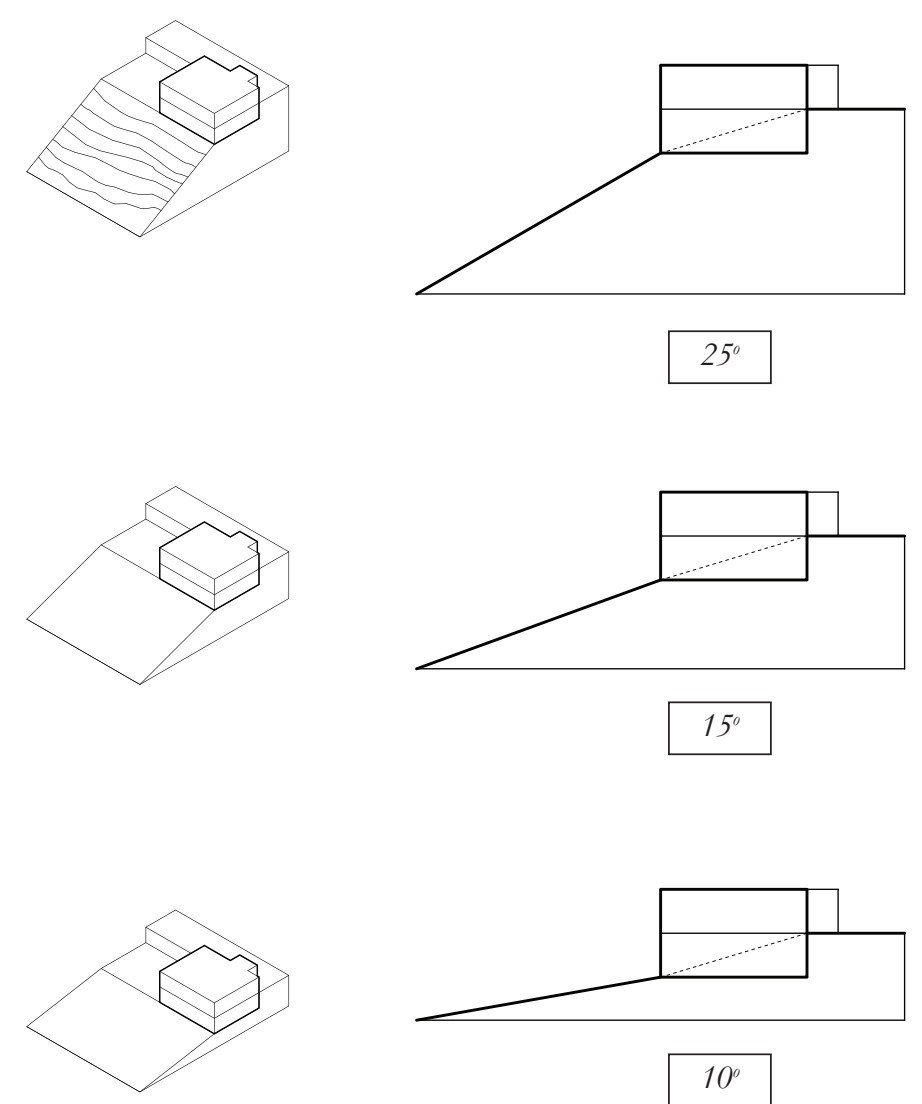

Axonometric Slope Test

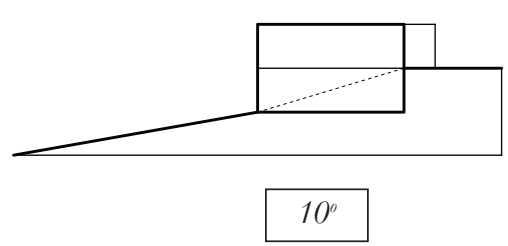

Sectional Slope Test
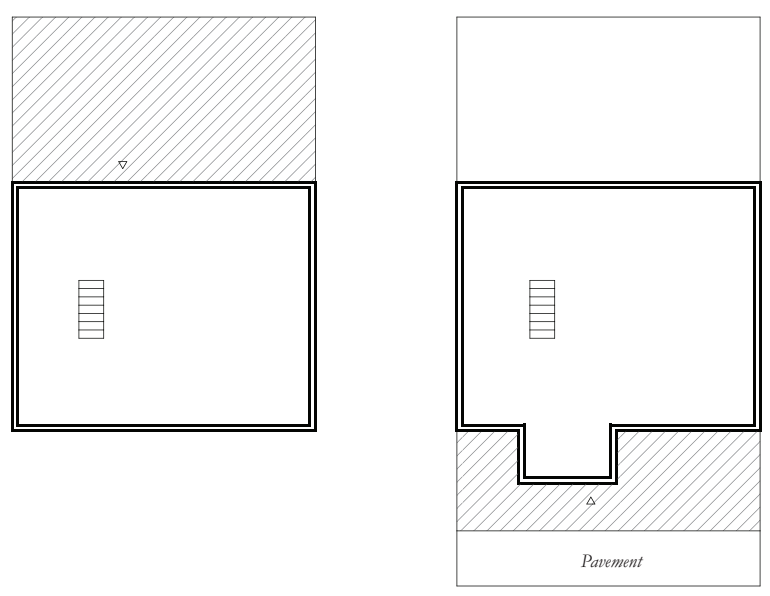

Plan 


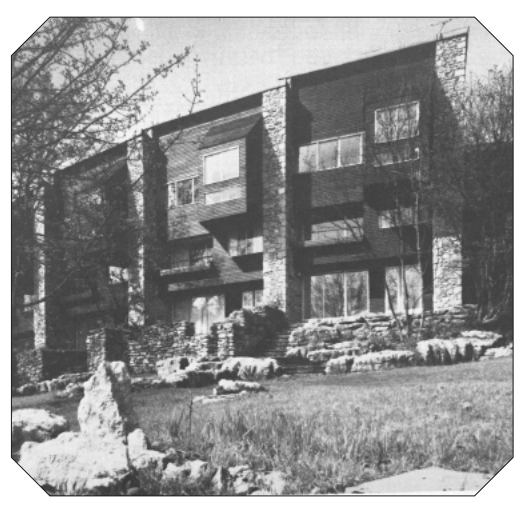

B EETH A M

\section{UM B R I A}

Curved Terrace/Rural site

Floor Area 194sqm

O/A Land Take 121sqm

Density ( 82dph)

4 Bed 6 People

Slope Topography

Gradient 1:5 ( 11 degrees )

\section{S U M M A R Y}

Width : $7.5 \mathrm{~m}$

Length : $13 \mathrm{~m}$

Height : 3 Storey

Attached row is designed to face each dwelling against contour, however the attached row of dwellings runs along the contour. direction to contours. Mild requirement for land excavation Good daylight. Small front yard.

Gains access from GF front; $10^{\circ}, 15^{\circ}, 25^{\circ}$

Gains access to 2nd floor at; $10^{\circ}$
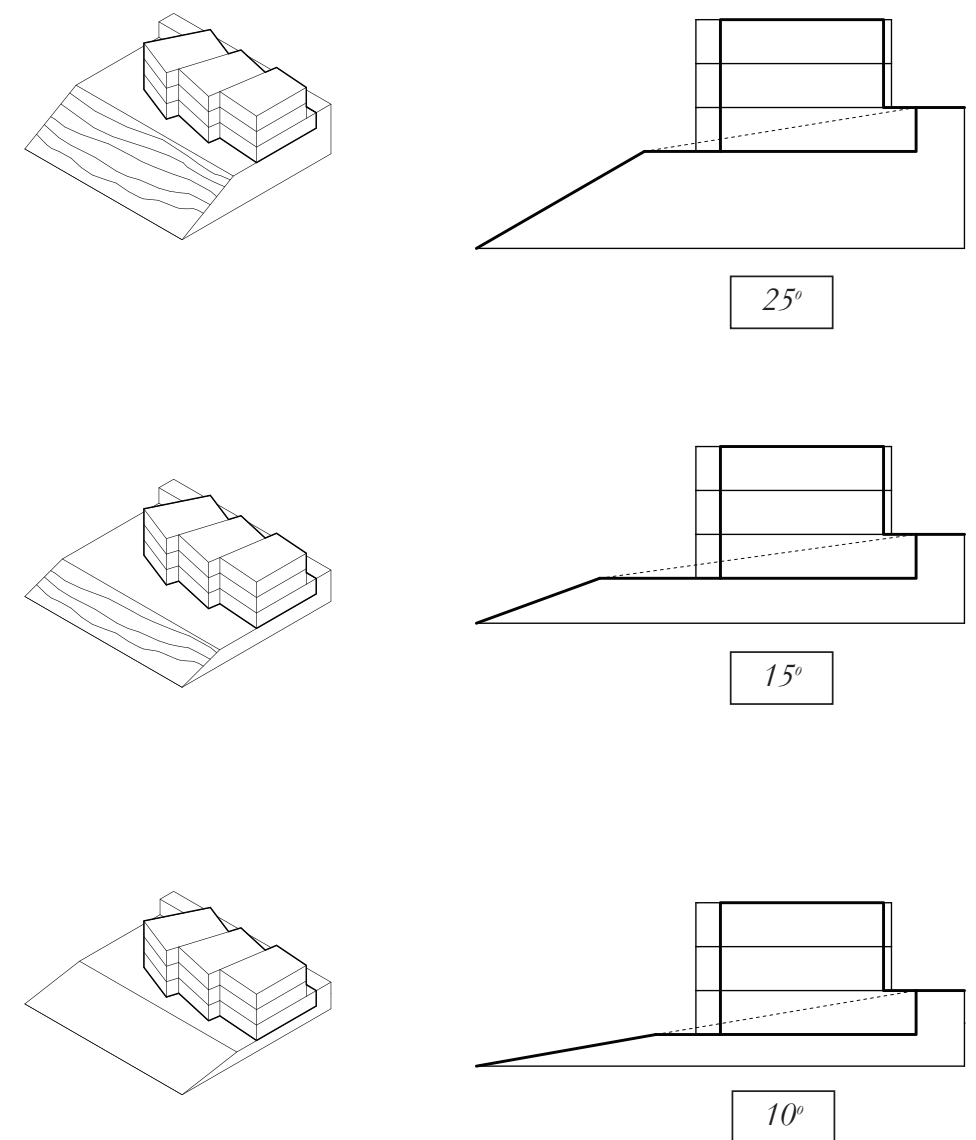

Axonometric Slope Test

Sectional Slope Test
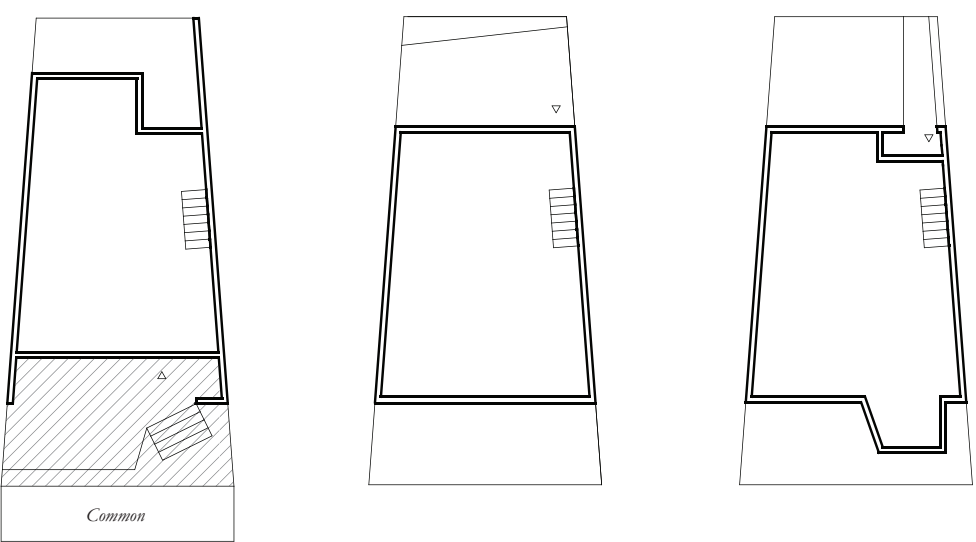

Plan 


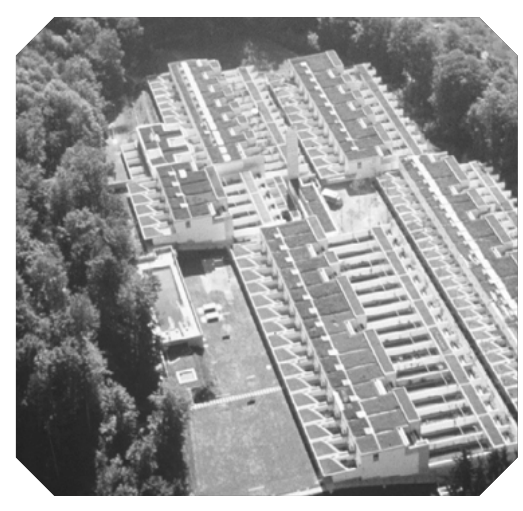

\section{S IE D L UNG}

\section{H A L EN}

Stepped Housing

Floor Area 720sqm

O/A Land Take 460sqm

Density (110dph )

Unit size vary

Slope Topography

Gradient 1:5 ( 11 degrees )

\section{S U M M A R Y}

Width : $6 \mathrm{~m}$

Length : Variable, $40 \mathrm{~m}$

Height : 3 Storey

Multiple level, stepped dwellings create access from front and rear yards at different levels. Built form and landscaping combine to create a terracing typology.

Gains access from GF front;

$10^{\circ}, 15^{\circ}, 25^{\circ}$

Gains access to 2nd dwelling at; $10^{\circ}, 15^{\circ}, 25^{\circ}$
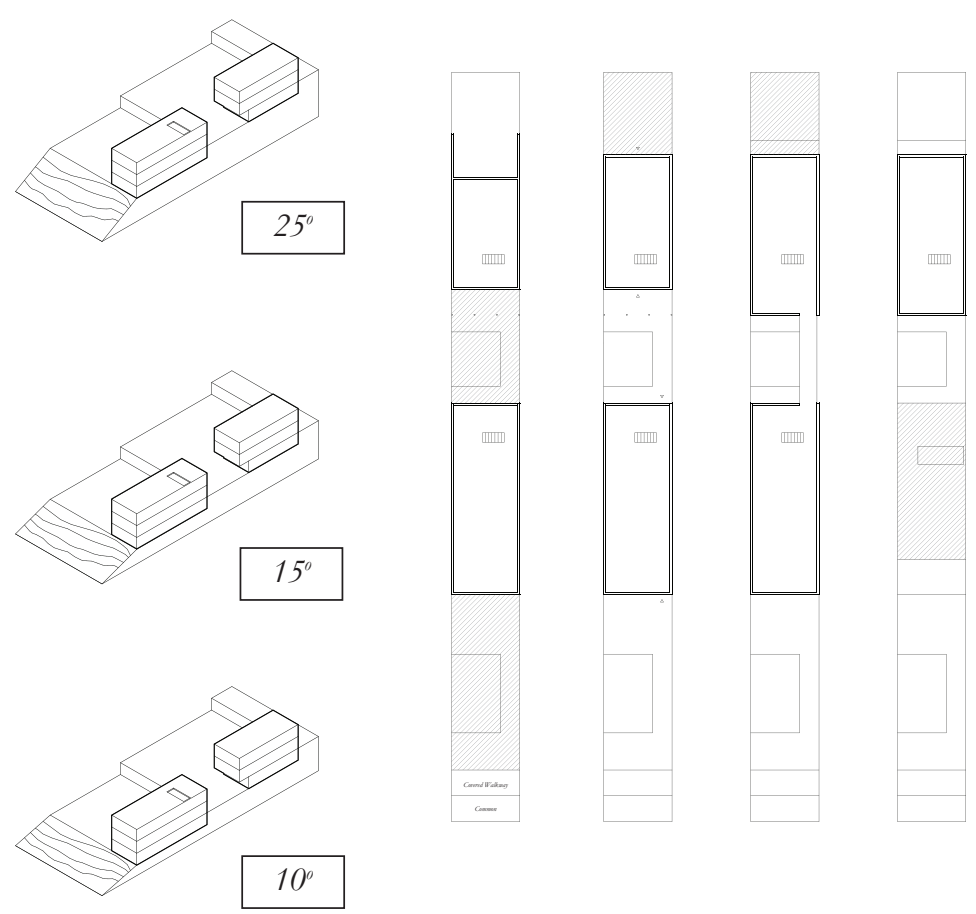

\section{$10^{\circ}$}

Axonometric Slope Test

Plan
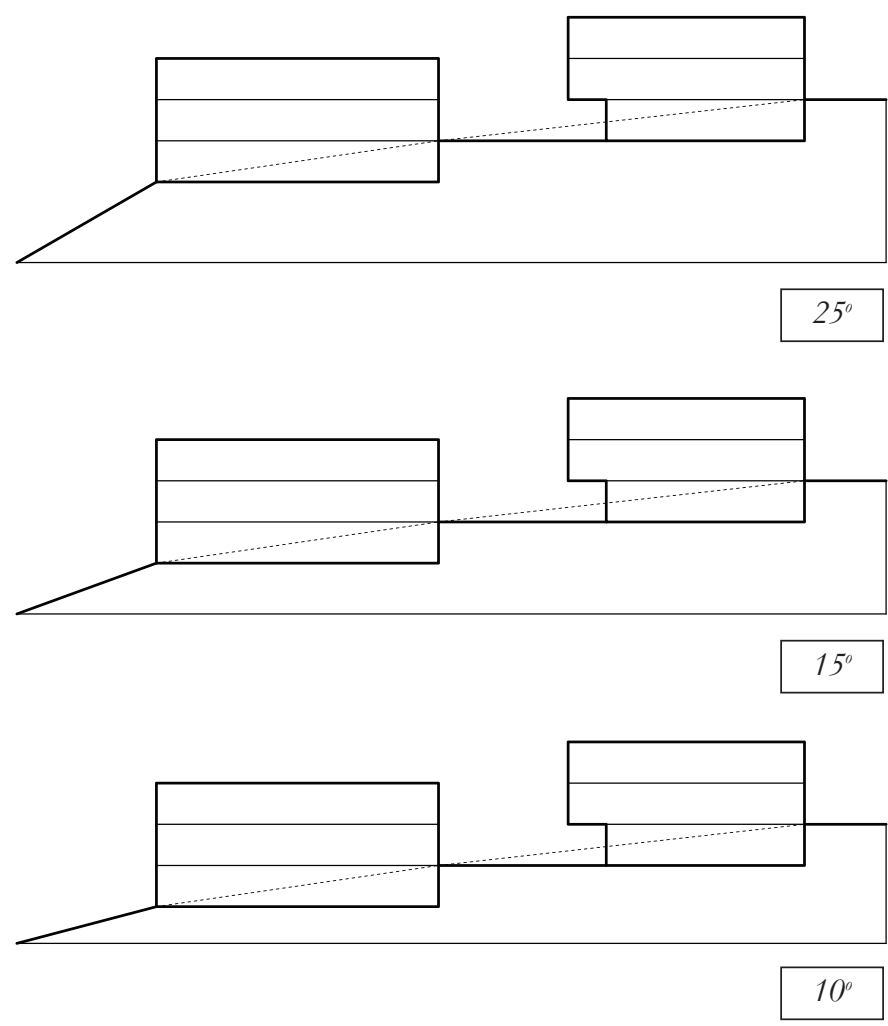

Sectional Slope Test 


\title{
BUILT FORM \& TOPOGRAPHY
}

\author{
DESIGN STUDY
}

The terrace inventory illustrated how different displays of built form can respond to variable slopes. The next two pages include short design studies that are a reflection and development upon topography analysis II. The process involves applying built form to the existing site while altering room depths and floor levels to respond to slope gradient.

Spaces between built form are conceptualized as thoroughfares for the residents. Stepping the dwellings up the hillside and reducing the ground floor depth created less excavation to the natural slopes. Different typologies are explored to occupy the hillside.

o Dwellings are arranged as an attached row moving along the hill contours

o Building depth is adapted depending on slope

o Building heights are increased to three levels to improve density

o Built form is spaced at a distance to allow sunlight for streets

o Dwellings accessed from street have setbacks at entrances to improve privacy

o Level changes promote interesting thresholds between built form

$>$

Figure 71 // Section; built form and topography exploration 

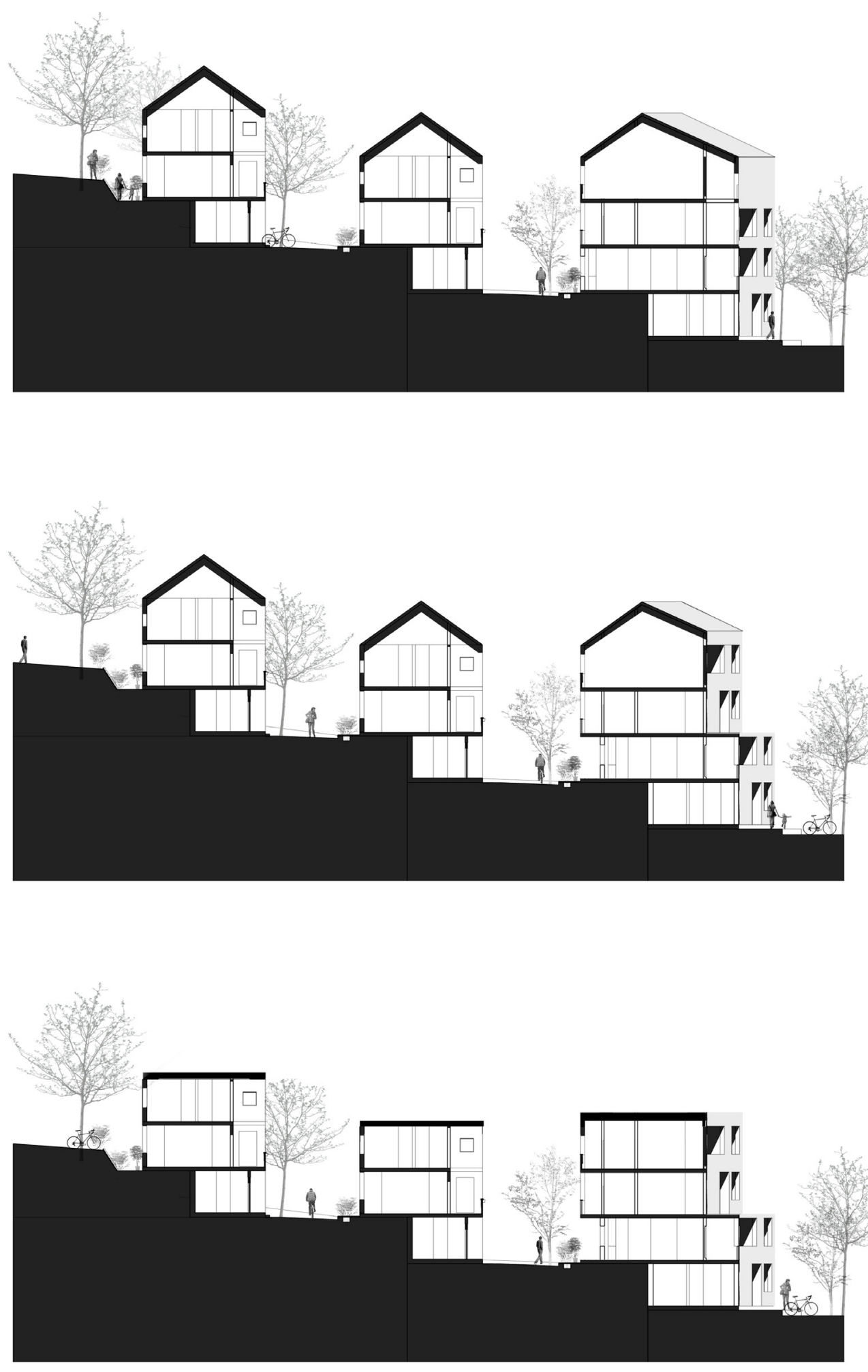

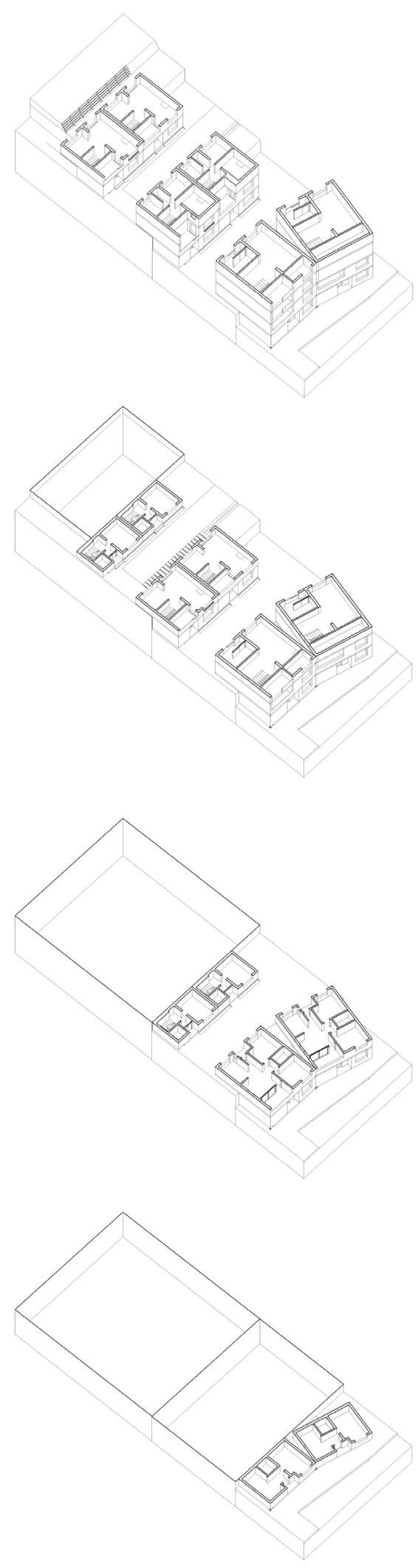

$\wedge$ 

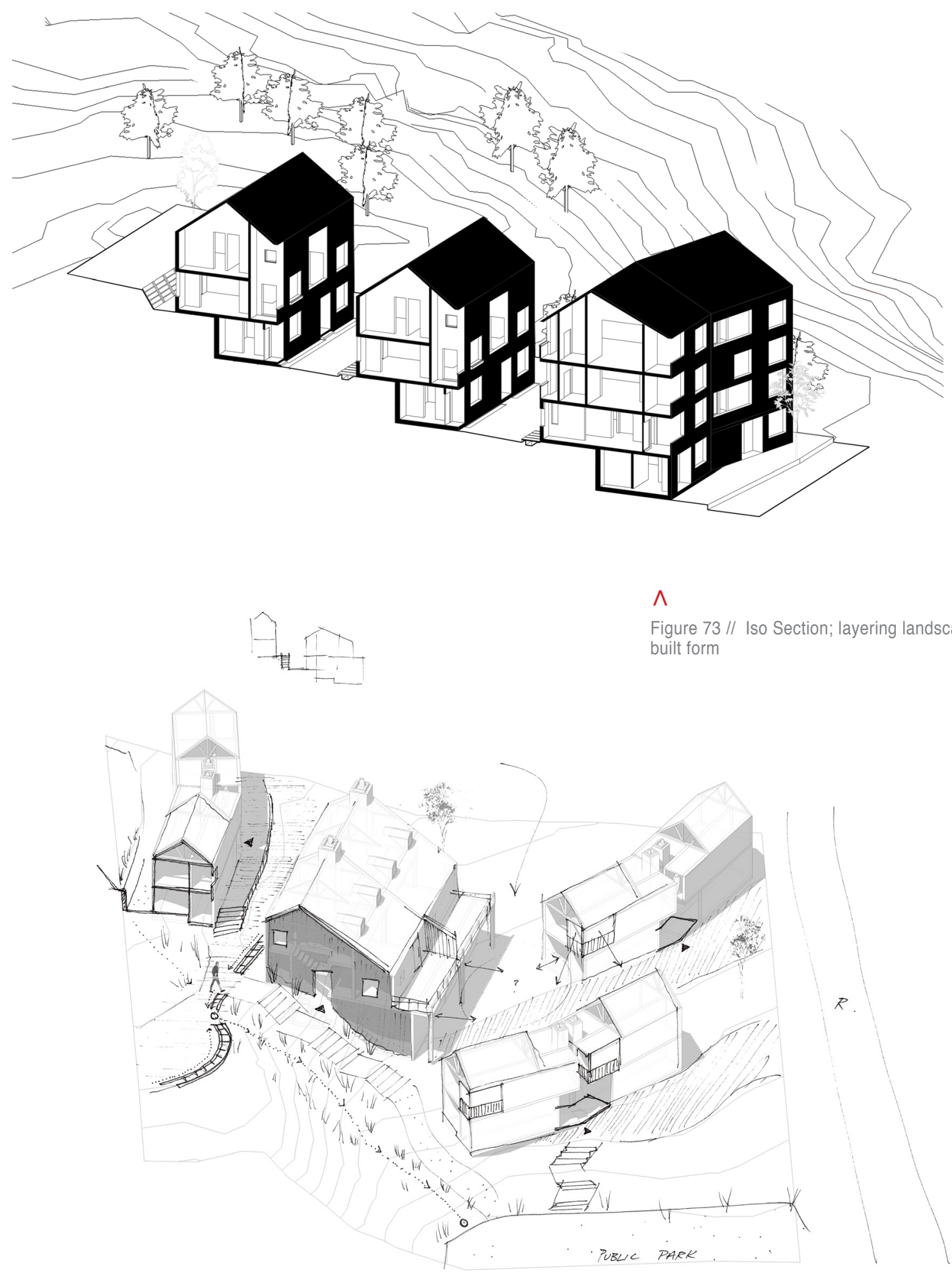


\title{
TERRACE INVENTORY REFLECTION
}

\author{
I N S UMMARY
}

The research involved identification of slopes and landforms that followed with an investigation into the application of built form on to slope. The topography analysis and slope maps provided evidence of a variety in slope gradients and landform on the Rolleston Street site. The quantitative slope results were categorized into a qualitative classification, which summarized the site as having gentle, moderate, strong and steep gradients - typically ranging between $1^{\circ}-20^{\circ}$.

Application of built form was the next phase in the topography research and an inventory of terraced housing located on flat and sloped topography was tested. The application of precedents designed for flat sites was to acknowledge problems associated when this typology is applied to hill sites. This is similar to and reflects the existing site built form and display.

Design outcomes testing flat topography housing on to sloped sites;

o Shorter width was typically placed running along contours - Design Handbook Terrace Type F displayed 6-7m was the most ideal width as it allowed suitable daylight for all three floors

o Large excavation of land required to site building mass

o Built form is constructed vertically with no offsets in upper floors

Design outcomes testing sloped topography housing onto sloped sites;

o Stepped dwellings display deeper built form width and provide daylight to rear rooms - Siedlung Halen and Langdon Hills begin to show this.

o Less excavation required as built form is more suited to slopes

o Offsetting upper floors to fit slope more appropriately 


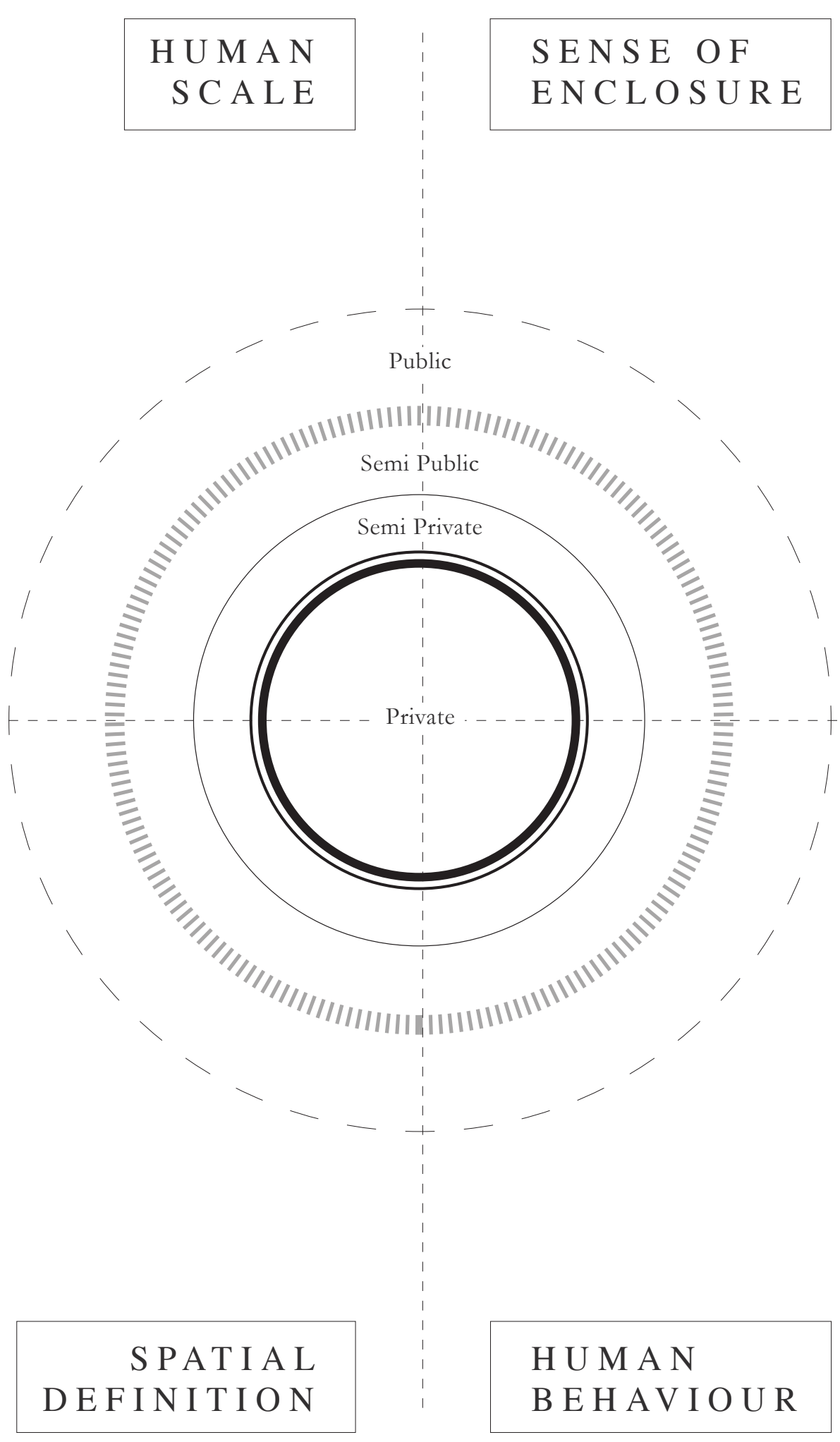




\section{DEFINING TERRITORY \& PRIVACY}

'Only architecture that considers buman scale and interaction is successful architecture.' Jan Gebl

The following analysis explores the extent to which built form can define territory and demarcate privacy. It demonstrates how building envelopes - their scale, proportion and extent of openings - can enclose or expose the occupant and influence their experience.

These components are vital for influencing the degree of privacy experienced at a human scale. The study is relative to the densification project by exploring how a continuity of spaces can be achieved by ensuring a clear definition between the public, common and private realm.

$<$

Figure 75 // Diagram; Jan Gehl's degree of privacy 


\section{SCALE \& OPEN INGS}

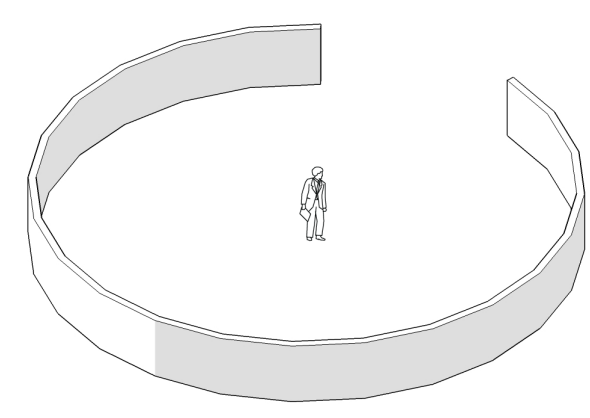

Larger scale; courtyard, plaza, foyer, park

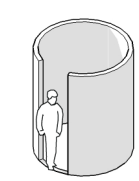

Smaller scale; street, room, stairs
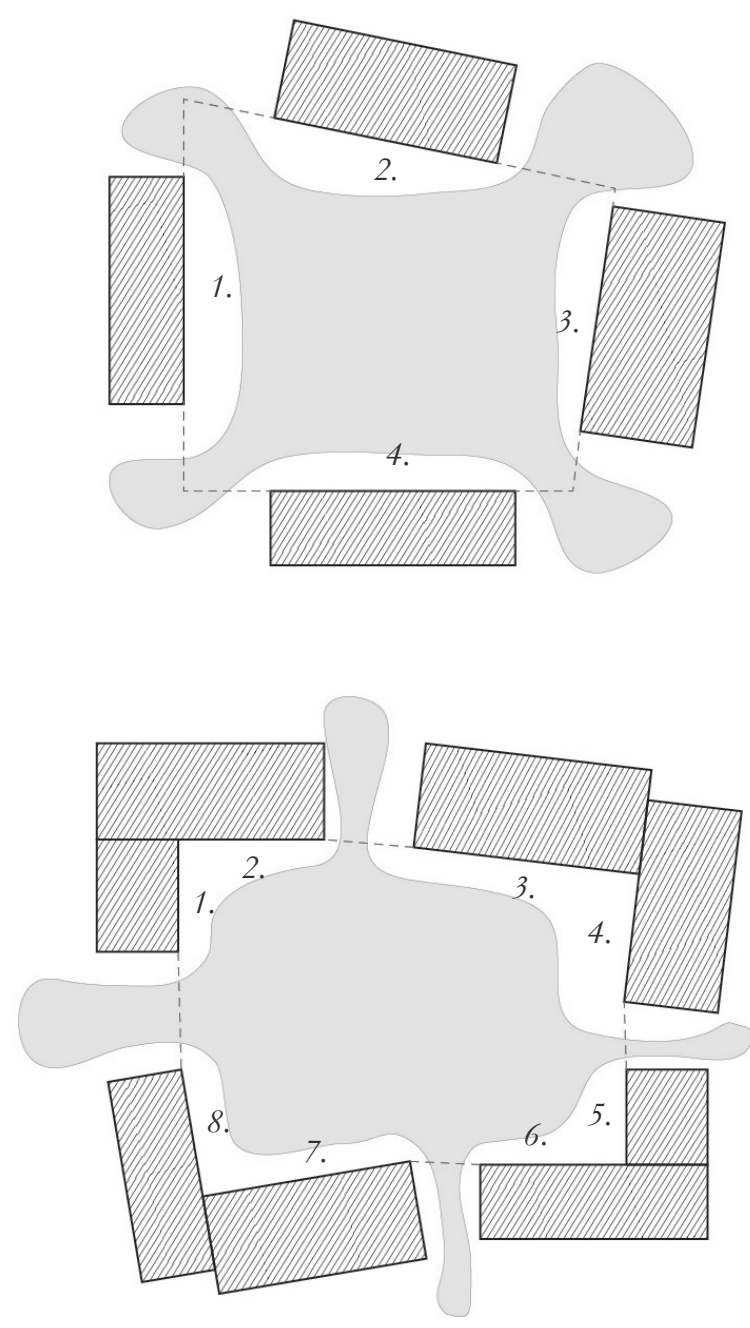

\section{S C A L E}

Large urban areas create a grand feeling making the occupant feel small, less significant, and exposed within the space. Confined spaces create a sense of enclosure and can be used to enhance privacy.

\section{OPEN C O R NER S}

Spaces designed with open corners appear and feel less enclosed for an occupant. The example to the left indicates only 4 internal faces defining the space.

\section{CLOSED CORNERS}

Spaces designed with closed corners create a sense of enclosure. Another example illustrates the number of internal faces defining the space. When corners are closed the faces increase to 8 . This increases an occupants sense of enclosure. 


\section{SENSE OF ENCLOSURE}

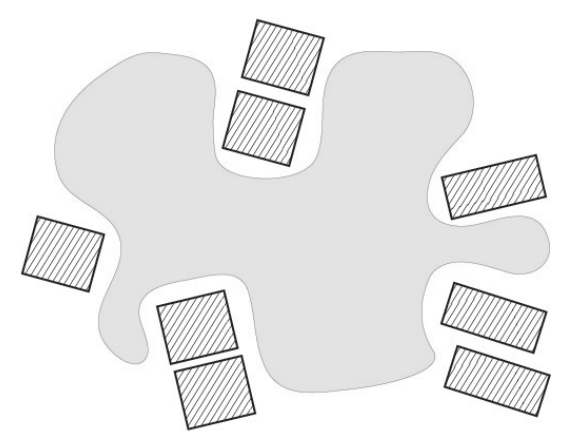

\section{OW ENCLOS UR E}

The space is less identifiable when opened up to a larger scale, has many entrances and has large spaces inbetween. This could be associated to a low-density suburban or rural street where the urban fabric lacks a sense of direction or building grain.

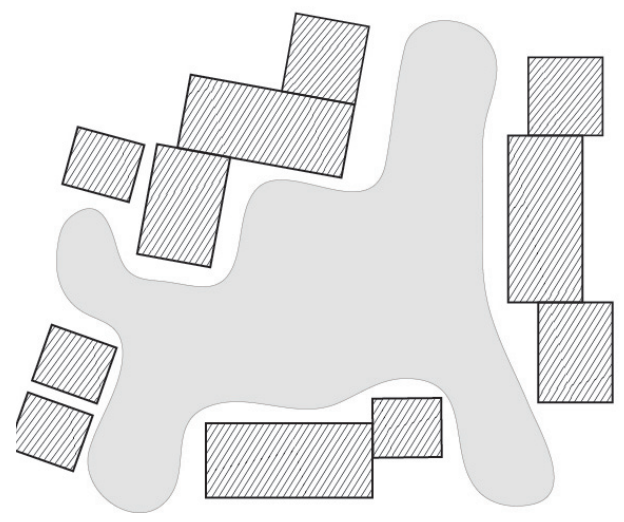

\section{MILD ENCLOS UR E}

The urban fabric becomes denser and more organized. This creates a sense of mild enclosure for an occupant. The user becomes more aware of the boundaries created around them and can understand certain limitations set in place by the built form.

\section{H I G H E N C L O S U R E}

Common in well-defined streets and confined courtyard spaces. Boundaries are clearly defined by the built form. This improves a user's sense of location and directionality. 


\section{URBAN ELEMENTS DEFINING SPACE}
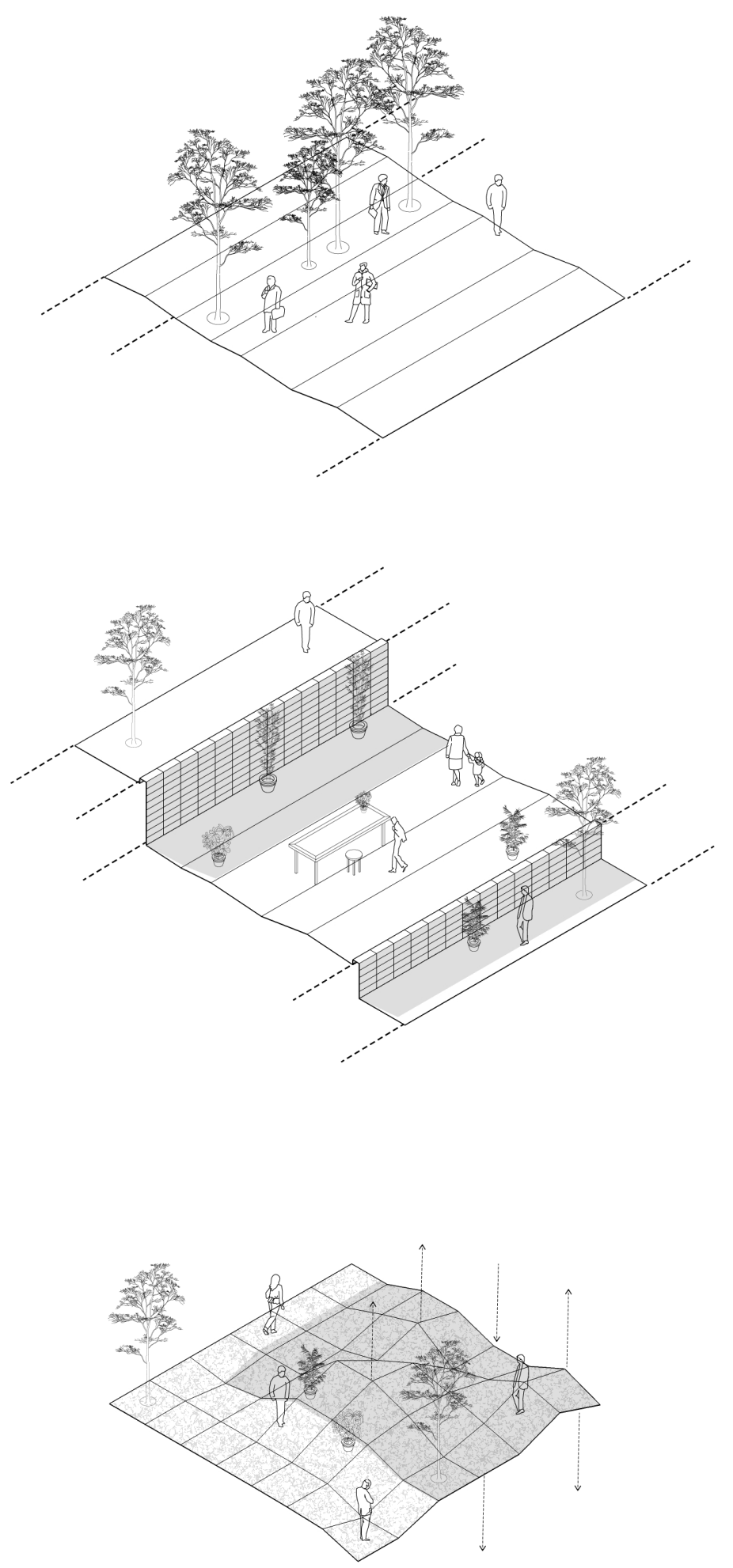

\section{E G E T A T I O N}

Vegetation can define the boundary of a space. Boundaries are more permeable than solid walls as they permits views, light and sound. Tree canopies provide a soft sense of enclosure from above, functioning similar to an awning.

\section{LEVEL C H A N G E S}

Level changes divide the horizontal plane of a space. They add verticality, which defines space as either above or below. Generally a hierarchy in gradients of privacy is created as higher spaces (more private) look down upon the lower levels (less private).

\section{T O P O G R A P H Y}

Natural or artificial changes in landscape help define the boundary of a space. In a public park for example; flatter and more direct areas encourage people to walk while sloped mounds or embankments appear more appealing to sit and occupy. 


\section{BUILT FORM DEFINING SPACE}

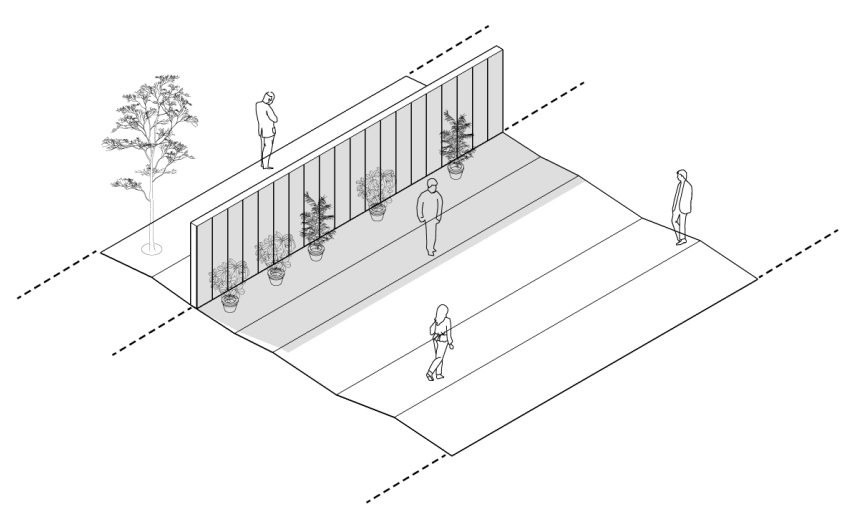

\section{S C R E E N W A L L S}

Create clear definition and boundaries enforcing privacy. Common elements include front or rear yard fences, interior partitions and balcony balustrades. Level of privacy can be adapted by changing permeability of screen, size, height, scale and materiality.

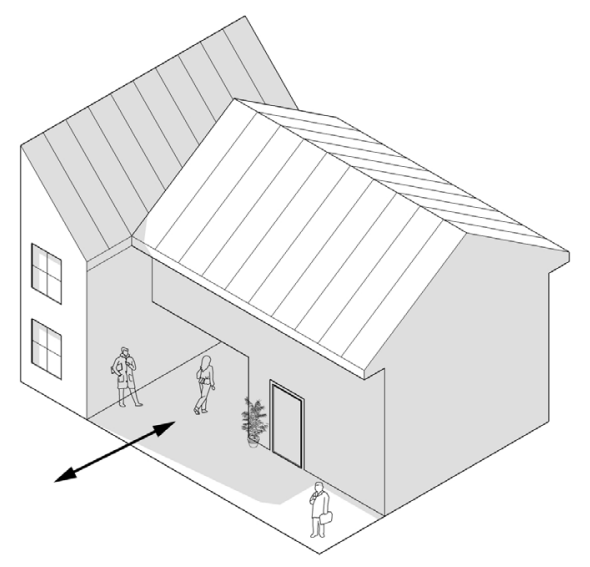

\section{B U I L D I N G FORM}

Openings and building forms are common to create a definition of space. The scale and proportion of an opening provides a clear indication of whether the space feels enclosing or exposed. Building form can influence the privacy of entrances and streets.

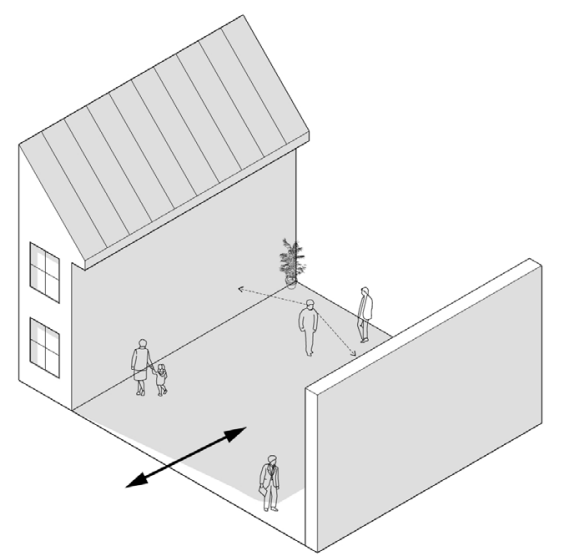

\section{S T REET S}

Scale and proportions of a street is defined by the urban form enclosing it. Streets are important spaces determined by their scale and degree of privacy. They can be large or small, busy or quiet and have different functions depending on how they are designed. 


\section{CONTRASTING SPACES}

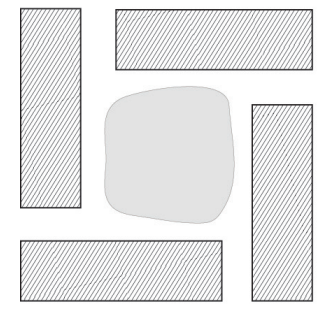

Static Space; courtyard, plaza, foyer, square
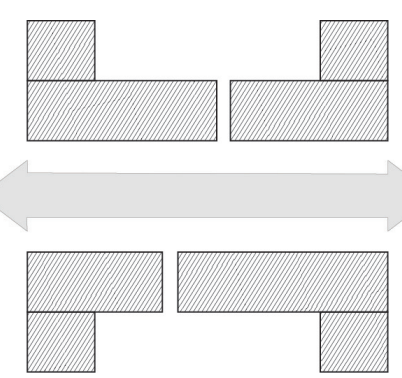

Moving Space; street, pathway, stairs, road

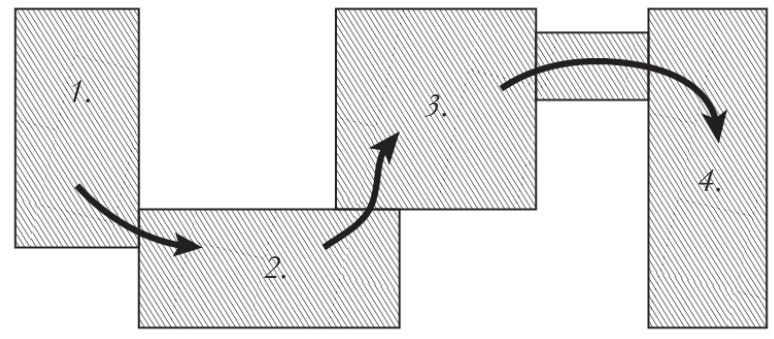

Linked Spaces

\section{O N T R A S T}

Examples to the left show two contrasting spaces. A courtyard designed as a static space for people to occupy compared to a longer and more direct space encouraging movement and thoroughfare.

\section{O N T I N U I T Y}

Continuity of spaces is when one naturally leads to the next and is important when designing networks of spaces. They encourage people to move through designed spaces as intended. This concept can also be applied to linking networks of ecologies.

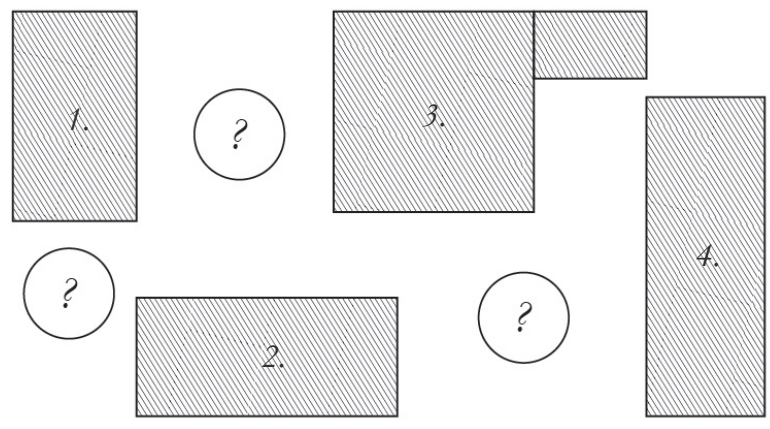

Unlinked Spaces

\section{U N L I N K E D S PACES}

Unrelated spaces lack continuity and contrast. Undefined spaces can become isolated through separation caused by car parks, roads and play areas - any spaces that interfere with the linking of spatial networks. 


\section{TERRITORY \& PRIVACY}

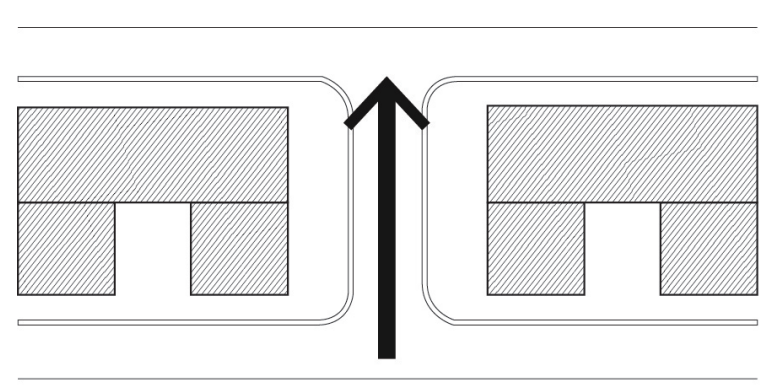

\section{OW E N TR A NCE D E F I N I T I O N}

Entrances that appear less defined encourage use and access by the public. Pedestrians have a detailed view of the space and therefore feel invited, comfortable and less conscious entering from one space to the next.

\section{MILD DEFINITION}

Arrangement of built form is closer together. Defines and limits people entering. Entry remains permitted however it appears more suited for semi-public and semi-private spaces which can deter public.

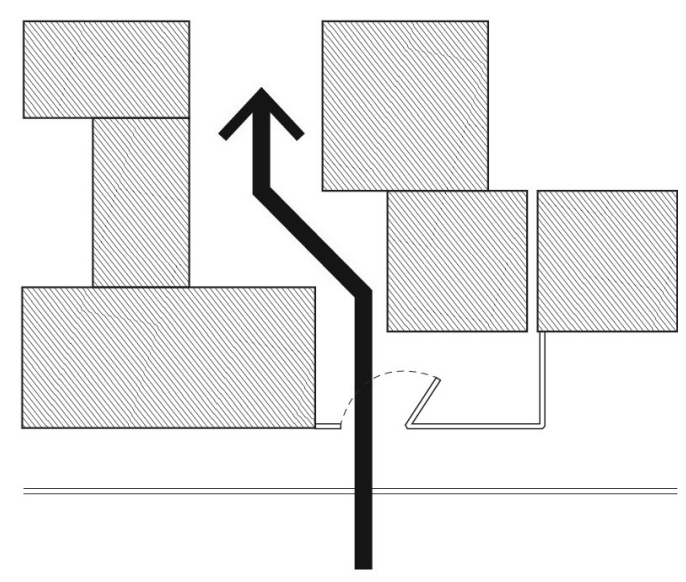

\section{W E L L D EFINE D E N T R A N C E}

Common in residential settings where owners clearly define boundaries between public spaces and privatised territory. Arrangement of dwellings and grain become tighter. Additional fences or gates deter public entry. 


\section{SPATIAL PROPORTION - NARROW}
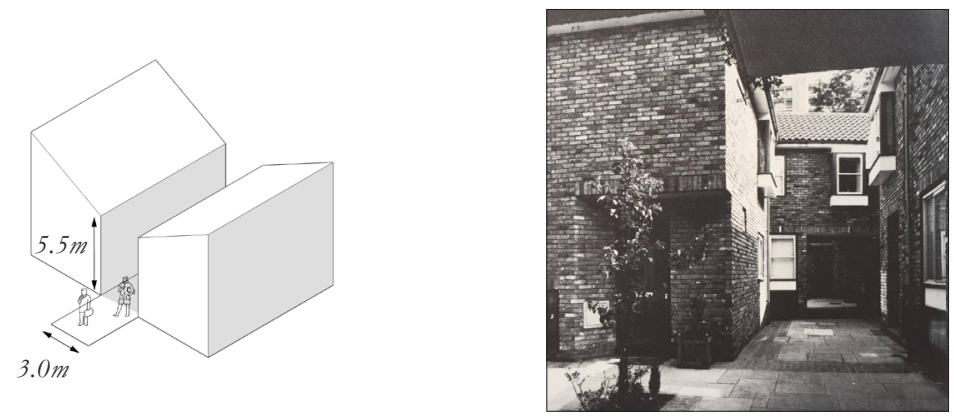

C O N T E M P O R A R Y LONDON MEWS

1.8:1

Height: $5.5 \mathrm{~m} \quad$ Width: $3.0 \mathrm{~m}$

Narrow and very confined, private

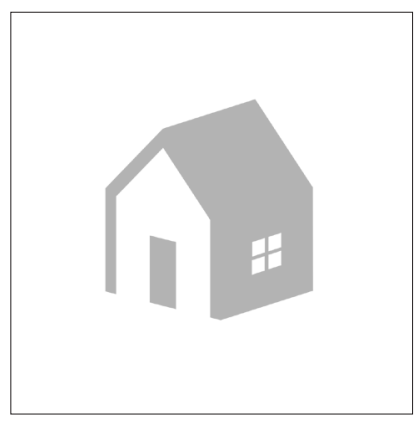

\section{MINIMUM RATIO}

$1: 1$

Height: X Width: X

Suggested minimum height/width ratio by GLC - less feels claustrophobic

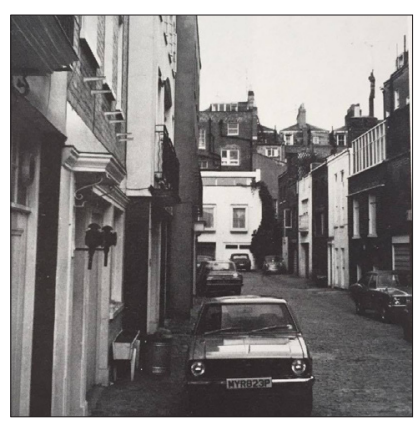

T R A D I T I O N A L LONDON MEWS

$1: 1$

Height: $6.5 \mathrm{~m} \quad$ Width: $6.5 \mathrm{~m}$ Mildly confined, semi private

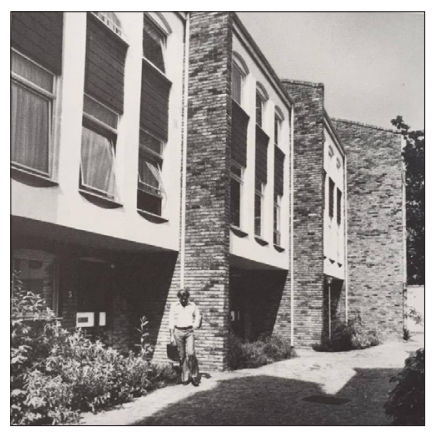

C O N T E M P O R A R Y LONDON MEWS

$1: 1.2$

Height: $7.6 \mathrm{~m} \& 5.2 \mathrm{~m}$ Width: $9.2 \mathrm{~m}$ Mildly confined, semi private 


\section{S PATIAL PROPORTION - WIDE}
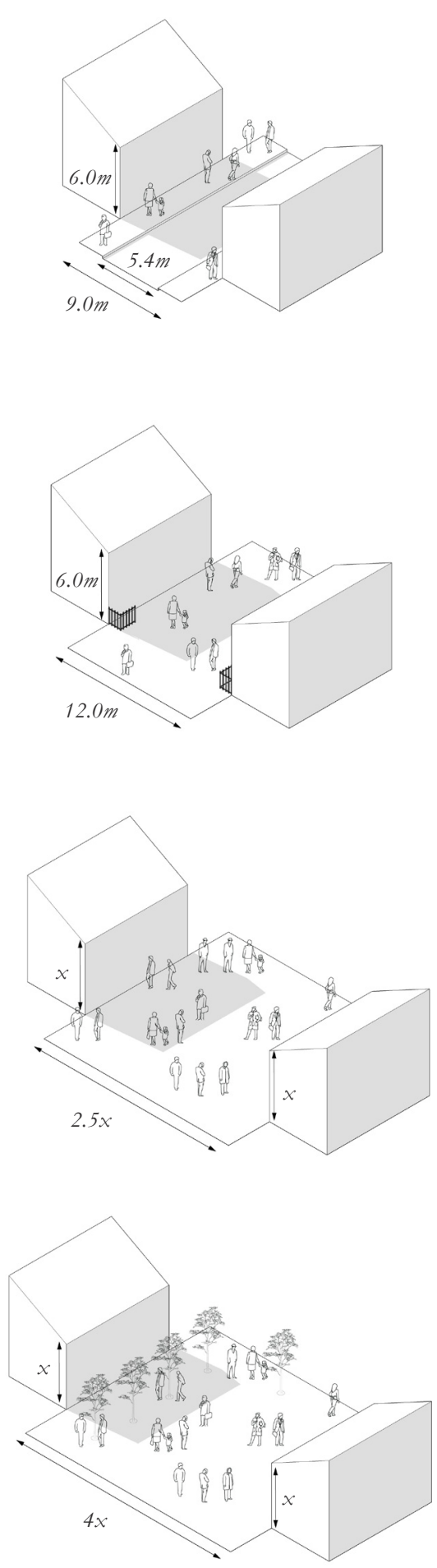
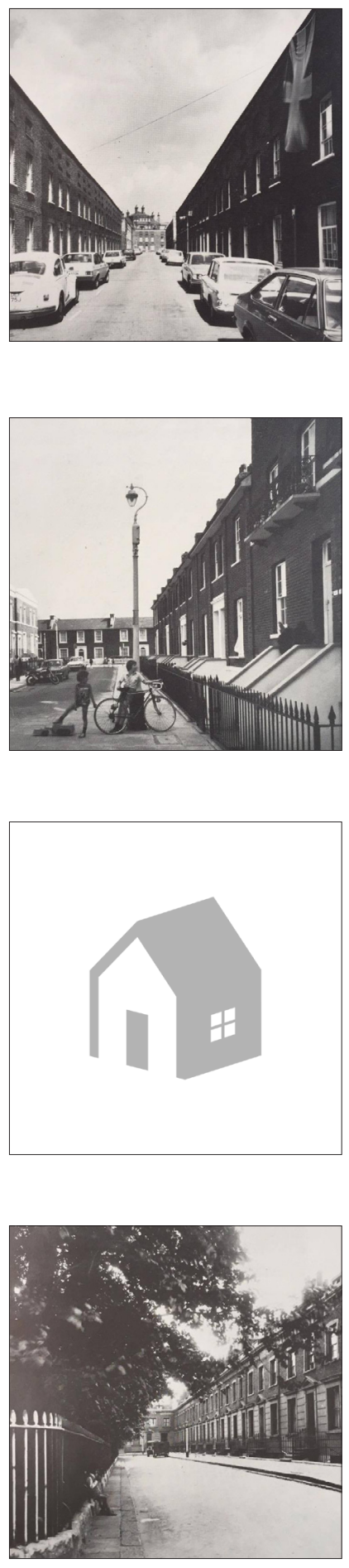

T R A D I T I O N A L COURTYARD

$1: 4$

Height: X Width: 4X

Extremely wide, public space

T R A D I T I O N A L

LONDON TERRACE

$1: 1.5$

Height: $6.0 \mathrm{~m} \quad$ Width: $9.0 \mathrm{~m}$

Wide with openess to sky, semi public

T R A D I T I O N A L

LONDON TERRACE

$1: 2$

Height: $6.0 \mathrm{~m} \quad$ Width: $12.0 \mathrm{~m}$

Considerably wide, semi public

\section{MAXIMUM RATIO}

$1: 2.5$

Height: X Width: $2.5 \mathrm{X}$

Suggested maximum height/width ratio by GLC - greater feels too exposed 


\section{HARD \& SOFT EDGES}

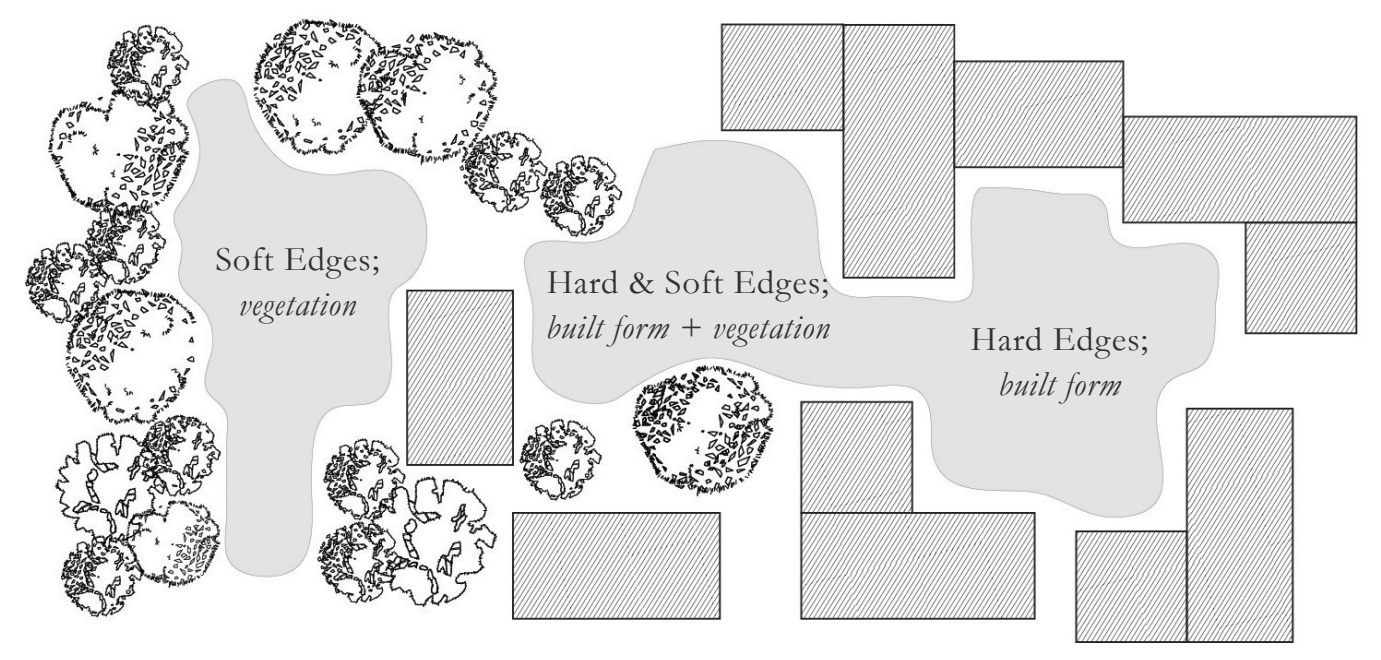

Hard and soft edges create a visual variety, interest and change of character of a space while keeping contrast and retaining spatial definition.

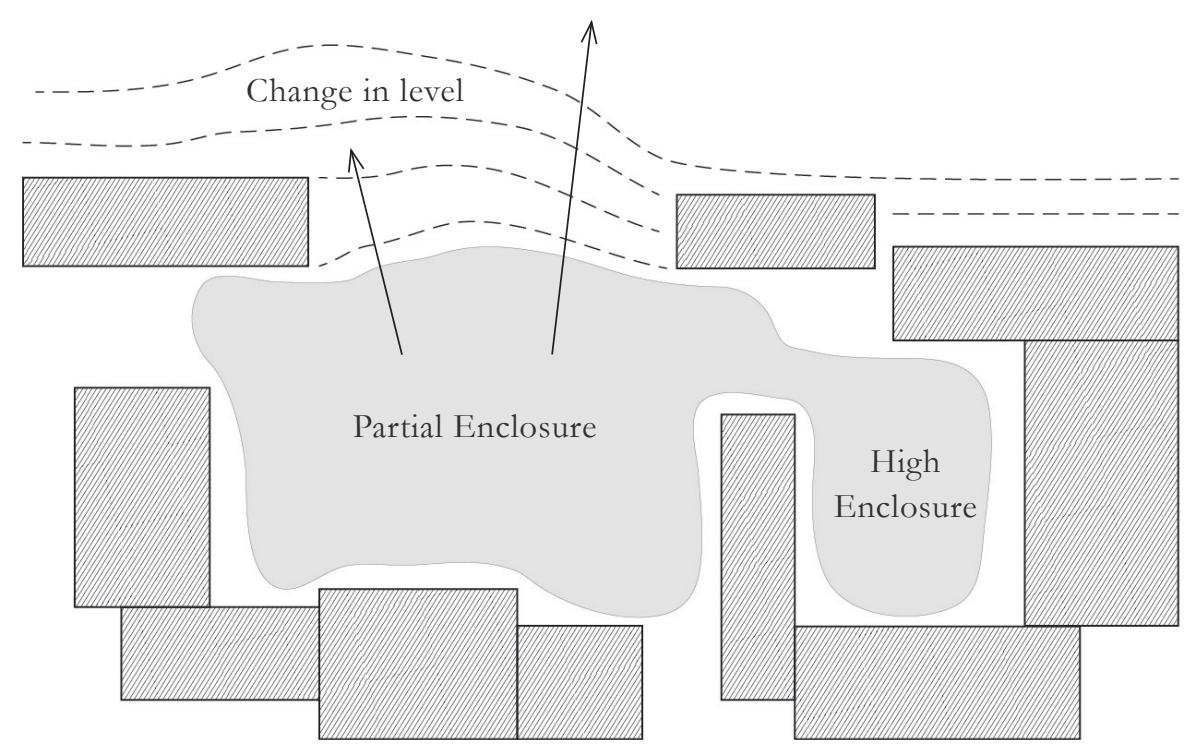

Other elements such as change in level can be used to define a space without entirely enclosing it. A subtle change in levels can become an alternative to enclosing a space with built form. 


\title{
SPATIAL PARAMETERS REFLECTION
}

\author{
I N S UMMARY
}

Determining the spatial characteristics of successful spaces between buildings can inform the design of future ones in ways that will stimulate the human senses. Human reactions and feelings are related to the observable characteristics and qualities of a given space, whether it be wide or narrow, large or small, high or low. (Gehl, Jan)

Sense of enclosure and the proximity to which each dwelling is arranged to another is an important consideration. When working with an urban consolidation scheme the main focus is to provide a more densely populated floor area with additional built form. Densely populated urban environment generally create a more confined and enclosed space for people down at street level. If managed well these more enclosed and privatized areas can be contrasted with larger spaces more suited to a public realm. This creates positive contrasts leading to more intriguing and well-designed networks of spaces.

Smaller groupings of dwellings tend to create a feeling of intimacy, protection and security, which helps to define a resident's territorial boundary. People are one of the most important elements of a space and therefore the spaces should be scaled to their use.

Using a combination of hard and soft edges to create a visual variety in spaces becomes an opportunity as the intensification scheme looks to increase built form while integrating the natural ecologies of a site. The strategic arrangement of built form and additional planting can help structure and enclose desired public spaces while providing an interesting contrast in character through hard and soft edges. 


\title{
NATURAL ECOLOGY
}

\author{
Nature visible in cities today, every landform, bydrologic feature, or plant life \\ is to some degree shaped by the life history of that point on Earth' - Timothy \\ Beatley
}

The analysis began with an overview of the natural ecologies existing on the site. From this simple strategies for strengthening and integrating these ecologies alongside urban densification were devised.

The subsequent design concepts integrate ecological systems to complement, add vitality to and improve the quality of outdoor spaces and the public realm.

They suggest how urban densification can incorporate ways to regenerate the existing ecological networks, nurture vegetated slopes and the wider natural systems of Wellington's town belt and parkland. 

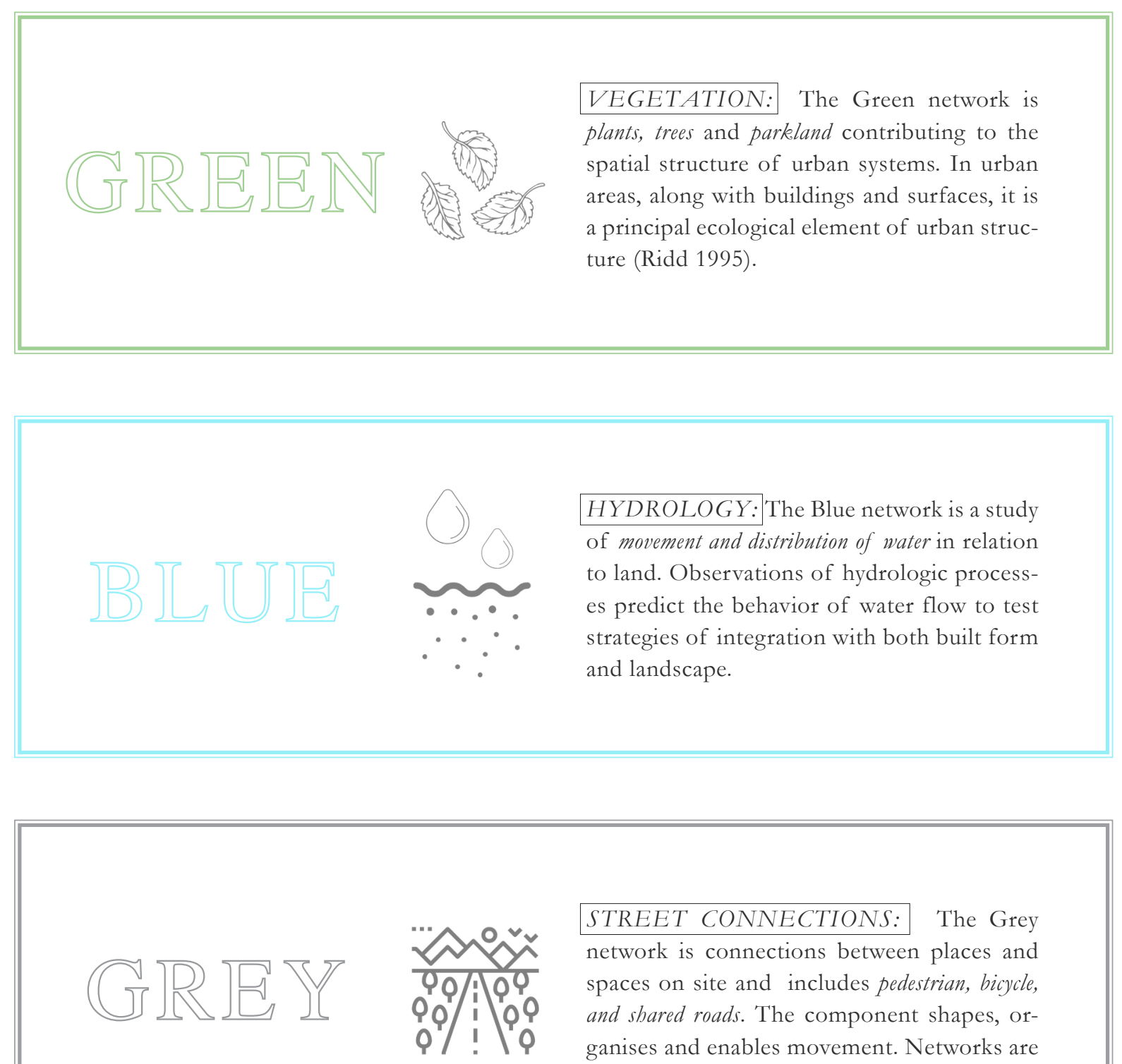

STREET CONNECTIONS: The Grey network is connections between places and spaces on site and includes pedestrian, bicycle, and shared roads. The component shapes, organises and enables movement. Networks are defined by size, scale and functionality.

The following ecology analysis section identifies the inherent qualities embedded in the site; an important first step in creating positive links between the new organization of built form and the existing landscape. The natural ecologies researched in this section have been refined into the three categories of green, blue and grey networks - relating to vegetation, hydrology and street connections respectively. 


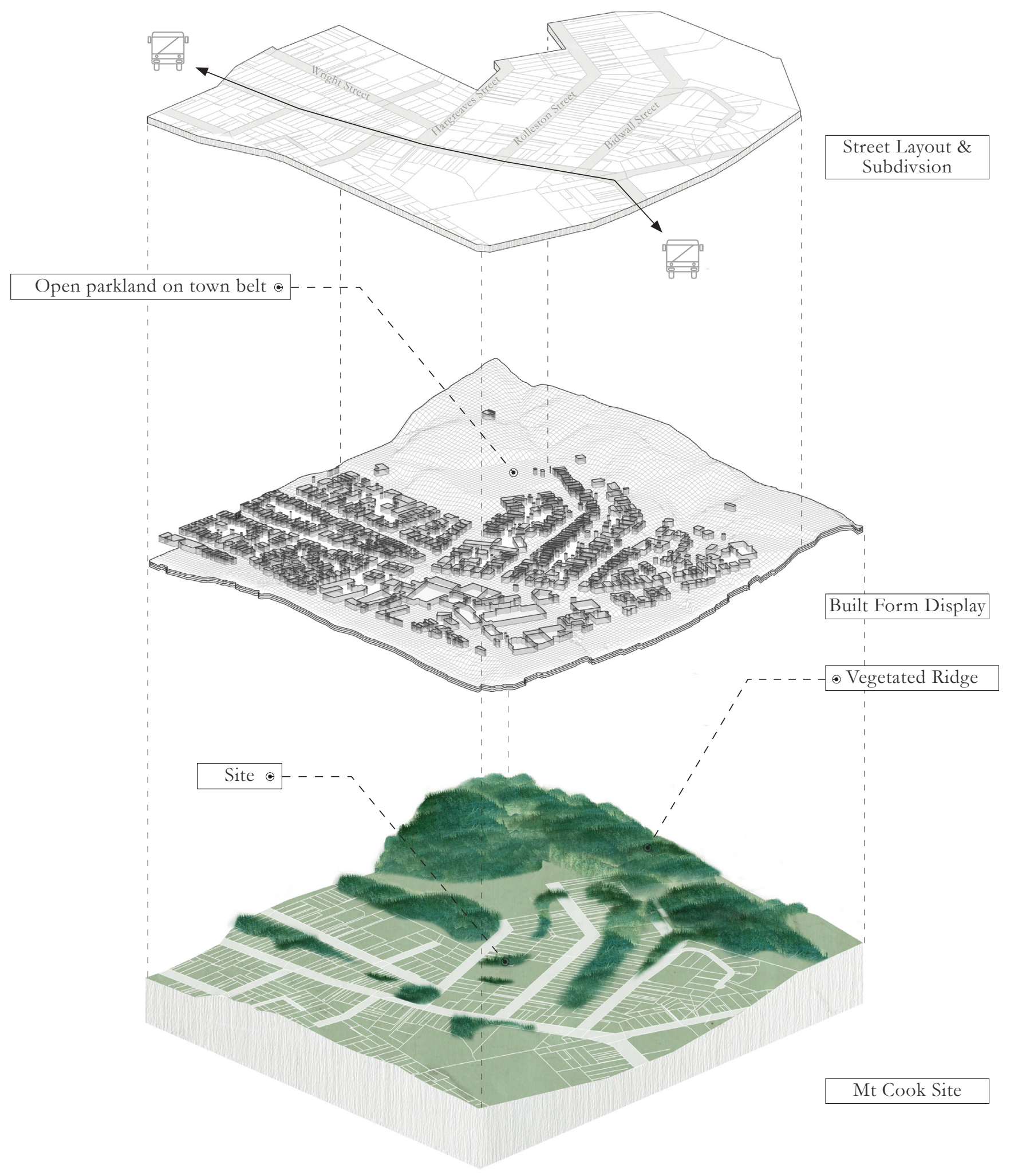

E C O L O G A X O G E Y 


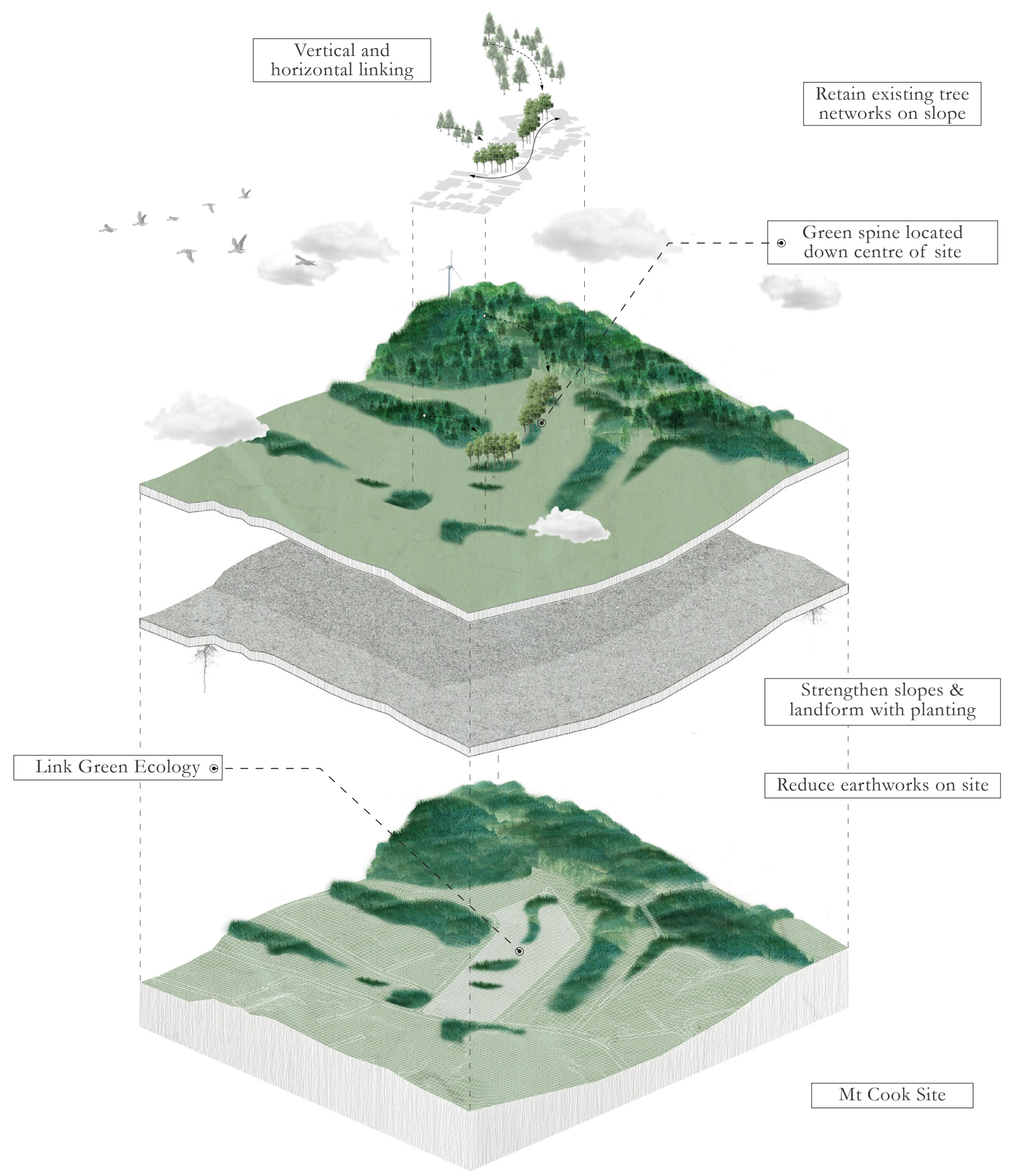

ECOLOG Y A X GREEN 


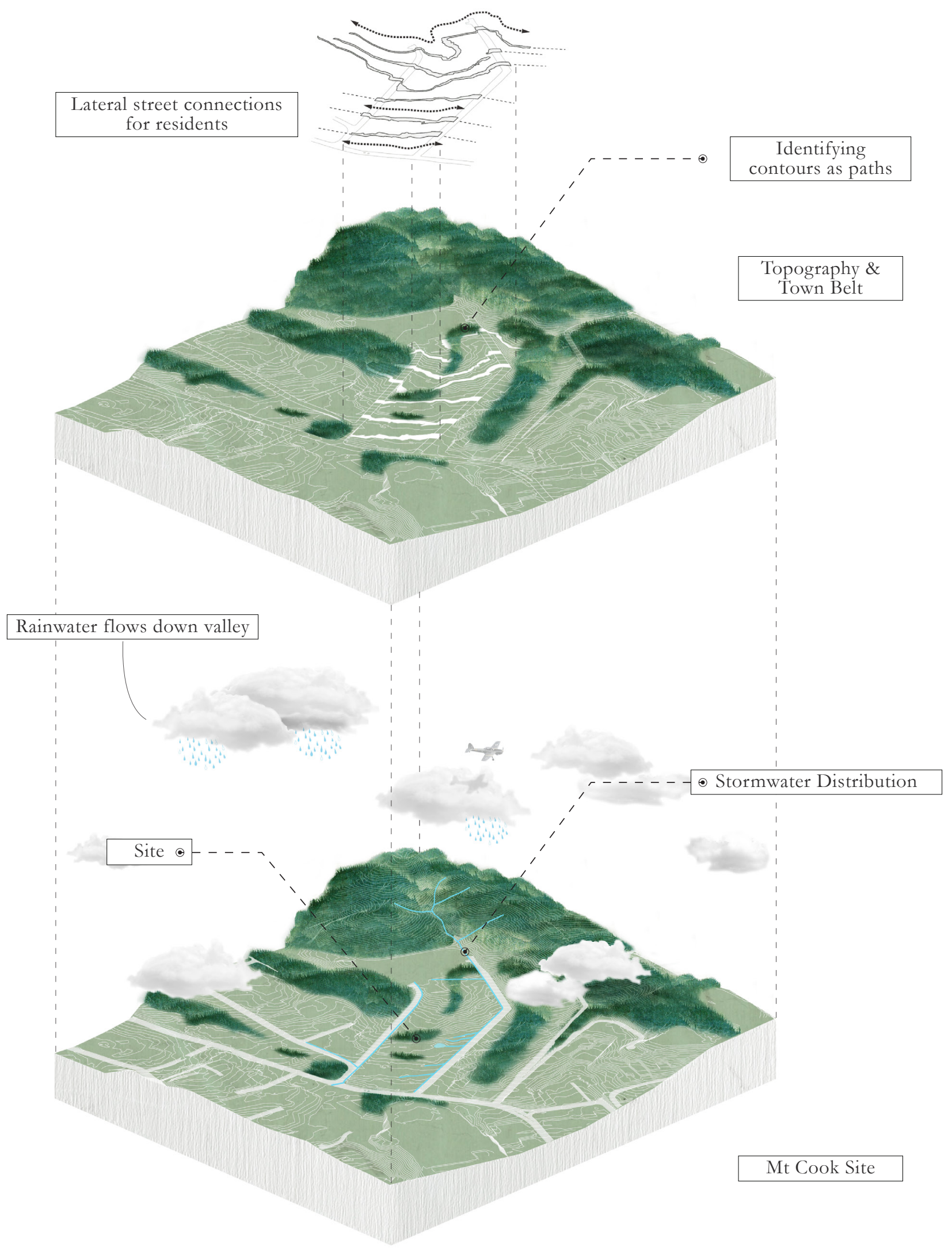

E C O L OG Y A O B L UE 


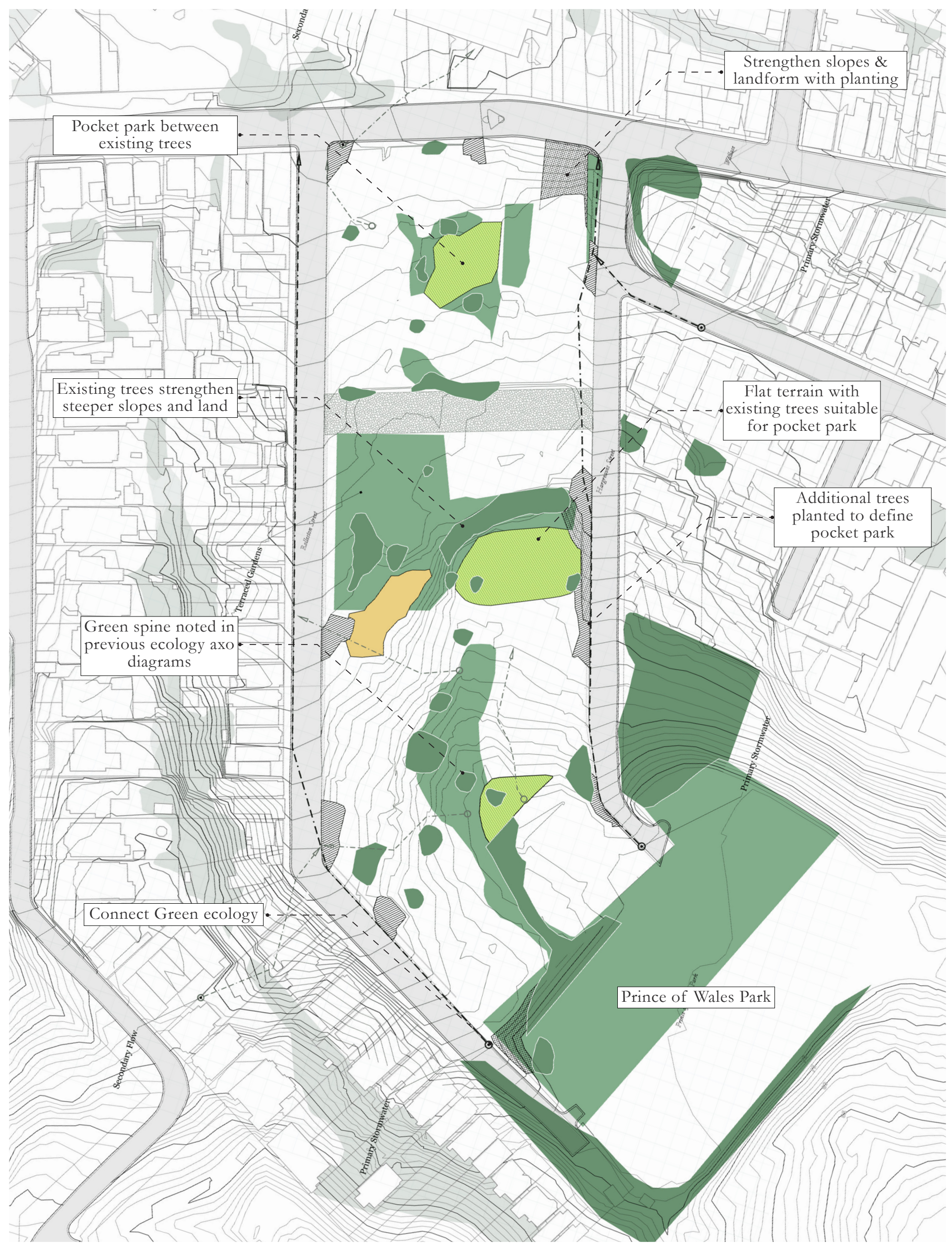




\title{
GREEN NET W OR K
}

\author{
VE G E T A T I O N
}

This Green Network analysis is a study of existing vegetation and where proposed planting would be appropriate to take place. The existing vegetation is categorized into both low and high planting. The study also concludes where areas for public open green space would be suitable.

Clearly denoted on the map is a strong vegetated spine stemming from the top of the site at the Prince of Wales Park down through to the centre of the site where it connects to a more scattered groupings of vegetation. The central green spine is a strong ecological component that provides a unique link vertically through the site while strengthening the sloping landform.

Decisions on additional planting was based on;

o Linking existing vegetation into stronger and more resilient networks

o Framing public open green spaces with vegetated to help define boundaries

o Strengthen steep areas of topography to improve resilience of landform

Decisions on locating public open green space was based on;

o Proximity to existing vegetation and green ecology

o On plateaus in landform as they provide flatter areas for the public to occupy

o On areas of land that would provide intriguing views down and across the site

o Staggering open green space as pocket parks that pedestrians pass through

$<$

Figure 90 // Ecology Site Map; green networks 


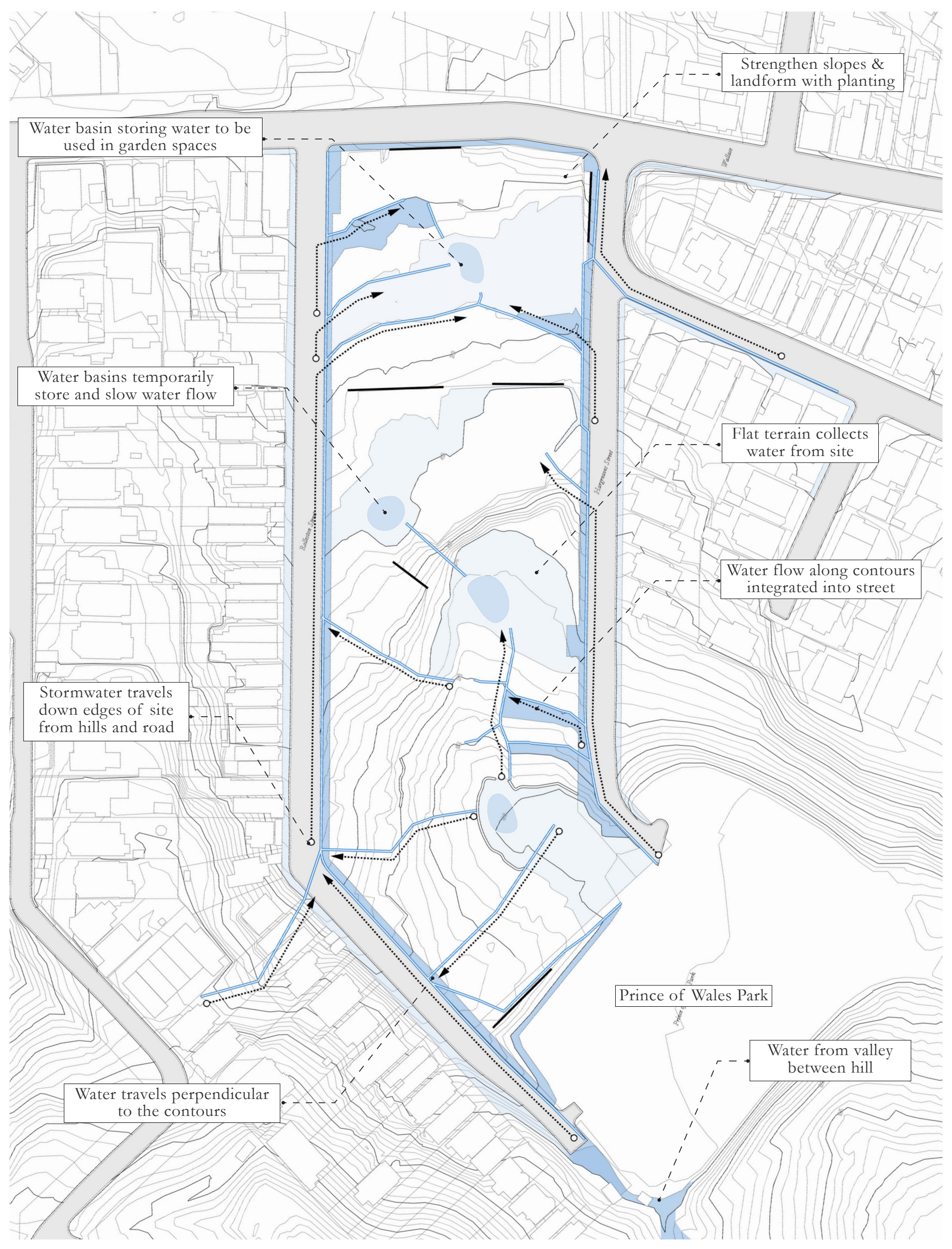




\title{
B L UE NET W ORK
}

\author{
H Y D R O L O G Y
}

The Blue Network analysis is a study of movement and distribution of water in relation to the natural topography. GIS maps and $3 \mathrm{~d}$ modelling assisted with informing where stormwater and rainwater would move through the site. Demonstrated on the previous page, the flow chart maps water flowing at right angles to the contour lines. Only major water bodies are mapped and are located in areas of the landscape where;

o Topography converges into valley and gully shaped landforms

o Topography becomes steeper

o Topography has a constant direction of slope fall meaning water flow does not disperse

o Down the edges of the site towards gutters

$<$

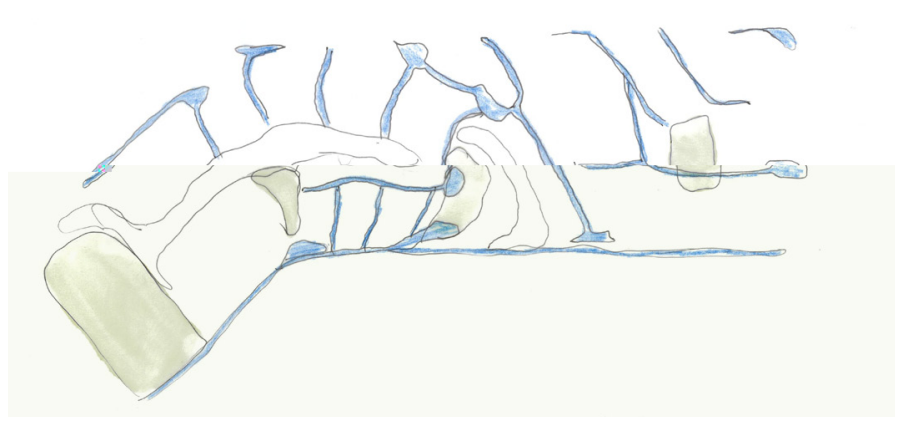




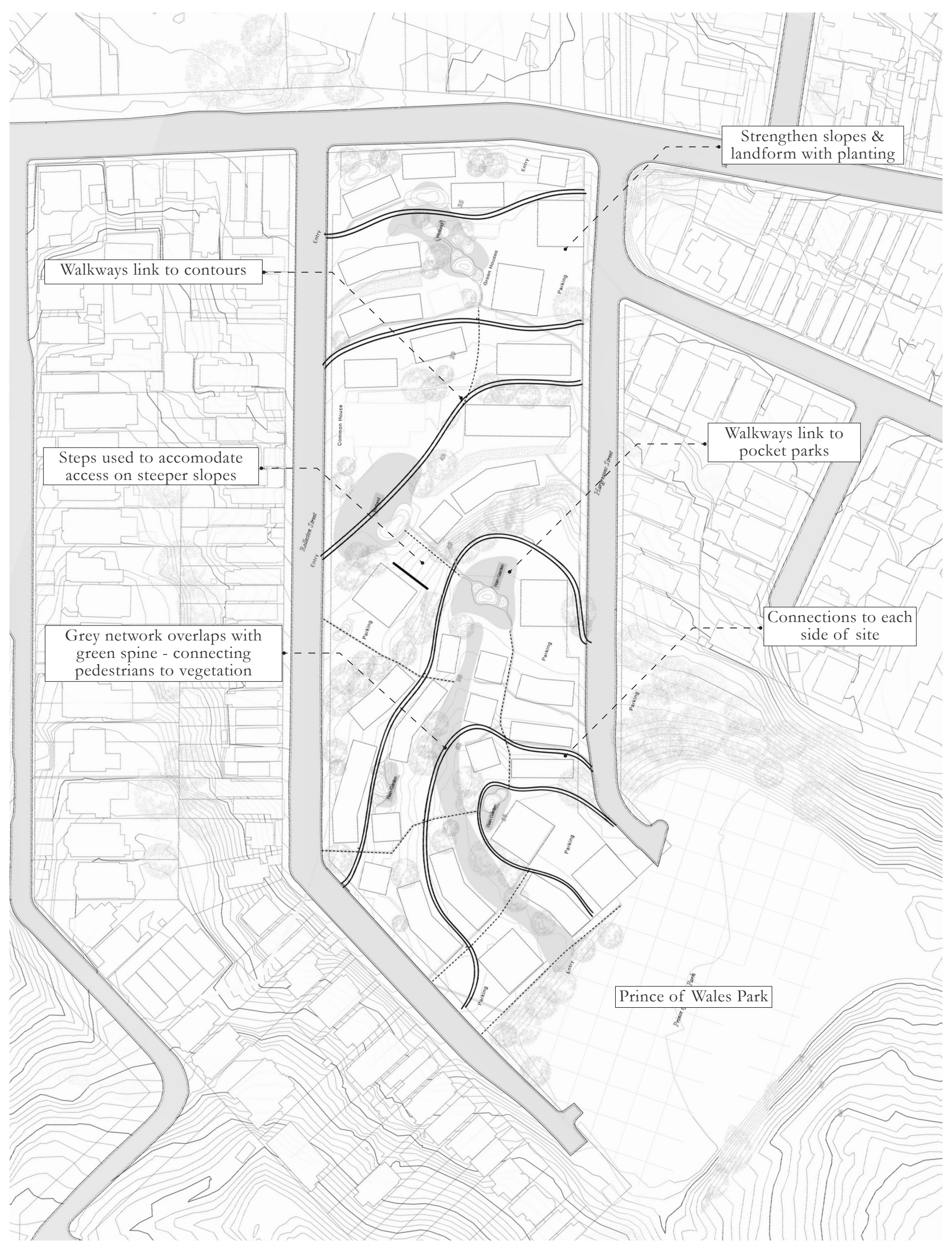




\title{
GR E Y N E T W O R K
}

\author{
STREET CONNECTIONS
}

This analysis consists of iterative design work to establish how people can move across the sloped topography. The design goals were to create an efficient and beautiful response to moving around the landforms and connecting residential streets to public areas on the site. Process models displayed below demonstrate iterations of providing lateral links across the site. The most successful results were realized when;

o Walkways were aligned with contour datum lines

o A path connected to each side of the site improve accessibility

o Connections at consistent datum levels reduce land excavation

o Steep inclines utilize steps

$<$

Figure 93 // Ecology Site Map; grey networks Figure 94 // 1:200 Model; site circulation iterative process
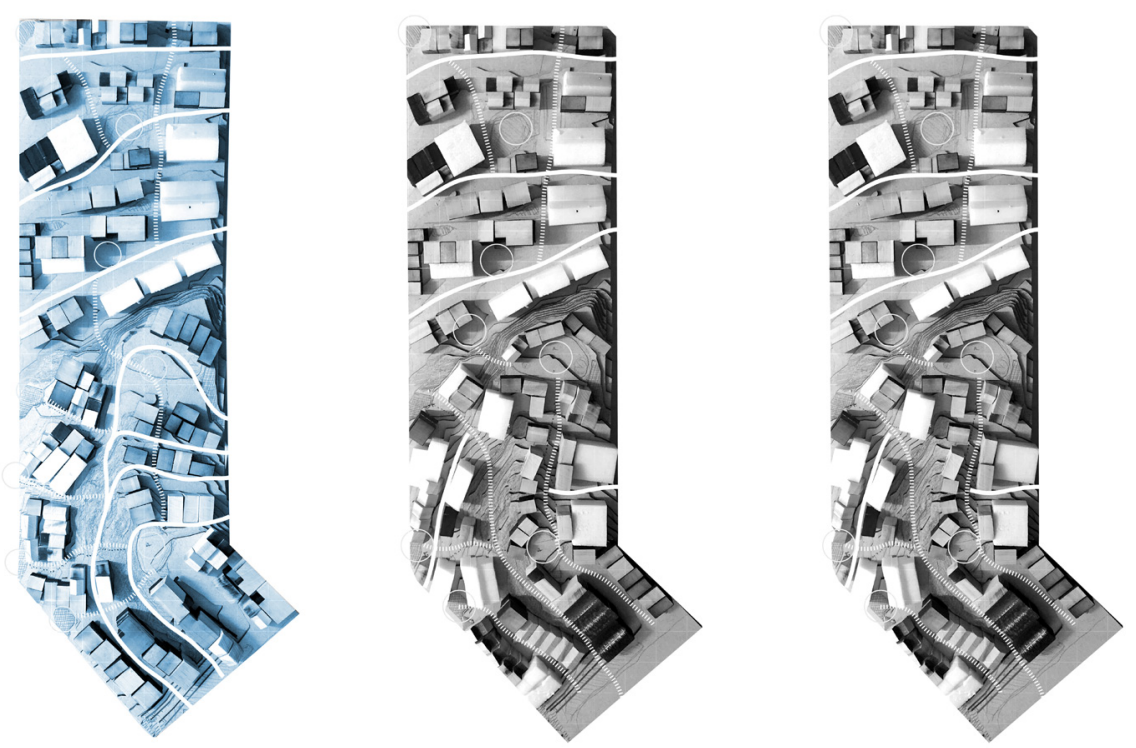


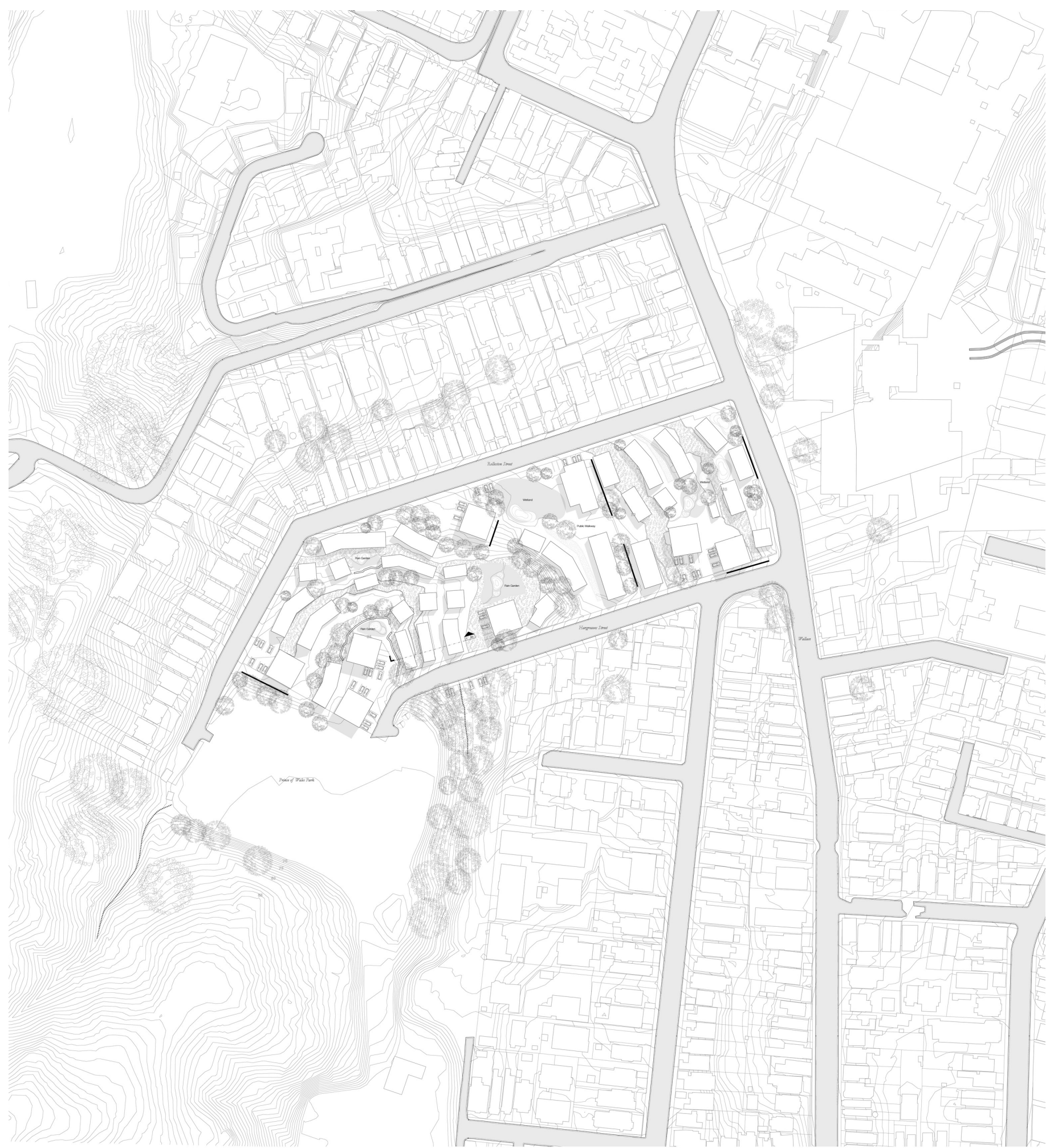

Following on from the natural ecology research a new layout of built form was tested. The layout attempted to integrate previous ecology concepts. The iteration was discussed in a design review and the following feedback was noted;

$\Lambda$

Figure 95 // Site Aerial; iteration of built form and ecologies 


\section{SITE PLAN ITER ATION}

BUILTFORM + INTEGRATED ECOLOGIES

\section{FEEDBACK}

The design requires more extreme contrast of spaces, large and small

Pocket parks are too large and undefined

Bottom of the site could be made more permeable for the public

Top part of site might be more closed off.

Define the major and minor paths across the site

Define the major and minor pocket parks

Clearer hierarchy in site plan of typologies

Variety of typologies needs development

Utilize hardscape vs vegetated areas / landscape

Greater attachments in built form, then create cuts and breaks

Too many small pieces, more attached dwellings 


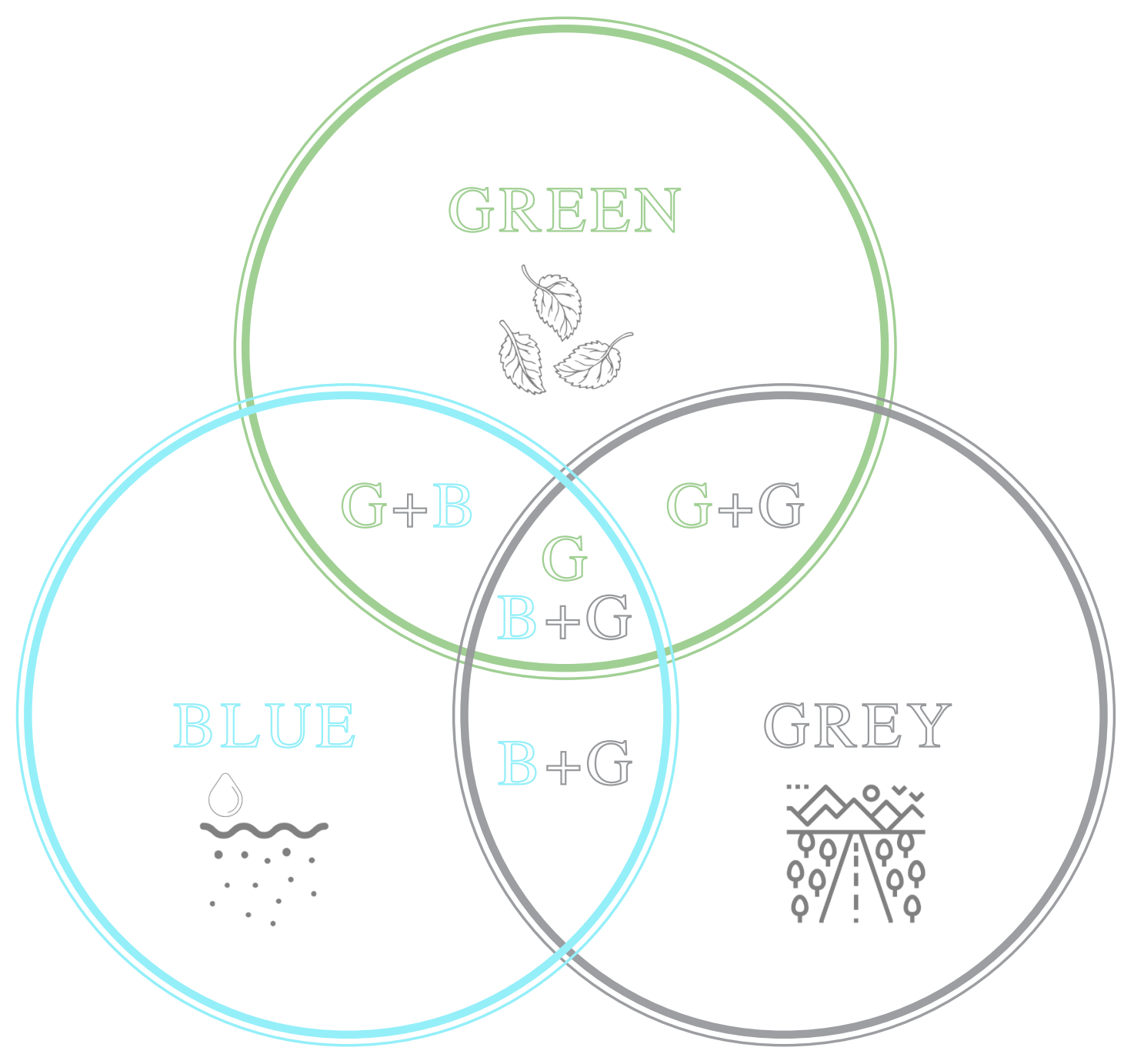




\title{
NATURAL ECOLOGY REFLECTION
}

\author{
I N S UMMARY
}

\begin{abstract}
When considering urban densification the new arrangement of built form around existing ecological networks can achieve a more sensitive response to the site. Allowing natural ecologies to remain on the site creates opportunities to benefit the urban densification, as they are the component that contributes the quality of an urban environment. (Bradshaw \& Bekoff) As most people are now living in towns and cities there is a requirement for urban dwellers to seek out interactions with nature by engaging in activities such as visiting urban green space. Encouraging natural ecologies to be retained and strengthened means a quality urban environment can be achieved which is localised for dwellers.
\end{abstract}

Key design opportunities attained from the ecology studies include;

o Street networks and pathways that orientate with natural contours of site

o Form new relationships between ecological networks and site topography

o Natural ecologies support existing urban green space

o Regenerate existing ecological networks to nuture vegetated slopes

o Ecology networks are mutually benefited and strengthened when combined with one another.

$<$

Figure 96= // Ecology Diagram; blue, green, grey ecology overlap 
4 


\title{
F I N A L DES I G N
}

\author{
Chapter containing a visual and written documentation \\ of the final design response. Also included is the final \\ conclusion and critical reflection the thesis.
}




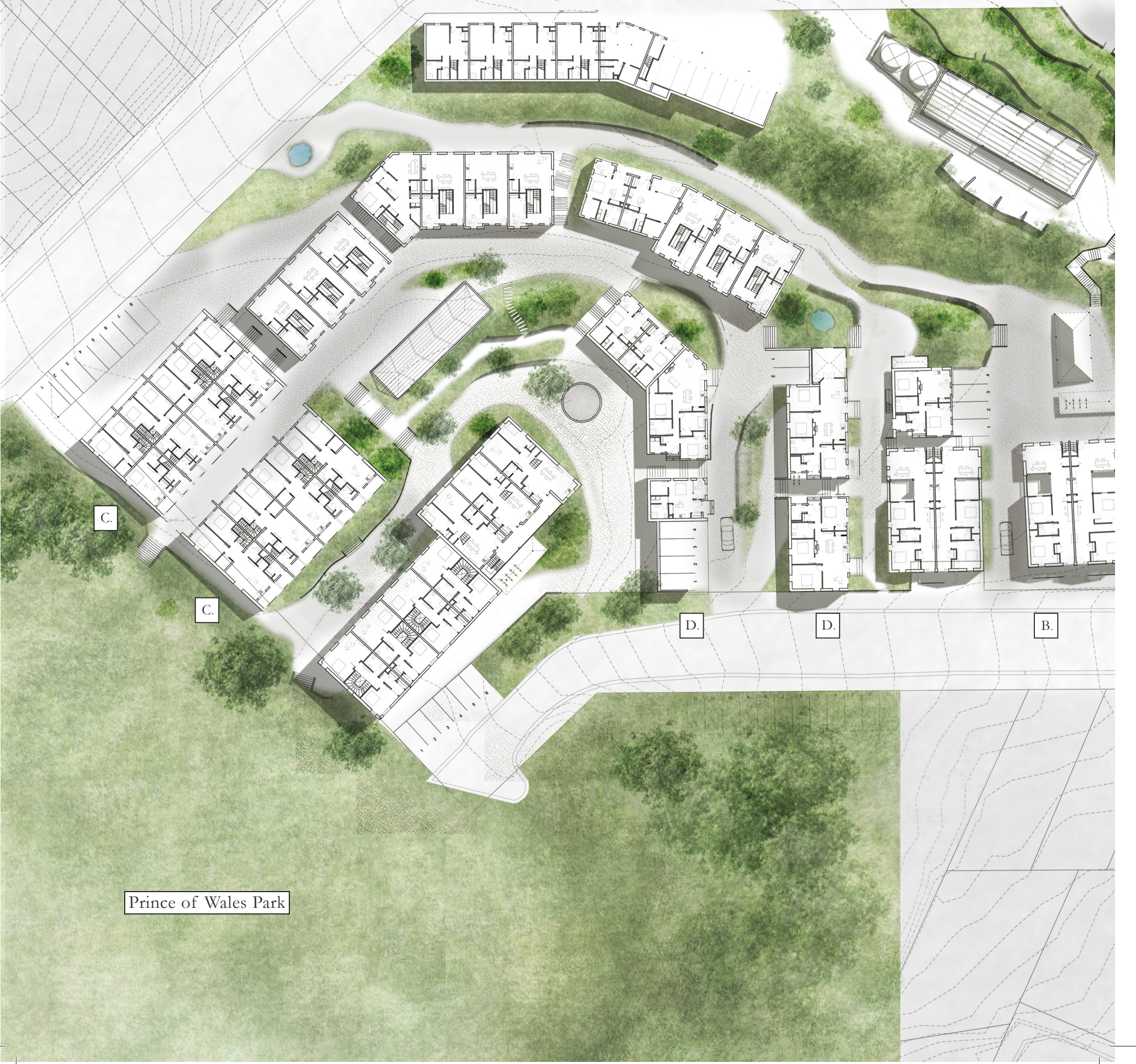



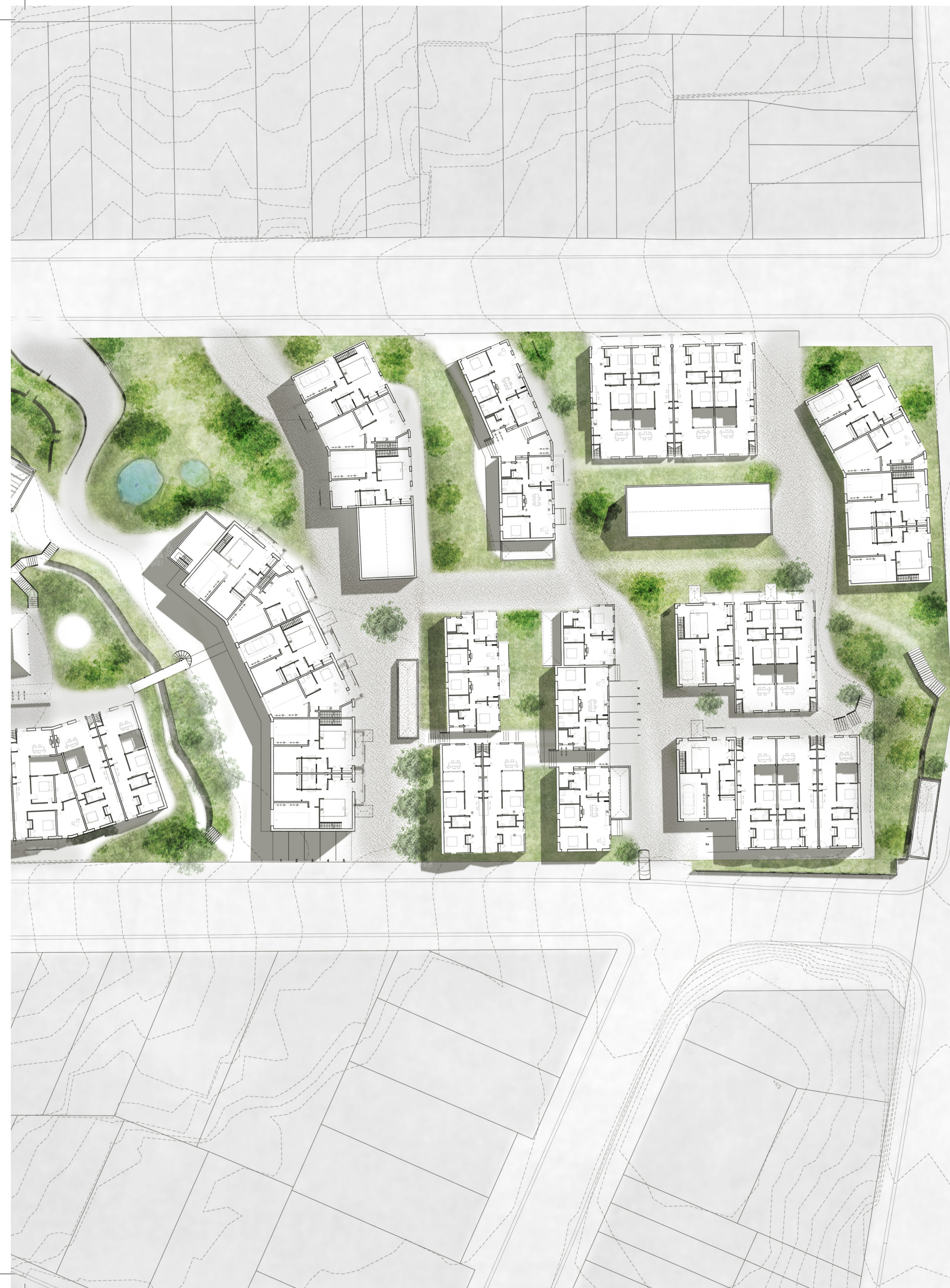

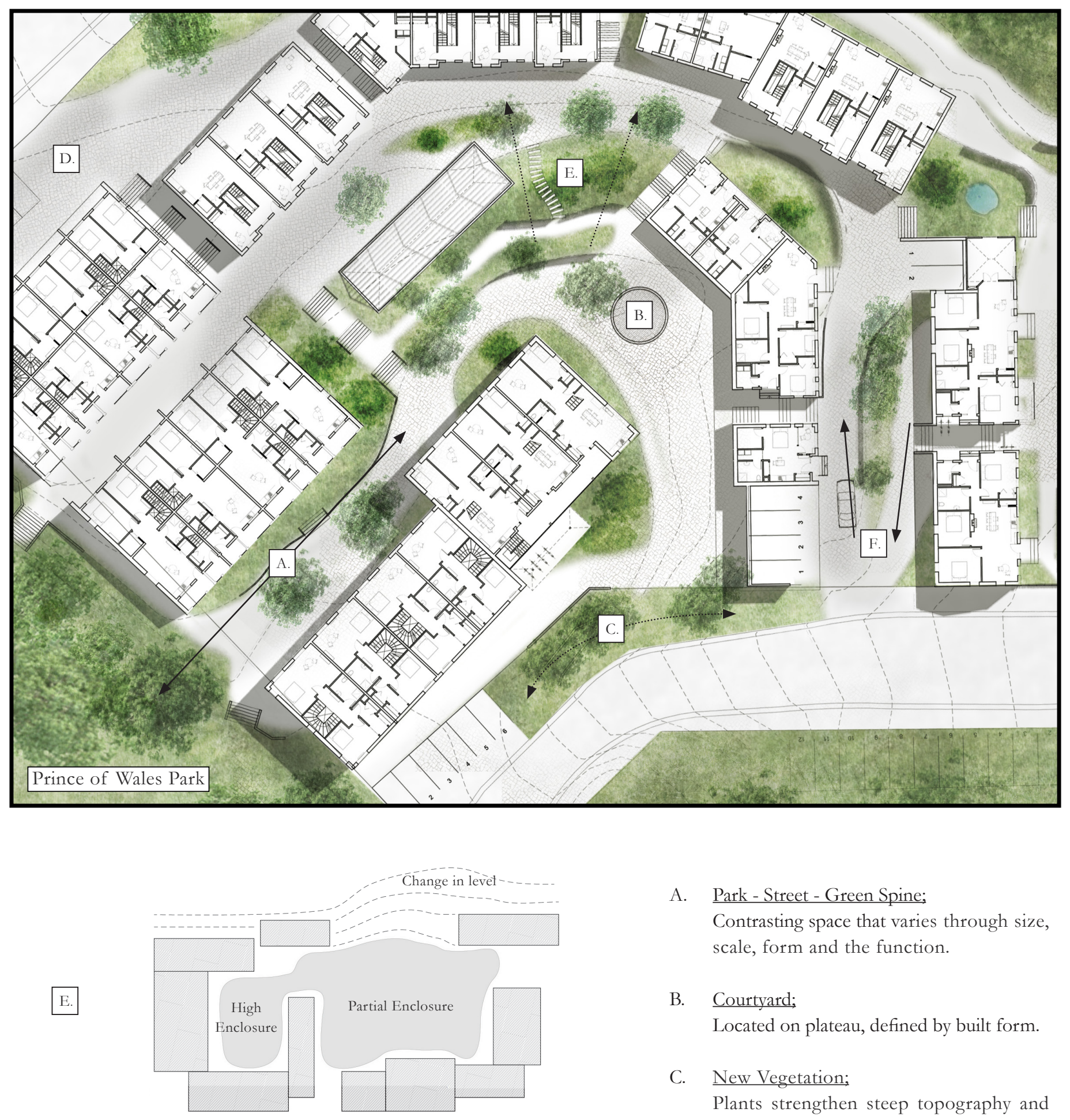

A. Park - Street - Green Spine;

Contrasting space that varies through size, scale, form and the function.

B. Courtyard;

Located on plateau, defined by built form.

C. New Vegetation;

Plants strengthen steep topography and provide privacy from street.

D. Vehicle Parking;

Resident parking located at perimeter.

E. Terraced Garden;

Change in level evokes partial enclosure and encourages pedestrian movement. 


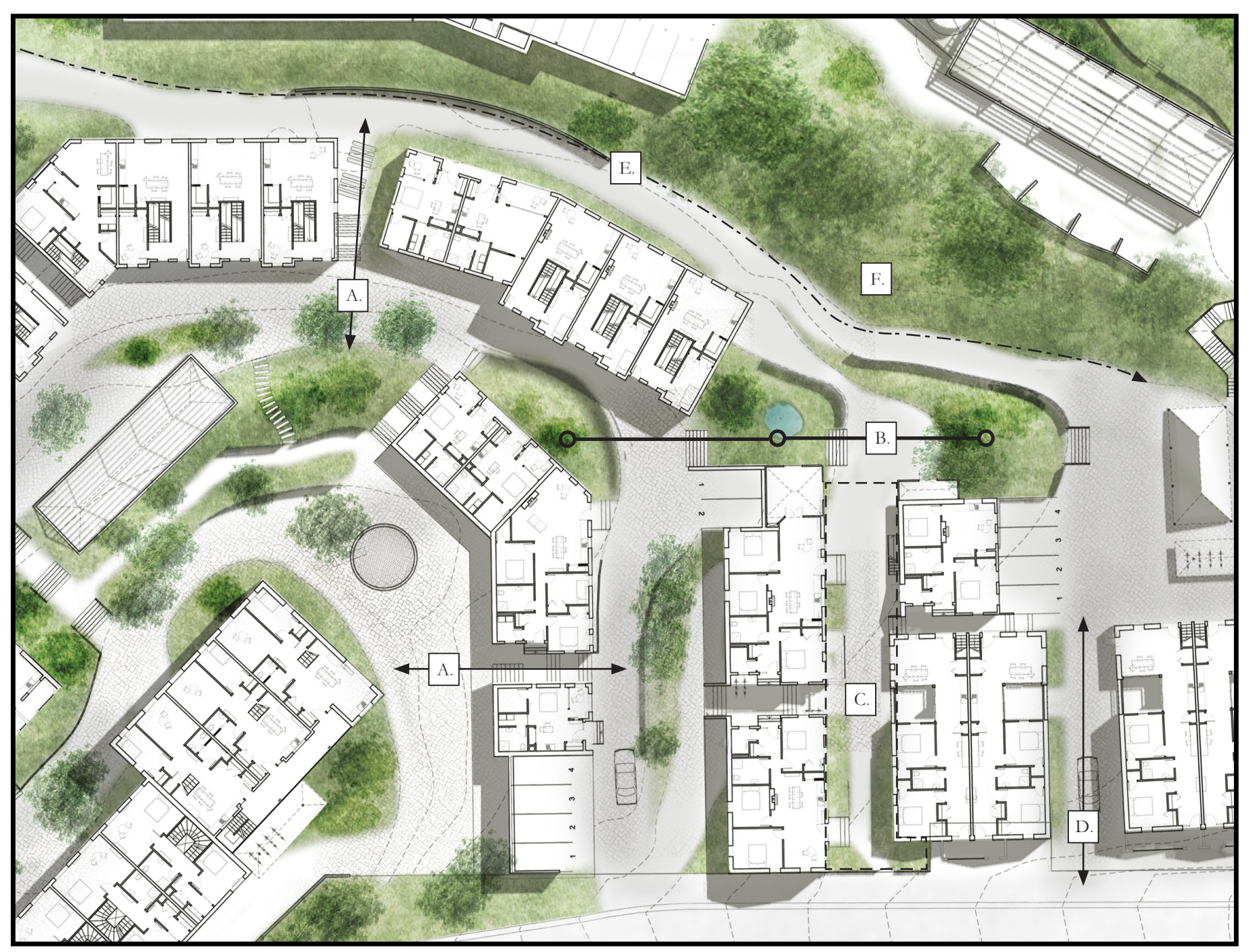

B.

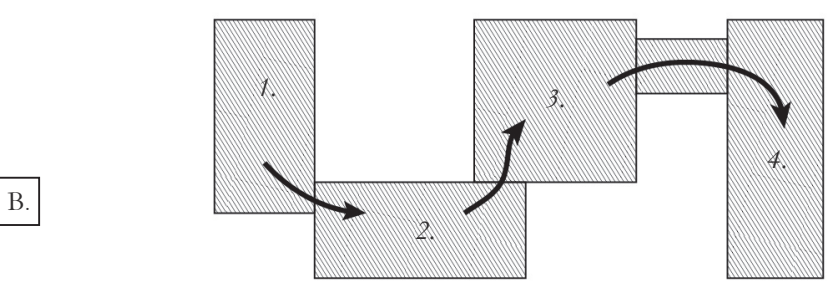

Linked Spaces

B.

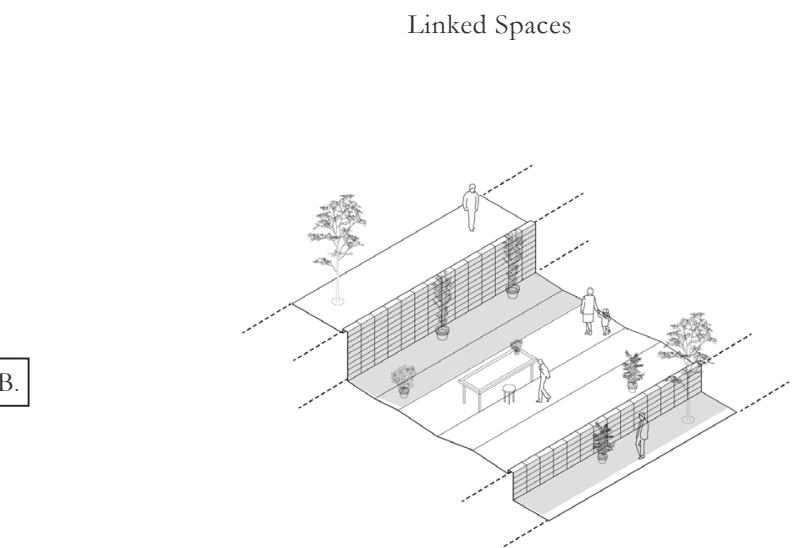

A. Steps between housing;

Narrow stairwells contrast to wider paths.

B. Terraced Gardens;

Gardens step down topography to linking to lateral streets and hydrology.

C. Private Gardens;

Private outdoor space with direct link to dwellings. Seperated from public realm.

D. Shared Road;

Access for cars and pedestrians.

E. Ecological Walkway;

Integrated with topography.

F. Green Ecology;

Vegetation links with walkway. 

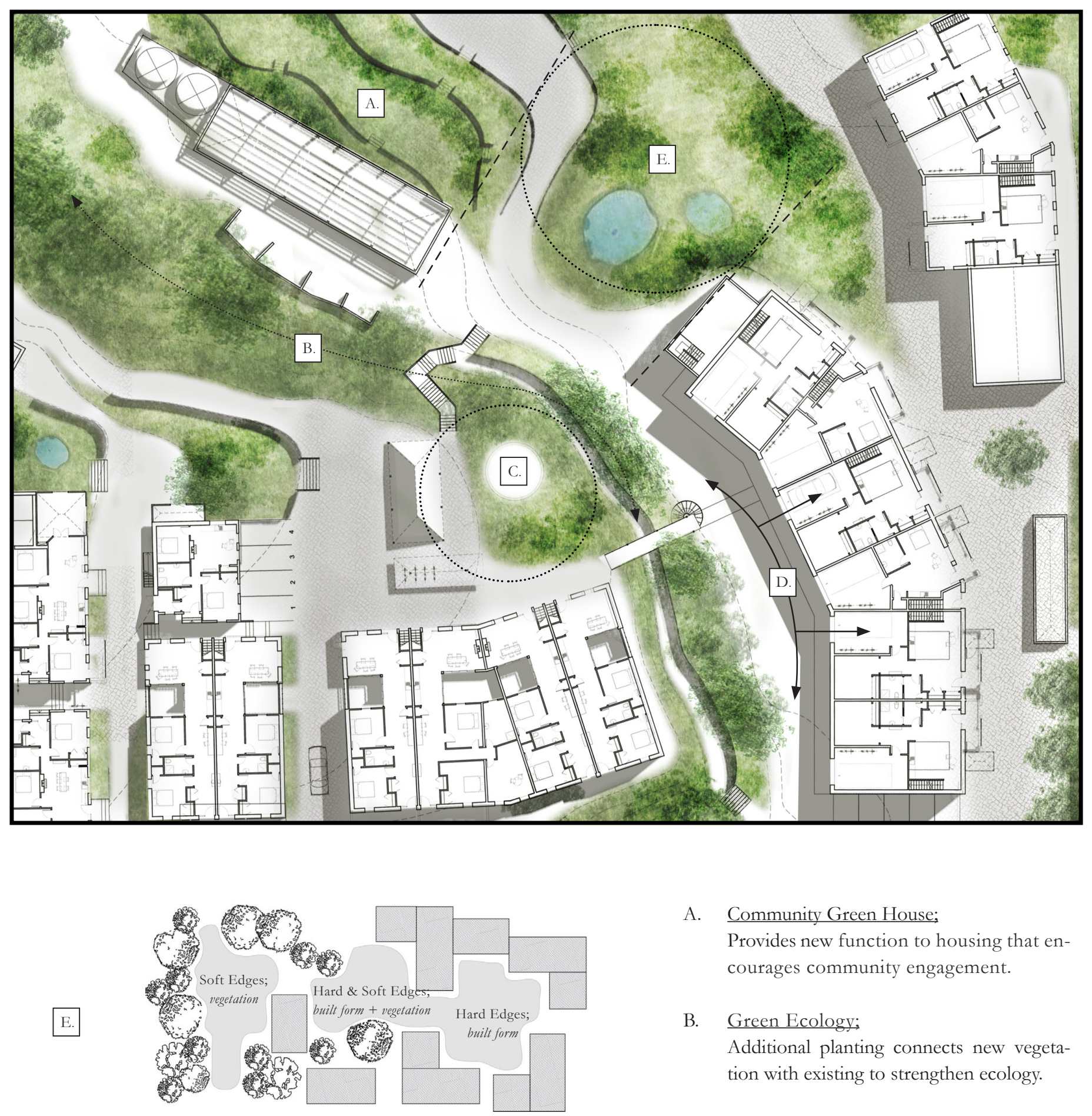

A. Community Green House;

Provides new function to housing that encourages community engagement.

B. Green Ecology;

Additional planting connects new vegetation with existing to strengthen ecology.

C. Community Park;

Located on plateau, defined by built form.

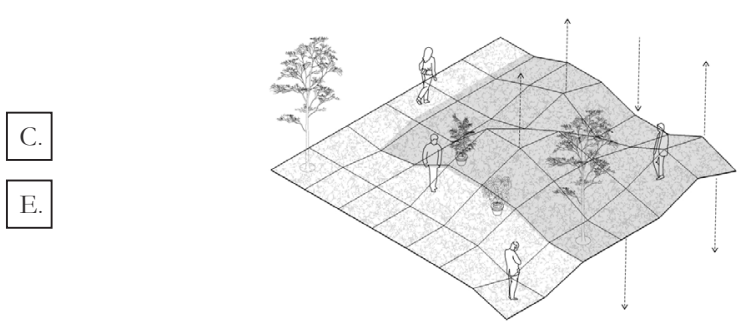

D. Vehicle Parking;

Garages accessed from shared road

E. Main Garden;

Links hydrology with rain water gardens and open public green space. The largest open space contrasts in scale to other pocket parks and terraced gardens. 


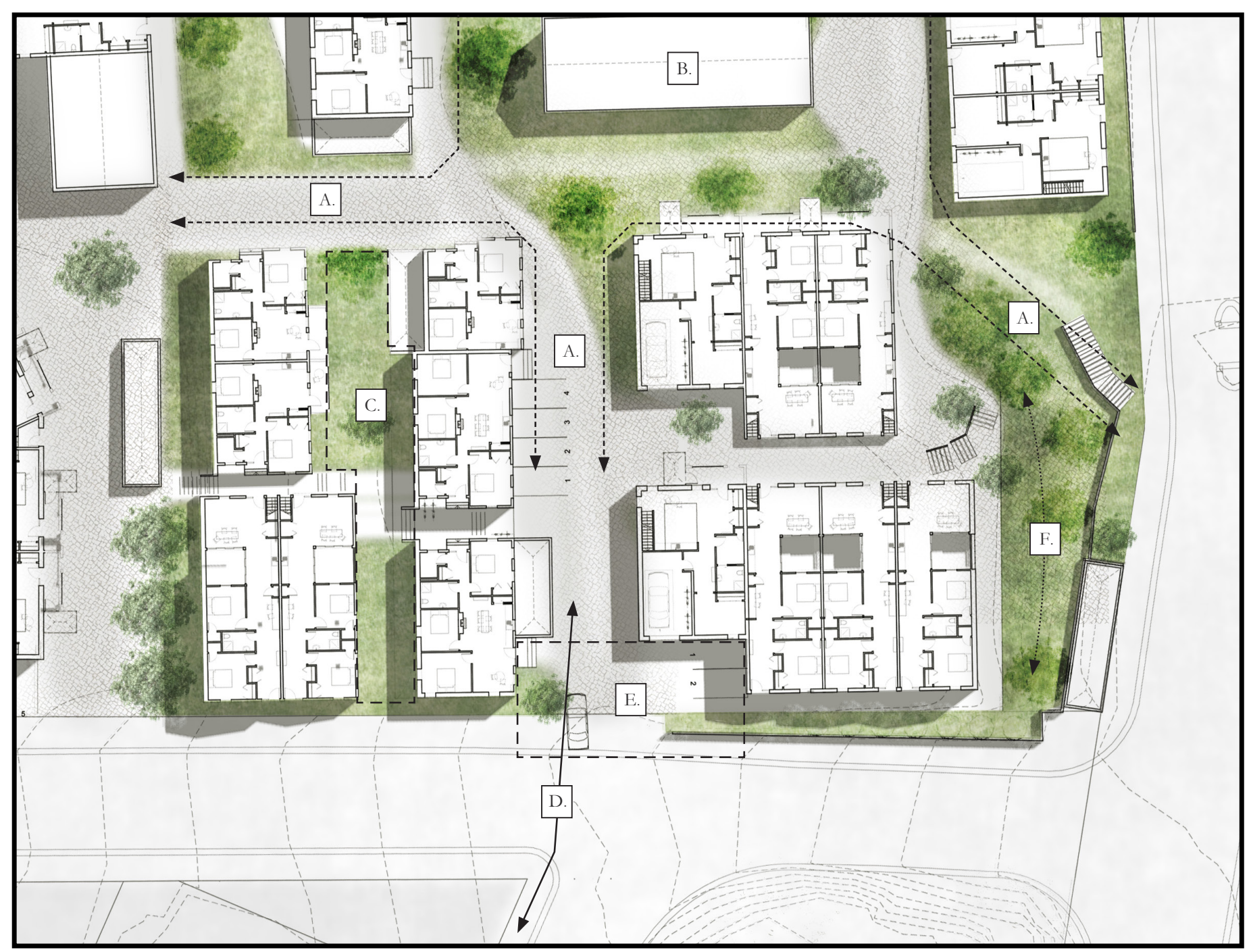

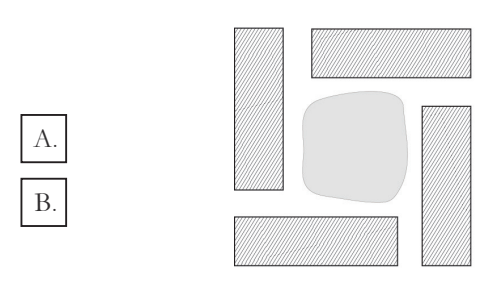

Static Space; courtyard, plaza, foyer, square
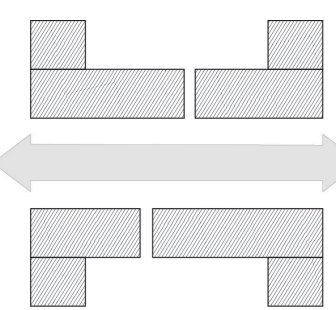

Moving Space; street, pathway, stairs, road

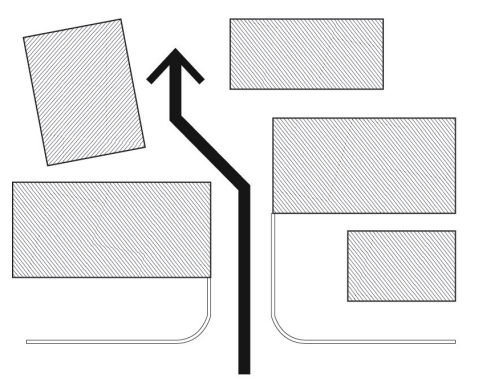

A. Moving Space;

Narrow, green corridors through site

B. Static Space;

Larger courtyard for people to occupy

C. Private Gardens;

Seperated from public realm.

D. Street continuity;

Resident parking located at perimeter

E. Wider street entrance;

Permeable entry encouraging pedestrians

F. New Vegetation;

Plants strengthen steep topography and provide privacy from street. 


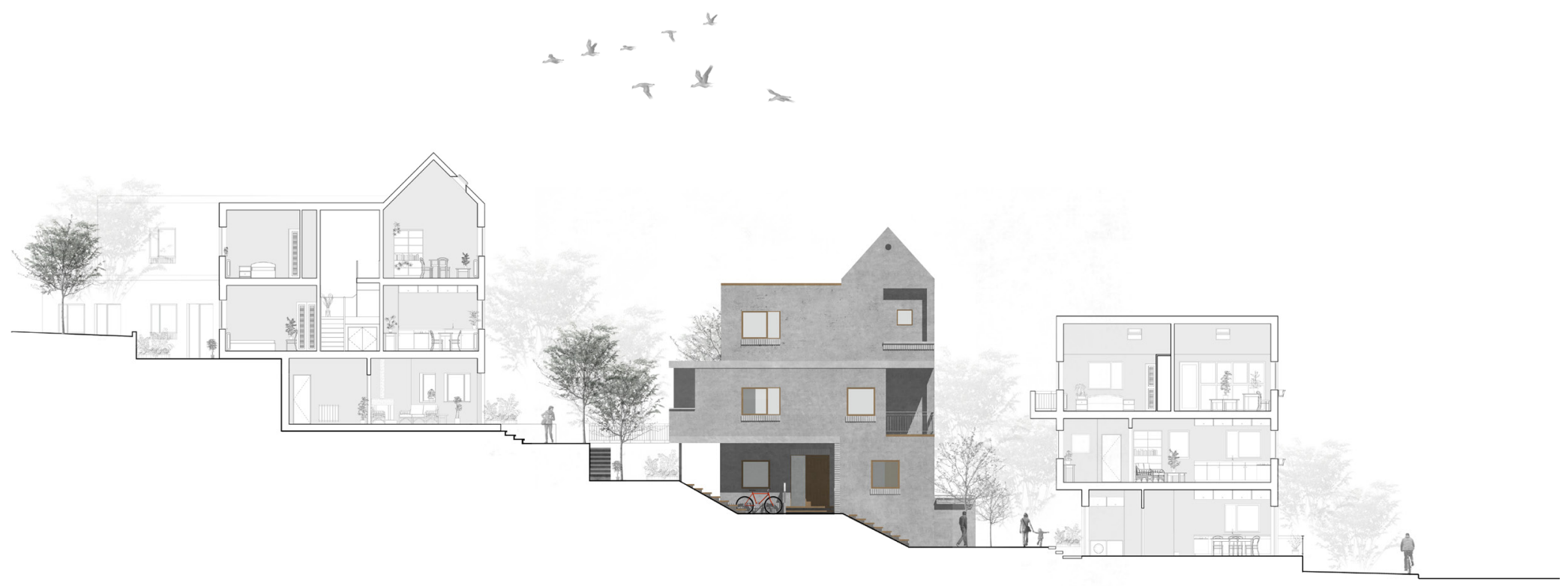




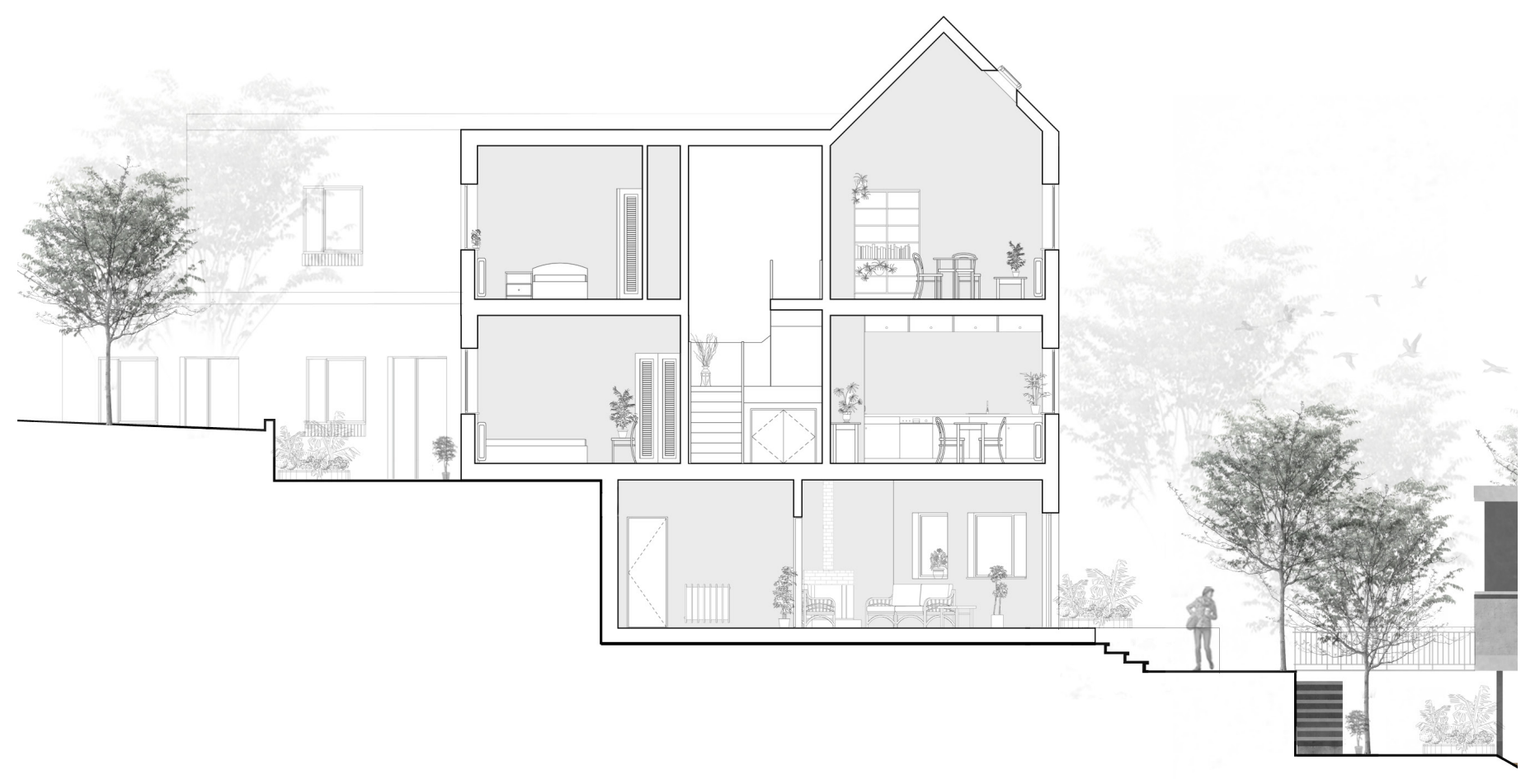




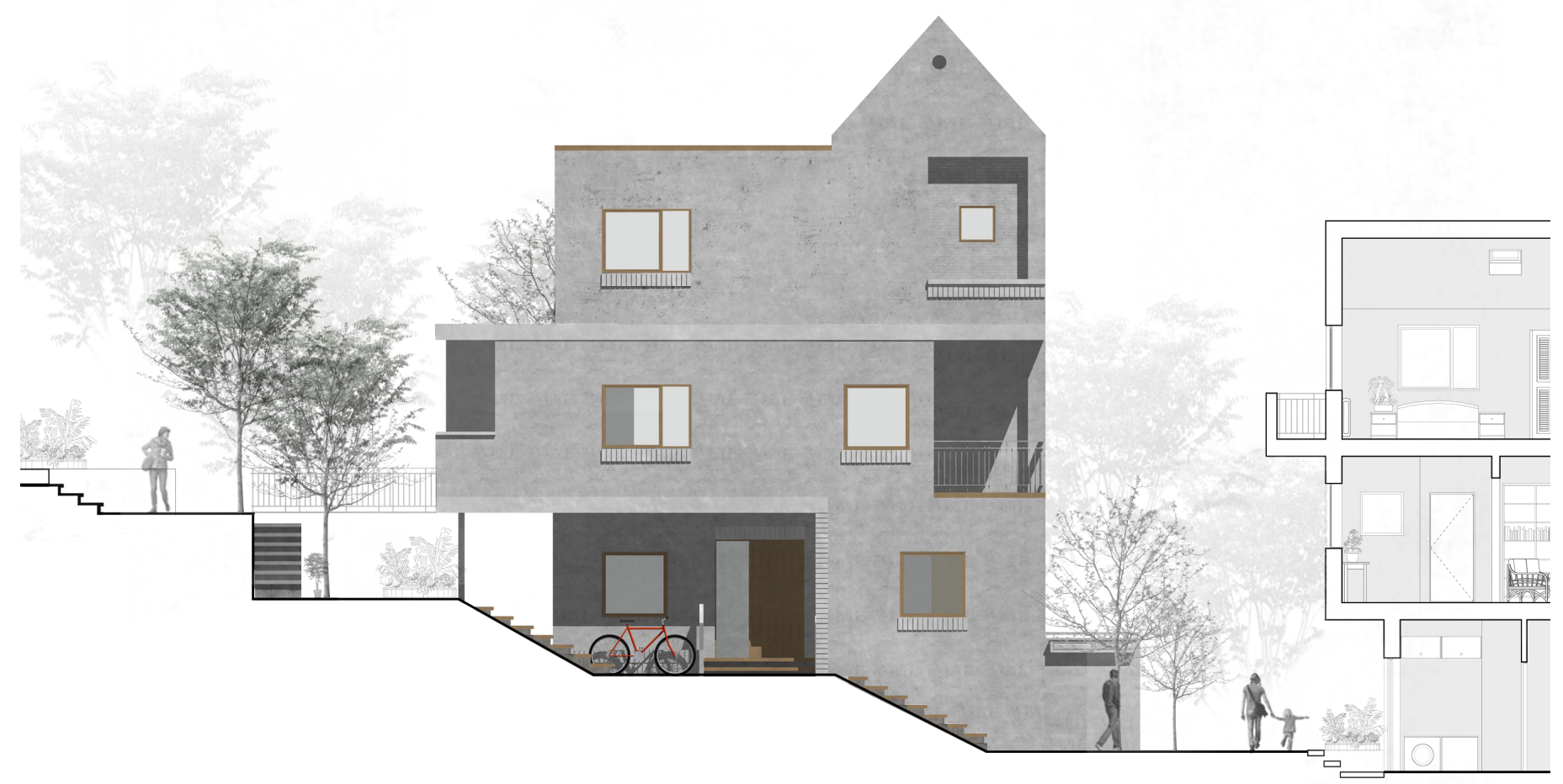




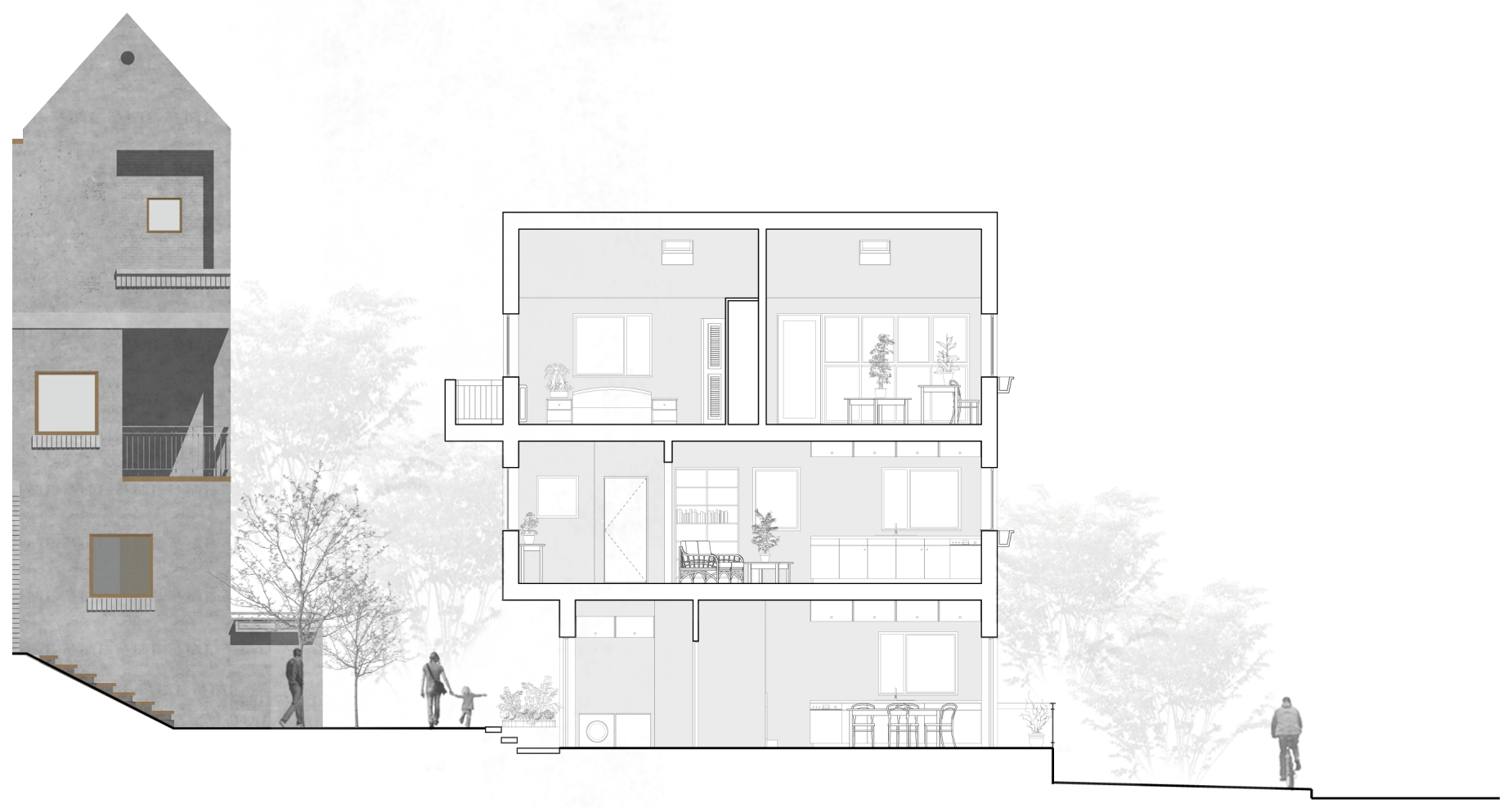




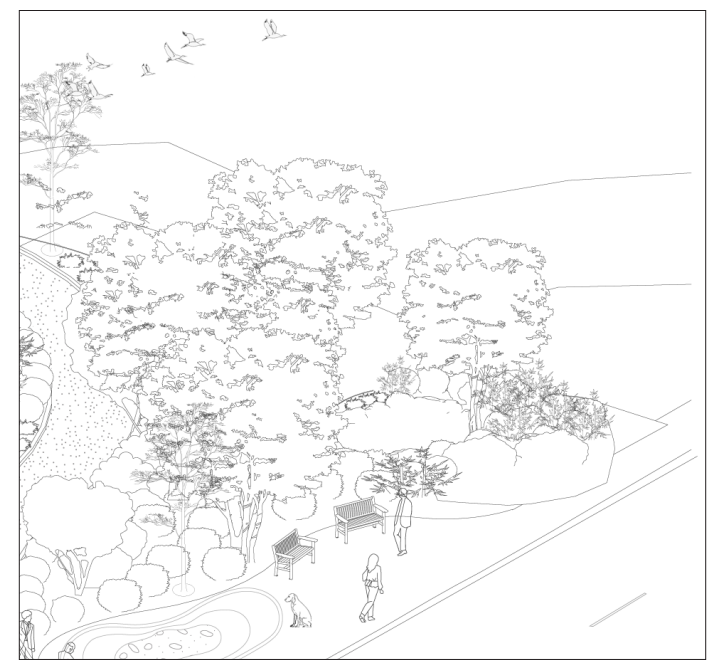

Green Ecology;

Vegetation integrates with public spaces providing soft edge to hard streetscape.

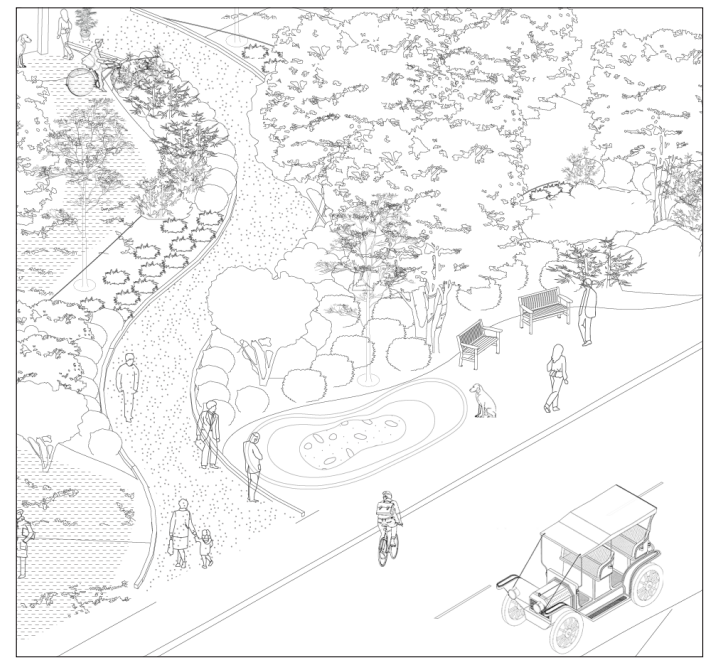

Grey \& Blue

\section{Ecology;}

Street edge widens to create entry. Rain gardens use stormwater and link paths.

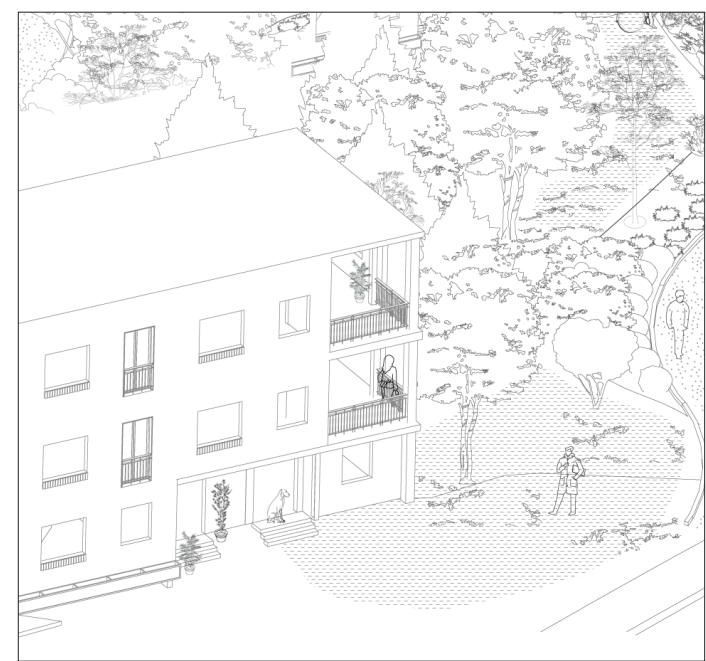

Built Form;

Housing is arranged around site vegetation. Front yards create buffer to street. 


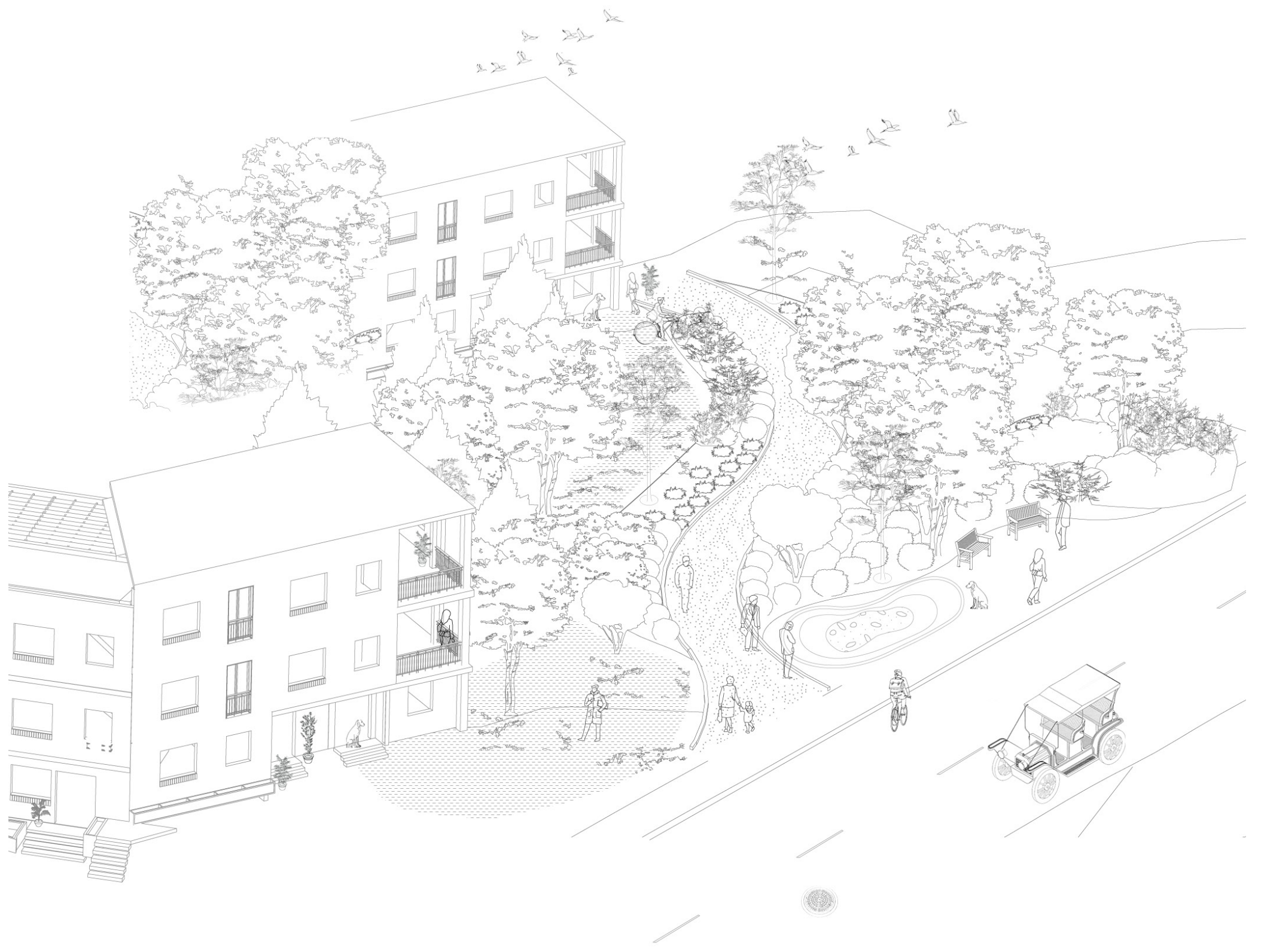




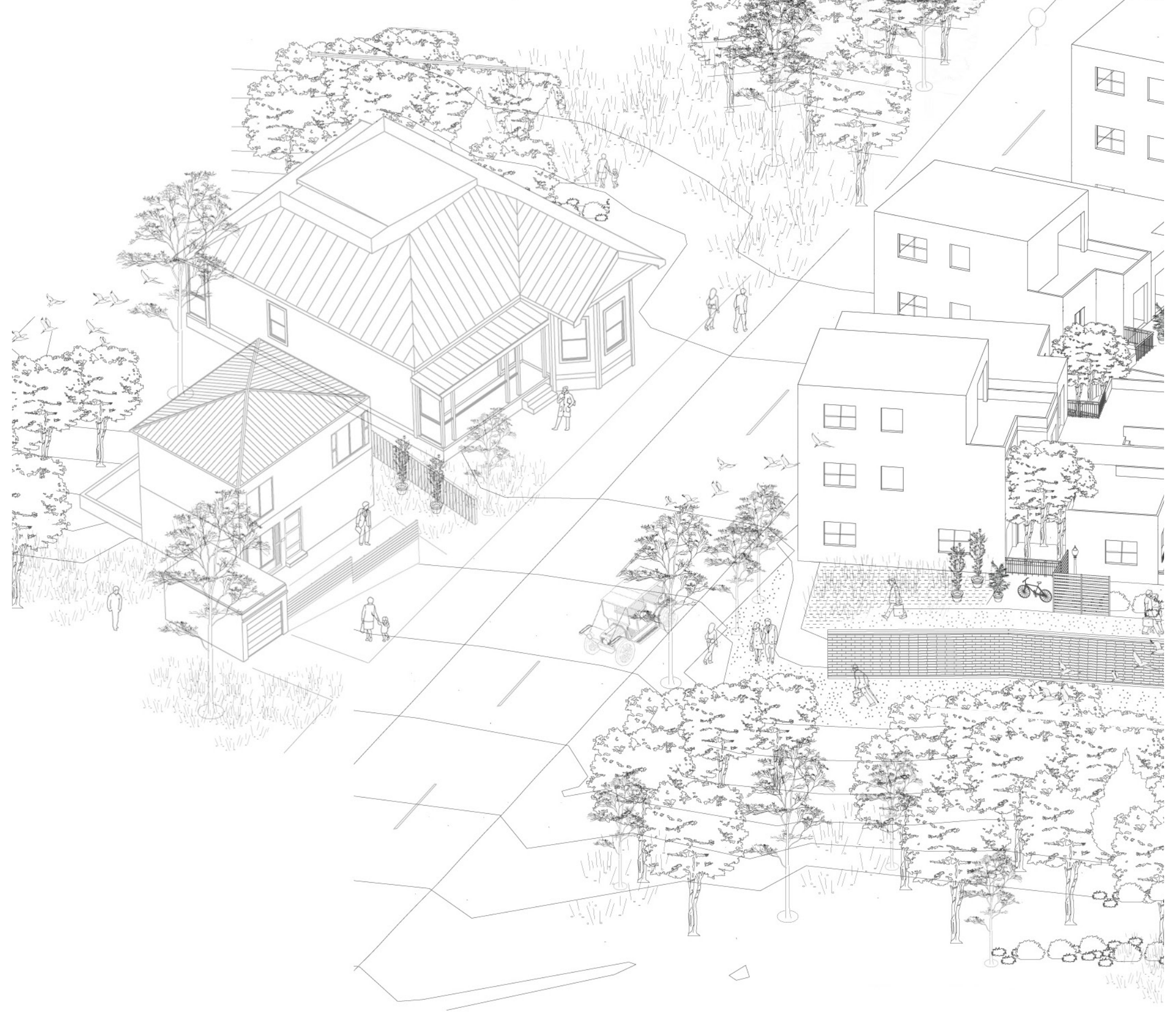




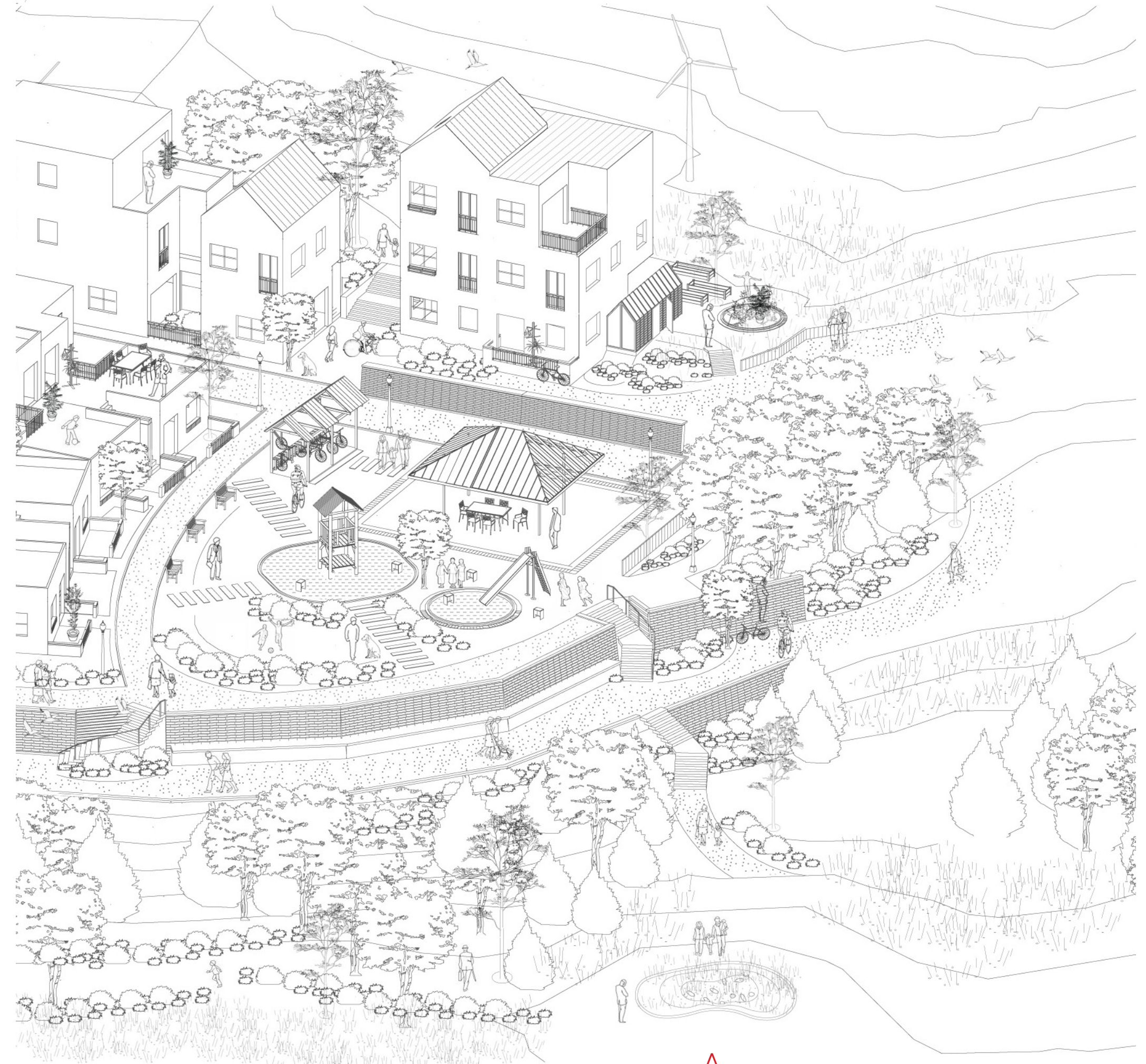



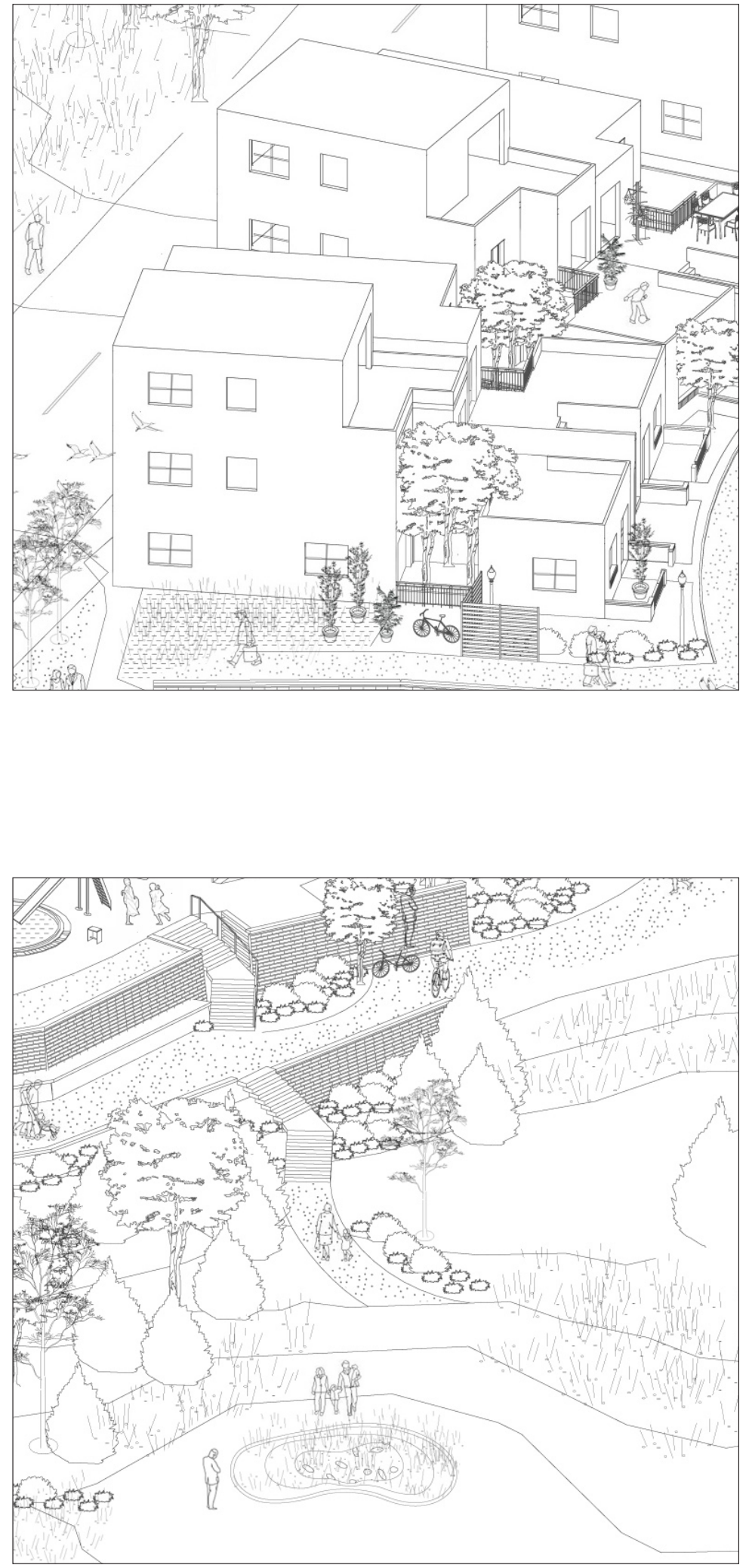

Housing;

Height defines street edge while stepping down towards public park for engagment.
Rainwater Garden; Linking natural flow of water with topography to create ecological public spaces. 


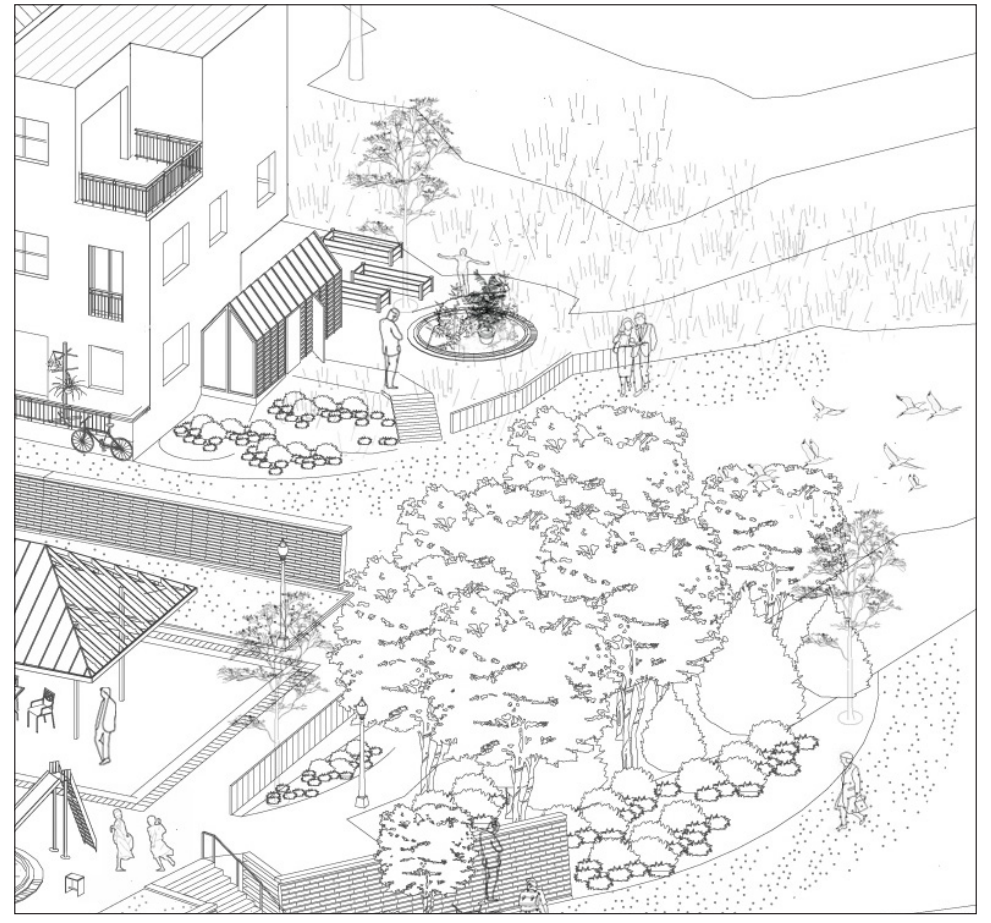

$\underline{\text { Semi Private }}$

Garden;

Terraced landscape defines above and below creating privacy for higher spaces.

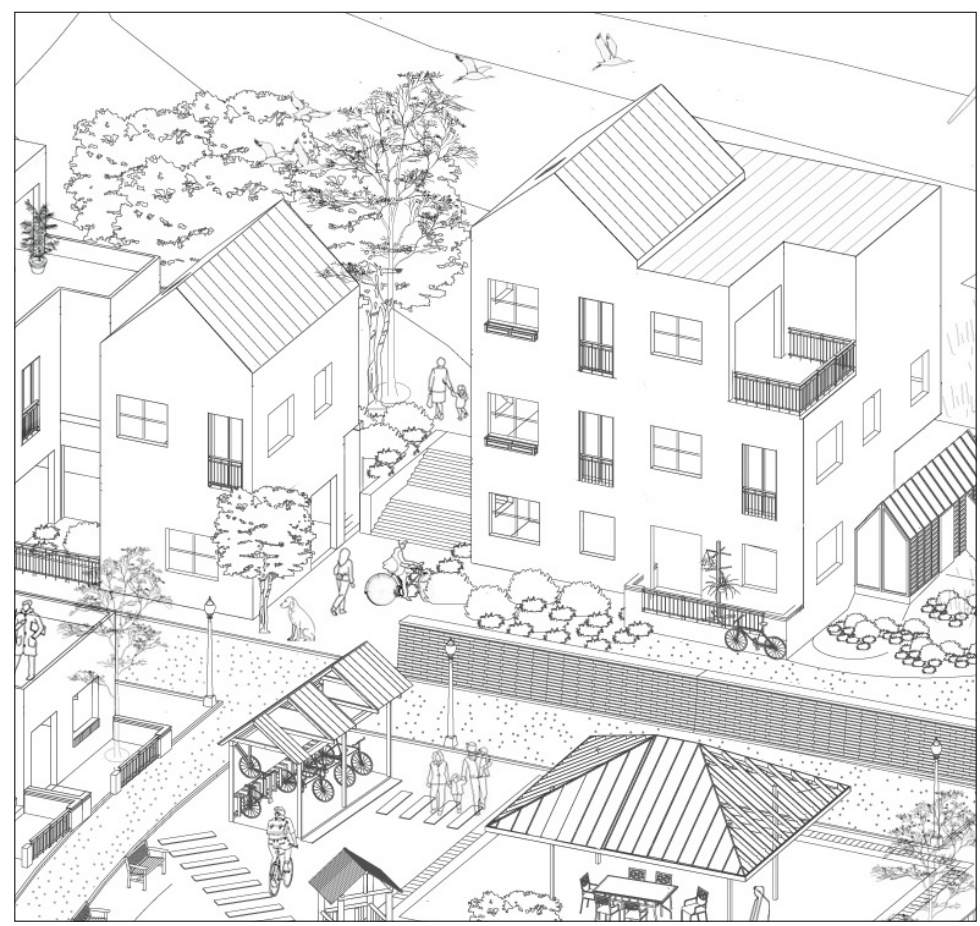

Housing Types;

Various types responding to different slopes. Vertical circulation between. 


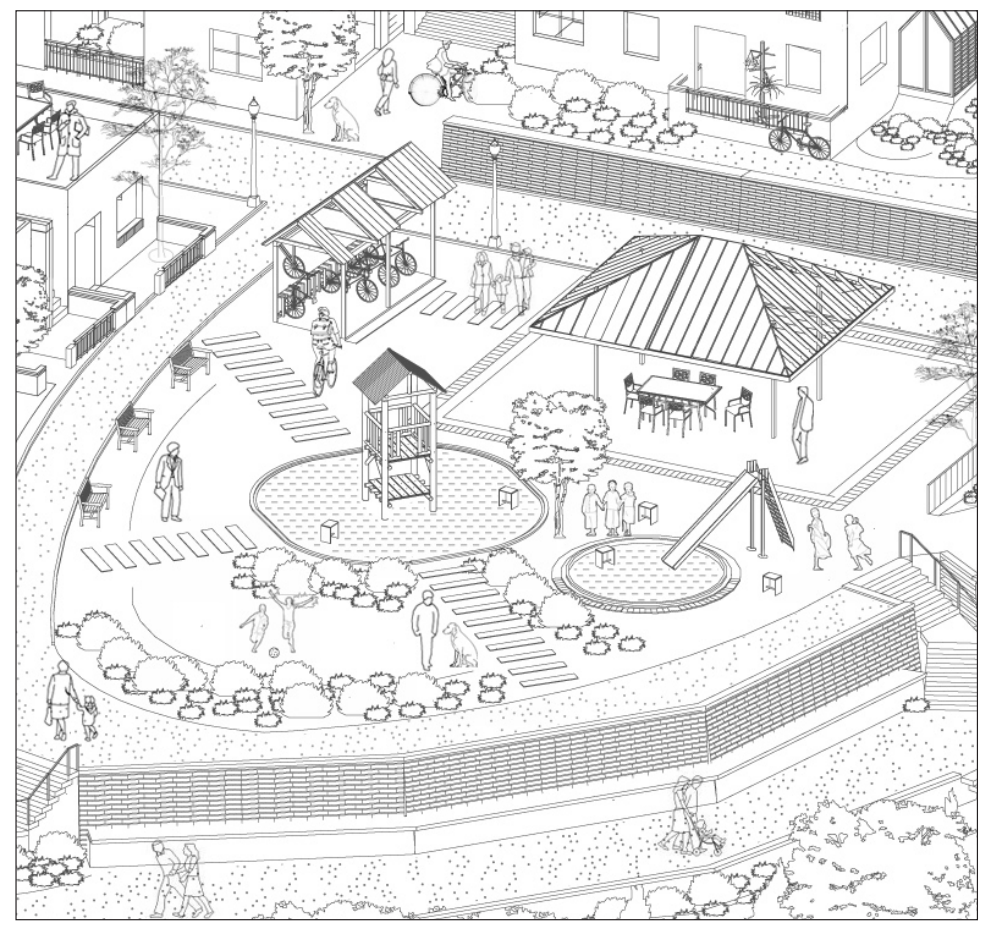

Community Park; Engaging spaces for all to use. Pocket parks are located on plataeus in landscape

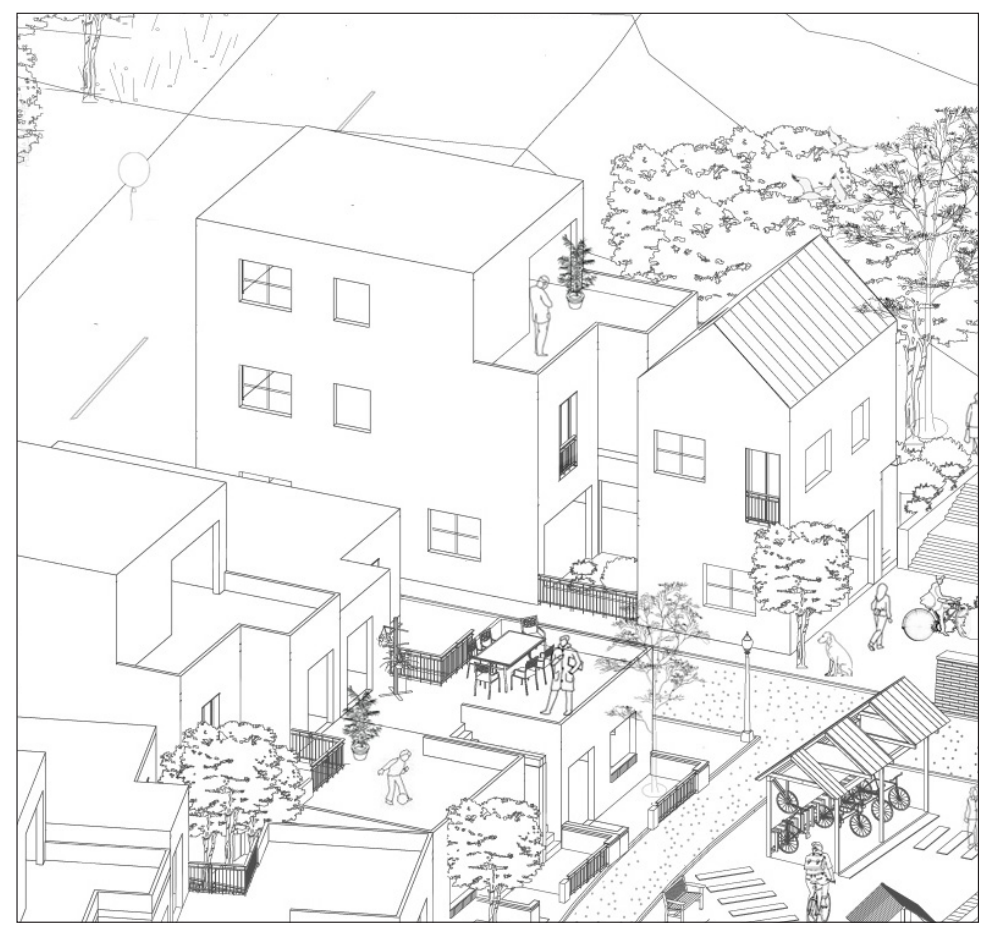

Shared Road;

Provides access for cars and pedestrians off main street. 

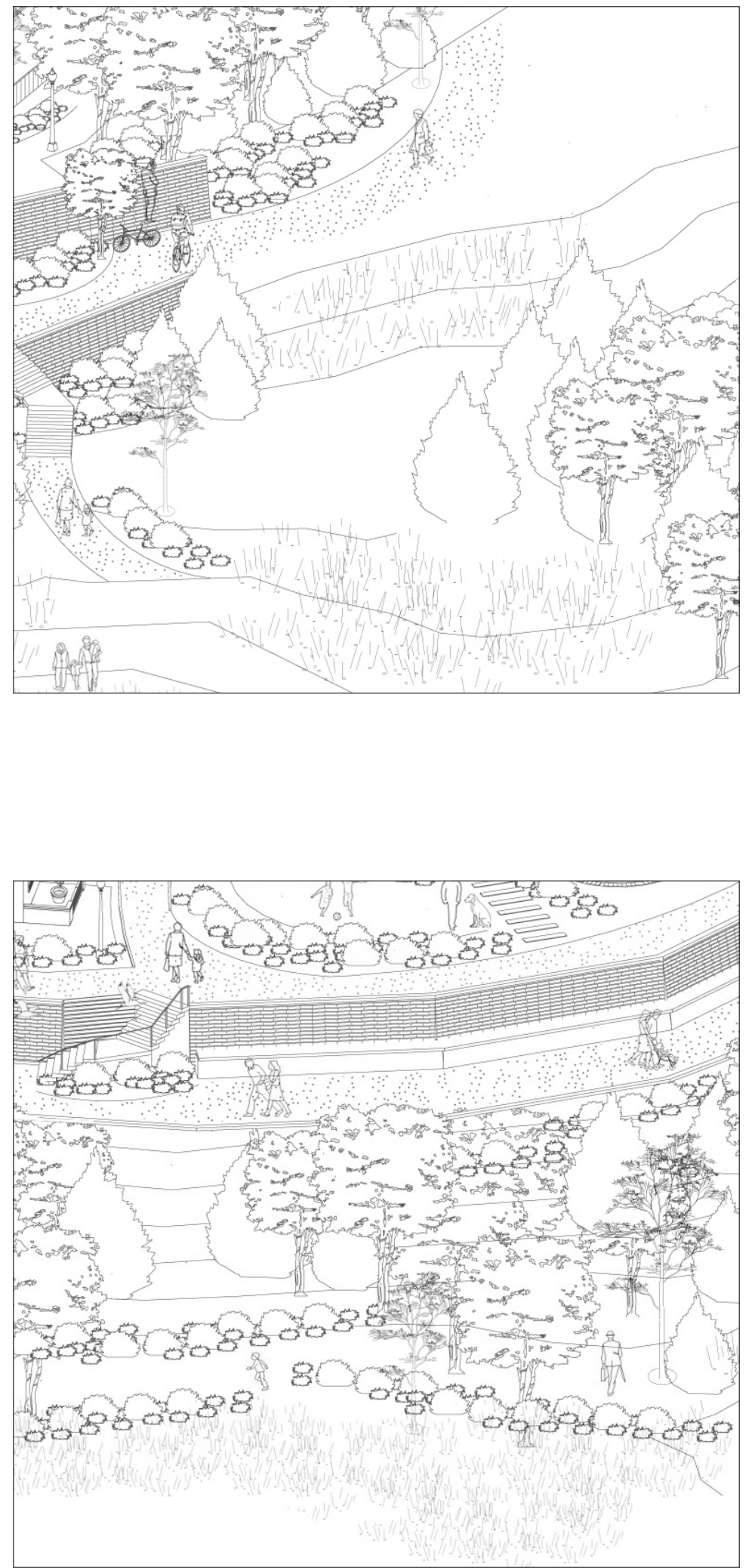

Natural Landscape;

Preserving natural land forms and clearings that provide views across the site

Ecological Paths;

Paths integrated with topography to connect along natural landforms. 


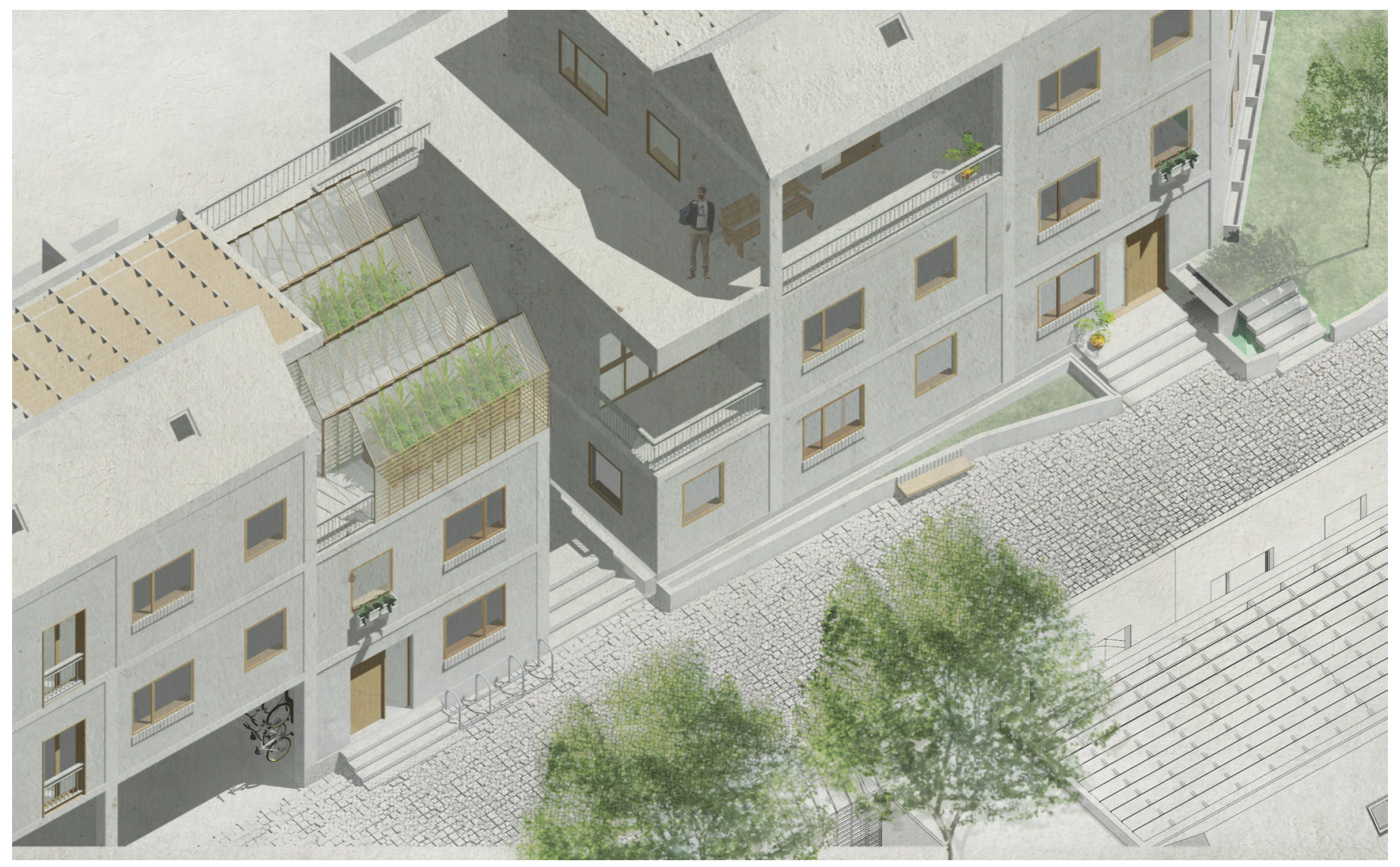

Figure 110 // Axonometric; shared road with housing and bikes 


\section{CONCLUSION}

\section{N S UMMARY}

The research \& design addressed how the arrangement of higher density housing on sloping sites can enhance the public realm, support street activity and integrate with natural ecologies. The project developed through iterative research and design phases and explored specific concepts relevant to achieve the research question and scope.

In this thesis, the research acknowledged mutually dependent components of urban design. The components were applied to the thesis as a design process to develop ideas and findings of new arrangements of built form on sloped sites that integrate housing, ecology, the street and the broader public realm. The end goal was to provide opportunities for densification of an urban site that improved the quality of the public and private realm and environmental ecology for urban dwellers.

\section{R I T I C A L R E F L E C T I N}

As the research and design process progressed the importance of considering multiple components contributing to the urban environment became evident. Main urban components covered were; housing densification, relationship between built form and topography, defining territory and privacy of public realm, and strengthening natural ecology networks. All four components started as individual concepts that developed throughout the research and design process. The development led to strategies and opportunities that were not recognized at the early phases of the project. The most successful moments in the process came from testing research objectives and determining key learning as to how a component could provide beneficial opportunity to the final and combined design.

This study of urban housing densification, specific to Wellington, was seen as a way to improve upon the current formalities of how the city has subdivided its residential allotments around the city's town belt. Acknowledged prior, the vegetated ridge around the city has compelling landforms and unique natural ecologies that are not reflected in the current arrangement of built form. This evaluation combined with the forecasted growth in suburban and inner city areas encouraged the design process to formulate a response that complimented the city by adding quality public and private space and vitality to residential areas while positively allowing for a denser shift in population. To achieve the result, emphasis was placed equally on components stemming from both built form and landscape. The final design consolidates with both disciplines to create a strategy specific to Wellington yet influential from various literature and precedent projects.

Derived design principles and learning from the theoretical framework were carried throughout 
the process and ensured conclusions in the final stages would reflect that of initial goals and standards.

Increasing dwelling density met the initial goals for consolidation in an urban environment. The existing site had a total of 100 dwellings, measuring $42 \mathrm{dph}$. To introduce more dwellings with increased public space a densification of $175 \%$ dwellings was tested and considered a functional increase. This amount allowed for a balance between the built form and landscape components, both required to achieve consolidation goals for this project. The final net density reached an improvement of $160 \%$, measuring $65 \mathrm{dph}$. This was attained by creating smaller sized attached dwellings in closer vicinity to one another with typologies that better aligned with the various sloping landform. Findings for not reaching the desired $175 \%$ increase in dwellings are as follows;

o reductions caused by removing attached housing to preserve ecology networks and public spaces

o underestimated additional planting to improve natural green network ecology to desired level

o main streets were made wider to function as shared roads

o council apartments measuring $108 \mathrm{dph}$ increased the site's initial net density

A high level of recreational activity was achieved. Throughout the process topography influenced street connections and location of newly organized public spaces. In the final design, flatter plateaus in the topography functioned as permeable pocket parks that pedestrians pass through or oc- cupy. Further research into the topography component led to discoveries in associating housing typologies with the variation of sloping gradients. This achieved dwellings that could strategically occupy a desired slope to be accessed from both upper and lower levels - connecting well to street networks while reducing excavation of the land.

Natural Ecologies met the initial goals and design standards set at the start of the project. Integrating ecological networks into public and shared spaces resulted in quality open green space for residents despite living in a more densely populated urban environment. Ecologies of vegetation, hydrology, and street connectivity were discovered as prominent networks associated to the urban town belt location and topography. The integration of this was vital as access to urban green space is essential for the quality of life experienced by urban dwellers and promotes social cohesion, physical and psychological well being (Bird 2004) - important for people living in denser environments.

\section{O N C L U D I G C O M M E T T}

The analysis of urban components specific to the selected Rolleston Street site can be applied to wider residential slopes in the city that are in close vicinity to the city's town belt. Based on the Site and Context analysis of the city, conducted in Chapter Three, suburbs with similar geography and urban environments include Mt Victoria, Kelburn, Aro Valley and areas of Newtown. The research could also be applied to these areas as a system for establishing improved liveability in denser housing environments. 
THESIS REFERENCES 
Abbott, Derek., and Kimball Pollit. Hill Housing : A Guide to Design and Construction. Derek Abbott and Kimball Pollit. New York: Whitney Library of Design, 1981. Print.

Aldallal, Enis, Husam Al Waer, and Soumyen Bandyopadhyay. Site and Composition : Design Strategies in Architecture and Urbanism. Enis Aldallal, Husam AlWaer and Soumen Bandyopadyay. 2016. Print.

Arendt, Randall. Envisioning Better Communities : Seeing More Options, Making Wiser Choices. Randall Arendt. Chicago, IL : Washington, D.C.: American Planning Association, Planners ; Urban Land Institute, 2010. Print.

Beatley, Timothy. Biophilic Cities : Integrating Nature into Urban Design and Planning. Washington, DC: Island, 2011. Web.

Bertram, Nigel. and Kim. Halik. Division and Multiplication : Building and Inhabitation in Inner Melbourne. Nigel Bertram, Kim Halik. Melbourne: RMIT, 2002. Print.
Betanzo, Mike. Pros and Cons of High Density Urban Environments. Urban Design School of Architecture. 2007. Web

Bradshaw, and Bekoff. Integrating Humans and Nature: Reconciling the Boundaries of Science and Society. Trends in Ecology \& Evolution 15.8 (2000): 309-10. Web.

Brophy, Vivienne., and J. Owen. Lewis. $A$ Green Vitruvius : Principles and Practice of Sustainable Architectural Design. Vivienne Brophy and J. Owen Lewis. 2nd ed. London ; Washington, DC: Earthscan, 2011. Print.

Coyle, Stephen., Andres. Duany, and Ebrary, Inc. Sustainable and Resilient Communities : $A$ Comprehensive Action Plan for Towns, Cities, and Regions. edited by Stephen. 2011. Web.

Design and Management of Sustainable Built Environments. Edited by Yao, Runming. London: Springer, 2013. Print. 
Duany, Andres., Jeff. Speck, and Mike. Lydon. The Smart Growth Manual. Andres Duany, Jeff Speck with Mike Lydon. New York: McGrawHill, 2010. Print.

Friedman, Avi, and Ebrary, Inc. Fundamentals of Sustainable Dwellings. Avi Friedman. Washington, DC: Island, 2012. Web.

Gaston, Kevin J. Urban Ecology. Edited by Kevin J. Gaston. Cambridge ; New York: Cambridge UP, 2010. Print. Ecological Reviews.

Golany, Gideon., and Toshio Ojima. Geospace Urban Design. Gideon S. Golany, Toshio Ojima. New York: John Wiley, 1996. Print.

Gehl, Jan. Life between Buildings : Using Public Space. Jan Gehl ; Translated by Jo Koch. Washington, DC: Island, 2011. Print.
Gehl, Jan. Cities for People. Jan Gehl. Washington, DC: Island, 2010. Print.

Gehl, Jan, and Lars Gemzøe. New City Spaces. Jan Gehl \& Lars Gemzøe. 3rd ed. Copenhagen: Danish Architectural, 2003. Print.

Greater London Council. Dept. of Architecture Civic Design. An Introduction to Housing Layout: A GLC Study. USA ed. London : New York: Architectural ; Nichols Pub., 1978. Print.

Hertzberger, Herman. Space and the Architect: Lessons in Architecture 2. Herman Hertzberger. Rotterdam: 010, 2000. Print.

Konijnendijk, Cecil. Urban Forests and Trees $A$ Reference Book. Edited by Cecil Konijnendijk, Kjell Nilsson, Thomas Randrup, Jasper Schipperijn. Berlin, Heidelberg: SpringerVerlag Berlin Heidelberg, 2005. Web. 
Levitt, David. The Housing Design Handbook: A Guide to Good Practice. David Levitt. London ; New York: Routledge, 2010. Print.

Lynch, Kevin. Good City Form. Kevin Lynch. Cambridge, Mass.: MIT, 1984. Print.

Marselle, M., S. Warber, and K. Irvine. Natural Health Service: Enhancing Wellbeing with Group Walks in Green Spaces. BMC Complementary and Alternative Medicine, 2012, Vol.12(Suppl 1). Web.

Neutra, Richard Joseph. World and Dwelling. Richard Neutra. London: A. Tiranti, 1962. Print.

New Zealand. Census Statistics Office. Statistical Report on the Population of the Dominion of New Zealand for the Year. Compiled in the Census and Statistics Office, Wellington. Print.

Opher, Philip, and Clinton. Bird. Architecture and Urban Design in Six British New Towns. Philip Opher, Clinton Bird. Headington, Oxfordshire : Urban Design, Oxford Polytechnic, 1981. Print.
Sanoff, Henry. Designing with Community Participation. Edited by Henry Sanoff. Stroudsburg, Pa.: Dowden, Hutchinson \& Ross, 1978.

Print.

Selman, Paul H. Planning at the Landscape Scale. Paul Selman. London: Routledge, 2005. Print.

Schantz, Peter, and Erik Stigell. A Criterion Method for Measuring Route Distance in Physically Active Commuting. Medicine and Science in Sports and Exercise 41.2 (2009): 472-8. Web.

Wellington City Council. Proposed District Plan for Wellington City. Wellington City Council. Wellington, (N.Z.): Wellington City Council, 1994. Print.

Yosef Rafeq Jabareen. Sustainable Urban Forms: Their Typologies, Models, and Concepts. Journal of Planning Education and Research 26.1 (2006): 38-52. Web. 
Figure 1

Wellington; town belt ridgeline \& city https://sporemould.wordpress.com

Figure 2

Wellington aerial; town belt ridges

Figure 3

1:200 massing model; linking topography, built form, street connections

Figure 4

Norrebro Solund Homes; facades

$<$ https://tredjentur.dk/upload.com>

Figure 5

Norrebro Solund Homes; site plan with ecologies labelled

<https://tredjentur.dk/upload.com>

Figure 6

Norrebro Solund Homes; hydrology and vegetation ecology

$<$ https://tredjentur.dk/upload.com>

Figure 7

Norrebro Solund Homes: street axonometric $<$ https://tredjentur.dk/upload.com>

Figure 8

Norrebro Solund Homes: embankment axonometric

<https://tredjentur.dk/upload.com>

Figure 9

Norrebro Solund Homes: workshop axonometric <https://tredjentur.dk/upload.com>

Figure 10

Norrebro Solund Homes: park axonometric $<$ https://tredjentur.dk/upload.com>ᄀ

Figure 11

Springhill; housing and water basin

Figure 12

Springhill; site plan with labelled water ecology

Figure 13

Springhill; illustration of retaining wall

Figure 14

Springhill; illustration of rill

Figure 15

Springhill; front elevation photo

$<$ http://www.architype.co.uk/project/springhill-co-housing/>

Figure 16

Springhill; public and private street section

Figure 17

Springhill; section sketch water basin and play space

Figure 18

Springhill; internal street view $<$ http://www.architype.co.uk/project/springhill-co-housing/> 
Figure 19

Siedlung Halen; roof bridge and stairwell

$<$ http://housingprototypes.org/>

Figure 20

Siedlung Halen; urban stairwell

$<$ http://housingprototypes.org/>

Figure 21

Siedlung Halen; long sectional drawing

$<$ http://housingprototypes.org/>

Figure 22

Siedlung Halen; short sectional drawing

$<$ http://housingprototypes.org/>

Figure 23

Siedlung Halen; site plan

$<$ http://housingprototypes.org/>

Figure 24

Siedlung Halen; concept diagram of dual access to dwelling

\section{Figure 25}

Donnybrook Quarter; courtyard photo Architizer <http://architizer.com/projects/ donnybrook-quarter/>

Figure 26

Donnybrook Quarter; site plan and street connections

Architizer <http://architizer.com/projects/ donnybrook-quarter/>

Figure 27

Donnybrook Quarter; communal 7m wide street

Architizer < http://architizer.com/projects/ donnybrook-quarter/>

Figure 28

Donnybrook Quarter; street width to building height proportion

Architizer < http://architizer.com/projects/ donnybrook-quarter/>

Figure 29

Donnybrook Quarter; pedestrian movement patterns

Architizer <http://architizer.com/projects/ donnybrook-quarter/>

Figure 30

Donnybrook Quarter; notched terrace form and light penetration

Figure 31

Diagram; design process

Figure 32

Axonometric; wellington city buildings, topography, town belt

Figure 33

Wellington aerial; context map

Figure 34

Wellington aerial; suburb population map

Figure 35

Wellington aerial; city circulation map 
Figure 36

Wellington aerial; town belt amenity map

Figure 37

Wellington aerial; GIS contour slope maps

Figure 38

Wellington aerial; determined site

Figure 39

Wellington aerial; town belt context

Figure 40

1:200 model; experimentation of density

Figure 41

Dwelling Density Type; Rolleston Street apartments

Figure 42

Dwelling Density Type; One Storey House

Figure 43

Dwelling Density Type; Two Storey House

Figure 44

Dwelling Density Type; Two Storey House

(2)

Figure 45

Density Type Axonometric; One Storey

Figure 46

Density Type Axonometric; Two Storey

Figure 47

Density Type Axonometric; Rolleston Street
Apartments

Figure 48

Density Type Axonometric; site coverage

Figure 49

Site Plan; dwelling and density map

Figure 50

1:500 model; site contours

Figure 51

Wellington aerial; site location in city

Figure 52

Diagram; locating section cuts

Figure 53

Iso Models; site slope sections

Figure 54

Slope Chart; classifying slope gradients

Figure 55

Site aerial; slope gradient map

Figure 56

Site Long Section; Rolleston Street

Figure 57

Terrace Inventory; Argyle Street

Bertram, Nigel. and Kim. Halik. Division and Multiplication : Building and Inhabitation in Inner Melbourne.

Figure 58

Terrace Inventory; design handbook type B 
Levitt, David. The Housing Design Handbook: A Guide to Good Practice.

Figure 59

Terrace Inventory; design handbook type G Levitt, David. The Housing Design Handbook: A Guide to Good Practice.

Figure 60

Terrace Inventory; Park Street Abbotsford Bertram, Nigel. and Kim. Halik. Division and Multiplication : Building and Inhabitation in Inner Melbourne.

Figure 61

Terrace Inventory; design handbook type F Levitt, David. The Housing Design Handbook : A Guide to Good Practice.

Figure 62

Terrace Inventory; Drummond Street, Carlton

Bertram, Nigel. and Kim. Halik. Division and Multiplication : Building and Inhabitation in Inner Melbourne.

Figure 63

Terrace Inventory; Paddington Terrace

Bertram, Nigel. and Kim. Halik. Division and Multiplication : Building and Inhabitation in Inner Melbourne.

Figure 64

Terrace Inventory; Grattan Street, Carlton Bertram, Nigel. and Kim. Halik. Division and Multiplication : Building and Inhabitation in Inner Melbourne.
Figure 65

Terrace Inventory; Michael Street, Clifton Hill

Bertram, Nigel. and Kim. Halik. Division and Multiplication : Building and Inhabitation in Inner Melbourne.

Figure 66

Terrace Inventory; Langdon Gills, Essex Abbott, Derek., and Kimball Pollit. Hill Housing : A Guide to Design and Construction.

Figure 67

Terrace Inventory; Duke Street, Three Kings Abbott, Derek., and Kimball Pollit. Hill Housing : A Guide to Design and Construction.

Figure 68

Terrace Inventory; Peckarmans Wood, Dulwich

Abbott, Derek., and Kimball Pollit. Hill Housing : A Guide to Design and Construction.

Figure 69

Terrace Inventory; Beetham Cumbria Abbott, Derek., and Kimball Pollit. Hill Housing : A Guide to Design and Construction.

Figure 70

Terrace Inventory; Siedlung Halen $<$ http://housingprototypes.org/> Figure 71

Section; built form and topography explora- 
tion

Figure 72

Axonometric; layering the landscape

Figure 73

Iso Section; layering landscape with built

form

Figure 74

Aerial Perspective; early iteration of massing on slope

Figure 75

Diagram; Jan Gehl's degree of privacy

Gehl, Jan. Life between Buildings : Using

Public Space.

Figure 76-86

London Mews \& Terrace Photos

Greater London Council. Dept. of Architecture Civic Design. An Introduction to Housing Layout

Figure 87

Ecology Axonometric; grey street networks

Figure 88

Ecology Axonometric; green vegetation networks

Figure 89

Ecology Axonometric; blue hydrology networks

Figure 90

Ecology Site Map; green networks
Figure 91

Ecology Site Map; blue networks

Figure 92

Ecology Sketch; blue and green combined networks

Figure 93

Ecology Site Map; grey networks

Figure 94

1:200 Model; site circulation iterative process

Figure 95

Site Aerial; iteration of built form and ecologies

Figure 96

Diagram; blue, green, grey ecology overlap

Figure 97

Site Plan; final display of housing, landscape and ecology

Figure 98

Site Plan Zoom One; urban design analysis

Figure 99

Site Plan Zoom One; urban design analysis

Figure 100

Site Plan Zoom Two; urban design analysis

Figure 101

Site Plan Zoom Three; urban design analysis 
Figure 103

Site Plan Zoom Four; urban design analysis

Figure 104

Site Section; housing types D and B

Figure 105

Section; terracing dwelling and landscape

Figure 106

Section; through stairwell with semi-private gardens either side

Figure 107

Section; dwelling proportion and scale in relation to site

Figure 108

Axonometric; linking housing and natural ecologies at street edge

Figure 109

Axonometric; final site composition with public and private realm

Figure 110

Axonometric; shared road with housing and bikes 